UNIVERSIDADE DE SÃO PAULO

INSTITUTO DE PSICOLOGIA

\author{
RICARDO TRAPÉ TRINCA
}

O Real nos fatos clínicos psicanalíticos: entre o esquecimento e a sua visitação 
RICARDO TRAPÉ TRINCA

\title{
O Real nos fatos clínicos psicanalíticos: entre o esquecimento e a sua visitação (Versão Original)
}

\author{
Tese apresentada ao Instituto de Psicologia da \\ Universidade de São Paulo como parte dos \\ requisitos para obtenção do título de Doutor em \\ Psicologia. \\ Área de Concentração: Psicologia Clínica \\ Orientador: Prof. Dr. Gilberto Safra
}

São Paulo 
AUTORIZO A REPRODUÇÃO E DIVULGAÇÃO TOTAL OU PARCIAL DESTE TRABALHO, POR QUALQUER MEIO CONVENCIONAL OU ELETRÔNICO, PARA FINS DE ESTUDO E PESQUISA, DESDE QUE CITADA A FONTE.

Catalogação na publicação

Biblioteca Dante Moreira Leite

Instituto de Psicologia da Universidade de São Paulo

Trinca, Ricardo Trapé.

O Real nos fatos clínicos psicanalíticos: entre o esquecimento e a sua visitação / Ricardo Trapé Trinca; orientador Gilberto Safra. -- São Paulo, 2012.

$353 \mathrm{f}$.

Tese (Doutorado - Programa de Pós-Graduação em Psicologia. Área de Concentração: Psicologia Clínica) - Instituto de Psicologia da Universidade de São Paulo.

1. Psicanálise 2. Realidade 3. Fatos clínicos 4. Pensamento onírico 5. Clínica psicanalítica I. Título. 
Nome: Trinca, Ricardo Trapé

Título: O Real nos fatos clínicos psicanalíticos: entre o esquecimento e a sua visitação

Tese apresentada ao Instituto de Psicologia da Universidade de São Paulo como parte dos requisitos para obtenção do título de Doutor em Psicologia.

Área de concentração: Psicologia Clínica.

Aprovado em:

Banca Examinadora

Prof. Dr.

Instituição:

Assinatura:

Prof. Dr.

Instituição:

Assinatura:

Prof. Dr.

Instituição:

Assinatura:

Prof. Dr.

Instituição:

Assinatura:

Prof. Dr.

Instituição:

Assinatura: 


\section{AGRADECIMENTOS}

Inicialmente agradeço ao CNPq pela concessão da bolsa de estudos.

Agradeço ao Prof. Gilberto Safra, pelo impulso inicial de confiança, tão necessário para desenvolver esta escrita, como também por ter me oferecido, sob a forma de um pensar, o prenúncio ou o germe daquilo que haveria de poder desenvolver posteriormente. Além disso, durante todo o nosso percurso, não só me ajudou a respeitar o processo da produção do texto inacabado, de forma paciente e serena, como pôde me ajudar a escutar e a perceber para qual direção a minha própria escrita apontava-me. Sou incrivelmente grato por sua postura, com a qual pude me identificar, admirando-a e reproduzindo-a.

Sou extremamente grato ao Prof. Luis Cláudio Figueiredo, que pôde me ajudar a ver, no exame de qualificação, aqueles aspectos que tendiam a sufocar o texto, bem como a deixar com que uma escrita mais livre, menos "ontificada", pudesse tomar forma e expressão. E a sua pergunta sobre expansão e ruptura ainda ecoa em meus ouvidos, querendo se fazer escrita...

Agradeço muito ao Tales Ab’Sáber, por poder indicar justamente a diferença entre a possibilidade e o impossível, tal como pude nomear posteriormente, o que deu ao meu trabalho uma nova e fundamental compreensão após o exame de qualificação.

Não seria possível deixar de agradecer especialmente ao meu amigo João Rodrigo Oliveira e Silva, aquele que não cessa de não escrever as páginas deste trabalho e que, por isso mesmo, determinou profundamente a concepção e a consecução desta tese, como uma voz silenciosa que o leitor atento poderá, vez ou outra, escutar no palimpsesto das palavras redigidas, como vestígios de uma escrita heterogênea, expressão verdadeira de um trabalho escrito a quatro mãos, com as quais tive o privilégio de trabalhar.

Agradeço também a Luciana, pela amizade, pelas interessantes conversas e pelo truco indescritível... 
Agradeço aos meus irmãos Alexandre e Cristiano, pelas tardes em família, pelas discussões, pelas festas e pelos dias comuns, pois tudo isso criou aquela familiaridade que me devolvia sempre para um mundo ancorado, fraternal e bom.

Agradeço também aos meus queridos sobrinhos Catarina, Rafael e Leonardo, que espalham doçura por minha casa; e ao José e ao Chico, meus 'outros' sobrinhos, também tão queridos, que sempre deixam a casa iluminada de brincadeiras e de futuro...

À Maria Inês e à Francesca, pelas conversas, brincadeiras e 'fofocas' das tardes de domingo, que sempre me retiravam da escrita conhecida para poder voltar à ela renovado...

Agradeço às minhas amigas Silvia e Patrícia. À Silvia, por toda sua ajuda no PROMUD, e pela disposição constante por discutir casos complicados, de modo fácil e inteligente. À Patrícia, por sua presença sempre tão verdadeira e por sua leitura 'emocional' dos casos clínicos, além, é claro, por sua amizade.

À minha amiga Kim, agradeço por sua insistência em Heidegger e na liberdade, e por sua escuta sempre atenciosa.

Ao Maurício e ao Sanches, amigos ausentes, sempre presentes em meu coração, agradeço pela amizade que o tempo não abala.

Ao Claude e à Marie Christine, agradeço por toda a ajuda que me deram nos anos de doutorado, e por toda a paciência que tiveram com um genro às vezes sério demais...

Agradeço ao meu amigo Ronaldo S. Torres, com quem descobri que as diferenças inconciliáveis entre variados autores psicanalíticos - Winnicott, Bion, Lacan... - são suplantadas genuinamente apenas por um gesto de amizade, que permite convergirmos na diferença e, até mesmo, pela diferença.

Agradeço à minha amiga Ana Paula L. Gianesi, com quem experimento a cada conversa, mesmo as mais simples, aquele desconhecido que é próprio dom e movimento de algo surpreendente e indeterminado; um indeterminado que é a fonte, o profundo manancial, de 
qualquer criação e de qualquer possibilidade de nossa vida emocional. Agradeço por sua amizade e presença sempre cálida, sorridente e amorosa, a não ser quando precisava dar umas broncas em todas as crianças que estavam fazendo uma tremenda bagunça...

Agradeço ao meu pai, especialmente por ter me ensinado, entre convergências e divergências, a presenciar e a exercer a liberdade de um pensar que, apenas assim, revela-se para quem o pensa como sua verdade mais sanguínea. E isso é para toda a vida. Nossas diferenças, diante disso, tornam-se apenas notas de rodapé em um texto fundamental. Espero ter recebido e sustentado essa verdadeira herança neste trabalho.

Agradeço à minha mãe, por sua proximidade e por sua distância, por sua palavra e por seu silêncio, mas, principalmente, pela pura transmissão de minha orfandade; a orfandade que apenas um filho profundamente amado pode vir a sentir e, depois, vir a escrever...

Ao Tomás, meu "filhotico", que me enche de orgulho, admiração e amor em cada novo dia. Um amor que não cabe em nenhuma palavra, em nenhum verso, em nenhum agradecimento; é aquilo que não se escreve, mas que também se faz escrito; e, se faz-se escrito tanto assim, é porque procura expressar e dar testemunho daquilo que faz sentido verdadeiramente para nós, como algo essencial.

À minha filhinha, Alice, que, quando ainda nem era menina, revelou-nos que estamos, sem saber, segurando-nos em um tênue fio, nas bordas de uma noite sem fim: quando seus olhos abriram-se inesperadamente, pudemos ver - repletos de surpresa, encanto e horror - a esperança de nossas vidas, instáveis, brotar na terra desolada. Mais ainda, fomos-lhe devotos e tecemos aqueles fios que a seguraram em nossa terra. Assim, nessa devoção, presenciamo-la crescer: nossa Angelus, de Millet!

À Marine, minha querida, com quem desejo tanto, por mirarmos juntos para algo que nossos olhos nem ao certo sabem dizer o que é... e que, embora vejamos, não vemos nada de concreto, senão algo fugidio e que parece ser apenas produzido pelo nosso olhar. Mas com 
essa mirada germinamos, produzimos e cuidamos de nossa terra: uma beleza em nossa vida que somente com a presença do amor poderia acontecer. Esta tese também tem essa nossa marca, pela qual sou grato e sempre serei. 
E quantos poemas nunca cheguei a escrever, e seus refrões misteriosos pairam à minha volta.

Anna Akhmátova

Sou um escultor, um criador de formas. A cada momento dou vida a novos ídolos E derreto-os todos diante de ti. Jalal ud-Din Rumi

Algo está lá que está fora de alcance; isto está entre nós.

Maurice Blanchot 


\section{RESUMO}

Trinca, R. T. (2012). O Real nos fatos clínicos psicanalíticos: entre o esquecimento e a sua visitação. Tese de Doutorado, Instituto de Psicologia, Universidade de São Paulo, São Paulo.

Este trabalho trata da visitação do Real nos fatos clínicos psicanalíticos e dos modos de esquecimento do Real. Buscamos, neste estudo, caracterizar a visitação do Real como negativa, de modo que observamos tratar-se de uma visitação feita pelo nada, pelo desterro, pela solidão e pela orfandade. Essas formas de visitação foram descritas como acontecimentos desancoradores que ocorrem no interior do palimpsesto de pensamentos oníricos inconscientes, de um modo não programado ou esperado, e como expressões de uma radical alteridade que se impõe sobre o psiquismo. Essa imposição, ou demanda do Real, é tratada como parte do processo analítico, tal como fora designado por Bion como mudança catastrófica, uma mudança que implica o reconhecimento do esquecimento e da dissimulação do Real, e também a possibilidade de manutenção de um ponto ausente da experiência emocional como seu centro desconhecido e ainda não desenvolvido. Por fim, tratamos da diferença entre o possível e o impossível na prática clínica psicanalítica: o que não pode (ainda) se escrever e o que não cessa de não se escrever na experiência emocional, ambos aspectos da visitação do Real nas sessões em que ocorre psicanálise.

Palavras-chave: Psicanálise. Realidade. Fatos clínicos. Pensamento onírico. Clínica psicanalítica. 


\begin{abstract}
Trinca, R. T. (2012). The Real in the psychoanalytic clinical facts: between the forgetfulness and its visitation. Doctoral Thesis, Institute of Psychology, University of São Paulo.

This thesis analyzes the visitation of the Real in the psychoanalytic clinical facts and the manners of forgetfulness of the Real. We looked for, in this study, to characterize the visitation of the Real as negative, so that we observed to be a visitation done by the nothing, by the exile, by the solitude and by the orphanage. These visitation forms were described as disanchored events that happen inside the palimpsest of unconscious dreamlike thoughts, in a way no programmed or expected, and also as expressions of a radical alterity that is imposed on the psyche. This imposition, or demand of the Real, is treated as part of the analytical process, such as it had been designated by Bion as catastrophic change, a change that implicates the recognition of the forgetfulness and of the dissimulation of the Real, and also the possibility of maintenance of an absent point of the emotional experience as its unknown and still no developed center. Finally, we analyzed the difference between the possible and the impossible in psychoanalytic clinic practice: what is not (still) able to writes itself and what does not cease of not writing itself in the emotional experience, both aspects of the visitation of the Real in the sessions in that psychoanalysis happens.
\end{abstract}

Keywords: Psychoanalysis. Reality. Clinical facts. Dreamlike thought. Psychoanalytic clinic. 


\section{RÉSUMÉ}

TRINCA, R.T. (2012). Le Réel dans les faits cliniques psychanalytiques : entre l'oubli et son apparition. Thèse de doctorat, Institut de Psychologie, Université de São Paulo.

Le présent travail porte sur l'apparition du Réel dans les faits cliniques psychanalytiques et sur les modes d'oubli du Réel. L'objectif est de caractériser négativement l'apparition du Réel dans la mesure où il s'agit d'une apparition régie par le néant, le bannissement, la solitude et le délaissement. Ces types de apparition ont été décrits comme des événements déracinants qui se produisent de manière non programmée ou attendue au sein du palimpseste de pensées oniriques inconscientes, ainsi que comme expression d'une altérité radicale qui s'impose sur le psychisme. Cette imposition, ou demande du Réel, est traitée en tant que partie du processus analytique nommé changement catastrophique par W. R. Bion; un tel changement implique la reconnaissance de l'oubli et de la dissimulation du Réel, mais aussi la possibilité de maintien d'un point manquant de l'expérience émotionnelle comme son centre méconnu et pas encore développé. Enfin, le travail vise l'étude de la différence entre le possible et l'impossible dans la pratique clinique psychanalytique: ce qui ne peut (encore) s'écrire et ce qui ne cesse de ne pas s'écrire dans l'expérience émotionnelle - deux aspects de la présence du Réel dans les séances psychanalytiques.

Mots-clés : Psychanalyse. Réalité . Faits cliniques. Pensée onirique. Clinique psychanalytique. 


\section{SUMÁRIO}

INTRODUÇÃ̃ ..........................................................................................................11



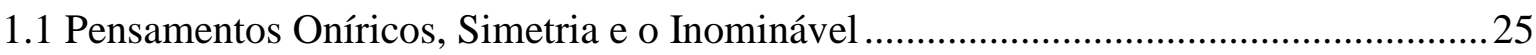



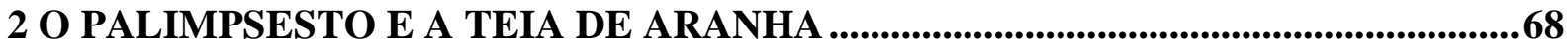

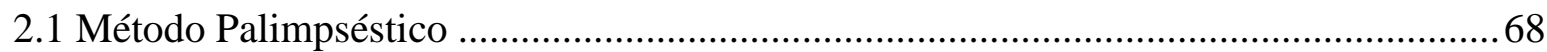



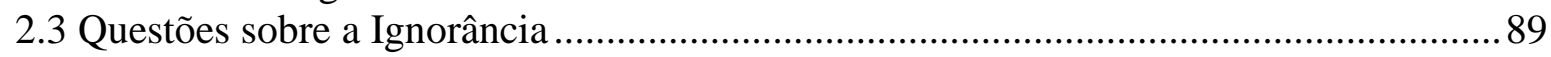



2.5 Uma Nova Questão e os Objetivos do Trabalho ....................................................... 99

3 NARRATIVAS CLÍNICAS PSICANALÍTICAS........................................................101

3.1 Rei Posto, Rei Deposto e a Cabeça Costurada: a Orfandade e o Anseio pelo Rei ....... 105

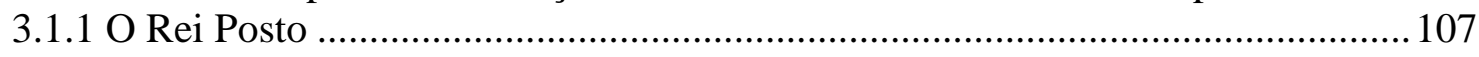

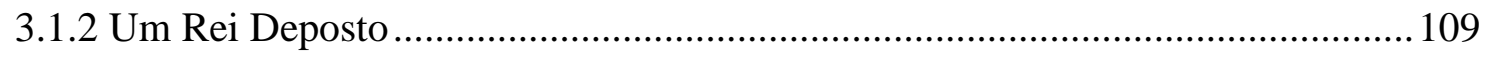



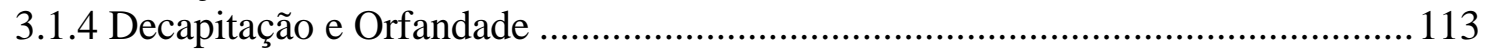

3.1.5 A Solidão e as Âncoras no Porto..................................................................... 115

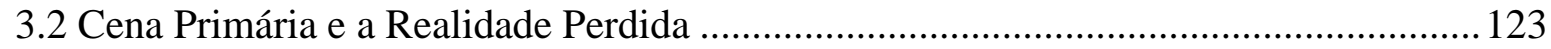

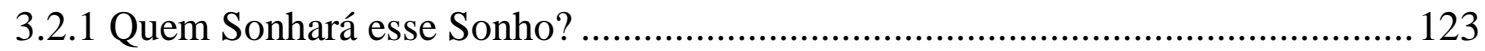

3.2.2 Entretenimento e a Realidade Perdida ............................................................... 138

3.3 Andarilho de Pés Inchados .................................................................................... 150

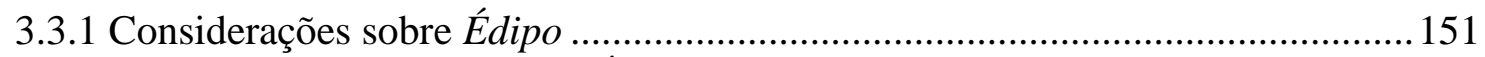

3.3.3 Dissolução do Complexo de Édipo? ............................................................... 162

4 A QUATERNIDADE NEGATIVA E O SEU ACONTECIMENTO...........................173

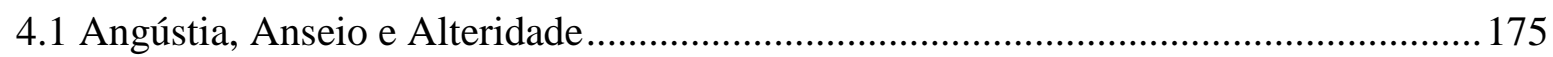

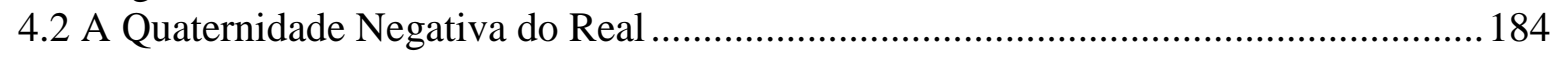

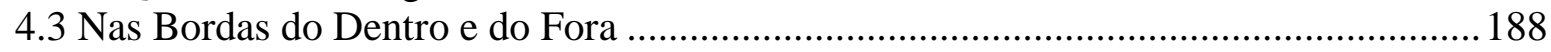

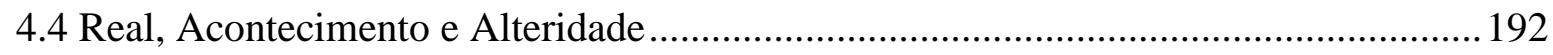

4.5 As Preconcepções e a Tolerância à Frustração............................................................ 198

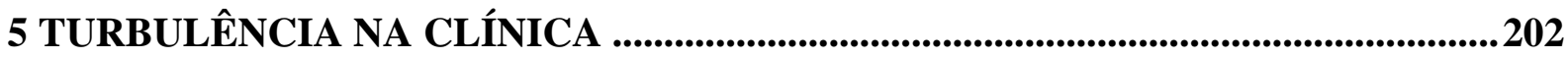

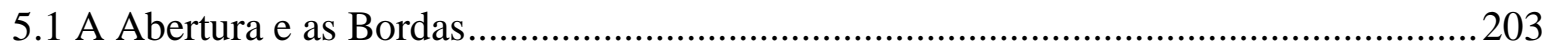

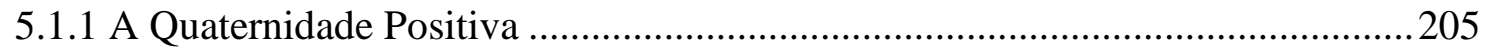

5.1.2 O Eu Mesmo como Estrutura Mítica .......................................................................2212

5.1.3 Não Mesmo, Alteridade e Trauma ……............................................................22 221

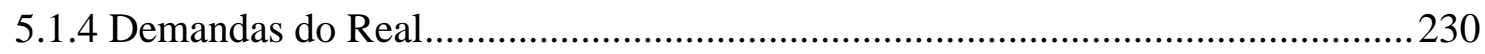

5.1.5 A Castração e o Outro Quarto .........................................................................2. 235

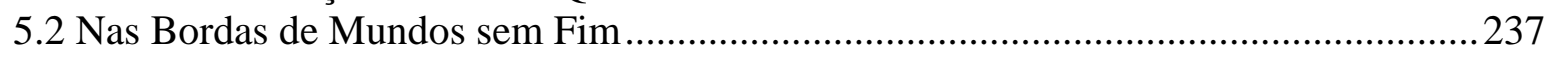

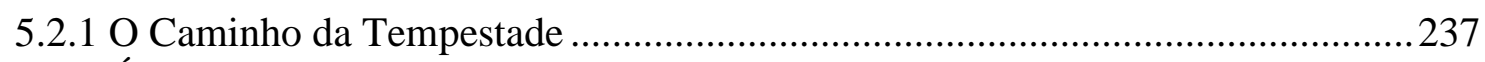

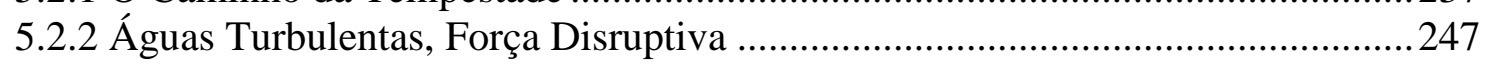

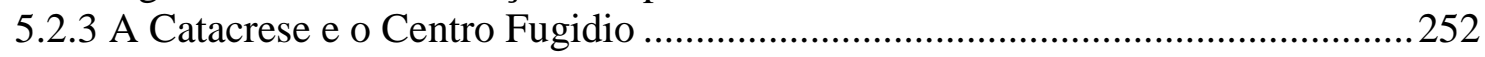


6 O REAL NOS FATOS CLÍNICOS PSICANALÍTICOS

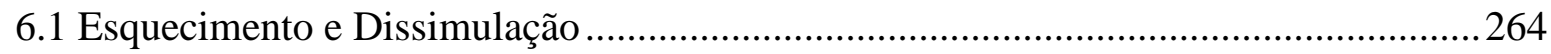

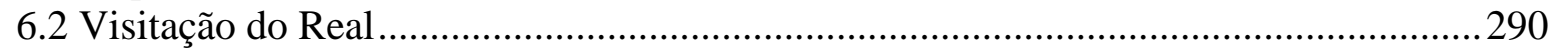

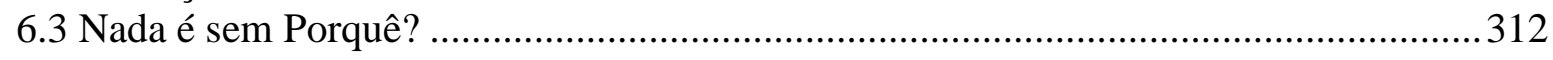

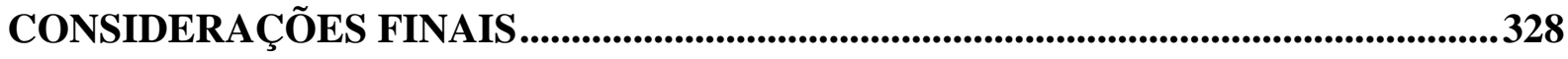

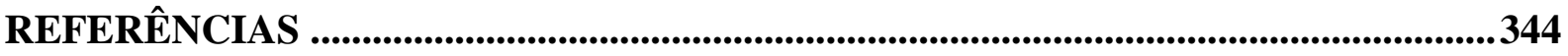




\section{INTRODUÇÃO}

Philips (1987) declarou, em uma entrevista, que era preciso lembrar que num lindo dia, atrás do radiante céu azul, escondem-se as estrelas. Essas estrelas, invisíveis para nós, estão presentes no céu, mas se encontram além da aparência sensorialmente apreendida, atrás desse véu iluminado de azul. Quando podemos olhar para elas, em uma noite sem nuvens e sem que uma luz excessiva ofusque-nos a sua apreensão, percebemos, com elas, o passado. Um passado em forma de pontos iluminados chega-nos, assinalando acontecimentos ocorridos na vastidão do infinito, e pode ser observado por nós como a presença desse passado no presente, como a presença do desconhecido; esses pontos iluminados são estranhas luzes de épocas remotas, cercadas pela escuridão da noite sem fim do infinito silencioso.

Quando olhamos para aquilo que não é visível à luz do dia, quando criamos condições para observar algo além do que nossa percepção poderia ver, observamos, em um universo de possibilidades, a luz de um passado chegar até nós e ser recontada no momento presente, como uma história atual, narrada por nós no tempo presente, mesmo sendo uma história simultaneamente antiga e incompreensível. Sabemos, como um sonhador que compreende o seu sonho (Grotstein, 2003), que ela se originou em algum lugar e por algo, mas desconhecemos quase tudo.

As luzes tornam-se histórias que narramos após observarmos com assombro e surpresa, primeiramente, esse desconhecido que a tudo rodeia. Essa história contada pelas luzes dos astros é análoga à nossa própria história e também à história de nossas origens. Sabemos que não podemos mudar o infinito ou deslocar estrelas de lugar, mas, se tolerarmos essa assombrosa realidade, quiçá ampliaremos nossa capacidade de apreender nossa incerta condição, deixando que aquilo que já somos possa eventualmente sofrer a visitação inesperada daquilo que se procura esquecer, para o qual criamos dissimulações: o Real. Perceber e, acima de tudo, 
possibilitar essa continência, transformando-a em formas possíveis de um pensar, talvez se chame psicanálise.

Mas qual a importância das estrelas distantes se não servirem para nos ressituarmos em nosso microcosmo? Para que, por meio delas, nosso pequeno universo cotidiano seja revisto e reencontrado novamente, agora marcado pela dimensão heterogênea de uma estranha estrela que brilha, marcado pela dimensão de nosso inconsciente! Uma estrela, vestígio do passado em forma de iluminação presente, apenas poderá ser relevante se for observada entre as crianças, entre o alvoroço dos pássaros, entre a contagem do dinheiro do pão e da escuta do latido insistente do cachorro. Assim, situada entre a estrela e o cotidiano não surpreendente, nossa história não poderá ser recontada de modo mais enigmático? Pois, se elas puderem, em sua inaparência cotidiana, lembrar-nos de que não só miramos para elas, mesmo sem as ver, como sua luz permanece no céu azul, que a esconde, serão, mesmo assim, relevantes para nós? Essas estrelas parecem ser um desconhecido sempre presente, vestígios enigmáticos de acontecimentos passados, que iluminam com uma luz incerta nossa inquieta imaginação; imaginação que produz as histórias de um passado, as suas incertas explicações, pois a contemplação dos astros longínquos é quase sempre complementada por nossas explicações.

Bion (1976/1985) perguntou-se se as explicações do desconhecido não seriam, por isso, do ponto de vista da psicanálise, apenas a formulação de uma vasta gama de paramnésias, criadas diante de nossa profunda ignorância. E essa pergunta não deixa de ser ecoada em nós neste momento, ecoada como um aflitivo receio de que possamos produzir apenas ilusões defensivas e dissimuladoras, mas torna-se, mesmo assim, necessário que, ao escrever, possamos ter como pano de fundo também esse receio e esse problema. Assim, perguntamo-nos: o que poderíamos apreender se, ao invés de mirarmos os astros, as luzes das estrelas, mirássemos o próprio infinito? Acaso as figurações que eventualmente surgissem não estariam envolvidas por essa escuridão resplandecente do infinito informe? 
Caso pudéssemos criar nossa própria cegueira, tal como nos indica Freud (1912/2006a), para que enxergássemos aquilo que não é apreensível apenas com os sentidos e, nessa cegueira, olhássemos para as estrelas que estão atrás do véu azul e víssemos diversos vértices (Bion, 1970/1991a), possibilidades variadas, de modo que nos mantivéssemos indecisos, inseguros e contraditórios até que, inesperadamente, um padrão emergisse, ele emergiria como um fato selecionado (Bion, 1962/1991b). Poderíamos observar que aquilo que se mostrou para nós é um acontecimento proveniente do que, até esse momento, era absolutamente desconhecido e se tornou uma transformação desse desconhecido, em uma figuração incompleta e organizada. Podemos querer desvelar o desconhecido - querer fazer com que os astros apareçam - ou estar receptivos para receber o impacto, em meio a uma massa de estímulos incoerentes entre si, de um padrão, de uma palavra, de um sentimento, de uma sensação, quando isso vier, da forma como vier, envolvidos pela incerteza que torna uma narrativa incompleta. Certamente isso implica poder aguentar serenamente, com paciência, a transgressão de um conhecimento e de uma experiência anterior, mas é bem verdade que, se fantasiamos saber sobre um paciente ou sobre nós mesmos antes de produzirmos uma sessão de psicanálise, inviabilizamos a própria psicanálise, a própria pesquisa e nosso contato transgressor com a realidade psíquica não sensorial.

Bion (1967/2000a), em seu trabalho Notas sobre memória e desejo, oferece-nos uma preciosa contribuição quando afirma que nossa atenção deveria se dirigir para o incognoscível. No entanto, nosso foco, tal como em um telescópio que mira o céu infinito, não parece simplesmente ser dirigido para o infinito. No infinito, não há foco; quando apreendemos um foco, inevitavelmente um objeto revela-se diante de nós. Assim, em psicanálise, se miramos para o infinito, deveríamos suportar a falta de foco e deixar com que o foco surja, sabendo que será a visão de uma realidade que se encontra, em seu aparecimento, envolvida pelo universo escuro e sem foco - sem formas - do próprio infinito. Um objeto do infinito poderá, assim, estar 
permeado e poroso à presença do infinito. Se o foco surgir, isso significa que, de algum modo, ocorreu aquilo que, na antiguidade medieval, era designado como sinergia, ou seja, que podemos alcançar aquilo que nos alcançou. Mas o desejo pelo foco pode nos alienar justamente daquilo para o que nossa atenção inicialmente se dirigiu: esse mais primordial desconhecimento, que ainda não se tornou estrela, palavra ou pensar.

Parecemos nos situar, na psicanálise, nas bordas de fatos clínicos envolvidos pela escuridão e ausência de formas, nas bordas de tudo aquilo que ainda não existe sob a forma de um pensar. Tão fantástico pode ser o foco e o descobrimento de algo novo, por uma mente que quer conhecer e que vai em direção aos astros distantes, que nos esquecemos daquilo que é o próprio escuro e o vazio, que a tudo circunda. Em um mundo repleto de significações, em que sofremos pelo excesso da nossa própria significação, do pensado, pela sensação de que tudo tem um sentido pretérito, presente ou futuro, é compreendido, explorado e nomeado, torna-se urgente ressituarmo-nos a partir do escuro sem formas e do vazio do infinito informe. Apenas ele poderá nos desabrigar da familiaridade mundana excessivamente saturada, para que possamos rever a face humana despossuída de memória, desejo e compreensão. Assim, talvez possamos ampliar a apreensão da nossa realidade pessoal e coletiva, pois senão, pelo foco, apenas veremos estrelas que, distantes de nós, não têm importância maior do que aquela relatada por Szymborska (2011):

\footnotetext{
A estrela é extraordinária

mas isso ainda não é razão

para não beber à saúde das nossas senhoras

incomparavelmente mais próximas. (p. 67).
}

Nossa face humana não está inevitavelmente refletida no espelho vazio e sem formas do universo escuro? Assim, qual será esse reflexo que a escuridão, tal qual espelho vazio, poderá revelar de nossa face humana? Acaso ela nada refletirá? Como soará o latido do cão, qual 
sentido terá o dinheiro do pãozinho francês ou como a brincadeira das crianças revela-se por meio desse espelho escuro? Isso precisa, no entanto, ser suportado por nós.

Pascal (citado por Bion, 1965/2004a), por exemplo, expressou: “o silêncio dos espaços infinitos me assusta [Le silence de ces espaces infines m'effraie].” (p. 184). Essa frase parece ecoar, como um grito de todos nós, até o nosso presente. Será que não se torna necessário voltarmo-nos novamente para esse antigo e ancestral medo? Como nos disse Kafka (1993), “a tarefa que nos cabe é a de realizar o negativo: o positivo já nos foi concedido.” (p. 97). Realizar o negativo não significa apenas torná-lo uma positiva claridade figurada; o negativo, para a sua realização, parece clamar também por fazer da claridade escuridão e da figuração uma teia trespassada pelo nada.

Assim, pensamos que, além do foco, além da descoberta, além da profundidade do infinito, não podemos perder de vista a dimensão do escuro da noite ou da negatividade, que não só circunda, mas penetra na positividade de nossa experiência. Isso equivale dizer que podemos estar tão enfeitiçados por nossas teorias e descobertas positivas psicanalíticas que nos tornamos subitamente alheios ao Real.

O Real, tal como procuraremos mostrar neste trabalho, é o fundamento negativo de certo movimento interno das sessões em que ocorre a psicanálise. A sua visitação ou o seu esquecimento nas sessões depende de como o par analista-analisando pode, em determinado momento, conter, além da transitória verdade que o atinge, aquilo que ainda falta se dizer, o que não cessa de não se dizer ou a destituição de cada verdade previamente formulada pela memória. Pretendemos demonstrar, por meio de narrativas clínicas psicanalíticas, que o Real parece visitar e ser esquecido, e que é também certo acontecimento dentro das sessões relacionado com a capacidade do analista e do analisando de experimentar a negatividade que está inerente, ocorrendo e fundamentando, por uma falta de fundamento, os fatos das sessões. Há, portanto, uma visitação do Real em que acontece o nada, o desterro, a orfandade e a 
solidão originária. Neste trabalho, procuramos desenvolver um pensamento que possa explicitar esse acontecimento.

Mas é importante situarmos o Real de um ponto de vista psicanalítico. No entanto, na vastidão que é hoje o movimento psicanalítico no mundo e também no Brasil, não conseguimos nos manter disponíveis para tudo aquilo que é desenvolvido. Certos cortes, limitações, desconhecimentos e escolhas tornam-se inevitáveis e a expressão mesma de um caminho.

Sabemos, por exemplo, dos profundos desenvolvimentos da noção de real no movimento psicanalítico francês, em especial por Lacan (1964/1985a, 1975/1985b). Não nos detivemos especialmente sobre essas leituras, muito embora pareça que, ao tratar de um estudo sobre o Real, seria necessário um desenvolvimento maior sobre esse autor. No entanto, nossa intenção não é explorar e apresentar um conceito, tal como foi elaborado por um psicanalista ou por uma escola; gostaríamos de usar a palavra 'Real' para poder falar - em parte - sobre aquilo que já foi falado anteriormente por outros autores, em especial por Bion (1965/2004a), com sua contribuição sobre a realidade última, e por Safra (2007), que pôde, pela primeira vez, indicar algumas figuras do Real, tal como apresentamos neste trabalho, sob a designação 'visitações'. Gostaríamos, também, que essa formulação do Real não fosse desvinculada daquilo que realmente é: um trabalho de pesquisa clínica psicanalítica.

Quando Bion (1965/2004a) formulou sua noção de realidade última, seu interesse era representá-la por uma grafia - “O” - que não significasse coisa alguma e, por esse motivo, pudesse ser completamente dessaturada, ou seja, que não estivesse repleta de significações e compreensões anteriores. Sua intenção, com isso, era mostrar a necessidade de manter o pensamento humano em atividade contínua, em um movimento para a apreensão da realidade e da verdade, que poderiam se tornar encarnadas e inacabadas mesmo no porvir.

Por isso, ao usarmos a palavra 'Real', estamos fazendo uso de uma palavra que, em certo sentido, é amplamente usada e tem os sentidos mais diversos, podendo significar, 
portanto, uma ampla gama de sentidos contraditórios entre si. Além disso, estamos nos recusando a fazer um trabalho sobre "O", que correria o risco de se tornar a repetição saturada das contribuições de Bion (1965/2004a) e dos autores que escreveram sobre esse assunto antes e depois dele. Isso, do nosso ponto de vista, seria contrário ao próprio ponto de vista bioniano, que não parece tratar esse assunto de uma perspectiva eminentemente conceitual, como uma formulação que tende a criar uma cessação do que (ainda) não pôde ser pensado. Desse modo, pensamos que, ao falarmos sobre o Real, estaremos podendo criar profundas relações com "O", sem que nos tornemos prisioneiros do seu significado positivo, um significado que, se for transformado em conceito lógico, pode justamente nos alienar de nosso propósito de pesquisa clínica, que pôde encontrar justamente neste trabalho alguma compreensão para essa temática, que é essencialmente uma temática do não saturado.

A palavra 'Real' escrita em letra maiúscula pode, ainda, ser palco de equívocos. Sua opção, em detrimento do uso do " $r$ " minúsculo, justifica-se pela tentativa de designar algo que não seja o mesmo que o real, tal como é entendido costumeiramente na linguagem cotidiana, ou seja, como fato, como aquilo que existe realmente ou como as coisas realmente são; coisas materiais, distintas de ficções (Houaiss, 2009).

O emprego da letra maiúscula pode também ser entendido equivocadamente como a expressão de uma nomeação em que "Real" torna-se uma espécie de ente supremo, de uma “superontificação". Nosso propósito, no entanto, é justamente o oposto deste. Pretendemos, com esse uso, tornar essa palavra - Real - uma distinção para o uso corrente de real e poder, com isso, elevá-la a uma posição de transcendência da palavra no seu sentido mediano. Sabemos que, para isso, seu emprego mais exato há de ser, portanto, esse: Rél. Um Real escrito e marcado com a cruz de Santo André, que assinala que a palavra precisa, para ser devidamente compreendida, estar simultaneamente sendo negada, sendo sempre riscada, revista 
constantemente em seu aspecto definitório, sempre rompida em sua forma usual, rompida por sua negação.

Neste trabalho, iremos inicialmente discutir sobre os registros de presenças sobrepostas no psiquismo, ou seja, sobre as inumeráveis camadas de pensamentos oníricos inconscientes, que foram formuladas pela primeira vez por Freud (1900/2006b), na A interpretação dos sonhos. Essa imagem representativa e fecunda do psiquismo humano levou-nos a prosseguir nessa direção e passamos a combiná-la com a noção desenvolvida por Bion (1960/1992, 1958/1994a) de palimpsesto, tal como fora descrita pelo autor em algumas passagens de seus trabalhos.

Essa combinação articulou-se, ainda, com a descrição de Safra (2007) sobre o Real, uma negatividade ontológica que atravessaria cada camada do palimpsesto, expressão de aspectos simultaneamente preconcepcionais e originários do nosso anseio por pessoas, coisas, terra e paternidade, e também origem do anseio e necessidade das escritas sobrepostas do palimpsesto. E com a intenção de situá-las de um ponto de vista psicanalítico, a partir da ideia da sobreposição dos pensamentos oníricos inconscientes, encontramos em um escritor, distante e simultaneamente tão próximo do movimento psicanalítico (Pessanha, 2000), uma imagem poética que assinala analogicamente a proximidade da biografia humana e a tessitura da teia de aranha, dependurada no escuro da noite. Podemos dizer que a estrutura geral de nosso trabalho nasceu com a formulação de uma ligação incompleta entre esses pensamentos, que parecem ser inicialmente dissociados.

A ideia da existência de camadas sobrepostas é presente tanto na psicanálise quanto na literatura. Ungaretti (1914-1919/2003), por exemplo, ao comentar sobre o título de seu livro Il porto sepolto, diz-nos:

Falavam-me [os amigos franceses da infância] de um porto submerso que devia ter precedido a época ptolomaica, provando que Alexandria já era um porto antes mesmo de Alexandre, que 
antes mesmo de Alexandre já era uma cidade. Disso nada se sabe. Aquela minha cidade se consome e se aniquila de instante a instante. $\mathrm{O}$ que podemos fazer para saber de suas origens se não persiste nem mesmo o que acaba de suceder? De nada se sabe, não persevera nenhum outro sinal além daquele porto conservado no fundo do mar, único documento transmitido de tudo o que foi Alexandria. (p. 195).

Evidências ou sinais do desconhecido são, por vezes, descritos como vestígios daquilo que pode estar profundamente recalcado. Seguindo um modelo arqueológico, Bion (1974/1975) descreve uma lenda, cujo propósito seria o de reconstruir, de um ponto de vista da tradição freudiana das construções em análise, as catástrofes ocorridas no psiquismo. Essas catástrofes, por vezes esquecidas e por vezes soterradas, fariam parte das camadas de registros desse palimpsesto, que parecem ser irrecuperáveis. Essa descrição, incluída em seu trabalho A grade (1963), foi também contada quando esteve em São Paulo, em 1973; ele denominou-a A lenda do Cemitério de Ur e contou-a assim:

Quando o rei morreu, todos os membros da corte se dirigiram para uma escavação, então denominada 'A Cova da Morte' - e aí, nos seus mais finos trajes e todas as jóias, tomaram uma droga em pequenos cálices, ulteriormente encontrados ao lado de cada corpo. Quatrocentos anos depois, sem qualquer publicidade, as tumbas foram saqueadas. Foi algo corajoso que se fez, porque o cemitério tinha sido santificado pela morte e o sepultamento da família real. Os saqueadores foram os corifeus do método científico. (Bion, 1974/1975, p. 13).

As camadas desse palimpsesto humano não são apenas camadas nítidas de escritos sobrepostas; podem ser também escritos soterrados, uns sobre os outros, e inaparentes, como estrelas num céu azul; podem ser apenas ou tão somente certa presença de uma ausência, de algo que evidencia que "há" algo lá que já não existe mais ou que nunca foi realmente escrito. Essas camadas podem estar escritas, sobrepostas, submersas, soterradas, apagadas ou simplesmente não existir ainda como narrativas ou como um pensar, mas ser, ainda assim, possibilidades, aquilo que não pode (ainda) se escrever. 
Mas um trabalho que pretende reescrever ou reconstruir desastres ocorridos com escritas soterradas, escritas que não conhecemos mais, não poderá ser análogo à entrada no Cemitério de Ur? Bion (1974/1975) descreveu o medo dessa (re)construção como o medo de uma profanação, que poderá estar mais ou menos presente como o pressentimento da iminência de uma catástrofe por parte da dupla analista-analisando, por entrar em regiões obscuras ou, até mesmo, amaldiçoadas da mente. Isso porque, nesses recônditos esquecidos, não há somente a (re)construção por meio de fragmentos dispersos e eventualmente parciais, mas o escuro ou a ausência de figuração, a presença de uma figuração impossível de se ter, e essa (re)construção seria a apreensão angustiante de uma figuração sem figura, de uma figuração negativa.

Nessa figuração sem figura, parece surgir a presença de algo que não se formaliza e que acontece em nós como a destituição de nossos sentidos familiares. Trata-se, portanto, de um ancestral medo: o medo do infinito informe, do Real. Mas, como profanadores da tumba, temos, como analistas, sempre a esperança de que reencontremos esse assombro no mistério de uma pujança inconsciente, do desconhecido que surge na alteridade e diferença de nós mesmos, que surge pelos derivados do inconsciente, por palavras e registros que, por vezes, parecem ser tão incompletos. Embora estejamos investigando uma tumba, evidências de escritos apagados, ou o brilho de estrelas de um remoto passado, um referente invisível, eles pertencem tanto a esse passado inabarcável quanto ao presente. O palimpsesto é, na verdade, o psiquismo cuja (re)construção suscita catástrofe e maldição.

Essa tumba, portanto, pode suscitar as mais variadas traduções e interpretações. Trata-se da origem pela curiosidade ou pelo desejo de conhecer, que pode tanto ser expressão arrogante e alienada do desastre (Bion, 1957/1994b) quanto de certo movimento de transformação da realidade última, com a intenção de desenvolver pesquisa e compreensão. Nesse sentido, podemos também compreender o palimpsesto como o registro outrora formulado de apreensões de nossa realidade incognoscível. 
Estaremos pressupondo, como método de trabalho, a existência analógica do Cemitério de $U r$, com a intenção de, ao entrar, poder descrever seus objetos e seu esplendor, para posteriormente tecer narrativas por meio de ficções e exames interpretativos de uma história plural e derivada de um pano de fundo de um sem número de histórias latentes (Ricoeur, 2010). Mas o nosso interesse primordial neste trabalho é o de demonstrar como podemos apreender, nesse palimpsesto, o próprio Real, ou seja, nosso propósito será o de pensar em como podemos olhar para o escuro da noite e manter o foco na vastidão infinita do espaço, antes de nos sentirmos atraídos por uma estrela que brilha, que clama por nosso olhar e por nossa atenção; e assim, após o foco surgir e com ele se formularem um objeto e uma proposição a seu respeito, como podemos manter essa nomeação aberta não somente ao (ainda) não formulado, como também ao informulável, impossível Real. Nosso método terá como finalidade justamente a possibilidade de extrair das camadas de pensamentos oníricos inconscientes o próprio Real e, assim, poder diferenciá-lo daquilo que é uma transformação para um pensar, atividade da função alfa (Bion, 1962/1991b), para a elaboração de narrativas, concepções, conceitos e sistemas dedutivos científicos, em uma progressão expansiva do próprio pensar.

Compreendemos, assim, que a imersão na personalidade humana significa a apreensão de uma realidade psíquica plural e multifacetada, que se apresenta como multiplicidade. Além de encontrarmos evidências de registros antigos, de realidades que parecem ter se perdido no tempo, de longínquas estrelas que parecem existir em um frágil e incerto brilho repentino, há também uma atividade humana de procurar registrar, por meio de aparentes lembranças, aquilo que não aconteceu; de criar, no vácuo de nossa ignorância, narrativas que se confundem com a história de uma biografia. Podemos criar, nesse vácuo de nossa ignorância, uma lembrança alienada e mentirosa que nos aliena do vácuo aterrorizante do desconhecido, seja ele de um registro esquecido, seja ele de uma abertura ao inominável. 
Além dos registros, além das evidências de desastres ou de "covas da morte", há - além das camadas e permeando-as - o motivo de nossa pesquisa atual. Iremos, neste trabalho, pensar o Real também do ponto de vista de seu esquecimento, ou seja, de como podemos permanecer alienados de sua experiência pela imersão na vida indisponível, tamponada e mediana do sentido repetitivo do cotidiano, nos registros da narrativa que não cessou de se escrever, em que não suportamos a instabilidade de qualquer negatividade ou o inevitável inacabamento do pensar, o seu ponto ausente, Real.

O primeiro capítulo trata do impacto frente à apreensão e ao limite do dizer, tanto da realidade psíquica palimpséstica, nomeada inicialmente como o conjunto de pensamentos oníricos inconscientes, quanto do inominável Real. Tratamos, nesse primeiro capítulo, sobre a possibilidade da interpretação da realidade desconhecida e pensamos, como Freud (1900/2006b), na A interpretação dos sonhos, que a interpretação deve, de modo geral, ser dirigida a apenas determinado pensamento onírico ou sentido inconsciente e que os pensamentos oníricos inconscientes são extremamente vastos, conglomerados reunidos de modo contraditório; trabalhamos esse assunto procurando compreender o sentido da simetria dos processos inconscientes, com especial ajuda que faz Matte-Blanco (1975/1998) sobre esse assunto. Há uma alteridade que atravessa nosso psiquismo na forma de uma visitação, uma passagem da heterogeneidade. Nesse primeiro capítulo, discutimos esse problema.

O segundo capítulo trata do método usado neste trabalho. Descrevemos esse método, inicialmente, por meio de uma história, cujo propósito é tornar claro o emprego que faremos da noção de palimpsesto e de como o Real pode ser pensado por meio de uma posição geométrica em relação ao palimpsesto. Além disso, esse capítulo procura mostrar que o método usado neste trabalho não se difere de outros métodos psicanalíticos, ou seja, observa a importância da manutenção de uma situação de isolamento dentro de uma situação de intimidade e do foco pela apreensão da realidade psíquica desconhecida. Nesse capítulo, procuramos, além de 
contextualizar esses termos, realizar uma aproximação inicial da ideia de fato clínico psicanalítico.

No capítulo seguinte, descrevemos três narrativas clínicas, com o propósito de contá-las com uma perspectiva em que a temática do Real parece surgir como aquilo que está inerente às sessões e que não pode ser pensado pela dupla satisfatoriamente; como um esquecimento de uma visitação. Nas três histórias clínicas descritas, que são histórias clínicas mescladas com descrições literárias, extraímos os temas que serão desenvolvidos no capítulo posterior, em especial, as descrições da visitação do Real, que são as expressões da orfandade, do desterro, da solidão originária e do nada.

No capítulo quatro, procuramos sistematizar e sintetizar aqueles "achados" presentes nos casos clínicos. As quatro visitações do Real têm, então, uma elaboração inicial e são compreendidas como uma quaternidade negativa do Real. Tratamos também do problema da alteridade, do ponto de vista do acontecimento do Real nas sessões de psicanálise, tal como nos mostra Figueiredo (1994), e articulamos com a noção de visitação.

O capítulo seguinte é composto de duas partes. A primeira é sobre A abertura e as bordas, que procura descrever a condição positiva do palimpsesto, ou a quaternidade positiva, e a sua relação com o eu mesmo, a alteridade e o Real, revelando essa quaternidade positiva como uma figura icônica, uma clareira aberta para a visitação do Real, com suas bordas e linhas demarcadas pelos mundos impossíveis. A segunda parte desse capítulo trata do Caminho da tempestade, que mais detidamente fala sobre o problema da mudança catastrófica como parte fundamental do desenvolvimento da apreensão do Real na clínica psicanalítica, como sinal de expansão e ruptura.

Nosso último capítulo versa sobre o problema da visitação e do esquecimento do Real e sobre o problema de sua fundamentação em relação ao determinismo psíquico e à associação livre, articulando essa polaridade visitação/esquecimento, com o problema do lugar situado 
"entre" territórios inabitáveis, como o lugar da alteridade/diferença, da criatividade e da multiplicidade.

As considerações finais procuram compreender o percurso deste trabalho, por meio da interpretação das suas linhas centrais, como aquilo que não cessa de se escrever, como aquilo que não cessa de não se escrever, como aquilo que cessa o não se escrever, como aquilo que não pode (ainda) se escrever e, finalmente, como aquilo que se escreve, um pouco mais. Essas cinco formulações procuram interpretar nosso modo de escrita e, ao mesmo tempo, oferecer um resumo dos passos seguidos até o final do trabalho.

Os capítulos foram, inicialmente, elaborados a partir de uma estrutura de pesquisa em que introdução, metodologia, desenvolvimento, resultados, discussão e conclusão organizaram a ordem inicial da sequência e do desenvolvimento dos capítulos, servindo como preconcepções cujo propósito era abrigar o acontecimento de um pensamento que ainda não havia sido desenvolvido. No entanto, tal como andaimes ou escoras de uma obra, foram retirados a seu tempo, visando a dar visibilidade para o método que estava sendo desenvolvido e empregado nesta pesquisa: o método psicanalítico palimpséstico. Mas o leitor poderá, ainda, encontrar em sua leitura tais registros, tais vestígios, mesmo que sobrepostos, submersos, soterrados ou apagados. 


\section{A PASSAGEM DO OUTRO EM SUA ALTERIDADE}

\subsection{Pensamentos Oníricos, Simetria e o Inominável}

Levinas (1997), em uma entrevista concedida a Philippe Nemo e François Poirié, realizada cerca de quinze anos antes de seu falecimento, fez um breve comentário sobre seu livro Da existência ao existente, que possivelmente foi escrito na obscuridade de um cárcere nazista, quando - refém de um futuro incerto, na solidão do interior de uma floresta em que as notícias da guerra e dos outros nunca chegavam - pôde testemunhar a presença impessoal daquilo que denominou "terceiro excluído". Gostaríamos de citar esse trecho da entrevista:

Para mim ['há'] é o fenômeno do ser impessoal: 'ele'. Minha reflexão sobre o tema parte de lembranças de infância. Vamos dormir sozinhos, os adultos continuam sua vida; a criança sente o silêncio do seu quarto como ruidoso. Algo semelhante ao que acontece quando colocamos uma concha vazia no ouvido, como se o vazio estivesse cheio, como se o silêncio fosse um ruído. Alguma coisa que podemos sentir também quando pensamos que mesmo se não houvesse nada, o fato de que 'há' não pode ser negado. Não que exista isto ou aquilo; mas o próprio palco do ser é aberto: há. [...] De fato insisto na impessoalidade do 'há', como em 'chove' ou 'é noite'. E não há aí nem alegria nem abundância: é um ruído que retorna após toda negação desse ruído. Nem nada, nem ser. Emprego às vezes a expressão: o terceiro excluído. Não se pode dizer, desse 'há', que ele persiste, que seja um acontecimento do ser. Tampouco se pode dizer que seja o nada, ainda que não seja nada. (p. 22).

Nessa profunda passagem, que nos convida ao mergulho de uma leitura atenta, parece que somos levados a pensar imaginariamente nessa criança que permanece insone - também um terceiro excluído -, enquanto testemunha, no silêncio ruidoso de seu quarto escuro e adormecido, a marcante presença de algo que há, que não se evade e também não se revela. Algo horrível! - dir-nos-ia Levinas (1997) -, que nesse horror derrama sua sombra impessoal sobre o existente, sobre a criança insone e sobre o escuro de seu quarto, além de manter aquilo 
que seria o silêncio, o vazio ou o nada como negatividade preenchida por seu ruído, pelo ruído do ausente; de um ausente que, ainda assim, "há".

Pensar na solidão, na solidão de uma criança em seu quarto, parece ser agora, por meio dessa descrição, uma tarefa em que a solidão - e a ausência nessa solidão - parece se situar como experiência de testemunho do próprio inominável. O ruído do silêncio parece ser uma apreensão daquela presença que ainda não se transformou em imaginação, em palavra, que ainda não se transformou em rosto, em familiaridade ou sonho. Trata-se da permanência de uma impessoalidade, que permanece mesmo após toda a negação do ente. Tudo aquilo que é, todo o ente, parece assim ser uma clareira de lucidez e de aparecimento que dissipa momentaneamente essa estranha e horrível presença do inominável, que é, ainda assim, a presença daquilo que "há": a própria abertura do ser, o palco iluminado em que não se encontram atores, apenas a presença do desconhecido, como Godot. ${ }^{1}$

Temos ainda, nessa descrição de Levinas (1997), o prenúncio de um pensar que parece situar aquele testemunho da criança insone nas bordas da existência ou na tênue linha que parece demarcar um território fronteiriço familiar de outro estrangeiro, ou do próprio ser, pela escuta da abertura dessa fronteira, que não é jamais a escuta de um som qualquer. Como nos diz Assoum (1997, p. 34), nesse "afogar do eu no rumor do ser parece não mais se encontrar as referências distintas do 'dentro' e do 'fora'”, parece apenas haver o testemunho da superação dessa demarcação. Assim, essas categorias parecem ser inadequadas para descrever aquilo que Levinas (1997) descreve-nos, mas talvez seja importante que nos impliquemos um pouco mais sobre essa questão. Podemos, então, lembrar-nos de um comentário sobre o "dentro" interior e o "fora" exterior, feito por Jean Hyppolite com o intuito, parece-nos, de discutir sobre o problema de como podemos criar mitos para o funcionamento do nosso pensar. Esse comentário foi extraído de uma conferência sobre a denegação, tendo sido citado por Bachelard (1957/1989):

\footnotetext{
${ }^{1}$ Godot é o nome dado por Beckett (1976) ao personagem ausente de sua história Esperando Godot. Nessa estranha história, dois personagens esperam em vão a chegada do Sr. Godot. Iremos, no capítulo três, desenvolver e expandir essa temática.
} 
“Os senhores sentem qual é o alcance desse mito da formação do exterior e do interior: é o da alienação que se baseia nesses dois termos. O que se traduz em sua oposição formal se torna mais adiante alienação e hostilidade entre ambos.” (p. 216).

Nessa interessante passagem, o autor diz-nos que a oposição existente entre o interior e o exterior seria resultado de um processo de alienação, cujo propósito parece estar ligado com o emprego de um modo de organização da realidade. "Dentro" e "fora" são metáforas espaciais, que parecem produzir em nós certa familiaridade, uma representação que inevitavelmente nos parece soar conhecida e, assim, organizar-nos sobre aquilo que, de fato, desconhecemos. Poderíamos nos lembrar daquilo que disse Bion (1975/1989), em Uma memória do futuro: "podemos supor que a realidade seja um caos desprovido de significado" (p. 95) e, por isso, o mito - ou esse modo de uso de metáforas espaciais - pode ter um caráter organizador do pensamento.

Hyppolite (citado por Bachelard, 1957/1989) parece iniciar, assim, aquilo que será posteriormente ampliado por Bion (1975/1989), ou seja, a ideia de que os mitos são preconcepções e formas organizadoras do pensar. Nesse caso, um mito que se relaciona com a hostilidade, pelo fato de que a sua oposição haveria de resguardar os aspectos cindidos de sua contraparte. Para Hyppolite (citado por Bachelard, 1957/1989), o resultado dessa oposição, desse mito que atribui significado, criaria uma ilusão de uma realidade que permaneceria dividida em duas partes, sendo que uma delas, separada da outra, haveria de ajudar na localização, pelo eu, de fontes de angústia e de desamparo, por meio de uma geografia definida, na oposição do "dentro" interno.

Assim, a alienação criada entre o "interno" e o "externo" parece ter suas razões: identificar no "fora" exterior, por exemplo, certas fontes de desamparo ou de angústia, localizálas para poder, com isso, proteger-se (Freud, 1930/2006c). Aquilo que seria mau, estranho ao eu e aquilo que é exterior poderiam ser tratados como idênticos, de modo que o "dentro" interno 
poderia ter uma característica opositiva, que levaria a pensarmos na própria constituição do eu mesmo como fundamentada na ilusão da manutenção de um aspecto benigno interno, que não sucumbiria às ameaças de destruição, tal como nos descreve Klein (1946/2006), em suas Notas sobre alguns mecanismos esquizóides.

"Dentro" e "fora", assim como "ser" e "ente", parecem designar posições antagônicas, em que se torna difícil encontrar expressão pelo pensar daquela posição que haveremos de situar como pertencente às bordas do antagonismo ou, ainda, que revele como a própria diferença entre os antagonismos parece ser o lugar em que podemos refletir um pensar da diferença, ou melhor, da escuta e apreensão da alteridade/diferença, tão fundamental na clínica psicanalítica quanto é fundamental a manutenção do ruidoso silêncio do inominável desconhecido.

No pensamento psicanalítico, sabemos que, desde seu início, esse desconhecido foi aquela mola propulsora que elevou o pensar para a apreensão da multiplicidade daquilo que poderia ser considerado unitário, o eu mesmo, a sua identidade. Pela escuta analítica, escuta de um dizer que não cessa de não ser dito - tal como veremos posteriormente -, cujo sentido caminha inevitavelmente nesse território que não é território, mas uma borda em que há impossibilidade de se ser inteiramente e de mergulhar na coisificação do ente também inteiramente, caminhamos avistando territórios estrangeiros. Freud (1933/2006d) havia se referido a eles em relação ao reprimido e à realidade exterior, e podemos relembrá-los agora para falar também desses lugares estrangeiros, desses inabitáveis, que, embora pareçam ser também territórios demarcados, são, na verdade, registros do impossível.

Aquilo que parece estar prefigurado, na tentativa de apresentação do inominável desconhecido, é justamente um ponto ausente, que se revela como certo ponto de fuga para o qual a nossa atenção parece, de algum modo, deslocar-se e ser absorvida, principalmente quando, nessa absorção, parece não se desenvolver nenhum objeto em particular. Na 
interpretação, há justamente a permanência desse ponto fugidio ausente, que, por escapar às traduções interpretativas que são feitas, é a origem da possibilidade de uma conversa que jamais se esgota e que sempre parece ter algo mais para dizer. No entanto, a conversa infinita, a conversa que não acaba, é aquela interlocução - mesmo solitária - em que se apreende a presença contínua de que "há" um terceiro excluído, um ruído no silêncio, um Godot inevitavelmente inominável e desconhecido e que não se torna saturado por um sentido que o dissimule ou que o torne, pela saturação, um ponto inexistente. Esse desconhecido é aquilo que orienta a própria atividade analítica.

Podemos nos lembrar de que, sobre o desconhecido, disse-nos Freud (1900/2006b):

O inconsciente é a verdadeira realidade psíquica: em sua natureza mais íntima ele nos é tão desconhecido quanto à realidade do mundo exterior, e é apresentado pelos dados da consciência de modo tão incompleto quanto o é o mundo externo pelas comunicações dos nossos órgãos dos sentidos. (p. 637).

O inconsciente, como território estrangeiro, é a nomeação desse lugar inabitável; Freud (1900/2006b), com essa visão, legou-nos o testemunho de nossa condição de sermos espectadores diante da fronteira de um desconhecido. Desde $A$ interpretação dos sonhos, Freud (1900/2006b) oferece-nos inúmeras descrições sobre essa concepção do inconsciente. Suas descrições, no entanto, talvez nunca tenham obtido força mais significativa do que a sua descrição do "umbigo do sonho", aquele ponto em que o sonho mergulha no próprio desconhecido e que, muito provavelmente, não será um ponto capaz de ser transformado para um sentido com significação consciente. Em uma nota de rodapé da análise de seu sonho da Injeção de Irma, ele nos diz:

Tive a impressão de que a interpretação dessa parte do sonho não foi suficientemente desenvolvida para possibilitar o entendimento de todo o seu sentido oculto. Se tivesse 
prosseguido em minha comparação entre as três mulheres, ela me teria levado muito longe. Existe pelo menos um ponto em todo sonho ao qual ele é insondável - um umbigo, por assim dizer, que é seu ponto de contato com o desconhecido. (Freud, 1900/2006b, p. 145, nota 2).

Assim, o sentido oculto de uma parte do sonho pode ser insondável. Há uma presença, mas ela é um silêncio ruidoso, é um emaranhado de pensamentos oníricos que não se deixa desenredar, um emaranhado de pensamentos que mergulha no desconhecido inconsciente (Freud, 1990/2006b). As interpretações que traduzem esse inconsciente, nesse sentido, encontram enorme dificuldade em desenrolar esse emaranhado de pensamentos oníricos, pois, enquanto nos pensamentos oníricos todos podem estar juntos, contraditórios, nossa atitude interpretativa procura traduzir cada um desses pensamentos emaranhados separadamente, diferenciando um do outro, de modo que nossa linguagem torna-se incapaz de dizer aquilo que poderia ser essa realidade emaranhada e que, somente com uma ruptura com o modo de pensar próprio do processo secundário, racional ou assimétrico, poderia ser possível. No entanto, é esse o modo como pensamos, como escrevemos, como dizemos em nossa linguagem mediana, própria do cotidiano. Podemos observar que estamos, até esse momento, tratando esse desconhecido por vezes como um território, por vezes como um conteúdo ou pensamento onírico e por vezes como uma ausência de significação. Essas formas distintas de tratamento serão, aos poucos, diferenciadas.

Sabemos que o propósito psicanalítico de investigação desse desconhecido, marcado pela simetria como expressão de sua forma lógica, ou seja, de uma estrutura de organização de nosso pensar em que conjuntos de pensamentos oníricos antinômicos, contraditórios, conviveriam simultaneamente uns com os outros, sobrepostos, é possível pela compreensão da existência desses pensamentos ou conteúdos desconhecidos e pela manutenção da apreensão desse ponto de fuga. Entretanto, a descoberta, iluminação de determinado pensamento outrora inconsciente, não finaliza a tarefa, que é incrivelmente vasta. 
Matte-Blanco (1975/1998), em seus estudos sobre o modo simétrico de operar do inconsciente, descreveu-nos justamente essa assimetria, dizendo-nos que o pensamento lógico comum, de uma lógica argumentativa, toma em consideração proposições a respeito de relações assimétricas. Nesse sentido, trata-se de relações cujo reverso não é idêntico a elas (como, por exemplo: A está atrás de B; como reverso, B está na frente de A). Em termos freudianos, poderíamos dizer que essa lógica é própria do funcionamento do processo secundário e o inconsciente, por sua vez, trata as relações assimétricas como simétricas, ou seja, trata o reverso de qualquer relação como idêntico a ela (como, por exemplo: A está atrás de B; como reverso, B está atrás de A; ou em termos mais psicanalíticos: A está alimentando B e B está alimentando A $)^{2}$. Matte-Blanco (1975/1998) estaria, desse modo, criando condições para que pudéssemos apreender essa lógica do inconsciente, principalmente para o analista praticante, que, após as contribuições de Bion (1965/2004a) sobre a função da interpretação, ${ }^{3}$ tem recolocado o problema dos modos de acesso do analista e do paciente a esse desconhecido.

Tratando-se de uma lógica simétrica, caso a contradição não possa ser pensada dentro de uma lógica argumentativa, poderíamos simplesmente afirmar que o inconsciente é tudo aquilo que é impensável e contraditório, mas certamente essa concepção, que mais se parece com uma resposta, seria um impedimento à possibilidade do desenvolvimento do próprio pensar. Parece que o pensar pode compreender essa lógica simétrica como estando presente nas camadas de pensamentos oníricos inconscientes, sabendo que a atitude interpretativa parece repousar sobre esse problema, sobre como formular essa lógica e como atingi-la.

\footnotetext{
${ }^{2}$ Rayner (1990) discute pormenorizadamente a relação existente entre os pressupostos de Matte-Blanco e a teoria freudiana, em especial, da articulação das características do inconsciente freudiano com a noção de simetria proposta por Matte-Blanco.

${ }^{3}$ Tal como veremos a seguir, a ação de uma interpretação deve gerar, mais do que "aumentar", conhecimento. Ela deve propiciar uma experiência do paciente consigo mesmo; e uma experiência emocional que gere crescimento não pode ser obtida por um conhecimento sobre um conteúdo do paciente. Uma interpretação é outra coisa que não apenas aumentar conhecimento: é proporcionar uma apreensão de uma realidade que é, por si mesma, sem representação e sem conhecimento. Assim, a interpretação pode ser tal que favoreça a transição de conhecer sobre a realidade para tornar-se real, como experiência apreensível e não como um vínculo que denotaria uma relação de objeto, do tipo X k Y (X conhece Y). "A interpretação poderá ser tal que favorece a transição de conhecer sobre a realidade para tornar-se real.” (Bion, 1965/2004a, p. 166).
} 
No entanto, parece ser importante acrescentarmos outro ponto a essa questão. MatteBlanco (1975/1998) introduziu, em seu trabalho $O$ inconsciente como conjuntos infinitos, a ideia inovadora de que algumas experiências que os pacientes trazem na análise poderiam ser reconhecidas como possuidoras de características da infinitude. Entre elas, o autor considera que alguns sentimentos, tais como: a onisciência, a onipotência, a impotência e a idealização, seriam característicos do reinado da simetria e do infinito. Para ele, esses sentimentos expressariam, assim como nos sonhos ou no pensar esquizofrênico, que um aspecto da mente um sentimento - seria idêntico ao todo e que o tempo e o espaço tenderiam a desaparecer. Todavia - e aqui está a sua importante contribuição -, ele nos diz que as partes apenas seriam idênticas ao todo se o todo fosse infinito, ou seja, Matte-Blanco (1975/1998) vale-se de um conceito presente na matemática, que diz que um subconjunto é igual ao conjunto todo quando o conjunto é infinito. Podemos dizer, por exemplo, que o conjunto dos números naturais $(1,2$, 3, 4 etc.) é um conjunto infinito. Caso retiremos desse conjunto um subconjunto, como, por exemplo, o subconjunto dos números pares, esse subconjunto também será infinito. Assim, quando temos um conjunto infinito, as suas partes tornar-se-iam idênticas ao todo, o que equivale dizer que, se A é parte de B, então A é igual a B.

Essa é também a expressão da lógica simétrica do inconsciente, uma lógica de homogeneização (Matte-Blanco, 1975/1998). Os subconjuntos são idênticos ao conjunto todo, quando o conjunto é infinito. Em psicanálise, podemos encontrar essa atividade simétrica em relatos de pacientes que descrevem estados emocionais nos quais os processos inconscientes simétricos sobrepujam-se à atividade da consciência, revelando certa verdade antinômica do inconsciente, que parece possuir essa característica de ser, portanto, infinito. Ou seja, por inconsciente podemos designar tanto o conjunto simultâneo de pensamentos oníricos inconscientes e sua presença homogênea no psiquismo quanto a infinitude e sua ausência de formalização. 
Pensar sobre a interpretação, desse modo, leva-nos a considerar um problema próprio da lógica: como interpretar quando aquilo que deve ser interpretado não é justamente um conglomerado de formulações psíquicas inconscientes que nos faz mergulhar no insondável desconhecido de uma lógica simétrica? As traduções interpretativas parecem, nesse caso, ser formas de transformação de elementos complexos simétricos em elementos simples assimétricos ou de uma homogeneidade em uma heterogeneidade, diferença. Freud (1900/2006b), ainda em A interpretação dos sonhos, havia notado isso e resolvido esse problema na forma daquilo que denominou interpretação fracionada de um sonho. Para ele, não era raro a impossibilidade de ser consumada a interpretação de um sonho de uma única vez. Ele indicava a necessidade, portanto, de que o analista continuasse essa interpretação na sessão seguinte, de modo que pudesse, assim, interpretar outra parte do conteúdo do sonho. "Outra parte do conteúdo do sonho poderá então atrair nossa atenção e dar-nos acesso a outra camada dos pensamento oníricos.” (p. 554). É claro que aquilo que ocorre associativamente pelo paciente em uma sessão parece que deve ser respeitado, o que nos coloca dúvidas sobre continuar a interpretar um mesmo sonho em uma sessão posterior como decisão do analista, mas Freud (1900/2006b) chama-nos a atenção para observarmos o caráter complexo dos sonhos e como eles podem intrigar e manter sobre eles a nossa atenção por dias seguidos.

Nesse mesmo trabalho, logo em seguida, Freud (1900/2006b) diz-nos:

Só com extrema dificuldade é que o principiante na tarefa de interpretar sonhos se deixa persuadir de que sua tarefa não chega ao fim quando ele tem nas mãos uma interpretação completa - uma interpretação que faz sentido, é coerente e esclarece todos os elementos do conteúdo do sonho. É que um mesmo sonho pode ter também outra interpretação, uma 'superinterpretação' que lhe escapou. De fato, não é fácil ter uma concepção da abundância das cadeias inconscientes de pensamento ativas em nosso psiquismo, todas lutando para encontrar expressão. Tampouco é fácil dar crédito à perícia exibida pelo trabalho do sonho na descoberta permanente de formas de expressão capazes de abrigar diversos sentidos. (p. 555). 
Com essa descrição da atividade analítica, Freud (1900/2006b) tinha em vista a possibilidade de que o psiquismo fosse formado por uma sucessão de camadas inconscientes de pensamentos oníricos, as quais permaneceriam ativas. Essas camadas sucessivas fariam com que uma forma de representação onírica pudesse ser a representação condensada de inúmeras dessas camadas e, por isso, pudesse conter diversas possibilidades de sentido. Essa rica concepção de realidade psíquica inconsciente fornece-nos, ainda hoje, a possibilidade de pensar que a lógica simétrica do inconsciente pode ser uma lógica que abrigue justamente inúmeras camadas de pensamentos oníricos inconscientes, que podem se condensar na representação de uma imagem de um sonho.

A interpretação fracionada de Freud (1900/2006b) é uma tentativa de "dar conta" dessa inumerável possibilidade de sentido de um sonho e se baseia no pressuposto de que um sonho tem mais que um sentido e que poderemos, assim, interpretá-lo, ou seja, transformá-lo em algo que faça sentido, reconstruindo essa parte do sonho em uma linguagem assimétrica. Haveria, nessa forma de interpretação, uma necessária redução do material de um sonho, mas é justamente por essa redução, por esse vértice, que é possível interpretar e traduzir. Um vértice seria a perspectiva segundo a qual podemos observar um determinado sentido inconsciente, que pode ser compreendido e posteriormente esclarecido e comunicado. $\mathrm{O}$ sentido inconsciente presente em um sonho é um esclarecimento que pressupõe uma redução, uma tradução que se torna impossibilitada de pronunciar a riqueza exuberante de sua fonte, sendo sempre pensado por meio de um vértice, de uma perspectiva. Nesse sentido, não se torna estranho para nós que Bion (1970/1991a) tenha defendido a ideia de que o pensar, sua formulação consciente, é necessariamente falso se comparado com a verdade do fato que ele formula (Grimberg, Sor, \& Bianchedi, 1973). As interpretações psicanalíticas parecem, desse modo, pronunciar verdades sempre parciais, verdades que têm determinado vértice. 
Em seu artigo Sobre alucinação, Bion (1958/1994a) descreve uma experiência com um paciente em que determinada interpretação havia apenas fornecido um aspecto entre os demais que estariam presentes na sessão. Diz assim que: "minha tarefa era pesar bem todos os fatos ocorridos na sessão até o momento, como se esta fosse um palimpsesto onde eu deveria detectar outra configuração adicional.” (p. 86). Um palimpsesto ou uma sobreposição de camadas de pensamentos oníricos inconscientes parece ser um modo de representação figurativa dessa realidade plural, simétrica e incognoscível da mente, de uma realidade que seria a combinação de diversas possibilidades de sentidos contraditórios e da sua infinitude. Isso porque um palimpsesto, ou o "conjunto" de camadas de pensamentos oníricos inconscientes, parece resguardar, além de seus meandros, além de seus próprios conteúdos simétricos, inconscientes, antinômicos, essa pura abertura que é, fundamentalmente, a de um fundamento sem fundamento, de uma origem, cuja presença manifesta-se no trabalho clínico como aquilo que "há".

No divã "há", como no quarto da criança, o rosto do outro que não se apresenta é um rosto ausente. $\mathrm{O}$ palco analítico é o palco que quer manter a face humana ainda para ser descoberta, não apenas na familiaridade cotidiana, tampouco como pura carne, aquela face bruta do esquecimento do Real, expressão do ente em sua totalidade, cru e alienado em seu sentido. Destituir a face de seu aspecto imaginário não nos parece ser o desmonte de sentidos cujo resultado seja a face bruta, não erotizada da carne pura, mas aquela visão inominável do território estrangeiro, que apenas poderá ser vislumbrada para que, por meio dela, possamos trazer - como visitantes desse país do outro ${ }^{4}$ - os tesouros, que são janelas para a visão alargada e insaturada de nosso universo de sentido e de imaginação. O rosto do analista, esse território estrangeiro, é a face humana que se mantém como aquela alteridade que ainda não pôde ser descoberta como exuberância e desatino; ele se anuncia como aquele momento primevo do

\footnotetext{
${ }^{4}$ Tomo por empréstimo a expressão utilizada por Leclaire (1992).
} 
surgimento da multiplicidade existente, expressa em uma prefiguração que resguarda a "audição" da abertura do ser, a qual parece anunciar aquilo que é também próprio da simetria e do infinito. A face do analista-outro parece anunciar, como ícone, aqueles versos de Blake (1984):

Num grão de areia ver um mundo
Na flor silvestre a celeste amplidão
Segura o infinito em sua mão
E a eternidade num segundo. (p. 78$){ }^{5}$

Se a análise resguarda essa face ausente, o rosto do outro que não se apresenta, não é porque ela quer somente visualizar aquela ordem não sensorial da experiência, mas porque pretende refundar o próprio mundo, pela abertura do ente, do sentido, por meio do ponto ausente; refundar, portanto, parece ser poder vislumbrar, no próprio mundo de sentido, o território da face nua do inominável. No entanto, o rosto do analista é esse latente que parece ser sempre procurado e nunca encontrado, mas que, por meio dele, avista-se a beleza de um rosto que não apenas é o reflexo de nossa própria multiplicidade, mas uma abertura e presença daquilo que "há" (Levinas, 1997) e que nos acompanha como aquela presença que não nos deixa jamais inteiramente sós e que, por meio dela, também podemos permanecer sozinhos (Winnicott, 1958/1982a).

Esse impessoal, essa terrível abertura, é também o reconhecimento de que tudo pode encher-se de volume e encarnar-se voluptuosamente de exuberância na criação daquilo que poderia ser sonhado, criado e tornado existente por nossas palavras, quando procuram dizê-lo. O reconhecimento desse impessoal, que parece apresentar-se na face ausente do analista, é também a confiança na possibilidade de que se sustente o silêncio ruidoso não invadido pela

\footnotetext{
${ }^{5} \mathrm{O}$ poema original, do livro The pickering manuscript, traduzido para o português por Alberto Massicano, é: "To see a world in a grain of sand/ And a heaven in a wild flower/ Hold infinity in the palm of your hand/ And eternity in a hour."
} 
posse soberana de um sentido alienante, defensivo e ocultador, que pode surgir como expressão da defesa, pelo par analista-analisando, na situação clínica.

O impessoal também resguarda aquela terrível dignidade que não poderá ser inteiramente encarnada, que face alguma se torna, a não ser que resguarde, por sua vez, seu caráter icônico, que é de abertura e remissão para o além do ente. A face ausente do analista não é apenas um rosto ausente de sentido pretérito, presente ou futuro; é um rosto que nos envolve com o movimento infinito de superação de cada finitude criada por nós. Ela cria o movimento da análise não porque é um agente externo, que, sendo exterior, elicie-nos, catalise ou produza a experiência analítica, mas porque parece fazer surgir somente a possibilidade desse reconhecimento.

A impessoalidade desse ponto de fuga é também aquilo a que a análise visa: nessa deposição do eu mesmo para a posição transcendente da alteridade. O movimento possível da análise parece ser oriundo dessa falta de sentido originário, que vai se finitizando e encontrando - na sua necessária negação - a alteridade de um sem número de sentidos e existências possíveis. Mas a alteridade parece ser encontrada quando, na presença do silêncio ruidoso, do ponto ausente, acontece a negação do ente e a permanência dessa negação, mesmo com a impossibilidade de permanecer com isso que parece ser tão somente uma visitação, sendo que por visitação empregamos, agora, o mesmo sentido de Levinas (1993): passagem do outro em sua alteridade.

Diante da inospitalidade desse lugar que nos tornamos quando somos visitados, pela negação, mantemo-lo como aquilo que nos indica sempre um além mais, um além do ente, do sentido ou de qualquer fundamento que determine acontecimentos e causas. Por isso, a descrição de Nabokov (1996) - que iremos expandir posteriormente - do rosto da mãe, em seu conto Terror, é-nos tão especialmente cara e alusiva: um rosto que pode ser redescoberto quando advém do espanto inominável do sem sentido e do horror! 
Estamos, assim, pensando que o acontecimento clínico significa estabelecer uma relação misteriosa com esse rosto ausente de sentido, que nos dignifica e nos responsabiliza com sua impessoalidade. Ser responsável pelo aparecimento desse rosto impessoal, dessa face ausente, parece ser aquilo que nos lança na miragem atordoante desse reflexo escuro de nossa imagem mais comum, ou seja, a possibilidade de nossa deposição para a constituição de uma comunidade heterônima indefinível.

Acaso Fernando Pessoa, o poeta, com seus setenta e dois nomes heterônimos, não nos legou essa visão profunda e comunitária? Essa visão não encontra eco naquilo que foi descrito por Safra (2004) como Sobórnost: a dimensão ontológica relativa à nossa "pan-unidade" originária? Eis uma concepção que parece advir da tentativa de permanecer diante daquela borda que pressente a diferença ontológica, a diferença entre ser e ente, como o lugar da escuta silenciosa do ruído daquilo que "há".

"O homem se encontra na fragilidade do entre: entre o dito e o indizível, entre o desvelar e o ocultar, entre o singular e o múltiplo, entre o encontro e a solidão, entre o claro e o escuro, entre o finito e o infinito, entre o viver e o morrer." (Safra, 2004, p. 24). A dimensão do "entre" parece ser aquela dimensão esquecida no pensamento clínico contemporâneo. Como poderíamos pensar uma clínica do "entre" que pudesse refletir o problema da singularidade justamente na sua conjunção com a multiplicidade? Por isso, o caminho para a possibilidade do reconhecimento de Sobórnost é amplo.

Do ponto de vista do paciente, ou do desenvolvimento infantil, poderíamos dizer que, para a deposição do eu mesmo, para o primado da representação do afastamento defensivo da alteridade, é necessário anteriormente que tenham sido possíveis uma criação ilusória da identidade do mesmo e a identificação com essa identidade. Ela parece que funda, em parte, a nossa experiência de sentir-se real, ou seja, sentir-se real parece ser oriundo da possibilidade dessa identificação com a identidade do mesmo e, simultaneamente, do reconhecimento da 
diferença existente nesse mesmo que é o eu. Parece, portanto, ser necessário inicialmente coroar o mesmo, para depois ampliá-lo, encontrando em si mesmo suas estranhas e inquietantes diferenças e desconhecimentos.

Wordsworth (citado por Britton, 2003) escreveu algo sobre o anseio pelo mesmo, possivelmente fazendo dele esse estado próprio da familiaridade do mundo:

Minhas esperanças não precisam mais mudar seu nome,

Anseio por um repouso que seja sempre o mesmo. (p. 107).

Esse mesmo não poderia ser também reconhecido como um aspecto da própria simetria e homogeneidade dos processos inconscientes? Desde Freud, a psicanálise dedica-se à tarefa de revelar como o desenvolvimento de nossa capacidade de pensar fundamenta-se na capacidade de tolerar a ausência do objeto e a existência da alteridade. Os estudos sobre o tema, em Freud, são muito amplos, mas derivam em parte da discussão que ele fez em seu trabalho Além do princípio do prazer (1920/2006e), em que descreveu pela primeira vez o jogo do carretel (fortda). Essa emblemática e arguta descrição fez com que a psicanálise dedicasse-se ao esclarecimento da ideia de a origem do desenvolvimento da capacidade humana ter contato com a realidade assimétrica, por meio da tentativa fantasiosa de se obter um controle onipotente sobre ela. Mas o autor também deixou seus leitores com a viva impressão de que haveria, nesse momento, a inauguração de algo importante do ponto de vista do desenvolvimento infantil, por meio do surgimento de uma capacidade de fazer com que o objeto pudesse permanecer logicamente idêntico a si mesmo e, ainda, íntegro e vivo.

Muito provavelmente, Freud (1920/2006e) baseou-se em algumas ideias de Nietzsche (1882/1978a), que, em A gaia ciência, procurou expor a tese de que a lógica, na mente humana, 
haveria de ter sua origem na não lógica. ${ }^{6}$ No entanto, para este autor, a não lógica parece ser a explicação da própria origem do ser humano, pois, para ele, essa origem, descomunal, deveria ser lembrada sempre que se pensasse em lógica e em início do nosso pensar. A sua origem não lógica é importante também como um modelo para entendermos o problema que levantamos, pois a lógica presente em nossa capacidade de pensar teria seu fundamento na aparente ausência da lógica presente na satisfação alucinada do desejo, que sabemos se tratar, na verdade, de outro tipo de lógica contraditória, que parece ser a de obter prazer e evitar o desprazer a qualquer custo; e nisso, certamente, também reside uma lógica.

Birksted-Breen (2005) coloca o assunto dessa maneira:

A ausência do objeto e o adiamento da satisfação forçam o ego a encontrar meios de lidar com essa experiência. A capacidade de reconhecer e de tolerar a frustração da ausência de objeto marca um estágio do desenvolvimento e se desenvolve junto com o sentido de tempo e com a capacidade de antecipar o retorno do objeto. No jogo fort-da (1920), a criança desenvolve o domínio simbólico sobre o período de tempo imprevisível que acompanha a perda do objeto. A simbolização e a linguagem nascem desse vácuo. (p. 222).

A autora continua seu trabalho dizendo que a criança, ao procurar conservar a representação do objeto, tentaria, na verdade, manter vivas a sua capacidade de representar e, consequentemente, a sua representação do próprio $e u$. No entanto, achamos importante ressaltar que há uma ideia nessa passagem muito importante: a de que a linguagem e a representação (que parecem ser consideradas num conjunto, como uma unidade) nascem do vácuo da perda do objeto. Então, ao representar o objeto, a criança estaria mantendo vivo para ela aquilo que teria ido embora, fundamentada em algo - e aqui parece ser importante - que se denominaria princípio de identidade, ou seja, que esse objeto é o mesmo ou igual àquele que se foi. Esse

\footnotetext{
${ }^{6}$ Não podemos nos esquecer de que, na História do movimento psicanalítico, Freud (1914/2006f) conta-nos que se negou o prazer da leitura das obras de Nietzsche, com o propósito de não prejudicar, com ideias antecipatórias, quaisquer ideias que pudessem ser descobertas ao longo de seus trabalhos ou da própria atividade clínica. Diz, ainda, que a investigação laboriosa clínica psicanalítica pode somente confirmar o que o filósofo reconheceu apenas por intuição, fazendo uma avaliação que, no entanto, demonstra certa leitura de suas obras.
} 
mesmo, nesse sentido, significa o reconhecimento da diferença desse objeto para com todos os demais, ou seja, a percepção de determinada diferença. O vazio ou o vácuo da ausência do objeto criaria, na criança, a necessidade de ter que lidar com um pensamento que se impõe, a saber: que, embora distante de sua sensorialidade, o objeto percebido mantém-se vivo e é o mesmo, idêntico àquele que retorna, pois se reconhece que o objeto que outrora satisfez e amou é o mesmo. Nessa diferença, ele se destaca do mesmo como a homogeneidade simétrica dos processos inconscientes.

Esse conhecimento ou atribuição da identidade do objeto ao objeto ausente (que retorna ou retornará) pode ser compreendido como fundamentado não apenas por uma lei do pensar, ${ }^{7}$ mas pela vivacidade de sua relação com a mãe, que o mantém familiar e que pode se manter existente mesmo a partir da ausência ou do vácuo. Nesse caso, não haveria simplesmente uma permanência do objeto idêntico a si mesmo, mas uma permanência afetiva de um sentimento de vivacidade, de existência, que seria reconhecido como tal. Nessa forma de compreender o problema, concebe-se o objeto - seja ele designado como seio ou como mãe - como uma presença que se perde, embora o que realmente se ausente, mas seja necessário se manter, seja o afeto e a expectativa atribuídos a ele; um afeto que explicita, possivelmente, uma necessidade preconceptiva: a necessidade de paternidade. O medo da perda, nesse caso, parece se confundir com o medo da perda da vivacidade, do afeto e da ilusão criada pelo objeto. ${ }^{8}$

A lógica assimétrica do reconhecimento da diferença parece incrivelmente nascer, portanto, da possibilidade de se conceber o mesmo, tendo como pano de fundo a possibilidade pressentida de sua ausência. ${ }^{9}$ Esse mesmo, no entanto, parece ser concebido como diferença

\footnotetext{
${ }^{7}$ O princípio de identidade, tal como concebido inicialmente por Aristóteles, formula que todo objeto é idêntico a si mesmo $(\mathrm{A}=\mathrm{A})$ ou, ainda, que uma coisa é o que é e não se confunde com nenhuma outra ou, ainda, que, consigo mesmo, cada objeto é ele mesmo o mesmo.

${ }^{8}$ Sobre esse assunto, não podemos deixar de nos lembrar de Winnicott (1958/1982a), em especial, de sua contribuição sobre os fenômenos e objetos transicionais e sobre a capacidade da criança de permanecer só, tema de trabalho que iremos nos aprofundar nos capítulos seguintes.

${ }^{9}$ É importante notar que Matte-Blanco (1975/1998) não deixou de conceber o inconsciente como um sistema em que haveria, além da lógica simétrica, também algo da lógica assimétrica. Chamou-o, assim, de bilógica, ou seja, de um sistema em que haveria preponderância e domínio da lógica simétrica, mas que, mesmo assim, haveria a
} 
pelo fato de surgir como desigualdade no campo de experiências emocionais simétricas infantis, experiências de homogeneidade dos conteúdos inconscientes. Aquilo que é o mesmo parece, assim, resguardar em seu íntimo esse aspecto da diferença, que repetidamente torna a experiência de viver desigual, separando, por exemplo, de si mesmo, um mundo "externo".

O fato de a criança saber que o objeto é o mesmo parece que se deve, portanto, a uma tolerância do sentimento de falta que a criança teve que lidar, o qual não só fez com que pudesse se perceber separada do objeto amado, como em risco, uma vez que suas capacidades relativamente precárias de poder lidar com essa falta poderiam levá-la, por exemplo, a retornar a uma tentativa de obter prazer de modo alucinado. De qualquer modo, descrevemos, assim, o aparecimento de uma passagem do outro em sua alteridade inicial como o reconhecimento do mesmo, como o reconhecimento da alteridade que destaca um objeto como dotado de afeto e vivacidade capazes de se prolongar em termos de expectativas ao longo de certo tempo; dessa forma, ele se conservaria como a primeira expressão de uma lógica assimétrica do pensar.

No entanto, o que parece ser relevante é a discussão mais pormenorizada do fato de a criança formular, na ausência do objeto, a igualdade dele no momento em que pode ressurgir dentro de seu controle onipotente. Isso se parece com a ideia formulada por Winnicott (1971/1975) de que a criança cria o objeto que estava lá para ser criado, porém, nessa criação, há a impregnação de uma identidade a esse objeto, a qual estava presente já quando era sentida a ausência desse mesmo objeto. No momento em que o objeto ressurge, há a certeza para a criança de que esse objeto é o mesmo e não outro. Sendo assim, esse objeto não pode ser e não ser ao mesmo tempo, ou seja, a criança concebe-o como um ser que é dotado de determinado afeto, de modo que ele não pode não ser ao mesmo tempo.

presença de aspectos da lógica assimétrica. O autor justifica a bilógica pela possibilidade de o inconsciente poder, por exemplo, conceber sinais, símbolos ou sonhos. A lógica assimétrica, própria da consciência, por sua vez, também teria uma forma lógica, em que se encontraria expressão da lógica simétrica, resultando, assim, uma descrição pelo autor da lógica bivalente. 
A importância disso decorre do fato de que a criança, na ausência do objeto, ao ter a experiência da falta e da sua ausência, formula esse objeto como algo que tem uma identidade e procura, após isso, no reaparecimento desse mesmo objeto, uma "confirmação" de que sua criação $(d a)$ está regulada por sua vontade onipotente. Note-se que, aqui, a onipotência faz parte do reinado da simetria, conforme apontou Matte-Blanco (1975/1998). O objeto criado não é o aparecimento da manifestação plena de surpresa, imprevisibilidade e diferença, mas a manifestação de uma lógica que surge em decorrência do estado de ausência do objeto, quando se concebe esse objeto como idêntico a si mesmo, ou seja, um objeto determinado que poderá ainda trazer satisfação, prazer, amor e a ilusão de uma repetição afetiva no porvir, que seja realizada e, assim, confirme a criação desse objeto concebido.

A questão que parece ainda estar no cerne do problema é o da capacidade humana de lidar com a ausência do objeto e de sua "real" impermanência, transitoriedade e mutabilidade. A criança parece criar um objeto que é o produto do reinado da simetria, mas visa, paradoxalmente, à assimetria. Podemos nos lembrar da criança insone, no silêncio ruidoso de seu quarto, pensando em seus pais, e em como esses pais podem se tornar para ela, no instante em que a imaginação cessa esse ruído, a expressão afetuosa que identifica e reconhece um rosto, após um momento de ausência em que o silêncio tornou-se demasiadamente volumoso. Nessa identificação, ela escapa do infinito, do "há" e, mesmo, do reinado da simetria. De posse da constituição de sua assimetria, na lembrança imaginária, a criança pode clamar por um nome, por um pai, que constitua a organização do seu mundo obscurecido pela ausência e pelo escuro da noite. Esse "pai” é também a concepção, ou seja, uma combinação entre uma preconcepção e uma realização (Bion, 1962/1994c). Mais adiante em nosso trabalho, trataremos dessas preconcepções como aspectos do Real, que aparecem sob a visitação da alteridade, na forma de um acontecimento. 
Essa tentativa de circunscrever a ausência de um fundamento é também tratada por Freud (1895/2006g, 1920/2006e) do ponto de vista das catexias de marcas mnêmicas infantis originais relativas ao objeto perdido. Mas, antes de adentrarmos nessa questão, vale a pena determo-nos um pouco mais sobre a necessidade da constituição, para o psiquismo, do mesmo. Parece que a memória, por sua vez, desempenha um aspecto importante nesse sentido; Freud (1912/2006a), por exemplo, ao falar sobre a imutabilidade de uma concepção, em Uma nota sobre o inconsciente na psicanálise, escreveu:

\footnotetext{
Uma concepção - ou qualquer outro elemento psíquico - que se ache agora presente em minha consciência pode tornar-se ausente no momento seguinte e, novamente presente, após um intervalo, imutada, e, como dizemos, de memória, não como resultado de uma nova percepção por nossos sentidos. (p. 279).
}

Nessa passagem, ele nos assinala que a memória pode ser também capaz de fazer com que um elemento psíquico possa, após um intervalo, aparecer novamente à consciência e, de maneira imutável, ser conhecido como o mesmo elemento de outrora. A ausência dele para a consciência não significa que tenha deixado de existir; parece que o ressurgimento de uma ideia ou de uma concepção em um momento posterior, que seja reconhecida como idêntica àquela do passado e que havia sido esquecida, pode acontecer pela identificação do mesmo. Mas a própria formação de uma concepção não nos revelaria a necessidade de pensarmos sobre esse reconhecimento do mesmo? Ele não ocorreria apenas por sua origem sensorial, mas possivelmente por ser proveniente também de preconcepções que são inerentes a nós? E essas concepções não teriam sua expressão justamente a partir desse vácuo, dessa ausência da presença do conceito? Ansiar por um pai, por uma mãe, por um “seio", não parece ser oriundo de uma preconcepção e, simultaneamente, não apareceria como anseio pela ausência daquele objeto que seria uma realização dessa preconcepção? Talvez possamos afirmar positivamente. Esse objeto que realizaria essa concepção talvez estivesse nessa realização, sendo a formação de 
um conceito, ou seja, do mesmo. Esse mesmo, assim, poderia permanecer como um referente, um nomeado, e se manteria no psiquismo como traço mnêmico. A memória parece, por isso, estar também associada a certo movimento de opacificação da mente, em que o passado pode tomar conta do momento presente. Como nos disse Bion (1967/2000a):

Reservo memória para a experiência relacionada predominantemente com as impressões sensoriais [...]. Não se deveria distinguir 'desejo' de 'memória'; prefiro tomar os dois termos como representantes de um mesmo fenômeno que é uma fusão de ambos. Tentei expressar isso dizendo que 'memória' é o tempo passado de 'desejo', sendo 'antecipação' seu tempo futuro. (p. 395).

Esse movimento de opacificação decorre do fato de que a memória é análoga ao desejo, no que diz respeito a uma espera por uma atitude do objeto com o qual se relaciona, de que ele será aquele mesmo que outrora trouxe determinada satisfação. Opacifica-se a mente porque, com a memória, deseja-se que determinado objeto inexistente esteja presente naquele momento, sem levar em conta a alteridade/diferença que já estaria, como possibilidade, mostrando-se.

O mesmo, além disso, pode ser concebido como um objeto inalterado do ponto de vista da possibilidade humana de transformá-lo pela introjeção, na forma de uma metabolização do estímulo que faça desse objeto material de uma imaginação criativa ou de um sonhar. Poderíamos dizer, nesse ponto de vista, que o mesmo é aquele objeto que se mantém impossibilitado de ser transformado pela mente, que desfaz sua mesmidade e o recria como multiplicidade.

Mas voltemos ao reinado da simetria do quarto da criança insone. Nessa ausência, que corresponde à presença do Real, nesse "há", não podemos dizer que há uma pura ausência. Quando ela aparece na análise, a ausência do rosto do analista, que pode ser redescoberto como o mesmo, escapa, na verdade, sempre da sua mesmidade e, ainda, não se deixa capturar pelos abrigos de sentido e de nomeação que cativam a interrogação, que é fundadora da pesquisa 
clínica. Poderíamos dizer, como Figueiredo (1997), que "há na alteridade do outro algo que me solicita, que me interpela, que me obriga, que me chama e me impõe uma responsabilidade.” (p. 44). A responsabilidade, pensamos, é o respeito por seu ultrapassamento transcendente, por sua remissão ao além do sentido e, com isso, por sua "eleidade" inominável.

Nesse sentido, as idealizações que se fazem do analista, como do suposto saber, podem ser observadas por meio da impossibilidade de tornar-se responsável por essa interpelação que nada diz de concreto, mas que nos depõe para nos reencaminhar para a solicitação de sua impessoalidade, de uma impessoalidade que nos reaproxima do outro, que se torna aquele pelo qual sou responsável, porque ele é a expressão do copertencimento no inominável. Assim, o movimento clínico da pesquisa sobre a realidade psíquica é marcado pelo encontro e desencontro, com o aparecimento desse "terceiro excluído", que, para Ogden (1996a), como sabemos, é designado como o "terceiro analítico":

O terceiro analítico não é apenas uma forma de experiência de que participam analista e analisando, é ao mesmo tempo, uma forma de vivenciar a eu-dade (uma forma de subjetividade), na qual (por meio da qual) analista e analisando se tornam outros do que foram até aquele momento. (p. 4-5).

Esse terceiro analítico, ou o terceiro excluído de Levinas (1997), apenas nos aponta para a dimensão de uma alteridade radical, para a qual somos chamados, quando podemos justamente escutar isso que nos vem ao encontro: o inominável. A presença desse inominável parece ser a origem do movimento de um dizer que não se esgota, não porque algo fique impossibilitado de ser dito, mas porque há sempre uma impossibilidade de tornar-se palavra algo que, como um retraimento, um impossível, uma ausência de registro, permanece inominável, muito embora - esse Real - possa ser, simultaneamente, pressentido como aquilo que "há". 


\subsection{Interpretação e Tradução}

As interpretações parecem ocorrer quando, em um momento de certa narrativa, o interlocutor dá-se conta de que há algo que estava sendo falado por alguém, que parece evocar justamente uma presença que se mostra ausente: espécie de personagem que não havia ainda encontrado um ator para representá-la e que, por isso, não havia ainda sido narrada e examinada; ou, ainda, uma alteridade que não poderia ser reconhecida, uma vez que seu aparecimento criaria a iminência de um surpreendente assombro, de uma vertiginosa mudança, que poderia implicar, como em Édipo Rei, uma visão absolutamente diferente sobre o eu mesmo. As interpretações são modos de evocação ou de figuração dessa alteridade.

Há em Levinas (1980/1988), em seu livro Totalidade e infinito, a evocação dessa alteridade, ao falar sobre a posse do filho pelo pai; ele nos diz:

\footnotetext{
Nos escritos de juventude, Hegel pôde dizer que o filho é os pais; e em Weltater, Shelling - por necessidades teológicas - soube deduzir a filialidade da identidade do Ser. A posse do filho pelo pai não esgota o sentido da relação que se realiza na paternidade em que o pai se reconhece, não apenas nos gestos de seu filho, mas na sua substância e na sua unicidade. O meu filho é um estranho (Isaías 49), mas que não é apenas meu, porque é eu. É eu estranho a si. (p. 245).
}

Nessa passagem, Levinas (1980/1988) apresenta-nos a ideia de que a descoberta do $e u$, no filho, é a descoberta de um outro. Esse outro, descoberto na face simultaneamente familiar, é o estranho de si mesmo, é aquela face que não se exprimiu até então, além de uma ausência de registro, de uma falta de reconhecimento de sua fecundidade radical, pois o pai, que pode encontrar-se nessa radicalidade, também é aquele que, na face do filho, descobre que se encontra não apenas com um além da filiação, mas com aquilo que é, acima de tudo, existente e inabarcável para ambos. Isso está para além do que o filho pode reconhecer de si mesmo e para além daquilo que o pai pode ser ou reconhecer de si mesmo, ou como um traço familiar ou 
como um traço que lhe é conhecido. Há, parece-nos, a formação de um terceiro excluído, de um mais além perturbador, que não é somente o germe daquilo que virá, como o possível do futuro, mas aquela radical diferença inominável do até então testemunhado. Ogden (1996a) explicitounos isso com sua descrição do terceiro analítico:

O confronto com a alteridade não nos dará descanso; essa percepção da eu-dade, uma vez registrada, não nos permitirá permanecer quem éramos e não poderemos descansar até termos de alguma forma aceitado seu ataque ao que fôramos antes de sermos interrompidos por ela. (p. 3).

No trabalho analítico, estamos enfrentando constantemente o problema da filiação de nossas ideias e das ideias de nossos pacientes. O trabalho analítico, por vezes, pode reconhecer a estranheza de seu paciente como expressão da estranheza de si mesmo no outro. Certamente, essa estranheza produz sentimentos de insegurança que o analista pode querer atenuar, alienando-se desse encontro fecundo com o pensamento, que é uma expressão do nascimento daquilo que é o prenúncio do impensável. No entanto, a tarefa psicanalítica não parece ser a de produzir um filho que seja a face do pai ou um paciente que reproduza as teses de determinada teoria; parece ser, antes, dar à luz o filho que é além do pai (analista) e que revela a sua alteridade desconhecida e, por vezes, irreconhecível. Assim, permanece, para ambos, como uma questão interminável cujo devir deverá ainda transformá-la em uma missão pertencente ao futuro indeterminado: a tarefa psicanalítica deve poder resguardar esse futuro aberto.

Diante dessa radicalidade em que o trabalho analítico pode ser compreendido, apreendemos pela interpretação certas ideias, afetos ou pensamentos que foram esquecidos ou recalcados pela ação defensiva. A interpretação, portanto, pode ser descrita também como aquela atitude transformadora que, por meio de palavras ou atos, faz revelar certo pensamento onírico inconsciente, geralmente de origem sexual, que lá estava presente sem que pudesse ser pensado e, simultaneamente, apreendido ou tornado parte da personalidade de alguém. O modo 
como ela é feita depende sempre da transformação lógica realizada pelo analista da combinação de pensamentos simétricos para um pensar assimétrico; por isso, ele deve ser, simultaneamente, um tradutor. Certamente, ser um tradutor dessa lógica não implica ser um traidor de sua fonte, nem ser absolutamente fiel a ela, pois interpretar, nesse sentido, pode ter também o sentido de construir aquilo que dará um sentido e esclarecimento sobre a questão que parece ser intrigante e inominável em sua inteireza, o "conjunto" simétrico palimpséstico de pensamentos oníricos inconscientes. Aliás, o sentido da tradução parece se basear em um pressuposto paradoxal: traduz-se aquilo que, em sua origem, é desconhecido e pressentido como inominável, mas, pela ação da tradução interpretativa, isso se tornaria conhecido ou nomeado e, possivelmente, parte da personalidade do analisando, agora unido e encarnado ${ }^{10}$ em sua personalidade esse aspecto outrora desconhecido.

Em seu trabalho Esboço de psicanálise, Freud (1940/2006h) escreveu sobre os processos incognoscíveis do seguinte modo:

A realidade sempre permanecerá sendo 'incognoscível'. O rendimento trazido à luz pelo trabalho científico de nossas percepções sensoriais primárias consistirá numa compreensão interna (insight) das ligações e relações dependentes que estão presentes no mundo externo, que podem de alguma maneira ser fidedignamente reproduzidas ou refletidas no mundo interno de nosso pensamento, um conhecimento das quais nos capacita a 'compreender' algo no mundo externo, provê-lo e, possivelmente alterá-lo. O nosso procedimento na Psicanálise é inteiramente semelhante. Descobrimos métodos técnicos de preencher as lacunas existentes nos fenômenos de nossa consciência e fazemos uso desse método exatamente como um físico faz uso da experiência. Dessa maneira, inferimos um certo número de processos que são em si mesmos 'incognoscíveis' e os interpolamos naqueles que são conscientes para nós. E se, por exemplo,

\footnotetext{
${ }^{10}$ Torna-se importante notar que Bataille (2003) cunhou essa mesma expressão para designar formas desconhecidas que se impõem ao familiar, ao conhecido e ao homogêneo, dando a eles uma expressão e sentido que se ampliam e desagregam essa homogeneidade. Em História do olho, seu romance proscrito e assinado sob a forma de um pseudônimo, o autor convida-nos a ser lido como uma máscara, uma obscura encarnação do caos, que comunicaria a incerteza e a ameaça de mudanças súbitas, tal como nos sugere Moraes (2003) ou como nos diz Barbosa (2000), ainda comentando o pensamento de Bataille: "O heterogêneo é aquilo que está definitivamente colocado fora da esfera do conhecimento científico. Ora, a ciência procede segundo uma lógica que a obriga a estabelecer identidades, a reconduzir o outro ao mesmo. Como seria então possível fundar uma ciência do que é irredutível à identidade? Do Outro só podemos ter a experiência, porque ele não é cognoscível” (p. 84) e desse Outro teríamos a encarnação de suas formas informais, caóticas.
} 
dizemos: 'Neste ponto, interveio uma lembrança inconsciente', o que queremos dizer é: 'Neste ponto, ocorreu algo de que nos achamos totalmente incapazes de formar uma concepção, mas que se houvesse penetrado em nossa consciência, só poderia ter sido descrito de tal e qual maneira.' Nossa justificação por fazer tais inferências e interpolações e o grau de certeza que a elas se liga naturalmente permanecem abertos à crítica em cada caso individual, e não se pode negar que com frequiência é extremamente difícil chegar a uma decisão - fato que encontra expressão na falta de concordância entre analistas. (p. 210).

Nessa citação, chama-nos a atenção a prerrogativa de que inferimos certo número de processos que são, em si mesmos, "incognoscíveis" e os interpolamos naqueles que são conscientes para nós. Freud (1940/2006h), nessa passagem, refere-se certamente à ação da interpretação, mas de um modo que deixa o seu leitor intrigado com o processo que é descrito por ele, pois fazer uma inferência ou uma interpolação certamente não parece dar a ela a validade de um modo pelo qual se possa apreender, pela interpretação, um processo psíquico verdadeiro, uma vez que essa verdade pareceria apenas ser algo que não parece poder ser conhecido, apenas inferido ou interpolado.

Entretanto, em um dos seus trabalhos sobre técnica psicanalítica, Freud (1912/2006i) descreve o processo interpretativo de modo diferente, de um ponto de vista analógico:

Ele [o analista] deve voltar seu próprio inconsciente, como um órgão receptor, na direção do inconsciente transmissor do paciente. Deve ajustar-se ao paciente como um receptor telefônico se ajusta ao microfone transmissor. Assim como o receptor transforma de novo em ondas sonoras as oscilações elétricas na linha telefônica, que foram criadas por ondas sonoras, da mesma maneira o inconsciente do médico é capaz, a partir dos derivados do inconsciente que lhe são comunicados, de reconstruir esse inconsciente, que determinou as associações livres do paciente. (p. 129).

Nessa analogia telefônica, descreve sobre a possibilidade técnica da utilização do inconsciente do analista como instrumento de análise. Essa utilização deve proporcionar um modo de apreensão do inconsciente do paciente, através dos seus derivados do inconsciente, ao 
ser realizada uma transformação desses derivados, no modo de uma reconstrução. Essa transformação, descrita por meio da analogia com o receptor telefônico, mostra-nos como Freud (1912/2006i) concebia a interpretação como uma tentativa de recepção e de transformação de determinada fonte. Essa fonte, ou seja, determinado processo inconsciente em que há determinado pensamento onírico recalcado, no entanto, não é absolutamente incognoscível, pois é também expressão de certo determinismo psíquico, encontrado por meio das associações livres do paciente, ou seja, de palavras, sons ou quaisquer outras expressões que possam ser apreendidas sensorialmente pelo analista.

Freud (1912/2006i) parece nos indicar, por um lado, que a interpretação deveria poder reconstruir a origem da associação, tornando essa reconstrução a mais fiel possível do pensamento original, e, por outro lado, que as interpretações parecem ser inferências e interpolações, em face das lacunas que se formam por sermos incapazes de formar uma concepção a respeito delas. Parece, portanto, como o autor sugere, que uma interpretação, por mais que tente ser uma reconstrução do original, não poderia ser uma reconstrução exata dessa fonte, uma tradução absolutamente fiel, no sentido de que uma interpretação talvez não possa jamais - ser uma tradução fiel. Ela parece se assemelhar, assim, a uma reconstrução por meio de evidências, uma reconstrução de oscilações elétricas em ondas sonoras, ou a uma transformação.

As interpretações têm a característica de nunca serem equivalentes à sua fonte inconsciente. Esse pressuposto, tal como formula Priel (2005), indica-nos que, para que possa ser realizado o trabalho da interpretação ou da realização de uma tradução de uma fonte inconsciente para um alvo consciente, é necessária uma significativa modificação. A realização dessa modificação ou dessa reconstrução mostra-nos que aquilo que foi traduzido não é uma cópia exata da fonte, mas uma alteração necessária para que os pensamentos oníricos 
inconscientes pudessem ser expressos satisfatoriamente para outro modo de organização do pensar. Trata-se, assim, de poderem ser expressos por meio de relações assimétricas.

Nessa atividade de tradução interpretativa, não fazemos com que somente o material inconsciente possa ser compreendido pela consciência, mas que seja preenchido do sentido daquilo que está sendo omitido e, assim, constituída uma sequência lógica de eventos que torne o conteúdo, outrora incompreensível, compreendido, ainda por conta de uma série de eventos complementares proporcionados pela associação livre (Freud, 1900/2006b, 1937/2006j). Tratase para alguns comentadores, como Ogden (1996a), de uma relação dialética entre consciência e inconsciente ou, como Freud (1915, citado por Ogden, 1996a) disse: "em si e por si (os processos inconscientes) não são cognoscíveis, são inclusive incapazes de levar a cabo sua existência (independente do sistema pré-consciente-Consciente).” (p. 16); ou ainda, como nos $\operatorname{diz}$ Priel (2005):

Além disso, Freud viu a repressão como uma 'falha de tradução' que evita o desprazer. Tal falha caracteristicamente interrompe a criação presumida de séries de transcrições ou traduções de conteúdos psíquicos em formas mais maduras (Carta 52, 1886, p. 175). Às vezes, a tradução intrapsíquica se dá na direção oposta, como no caso das lembranças encobridoras, onde os traços de memória são transformados em imagens visuais $(1899$, p. 321). Em todas estas referências à tradução, Freud enfatizou sistematicamente a diferença inerente que sempre remanesceu entre os modos de expressão da fonte (inconsciente) e do alvo (consciente). A tradução nunca é, portanto, equivalente à sua fonte. (p. 247).

Os processos de pensamento assimétricos, próprios do processo secundário e característicos de nosso pensar consciente e racional, são, desse modo, processos de transformação e de tradução que ocorrem também, de modo geral, ainda em obediência ao princípio do prazer. As falhas de tradução teriam como objetivo somente a tentativa de manutenção de certo grau de evitação do desprazer. Podemos pensar que o trabalho de autoanálise de $A$ interpretação dos sonhos (Freud, 1900/2006b) encontra-se justamente na 
direção de realizar uma "correção" dessas falhas de tradução que a repressão inevitavelmente faz no psiquismo e, assim, aparecem para a linguagem da consciência como algo incompreensível e absurdo, enquanto sua origem diz respeito àquilo que não pode ser apreendido pela consciência pelo trabalho da resistência. Podemos notar, no entanto, as dificuldades encontradas nessa tarefa corretiva, como, por exemplo, em Sonho da monografia de botânica, em que o autor parece descrever justamente sua dificuldade pessoal de fazer, em sua autoanálise, essas correções. ${ }^{11}$

Mas o analista, nesse sentido, como um tradutor dos processos psíquicos inconscientes de seu analisando, parece originário de um desdobramento inevitável e necessário da autoobservação e autoanálise do próprio Freud (1990/2006b). Sua atitude perante seus próprios pensamentos oníricos legou-nos a máxima de que os processos subjacentes são realizações de desejos inconscientes, processos que não temos acesso senão por meio de uma atitude de observação e de interpretação. Essa observação teve, sem dúvida, a auto-observação e a interpretação, ou seja, a tradução daquilo que ele via em si mesmo e que era reconstruído na forma de uma correção, como sua origem.

Freud (1900/2006b) demonstra-nos que a auto-observação e, posteriormente, a possibilidade de realizar livremente uma associação sobre o material dos sonhos fornecem ao sonhador a possibilidade de encontrar um sentido oculto presente no interior dos pensamentos oníricos. As traduções do discurso do analisando poderiam ser compreendidas como modificações do desejo inconsciente, pois Freud (1900/2006b) manteve-se como um tradutor que compreendia o material inconsciente como fonte inesgotável de sentido. Assim, o processo

\footnotetext{
${ }^{11}$ Freud (1900/2006b), em A interpretação dos sonhos, quando discute sua célebre interpretação do Sonho da monografia de botânica, em determinado momento, após associar livremente, parece justamente se abster da constatação de seus próprios conteúdos sexuais de caráter erótico relacionados com a paciente com quem sonhara; assim, interrompe a interpretação bruscamente. Tratou-se, provavelmente, de uma relação na qual Freud havia possivelmente percebido que havia prometido algo que, para sua paciente histérica, não seria possível dar ou, se desse, não poderia posteriormente manter-se como médico. De qualquer modo, torna-se muito interessante nesse relato, por exemplo, sua descrição, que revela seu desejo por observar dentro da paciente seus órgãos genitais, que, de algum modo, seriam a própria sexualidade da paciente. Talvez a observação da vida sexual tenha ocorrido como um modo de transformação do desejo de observação daquilo que há dentro da paciente, seus próprios órgãos sexuais.
} 
de tradução não pode ser compreendido simplesmente como uma adequação do intelecto ao material psíquico inconsciente e uma correspondência entre ambos, mas como uma atitude interessada por criar uma forma, dar uma explicação e um esclarecimento, e reconstruir esse material, ou seja, como um exame em que se quer dizer algo sobre aquilo que está ausente, inapreensível, sem que se tenha como premissa que isso será conceitualizado ou nomeado diretamente ou ainda que, por meio de uma interpretação, o pensamento onírico torne-se inteiramente esclarecido.

Há presente, na ideia da tradução, a permanência de um centro fugidio, que necessariamente escapa à tradução, pois interpretar significa "atribuir um sentido - isto é, substituí-lo [o sonho] por algo que se ajuste à cadeia de nossos atos mentais como um elo dotado de validade e importância iguais ao restante." (Freud, 1990/2006b, p. 131). Essa interpretação, como sabemos, aplica-se não apenas ao sonho, mas também a outras produções do inconsciente, ou seja, seus derivados, que surgiriam dessa fonte, como a estranha manifestação de atos falhos, sintomas etc. O elo é, portanto, aquilo que promove a continuidade de uma narrativa inacabada, que pode ir sendo "corrigida" para que mantenha seu foco tanto no sentido proferido quanto no porvir, no ponto ausente do discurso.

O conhecimento do inconsciente compreendido como qualidade apenas parece poder ser obtido em circunstâncias nas quais, invariavelmente, uma transformação pudesse ser efetuada para a consciência. Freud (1900/2006b), assim, entendia que o inconsciente não seria acessível senão por meio de uma modificação, na qual, por oposição, algo deixaria inevitavelmente de ter essa qualidade. A consciência, desse modo, apenas lidaria com fenômenos conscientes, que poderiam ser apreendidos como pertencentes ou a uma realidade mental ou a uma realidade exterior, dependendo, inclusive, dos mecanismos de repressão, mas fenômenos conscientes que são dotados da possibilidade de serem surpreendentes, de criarem estranhamento e de aparecerem como marcas da alteridade. Essa fundamentação do fenômeno como pertencente a 
uma ordem incognoscível certamente foi promovida pela influência que parece ter recebido de Kant, que foi o primeiro a afirmar que a razão humana era limitada para a apreensão da realidade última. O conhecimento, e o conhecimento do inconsciente, poderia se referir apenas aos fenômenos e não às coisas em si, que, embora possam ser consideradas reais, permaneceriam para nós incognoscíveis (Kant, 1787/1994) ${ }^{12}$.

Essa concepção do inconsciente como realidade última, inacessível, incognoscível e indefinível é certamente explicitada por Freud (1900/2006b), como vimos, e desenvolvida também por diversos psicanalistas, entre os quais Bion (1962/1994c, 1965/2004a), que expandiu significativamente esse problema, legando-nos, entre outras proposições, a de que essa realidade deveria não apenas ser conhecida, mas ser tornada parte da personalidade, de modo a ser encarnada pelo analisando. Grotstein (2010), ao relembrar sobre o início desse pensar bioniano, em que pela primeira vez formulou a ideia de fatos absolutos - de "O" -, diznos que Bion havia "atravessado o rubicão da respeitabilidade psicanalítica em Londres e iniciou uma revolução metapsicológica cujos ecos ainda estão repercutindo no panorama psicanalítico mundial.” (p. 123). Tal passagem a que se refere encontra-se em Transformações (Bion, 1965/2004a), muito embora possamos dizer que essa ideia já estivesse presente, mas ainda não escrita, desde 1962, na sua Uma teoria sobre o pensar (Bion, 1962/1994c). Nesse trabalho, o autor formula a ideia de um pensar e de um aparelho de pensar que surgiria para poder dar conta dos pensamentos, que teriam um estatuto ontológico, distinto do pensar. Essa ideia expressa tanto a independência dos pensamentos em relação ao pensar quanto que esses pensamentos (“O”) prescindem de um pensador, ou seja, o pensar passaria a existir para dar conta dos pensamentos. A passagem referida é a seguinte:

\footnotetext{
${ }^{12}$ Kant (1787/1994) desenvolve, no Prefácio da segunda edição da crítica da razão pura, o seguinte pensamento: "Não podemos ter conhecimento de nenhum objeto enquanto coisa-em-si, mas tão somente como objeto da intuição sensível, ou seja, como fenômeno; de onde deriva, em conseqüência, a restrição de todo conhecimento especulativo da razão aos simples objetos da experiência. Todavia deverá ressalvar-se e ficar bem entendido que devemos, pelo menos, poder pensar esses objetos como coisas-em-si embora os não possamos conhecer.” (p. 25).
} 
Será que esta teoria [a teoria das transformações] pode ser aplicada para interligar as preconcepções psicanalíticas, e os fatos conforme emergem durante a sessão? De início aplicarei a teoria ao meu próprio relato da sessão. Algo ocorreu durante a sessão. Nunca se pode conhecer os fatos absolutos, que simbolizo pelo sinal O. Minha descrição é como agora os fatos parecem ter sido no momento em que ocorreram. (Bion, 1965/2004a, p. 31).

No entanto, algumas linhas antes, Bion (1965/2004a) já havia indicado o parentesco dessa ideia com a de Kant (1787/1994) ao dizer:

Uma ilustração pode esclarecer o uso destes símbolos: o paciente entra na sala e, seguindo uma convenção estabelecida na análise, cumprimenta o analista com um aperto de mãos. Isto é um fato externo, aquilo que denominei uma 'realização'. Na medida em que seja útil considerá-lo como uma coisa em si e incognoscível (no sentido de Kant), é representado pelo símbolo O. (p. 28).

Sandler (2005a) refere-se a essa grafia como um "símbolo quase matemático criado para denotar a realidade do nômeno do inconsciente, onde a verdade humana e individual residem, como a realidade última, a verdade absoluta.” (p. 527). Trata-se, segundo o autor, de uma notação referente à experiência não sensorial, às formas ideais de Platão, e que corresponde simultaneamente à origem (“O”), tal como descrito por Bion (1965/2004a), em Transformações.

De qualquer modo, não seria imprudente dizer, tal como Freud (1940/2006h), que a limitação da psicanálise, bem como de qualquer ciência, seria a de não saber sobre essa realidade última, nem com o desenvolvimento de meios artificiais de apreensão dos fenômenos, pois eles seriam, para nossa mente, sempre fenômenos e nunca a própria coisa, a coisa em si mesma; Bion (1965/2004a) certamente comungaria dessa ideia. A tradução ou interpretação aparecerá, portanto, como uma importante ferramenta de trabalho da psicanálise, por poder reconstruir aquilo que está, justamente, avesso, retraído e indisponível ou que seria um em si incognoscível. No entanto, ao fazermos uma interpretação, mesmo assim parece que 
continuaremos lidando apenas com fenômenos derivados do inconsciente, mesmo ao transformarmos esse retraído e indisponível em palavras que pretendem traduzir o incompreensível e inominável, visto que não se conseguirá esgotar, pela palavra, esse inominável, que parece se manter como uma abertura de possibilidades de sentido ainda não nomeadas.

O termo 'interpretação', como nos mostra Laplanche e Pontalis (2004), tanto em francês quanto em português, não se ajusta exatamente ao termo alemão - original -, que é Deutung. Esse termo alemão designa mais um sentido de explicação e de esclarecimento e consiste em determinar a sua Bedeutung, ou seja, a sua significação. Mas em que medida a interpretação fornece-nos, de fato, uma significação? Não seria essa significação também marcada pela impossibilidade de dizer a significação por inteiro? Freud (1900/2006b) já havia indicado isso ao dizer:

Assim, o método de interpretação dos sonhos que pratico já difere, nesse primeiro aspecto importante, do popular, histórico e legendário método de interpretação por meio do simbolismo, aproximando-se do segundo método, ou método de 'decifração'. Como este, ele emprega a interpretação en détail e não en masse, como este, considera os sonhos, desde início, como tendo um caráter múltiplo, como sendo conglomerados de formações psíquicas. (p. 138).

A diferença entre essas duas formas de interpretação reside no fato de Freud (1900/2006b) entender que haveria cadeias de pensamentos oníricos presentes simultaneamente em nosso psiquismo e que o método de interpretação dos sonhos precisaria levar em conta que cada aspecto do sonho estaria, muito provavelmente, sendo a expressão de uma dessas camadas de cadeias de pensamentos inconscientes. Desse modo, não seriam necessárias as interpretações que procurassem o sentido total do sonho ou reconstruíssem um único sentido para o sonho inteiro, uma vez que, de modo geral, os sonhos precisariam ser interpretados de modo "fracionado", ou seja, interpretada cada camada, cada "fração" de pensamento onírico. A 
interpretação que determina sua significação haveria, assim, de ter que compreender essa questão e o sonho inteiro poderia, por essa razão, ser apenas uma construção posterior do sonhador, um modo de organização do sonho a posteriori, visto que ele seria composto de múltiplos pensamentos e afetos inconscientes não necessariamente articulados entre si. Sem dúvida, podemos afirmar que a construção posterior também parece ser uma organização de um sentido do sonho, que não é simplesmente o de dissimular e esconder conteúdos recalcados.

Diante da constatação da presença desse inominável, mesmo após uma interpretação que nomeie verdadeiramente certo pensamento onírico inconsciente, para nós a pergunta heideggeriana sobre o sentido do "Ser" parece-nos análoga àquela que podemos fazer agora sobre o inconsciente, pois, ao tentarmos falar sobre o inconsciente, não estivemos, até agora, apenas revelando diversos sentidos conscientes? Haveria como poder pensar no inconsciente sem torná-lo entificado por uma proposição? Heidegger (1927/1997), em seu famoso trabalho Ser e tempo (Sein und Zeit), mostrou-nos que sua interrogação sobre o sentido do "Ser" deve, no entanto, ser apreendida não apenas como uma questão do filósofo, mas como uma questão que está no interior de toda a filosofia, como uma questão fundamental, cujas origens datam do início de um pensar filosófico.

A psicanálise, não opostamente, mas trilhando caminhos paralelos, também irá se deparar com essa mesma pergunta e, em especial, sobre como parece ser inviável obter alguma definição totalizante e entificada sobre "Ser", sobre o inconsciente ou sobre o "Real". No entanto, a perspectiva dessa inviabilidade não deve nos impedir de formular a pergunta sobre o seu sentido, mesmo sabendo que a resposta deverá se manter sempre inacabada ou aberta, ou seja, inconclusiva e disponível à presença da indeterminação. Isso parece que já é, por si só, uma alteração do pensamento kantiano. Ao longo deste trabalho, iremos justamente pensar em que medida essa concepção kantiana da coisa em si parece não ser um modelo absolutamente adequado para o desenvolvimento do pensamento bioniano sobre a realidade última, sobre "O". 
Parece ser, portanto, um propósito desnecessário e empobrecedor dar uma definição para algo que se preconiza ser simultaneamente indefinível: uma redução do heterogêneo para a homogeneidade. Contudo, mesmo indefinível, isso permanece sendo, ainda assim, a mola propulsora para a pergunta sobre ele mesmo, uma vez que podemos dizer que "Ser" não pode ser definido como um ente e "não pode ser objeto de determinação predicando dele um ente." (Heidegger, 1927/1997, p. 13). Assim, “Ser” não pode ser confundido com ente, ou seja, um predicado; e pensamos que poderíamos fazer a mesma afirmação sobre o inconsciente e sobre o Real. Desse modo, aquilo que poderemos obter como resposta, ou seja, como reconstrução do sentido de um pensamento, jamais poderá nos alienar da fonte da interrogação ou da própria interrogação, que pode manter o pensar sempre em curso, tendo em vista tanto o aparecimento do sentido outrora inconsciente e a presença do desconhecido quanto o ponto em que ainda "há" tanto para se tornar palavra.

Freud (1915/2006k), em especial, em seu artigo $O$ inconsciente, formula o inconsciente com um sistema qualitativo de origem topográfica, caracterizado como: $\left(1^{\circ}\right)$ atemporal; $\left(2^{\circ}\right)$ aespacial; $\left(3^{\circ}\right)$ desprovido de negação; $\left(4^{\circ}\right)$ desprovido do princípio de não contradição; $\left(5^{\circ}\right)$ produtor de deslocamento e condensação; $\left(6^{\circ}\right)$ organizado pelo funcionamento do processo primário; e $\left(7^{\circ}\right)$ indistinto em relação às realidades interna e externa. Dessas características, algumas dizem respeito a algo que não é da ordem da consciência, portanto seriam caracterizações negativas ou opositivas da consciência, e outras seriam observações da ocorrência de certa característica do inconsciente, que, sendo necessariamente parcial, não se presta à definição do todo. Assim, podemos entender que a explicitação do que algo não é não o caracteriza inteira e positivamente, e que a enumeração de suas qualidades parciais não o caracteriza inteiramente. Com isso, pretendemos dizer que o inconsciente freudiano não pretende ser um sistema, uma qualidade ou um conteúdo definido. 
Desse modo, talvez possamos dizer que caracterizar o inconsciente como coisa em si, ou "O",13, parece ter sido o modo pelo qual se procurou manter o inconsciente como uma questão, por meio da qual se faz persistir simultaneamente certa determinação e certa indeterminação, e, consequentemente, certa instabilidade para a consciência, que, vagamente, apreende a lógica simétrica do pensar. ${ }^{14}$ Podemos entender, assim, que reside, nessa caracterização do inconsciente, uma impossibilidade de defini-lo como um ente, pois o inconsciente parece sempre escapar de uma predicação. Logo, parece ser análogo ao que era, por exemplo, Physis para os gregos: a "forma primeira de manifestação do ser, ou de sua presença" (Vaz, 1993, p. 11) e, portanto, algo indemonstrável, embora possa ser descrito. Poderíamos falar, desse modo, como nos diz Blanchot, numa frase que Bion (1963/2004b) gostava tanto de repetir, que $a$ resposta é o adoecimento da questão (ou que a resposta é a doença que mata a curiosidade).

Com esse sentido, podemos dizer que o inconsciente é constantemente produtor de interrogação, de questão e curiosidade, por meio dos pensamentos oníricos inconscientes que estariam inevitavelmente, por meio de seus derivados, apenas relativamente presentes para a consciência incapaz de compreendê-los inteiramente; um inconsciente que parece ser um produtor de interrogação para a consciência e para seu pensar assimétrico, que luta para se entender. Parece que a revolução que a psicanálise trouxe para a cultura é marcada por essa visão perturbadora: a existência perene da alteridade no eu mesmo, que nos assombra com esse outro que "há" em nós e que se revela, inicialmente, como uma massa homogênea de pensamentos oníricos inconscientes.

Freud (1915/2006k), ainda nesse trabalho, representa-nos o inconsciente de um ponto de vista tópico, dinâmico e econômico. Haverá, como tópos, como um lugar psíquico, um destaque, por procurar evidenciar a distinção entre ele e a consciência. Cada um dos sistemas

\footnotetext{
${ }^{13}$ O, para Bion (1965/2004a), é o desconhecido e incognoscível, designado de múltiplas formas, como, por exemplo, "deidade", "divindade", "coisa em si", "realidade última", "verdade absoluta", "inconsciente não reprimido", "pensamento sem pensador" etc.

${ }^{14} \mathrm{Ou}$, mais exatamente, conforme vimos, uma bilógica.
} 
possuiria um modo próprio de funcionamento mental, denominado processos primário e secundário. O que se encontraria nesse sistema inconsciente, nesse tópos, seriam representações inconscientes recalcadas ou pensamentos oníricos impossibilitados de regressar à consciência, vestígios de pensamentos e reminiscências, mas, além deles, haveria outro tipo de representação, fundamentalmente aquela representação que ele denominará representação de coisa (Dingvorstellung). Trata-se de uma formulação complexa em Freud (1915/2006k).

A representação de coisa consiste em originários investimentos (catexias) nos objetos; as primeiras catexias objetais, que seriam compostas por certos traços mnêmicos desses primeiros objetos. Trata-se da inscrição de um acontecimento, o qual, embora ocorrido e, dessa forma, possuindo um traço mnêmico, um traço original, não será análogo a nenhuma representação posterior e, por isso mesmo, será irrepresentável, ou seja, ele encontrará na representação de palavra sua possibilidade essencial de expressão e consumação como representação para a consciência. Apenas eventos posteriores, outros traços mnêmicos, poderão significar, sempre parcialmente, essa inscrição original, reavivando-a e reinvestindo-a (Laplanche \& Pontalis, 2004), ou seja, nenhum fenômeno consciente conseguiria caracterizá-lo inteiramente. Trata-se, portanto, da inscrição de um acontecimento originário, de traços mnêmicos que seriam apenas reavivados quando fossem posteriormente reinvestidos, mas o seu reavivamento não pareceria poder formular lembranças ou imagens figuradas, senão como "releituras", representações posteriores.

Assim, sabemos que a representação de coisa não se assemelharia a uma coisa, tal como compreendemos ser uma coisa, ou seja, um objeto que tenha determinada identidade, seja idêntico a si mesmo em sua apresentação como ente, seja ele fenomênico, ideacional ou imaginário, uma vez que a representação de coisa freudiana parece nos convidar a pensarmos sobre uma inscrição mnêmica que em nada tem a ver com qualquer traço mnêmico de registro consciente, no qual se fazem presentes as leis do pensar, tal como o princípio de não 
contradição e o princípio de identidade - formas de um pensar assimétrico. Mesmo assim, Freud (1915/2006k) compreende-a como aquilo que escapa de sua possibilidade de apreensão, como uma catexia, de uma inscrição e representação imagética, que é a origem de toda e qualquer relação objetal posterior. Não se trata de algo, de uma imagem, que possa de algum modo tornar-se consciente, o que valeria somente para um conteúdo recalcado (Verdrängung); trata-se, anteriormente, de uma estrutura positiva, que tem como característica primordial ser sistemática ou originária de um sistema (Garcia-Rosa, 2007). A partir desse sistema inconsciente, parece poder haver uma trama de representações, de afetos, de pensamentos oníricos inconscientes e de recalques, mas isso parece ser posterior ao fato de haver se estabelecido o próprio inconsciente por meio dessa inscrição original. Há, portanto, um recalque originário, uma demarcação até então indiferenciada ou:

uma inscrição acompanhada de uma fixação da pulsão numa representação ou conjunto de representações. Essa inscrição não se dá num inconsciente recalcado, posto que ele ainda não existe, embora ele seja inconsciente. A partir de então, o que sequer era do domínio da significação (e tampouco da verbalização) começa a ser integrado numa rede de oposições significantes, formando um sistema - o inconsciente - como uma trama de representantesrepresentação. Essa rede ou trama integra retroativamente o passado anterior ao recalque ao mesmo tempo que constitui o recalcado. (Garcia-Rosa, 2007, p. 204).

Precisamos, assim, compreender que as tramas ou tessituras dessa rede de oposições inconscientes são simultaneamente a face dessa inscrição original, desse recalque original, que, no entanto, é uma inscrição sem face alguma. Essa ausência de face do recalque original é também a expressão de uma fixação da pulsão, a qual fundamenta um sistema ou cria a possibilidade para que aconteça essa trama que se tece de modo simétrico, mas essa tessitura dá-se justamente diante da ausência da face do recalque original, tal qual a aranha que tece sua teia diante do escuro da noite (Pessanha, 2000). 
A interpretação do recalcado, assim, será uma interpretação que jamais encontrará seu término. As interpretações que revelam determinado pensamento inconsciente irão, no entanto, fazer a revelação simultânea desse escuro ou vazio do recalque originário, da face ausente do inconsciente, da sua abertura para a própria trama, que será tecida pela fixação da pulsão e pela ação do recalque. Elas irão, ao encontrar o sentido do discurso, dando a ele um novo esclarecimento e, assim, expandindo-o, também lhe revelar a presença da face ausente do inconsciente ou do seu ponto ausente. Mas a ação da interpretação não deverá, justamente, ser uma ação que sustente esse escuro de sentido, de representação e de pensar? Poderemos pensar na interpretação, desse modo, como um gesto em que se procura dar o prenúncio daquilo que parecia estar, até aquele momento, apenas retraído e indisponível para o pensar e, portanto, para a expansão ou ampliação da personalidade.

A interpretação, como esse gesto fecundo, parece procurar fazer nascer o impensável, brotar o jamais plantado e construir a morada do sem-terra no inabitável; nela, encontrar-se-á sempre a face escura do originário, que assinala, inevitavelmente, a presença da alteridade e do desconhecido heterogêneo ou, como nos diz Habermas (1998): “O reino do heterogêneo abre-se unicamente naqueles instantes de fascinante pavor em que as categorias, que garantem a interação íntima do sujeito consigo próprio e com o mundo, se desagregam.” (p. 202). Nesse sentido de heterogeneidade, há, assim, a presença marcante da homogeneidade, na forma do estranho pressentimento daquela natureza plural e condensada dos pensamentos oníricos inconscientes presentes simultaneamente, que precisam de organização do pensar e da linguagem para se apresentarem justamente como heterogeneidade.

$\mathrm{Na}$ interpretação, cujo sentido é fazer nascer essa alteridade heterogênea, há presente a disponibilidade do analista de que o analisando possa tornar-se algo para além daquilo que seria 
concebido como oriundo de um pensar psicanalítico ou de um pensar humanista. ${ }^{15}$ Há, na interpretação, um gesto em direção ao futuro, para além do possível: a fecundidade é aquilo que não só acolheu a possibilidade de germinar, mas que se abriu para testemunhar a alteridade/diferença que brota e que, estranhamente, não estava dada como possibilidade no instante da interpretação. Ela, portanto, parece criar a descontinuidade do mesmo, do homogêneo, pelo reconhecimento de que aquilo que faz brotar é também desigual, como dizemos do rosto de uma criança bem pequena que procuramos reconhecer: tem os olhos do pai, uma boca parecida com a da sua mãe, orelhas e queixo familiares, mas, estranhamente, uma face além do possível, desigual e autêntica. Como disse Levinas (1980/1988), “meu filho é um estranho [...]. É eu estranho a si." (p. 245); um autêntico cambiante, que pode ser reconhecido como uma incerteza quanto ao futuro. Nesse sentido, pensamos na interpretação como aquilo que, além de produzir o nascimento da alteridade, do filho estranho, mantém o futuro indeterminado e o expande. Expandir o desconhecido: tal é a tarefa da devoção; com ela, se sonham e se intuem imagens do futuro, formas possíveis de uma expansão que é, como porvir, na verdade, irrepresentável. No entanto, pela devoção, não só se dedica ao germe, como se recebe o fruto inusitado dessa cuidadosa devoção.

A interpretação, nesse sentido, não se dirige à descoberta do recalcado, mas à possibilidade de que aquilo que pode ser testemunhado, mesmo que ainda desconhecido por nós, possa se tornar, posteriormente, material de nossos sonhos que deverão ainda ser sonhados. A interpretação, que desvela aquilo que era impossível de ser apreendido, que surge nessa composição conjunta, nessa música dissonante que é o encontro analítico, e que pode tornar-se perturbadoramente harmoniosa, parece ser a possibilidade de que tal melodia, tal ritmo, seja sentido pela dupla e, com isso, que acabe por ser esquecido. Tal esquecimento é, também, o prenúncio de um sonhar.

\footnotetext{
${ }^{15}$ Entendemos que o pensamento psicanalítico pode se tornar, nesse sentido, um conjunto de técnicas e teorias que determinam seu objeto, fazendo com que o sujeito torne-se aquilo que ele mesmo pesquisa. Sobre o assunto do humanismo, recomendamos a leitura do trabalho de Heidegger (1949/1984), Sobre o humanismo.
} 
Ogden (2010) descreve de modo claro essa diferença entre interpretações:

A concepção de Bion (1962a) do trabalho do sonhar é o oposto do trabalho do sonho de Freud (1900). Este último refere-se ao conjunto de operações mentais que servem para disfarçar pensamentos oníricos inconscientes por meios como condensação e deslocamento. Assim, de forma derivativa/disfarçada, os pensamentos oníricos inconscientes são disponibilizados à consciência e ao pensamento do processo secundário. Em contraste, o trabalho do sonhar de Bion é aquele conjunto de operações mentais que permite que a experiência consciente vivida seja alterada de tal forma que se torne disponível para o inconsciente para elaboração psicológica (sonhar). (p. 129).

Há uma diferença significativa entre ambos: poderíamos dizer que Freud (1900/2006b) visava à interpretação de que derivados do inconsciente tornassem-se conscientes e, assim, iluminassem determinados pensamentos oníricos desconhecidos. Já Bion (1962/1994c) formulou a ideia de que haveria uma transformação da experiência vivida conscientemente para tornar-se inconsciente e que, assim, ela seria a fonte da geração dos sonhos. O primeiro pensou na transformação do inconsciente para a consciência; o segundo, inversamente, formulou a transformação da consciência para o inconsciente.

Em A interpretação dos sonhos (Freud, 1900/2006b), há a seguinte citação:

Um só pedal mil fios move,

Nas lançadeiras que vão e vêm,

Urdem-se os fios despercebidos

E a trama infinda vai indo além. (p. 309). ${ }^{16}$

Essa citação, que é usada por Freud (1900/2006b) para referir-se à "fábrica de pensamentos" de suas associações, nesse caso, com a palavra 'botânica', parte de seu processo

\footnotetext{
${ }^{16}$ O poema é uma citação de Fausto, de Goethe, cujos versos no original alemão são: "Ein Tritt tausend Fäden regt/ Die Schifflein herüber hinüber schiessen,/ Die Fäden ungesehen fliessen,/ Ein Schlag tausend Verbindungen schlägt."
} 
de autoanálise de seu Sonho da monografia de botânica, é, possivelmente, a expressão da sua apreensão desse emaranhado de pensamentos oníricos inconscientes formados a partir da experiência vivida. A trama infindável que vai indo além parece ser a própria constatação de que essa "fábrica de pensamentos" não cessa de se escrever e que pode, nesse trabalho de sonhar o vivido, fornecer aquilo que será posteriormente disponibilizado para o sonhar, não apenas na forma de imagens nas quais serão compostos e atribuídos sentidos, mas de experiências emocionais que poderão se tornar inconscientes.

Essa rendeira de Goethe parece tramar seus fios ao apertar um único pedal. Com um só pedal apertado, há a tessitura de mil fios, que se urdem na trama em que se compõe o tecido de nossos sonhos. Quantos mistérios não parecem residir nesse aperto do pedal! Ou nessa tecelã que, por sua ação, parece ser aquele que produz os sonhos que serão sonhados por nós (Grotstein, 2003). Com esse aperto do pedal, podemos perceber que aquilo que surge, mesmo que de modo derivado, talvez, como um vestígio, seja um coro palimpséstico, tal como expresso no verso de Hölderlin (1800/1991, p. 323): "Um coro somos nós. [Ein Chor nun sind wir.]." Um coro de mil fios urdidos e tramados uns nos outros, criados pelo tecelão que produz o sonho. São as tessituras que parecem recobrir, como um manto, o inominável território estrangeiro.

O estrangeiro, essa morada impossível, envia-nos derivados que são, tão somente, vestígios da multiplicidade, do infinito e da abrangência, da simetria e da atemporalidade; todos vestígios de um território inabitável, no qual não se erguem moradas e pelo qual seremos sempre e inevitavelmente saudosos, como aquele território que nos é tão profundo e íntimo, como um segredo guardado de nós mesmos, mas que, como Nietzsche (1873/1978b), poderíamos dizer que "atiramos fora a chave"; um profundo fundo sem fundo povoado, por fim, por nosso próprio parentesco com o outro: com o filho irreconhecível, com a alteridade do pai e 
com o reconhecimento de que o familiar pode ser a história de qualquer estranho; por fim, com a familiaridade com o estranho e com a própria humanidade que existe em nós.

Quando pensamos em interpretação com esse sentido de tradução e de, portanto, transformação dos vestígios desse território estrangeiro inabitável, parece que nos encaminhamos para compreender que precisamos inevitavelmente fazer do inabitável uma modificação significativa: construir e fundar habitação; espécies de falsificações da origem, que, ainda assim, possam expressar nesses vestígios a sua origem inominável. São falsificações para que não nos tornemos sem morada, tal qual uma multiplicidade sem unidade, uma simetria sem assimetria, uma ausência de tempo e de contradição ou, ainda, como um mergulho no infinito que não encontra limites no espaço sem fim. Tratamos, portanto, de encontrar abrigo e delimitação, mas nos deparamos com o estrangeiro, que, como abertura inominável e heterogênea, está sempre presente, mesmo na habitação mais protegida e prevenida contra sua presença desagregadora, mesmo se esse heterogêneo apresente-se inicialmente como homogeneidade... 


\section{O PALIMPSESTO E A TEIA DE ARANHA}

\subsection{Método Palimpséstico}

Pretendemos discutir sobre o método de pesquisa que desenvolveremos neste trabalho psicanalítico e, para isso, valemo-nos de uma pequena história, que tem a função de explicitar questões por meio de imagens. Ela será expandida posteriormente para uma dissertação cuja função será a de produzir o conhecimento que o método pretende investigar ("O" $\rightarrow$ "K") ${ }^{17}$. Usaremos um vértice ${ }^{18}$ literário que transformará aquilo que o originou, com a intenção de que não modifique mentirosamente os seus aspectos fundamentais, ou seja, buscaremos os invariantes (Bion, 1965/2004a) que poderão se conservar tanto de um ponto de vista literário quanto psicanalítico. As invariâncias de vértices distintos podem ser reconhecidas como possuidoras de qualidades que as aproximam daquilo que as originou e que pode ser reconhecido ou não, dependendo do observador. Ainda, distintos vértices procuram aquilo que permanece inalterado, apesar das transformações que se sucederam, partindo do pressuposto inicial de que há uma origem para a sucessão de transformações, a qual é designada por Bion (1965/2004a) de "O” e será usada aqui primeiramente do mesmo modo, pois procuraremos

\footnotetext{
${ }^{17}$ Utilizaremos, neste capítulo, algumas grafias encontradas no trabalho de Bion (1965/2004a), Transformações. A letra "O" será posteriormente discutida e será tema de desenvolvimento nas próximas páginas. A letra "K" refere-se a knowledge ou conhecimento. Bion (1965/2004a) utiliza essa letra quando se refere às transformações que ocorrem a partir de "O", ou da coisa em si, e que fazem com que os objetos (objetos psicanalíticos, por exemplo) possam se tornar objetos com os quais se estabelece um vínculo relacionado à nossa possibilidade de conhecer. Ou seja, determinado objeto passa a ter qualidades primárias e secundárias, que são aquelas qualidades a partir das quais conhecemos o objeto, mas por meio de nosso emprego dessas qualidades à coisa em si, que se mantém desconhecida. Nosso conhecimento é, portanto, fundamentado em nosso vínculo que altera a realidade de "O", tornando-a uma realidade cognoscível.

${ }^{18}$ A palavra 'vértice' foi usada com o propósito de utilizar a mesma terminologia usada por Bion (1965/2004a). Para esclarecer seu sentido, encontramos em Evidência (Bion, 1976/1985) uma passagem em que o autor faz uma descrição desse termo: "Picasso pinta um quadro em um vidro, de tal forma que ele pode ser visto de qualquer lado. Usando a minha mão, posso sugerir o seguinte: olhe-a de um lado; existe uma queixa psicossomática. Olhe-a do outro lado, agora é somapsicótica. É a mesma mão, mas aquilo que você vê depende do modo como observa; a partir de que posição, a partir de que vértice - use qualquer termo que gostar. Mas será que alguém olha para um caráter a partir de alguma direção? Novamente eu não sei como este problema pode ser resolvido, exceto pela prática da análise e exceto pelo analista em particular.” (p. 138-139).
} 
justamente apontar para sua natureza e manter viva a questão que não se interrompe com uma resposta.

Pretende-se, nessa discussão, mostrar que os vértices podem ser observados separadamente ou de modo conjunto. Quando observados de modo conjunto, o observador tem de se valer de uma possibilidade de observar tolerando paradoxos, por meio de uma visão que o inclua, designada como binocular (Bion, 1962/1991b). A visão binocular é a expressão de determinada possibilidade, mais frequentemente atribuída ao analista, de aguentar pacientemente a espera por um fato que poderá surgir destacando-se dos demais elementos em função dessa espera, como uma determinação relativamente sintética de um conjunto paradoxal e contraditório. Essa síntese, que se expressa por meio de um fato que aglutina e reorganiza a experiência, é um fato selecionado, não pela vontade do analista, mas pela revelação de uma coerência e organização de elementos anteriormente dispersos e não relacionados. $\mathrm{O}$ fato selecionado (Bion, 1962/1991b) é um elemento essencial no processo de descoberta do sentido, que pode ter elementos não relacionados, e a sua revelação constitui a passagem de uma posição caracterizada, na teoria das posições de objeto, como esquizoparanoide para uma posição de caráter depressivo.

As posições caracterizadas desse modo não são explicitações de posições relativas ao desenvolvimento mental, mas possibilidades de apreensão de uma realidade que está em processo de descoberta e em devir. As posições esquizoparanoide (Ep) e depressiva (D) são, assim, características de flutuações mentais, que ocorrem expressando desorganização e fragmentação, e aquisição de estabilidade e organização. Ep↔D são estados mentais que estão intimamente relacionados com a capacidade de tolerância de um novo pensar. Desse modo, para cada revelação sintética, podem surgir novos elementos que conduzam, mais uma vez, a mente a permanecer em uma posição de fragmentação (Ep), para uma eventual e futura depressão própria da posição D, quando organizará novamente os dados incoerentes. 
O fato selecionado compreendido dessa maneira não se confunde com uma ideia que pode ser superestimada pelo analista e que visa a tentar suprimir prematuramente a angústia proveniente de um estado de indefinição e fragmentação (Britton, 2003). Desse modo, antes de nos precipitarmos em uma direção que poderá nos dar uma falsa segurança em relação àquilo com o que estamos trabalhando, constituindo uma ideia superestimada acerca do método de trabalho usado, procuraremos dar continuidade ao processo de transformação (Bion, 1965/2004a), usando agora um vértice literário, criado por nós como uma transformação em forma de mito/sonho de sua origem (como nos revela, na grade de Bion (1965/2004a), ser característica de enunciados da coluna C), e dando mais elementos para uma posterior tentativa de elaborar aquilo que parece ser invariante entre os vértices. Podemos denominá-la fábula: a fábula do palimpsesto.

Um palimpsesto foi encontrado no Mar Vermelho. Tratava-se de um velho pergaminho, rasgado nas suas bordas, mas que conservou seu interior íntegro. Observaram tratar-se de um palimpsesto por ter colorações diferentes, de modo que uma mesma folha parecia conter bordas e um fundo de cor distinta da coloração do seu meio; quando colocado sob uma luz, desvelava letras de outras colorações, que haviam sido apagadas para que novas frases pudessem ser escritas. Sabiam os estudiosos que não havia nada de novo nisso: durante séculos, pelo alto preço dos pergaminhos, do papel, escritas eram raspadas até serem apagadas, para que outras frases pudessem ser escritas no mesmo lugar. No entanto, cada palimpsesto encontrado em jarros, como nesse caso, era celebrado como uma descoberta valiosa, não pelo fato de conter algo escrito que pudesse ser absolutamente novo, mas pelo fato de indicar, naquilo que havia sido suprimido, coisas que eram consideradas menos importantes, em face de outras coisas que precisavam ser escritas por cima.

Esse palimpsesto era praticamente igual a todos os outros que haviam sido encontrados naquele verão: escrito em grego do século II a.C., continha um registro administrativo de uma 
pequena comunidade que habitara aquela região antes da sua invasão e destruição pelos romanos, por volta do ano de 50 d.C., mas algo chamou a atenção dos historiadores que estudavam esse pergaminho. Quando colocado sob uma luz comum, ele parecia revelar ter sido raspado uma vez. Na verdade, essa impressão poderia se ter mesmo quando olhado a olho nu, pois algumas letras de outras cores apareciam ao observador, criando um grande contraste com as letras que estavam escritas por cima. Contudo, ao ser examinado por meio de raios ultravioletas, um método de estudo absolutamente novo e ainda muito controverso, aquele pergaminho começou a mostrar a sua verdadeira face: os estudiosos depararam-se com um indefinido número de camadas de raspagem e, com isso, uma multiplicidade de textos que haviam sido escritos e depois apagados em seu interior. Aqueles que testemunharam a descoberta ficaram absolutamente estarrecidos. Eles nunca haviam visto um palimpsesto com tantas camadas sobrepostas, com tantas camadas escritas e apagadas... Um rápido exame demonstrou que algumas das camadas certamente haviam sido escritas em outra língua, talvez aramaico ou talvez uma língua parecida com o aramaico, mas ainda não identificada.

Na perplexidade diante do pergaminho, cogitou-se, em determinado momento, que as camadas poderiam - inclusive - ter sido escritas por um mesmo punho, por uma mesma letra. Então, determinado especialista foi chamado; ele havia desenvolvido uma revolucionária técnica, que consistia em fazer um escâner de cada nível do pergaminho, por meio dos raios ultravioletas, de modo que fosse possível diferenciar os níveis apagados daqueles níveis posteriores, até o nível da escrita aparente. O procedimento foi realizado, mas durou semanas. Por fim, foi possível identificar sete camadas de escritos, com a possibilidade de serem ampliadas para cerca de doze. Com tantas camadas sobrepostas, alguém levantou a hipótese de se tratarem de paramnésias e que o principal do pergaminho deveria repousar em um texto original e fundamental. 
Com essa hipótese, o trabalho de decifrar e interpretar o pergaminho começou. Ao serem separadas as camadas, os pesquisadores perceberam que as mais profundas pareciam se constituir de poucas ou de pouquíssimas palavras. Linguistas foram chamados e formou-se um grupo coeso de trabalho dedicado noite e dia a desvelar todas as possibilidades contidas naquela folha de papel. Sabia-se muito pouco, no entanto, sobre esse palimpsesto, pois, em determinado momento, os pesquisadores, mergulhados na arte de desbravar os subterrâneos do papel, depararam-se com palavras de difícil tradução, espécies de balbucios linguísticos. Desejosos por encontrar a camada ainda mais profunda, quando avistavam apenas a ausência, usaram uma técnica pouco usual, mas a única capaz de revelar todas as camadas restantes do papel: o uso de bactérias acidófilas presentes no ácido tânico. A curiosidade sobre a primeira camada e a confirmação ou não da formulação de paramnésias fez com que a substância fosse usada duas vezes. Na primeira vez, o pergaminho - calado - nada revelou; na segunda, ante os olhares incrédulos e assustados dos pesquisadores, o palimpsesto dissolveu-se completamente.

Ao observar a sobreposição de camadas do palimpsesto, o procedimento de divisão das camadas para uma melhor discriminação de cada uma delas foi realizado com êxito até o seu limite. Foram traduzidas as camadas, uma por uma. As traduções revelaram-se excelentes, mas os tradutores acabaram seu trabalho receosos de que tivessem dado um sentido aos textos que fosse inevitavelmente interpretativo. Ainda, tal procedimento de análise impossibilitou que o palimpsesto fosse revelado como tal, ou seja, como sendo simultaneamente as diversas camadas de escritos. Ocorria que, quando liam determinado nível, o nível acima ou o nível abaixo se tornava esquecido. O mesmo pesquisador que havia proposto a hipótese das paramnésias, que incitou os outros pesquisadores a procurar um fundamento no qual encontraram o nada, formulou, muito a contragosto dos outros pesquisadores, a ideia de que, caso olhassem as camadas sobrepostas simultaneamente, seria possível fazer com que o material revelasse aquilo que havia nele e que ainda não estava revelado; ou seja, em sua totalidade, poderia haver certa 
repetição das palavras, certa semelhança da caligrafia, certa composição da escrita - que apenas uma visão em três dimensões poderia dar - e, principalmente, a seleção de um fato ou de uma ordem que poderia emergir do todo. O risco, todos sabiam, seria de que as inúmeras palavras sobrepostas misturassem-se e, assim, ficassem incompreensíveis.

Em um sábado pela manhã, em um clima de informalidade, com apenas a presença de alguns pesquisadores, o hipotético pesquisador fez o seu experimento - não mais com o próprio palimpsesto, que estava destruído, mas com suas imagens, que haviam sido registradas fotograficamente com o auxílio da tecnologia digital. Munido de todas as camadas do palimpsesto, primeiramente colocou todas elas sobrepostas. Olharam aquilo durante alguns minutos. O velho palimpsesto apenas tinha suas possibilidades limitadas pela confusão de palavras. Nada apareceu. No entanto, sem se dar por vencido, o pesquisador virou todo o conjunto, de modo que a visão dos pesquisadores passou a mirar horizontalmente a parte esquerda do palimpsesto, de forma que cada camada havia se tornado uma linha acima da outra. Nessa visão, os pesquisadores surpreenderam-se com o fato de que a primeira camada, superficial, era a linha maior e as outras camadas eram sucessivamente menores, de modo que o conjunto todo formava a imagem de um triângulo com a ponta para baixo.

Não satisfeito com tal visão, ele girou mais uma vez as camadas, que agora estavam sob a forma invertida do palimpsesto, com sua parte de trás como a parte da frente, e eram vistas novamente por meio de camadas sobrepostas, como palavras e letras coladas umas sobre as outras. Ele, então, distanciou as camadas uma das outras, de modo que cada uma delas mantivesse certa distância da seguinte. Pediu então para os presentes para que esquecessem por um instante as camadas e o conteúdo delas e olhassem atentamente para o conjunto todo. Sim, parecia indiscutível: tratava-se de uma teia de aranha, formada pelas palavras e pelos buracos entre elas. Por fim, o pesquisador ampliou a projeção de sua teia, tornando-a tão grande que fez 
com que cada pesquisador tornasse-se, diante dela, uma espécie de aranha, inscrita e pendurada em sua própria teia.

Deixemos agora esse momento de ficção, pois sabemos, para além dele, que Freud (1930/2006c) foi o primeiro a indicar que a mente humana poderia ser palimpséstica. Sua investigação, que designara como "atraente e importante", foi iniciada para tentar explicar como certos fatos emocionais poderiam permanecer na mente, ou seja, no momento em que algo se formou como registro mnêmico, esse registro não poderia perecer. Para explicitar sua tese, fez uma analogia com Roma, a Cidade Eterna; citamos:

Os historiadores nos dizem que a Roma mais antiga foi a Roma Quadrata, uma povoação sediada sobre o palatino. Seguiu-se a fase dos Septimontium, uma federação das povoações das diferentes colinas; depois veio a cidade limitada pelo muro de sérvio e, mais tarde ainda, após todas as transformações ocorridas durante os períodos da república e dos primeiros césares, a cidade que o imperador Aureliano cercou com suas muralhas. Não acompanharemos mais as modificações por que a cidade passou; perguntar-nos-emos, porém, o quanto um visitante, que imaginaremos munido do mais completo conhecimento histórico e topográfico, ainda pode encontrar, na Roma de hoje, de tudo o que restou dessas primeiras etapas. [...] Permitam-nos agora, num vôo da imaginação, supor que Roma não é uma habitação humana, mas uma entidade psíquica, com um passado semelhantemente longo e abundante - isto é, uma entidade onde nada do que outrora surgiu desapareceu e onde todas as fases anteriores de desenvolvimento continuam a existir, paralelamente à última. Isso significaria que, em Roma, os palácios dos césares e as Septizonium de Sétimo Severo ainda se ergueriam em sua antiga altura sobre o palatino e que o castelo de Santo Ângelo ainda apresentaria em suas ameias as belas estátuas que o adornavam até a época do cerco pelos godos, e assim por diante. (Freud, 1930/2006c, p. 15-17).

Trata-se de uma linda passagem. Freud (1930/2006c), embora tenha recusado permanecer com a atraente imagem de escavações para explicitar a existência de histórias antigas que não foram esquecidas pela mente, abriu para nós a possibilidade de compreender não apenas o palimpsesto, mas uma importante parte do trabalho do analista. Ou seja, como 
arqueólogo, o analista pode reconstruir aquilo que existe na mente de seu analisando, de modo a identificar situações emocionais que até então não tinham a possibilidade de serem formuladas. Por meio dessas construções (ou reconstruções), o antigo e o novo parecem poder coexistir simultaneamente e o analista parece não apenas poder identificar registros inconscientes de seu analisando, registros ainda vivos, mas dar a eles uma forma que parece ser a mais exata possível de uma história, de uma situação emocional e de situações que são indiferenciadas do ponto de vista temporal, ou seja, fazer uma (re)construção.

Mas assim como o arqueólogo ergue as paredes do prédio a partir dos alicerces que permaneceram de pé, determina o número e a posição das colunas pelas depressões no chão e reconstrói as decorações e as pinturas murais a partir dos restos encontrados nos escombros, assim também o analista procede quando extrai suas inferências a partir dos fragmentos de lembranças, das associações e do comportamento do sujeito da análise. Ambos possuem direito indiscutido a reconstruir por meio da suplementação e da combinação dos restos que sobreviveram. Ambos, ademais, estão sujeitos a muitas das mesmas dificuldades e fontes de erro. Um dos mais melindrosos problemas com que se defronta o arqueólogo é, notoriamente, a determinação da idade relativa de seus achados, e se um objeto faz seu aparecimento em determinado nível, freqüentemente resta decidir se ele pertence a esse nível ou se foi carregado para o mesmo devido a alguma perturbação subseqüente. É fácil imaginar as dúvidas correspondentes que surgem no caso das construções analíticas. (Freud, 1937/2006j, p. 277).

Vale lembrar que Freud (1930/2006c), nesse mesmo trabalho, diria que essa imagem pictórica de Roma conduz-nos a uma visão imaginária e absurda, isso porque a representação pictórica da história, contada de um ponto de vista espacial, só pode ser feita mediante a justaposição de figuras no espaço e o mesmo espaço não poderia ter dois ou mais conteúdos diferentes nele mesmo. Para responder a esse problema, pensamos que Bion (1965/2004a) ofereceu a imagem do palimpsesto, tal como estamos desenvolvendo neste trabalho, como aquilo em que é possível se inscreverem diversos conteúdos simultaneamente e que mais se 
aproxima da "visão" do psiquismo humano, repleto de camadas de pensamentos oníricos inconscientes.

Poderíamos continuar criando imagens com a intenção de explicitar pictoricamente um problema metodológico. Bion (1965/2004a) qualificou esse problema como um problema de vértices e deu a ele a possibilidade de ser compreendido segundo uma visão que compreendesse o vértice a partir de uma noção de origem, que é seu "fundamento" real e inacessível; ou seja, as reconstruções analíticas podem ser empreendidas, mas acaso não serão sempre reconstruídas com o material de que dispomos, que se encontra diante de nós?

Ao fundamento originário do vértice e das suas transformações, Bion (1965/2004a) dá a designação do símbolo “O”, com a intenção de não significá-lo com alguma palavra que já estivesse saturada de compreensões e designações. No entanto, paradoxalmente, indica que "O" aproxima-se da noção kantiana de nômeno e, também, das formas ideais do platonismo. Se o autor, por um lado, procurou deixar a noção de "O" insaturada, aplicando a ela uma letra que nada significaria, por outro, valeu-se de uma extensa tradição filosófica, iniciada em Platão, para caracterizar essa mesma noção - designada também como "divindade", "coisa em si" e "realidade última”. Pensamos que "O” deva continuar sendo designado como "O”, no sentido de podermos pensá-lo não exatamente como um "fundamento" que deve permanecer insaturado, mas como uma origem e, portanto, avesso a qualificações somente positivas.

Quando compreendemos que, metodologicamente, o fundamento pode permanecer como elemento invariante diante dos vértices que sofreram transformações, percebemos que a possibilidade de intuição desses invariantes passará a ser de especial relevância. Um dos problemas que surgem disso é o desenvolvimento por parte do analista de uma apreensão dos invariantes, apesar da massa infinita de dados sensoriais, que se apresenta, muitas vezes, contraditória e fragmentada. Por isso, é importante destacarmos a função da visão binocular, 
que é aquela visão que dispõe o analista para a tentativa de tolerância de dados contrários ou disparatados sendo fornecidos simultaneamente.

De modo geral - Bion (1965/2004a) critica -, criam-se teorias diferentes para cada dado contrário que se observa e isso se deve ao fato de que uma visão "monocular" tende a descrever determinado aspecto da realidade - como cada camada do palimpsesto - de modo a isolá-lo do restante do conjunto. Nesse procedimento "monocular", garante-se a coerência do dado observado, mas perde-se a visão contraditória do seu conjunto. A visão binocular, portanto, ocorre na tolerância de paradoxos. O que surge em decorrência disso é um fato selecionado (Bion, 1967/2000a; Britton, 2003), o qual emerge do conjunto contraditório como uma espécie de padrão ou configuração, que passa a dar coerência e significado a uma massa de fenômenos aparentemente não relacionados entre si. O seu surgimento na mente do analista deve-se, assim, mais à sua capacidade de espera, paciência, serenidade e tolerância do que a uma atividade por parte sua que teria como função a produção de conhecimento. O que fundamenta tal método é o reconhecimento da ignorância do analista sobre os motivos que levaram o paciente àquela sessão e, simultaneamente, a percepção da ignorância do paciente sobre esses mesmos motivos.

O fato selecionado é parte integrante do processo de transformação do Real em fato clínico psicanalítico e, assim, resguarda uma parcela de falsificação em relação à sua origem, ou seja, o fato selecionado que emerge do conjunto contraditório de experiências da sessão não é a expressão de uma verdade absoluta e guarda uma estreita relação com uma expressão inacabada da verdade; por isso, mantém aberto o horizonte do porvir. Entretanto, diante disso, percebe-se haver certa evolução na sessão; algo se coloca em curso, diante do qual apreendemos aspectos da verdade, oriundos das transformações ocorridas pela mente que apreende os fenômenos de uma realidade que permanece sendo incompreensível.

Um dos problemas levantados por meio do vértice literário é o da possibilidade ou não de atingir o fundamento das paramnésias, mas a teoria do recalque originário, como vimos, 
parece nos indicar que elas se tratam de inscrições sem um sentido fundamental e sem um conteúdo originário recalcado. Conteúdos recalcados, inscrições do palimpsesto, no entanto, parecem servir de exemplos, na psicanálise, dessa direção, ou seja, por meio da interpretação, aquilo que dá origem a determinado sintoma, sua determinação, pode ser apreendido e esse "fundamento" - inconsciente - daria, para tudo aquilo que surgisse posteriormente, para toda significação, para toda narrativa, para toda história e para todas as camadas do palimpsesto, uma nova compreensão, pois seria visto um novo sentido naquilo que já estava sendo observado. Teríamos, nesse caso, um conteúdo específico, como sendo uma determinação de eventos emocionais. Conhecer essa determinação seria saber sobre um conteúdo que é familiar, pois já esteve alguma vez acessível à mente consciente, e estranho, pois pertence a uma lógica distinta daquela da mente consciente e da possibilidade de legitimação por semelhança com outros conteúdos mentais conscientes.

A isso, designado por Freud (1919/20061) como Unheimliche, caberá, portanto, uma pergunta: será Unheimliche (o estranho familiar) o conteúdo inconsciente, o recalque ou a experiência da mente que observa conscientemente a heterogeneidade dos processos simétricos do inconsciente? Nessa experiência, não serão possíveis estranhos conteúdos múltiplos? Mas, se assim for, como podemos pensar a própria noção de “O”? Pois, nesse sentido, não estaremos, portanto, distinguindo conteúdos inconscientes, recalcados, da realidade última? Ou as escritas do palimpsesto de sua origem, do Real? Ou ainda: Unheimliche não designaria a experiência emocional da presença do desconhecido inominável e estranho naquilo que já havia sido reconhecido como um conteúdo recalcado, sua porosidade em relação ao Real? Assim, o estranho parece designar esse reconhecimento da desconhecida ausência de formas e palavras em algo que se parece realmente familiar; uma destituição da familiaridade na eclosão da alteridade, da passagem da alteridade no território familiar... 
Na demonstração do pesquisador de que haveria a possibilidade de apreensão do palimpsesto de um modo geométrico, ele indicou que o palimpsesto não precisaria ser compreendido apenas sob um vértice literário ou histórico, mas também por um vértice geométrico. Esse vértice geométrico, que mostrou uma representação triangular e, posteriormente, uma representação de teia de aranha como possibilidades do palimpsesto, conduziu o olhar dos pesquisadores para novas direções. A direção apontada pelo pesquisador foi a de insaturar a visão dos demais, proporcionando uma intuição sobre a natureza do próprio palimpsesto e da relação dos pesquisadores com ela. A organização dos dados imperceptíveis, insuspeitos, caracterizou-se como a formulação de um fato selecionado, o qual, ao invés de empregar uma hipótese definitória que poderia saturar novamente os elementos, deu a possibilidade para que cada pesquisador pudesse, por si mesmo, ser afetado pela possibilidade de crescer por meio da apreensão de determinada realidade, que implicou cada pesquisador como participante daquilo que observava, tal como foi revelado na imagem da teia gigante diante de cada um deles, inscrito e participando de suas linhas produzidas por palavras, frases e, também, por buracos escuros.

Os conteúdos presentes no palimpsesto não seriam - segundo essa metodologia - aquilo que parece ser o fundamental na sua apreensão. Sejam eles conteúdos desvelados ou incompreendidos, seriam, por sua vez, apenas transformações de uma origem, que, entretanto, não pode ser caracterizada somente como um elemento positivo, ou seja, como uma "causa primeira”. Nesse sentido, aquilo que se mostrou como o desejo de conhecer o fundamento, definido como "causa causadora", como a primeira escrita, pode ser melhor compreendido como o que move Édipo em sua trajetória sem fim rumo ao desvelamento de sua condição: o desejo pela verdade a qualquer preço (Bion, 1957/1994b).

Não precisamos dizer que, com isso, a realidade é tornada objeto e, como objeto, caracterizada como algo que está permanentemente acessível e disponível para a racionalidade. 
Nesse caso, a busca da verdade a qualquer preço apenas destruiu seu objeto, impossibilitando a observação de que havia o nada que nele se revelava. O nada, contrariando certo antigo provérbio latino que diz que dele nada vem - "ex nihil nihil fit" - precisaria ser reconsiderado como aquele aspecto do Real que se apresenta como uma visitação negativa, ou seja, que origina certa narrativa dos fatos clínicos psicanalíticos. O "fundamento", ainda, pode ser compreendido também como a tentativa de obtenção de uma resposta finalizante, uma tendência da racionalidade, que, ao buscar uma causa primeira, causadora das demais causas, originada por um princípio da razão, tal como o princípio da razão suficiente, possa dar fim à curiosidade e tapar buracos inevitavelmente mantidos como buracos abertos. Bion (1960/1992) fala-nos desse problema dessa maneira:

Sempre há um impulso a se pespegar uma resposta, de tal forma que impeça que qualquer fluxo se espalhe pelo espaço existente. A experiência familiar é a de que você pode dar aquilo que chamamos de 'respostas'. Mas estas são, na realidade, tapa-buracos. É um modo de pôr fim à curiosidade - especialmente se você consegue ter sucesso em acreditar que uma resposta é a resposta. De outra forma, você vai alargar a brecha, este desagradável buraco onde uma pessoa não tem nenhum conhecimento. [...] Mesmo no domínio da curiosidade mental, de querer saber algo a respeito do universo no qual vivemos, este buraco pode ser bloqueado por respostas prematuras e precoces. (p. 34).

O palimpsesto, revelado como uma massa de camadas de escrita sobrepostas, apenas poderia ser compreendido quando essa massa pudesse ser ordenada segundo uma posição geométrica, que revelasse o palimpsesto como uma teia diante da qual os pesquisadores estão inscritos e que simultaneamente se revelasse com os seus buracos vazados, os quais são aqueles que podem ser bloqueados por "respostas prematuras e precoces".

A relação que podemos estabelecer entre "O" e esses buracos vazados é o motivo de nossa pesquisa. Incomodamo-nos com o fato de que não parece ser possível existir uma natureza simultaneamente desprovida de saturação e positiva, no sentido de que nela seja 
desenvolvida uma qualidade na forma de uma predicação ou de uma entificação, mas, também, não parece sensato atribuir a uma natureza negativa algo que poderá manifestar-se apenas como positividade, nas suas transformações em representações de distintos vértices. Assim, o Real (ou “O”) parece conglomerar esse profundo problema.

Acompanhamos o pensamento bioniano de que "O” não é possível como conhecimento, pois o conhecimento já denotaria um vínculo que é uma transformação da realidade última; no entanto, "O" pode ser apreendido quando se encarna na personalidade. Parece-nos que está inscrito nesse ponto uma das mais enigmáticas questões da psicanálise: como poderemos favorecer a encarnação da realidade do paciente nele mesmo? Para explicar essa ocorrência, valemo-nos de duas ideias. A primeira é a da importância de se transpor o hiato do conhecimento de um fenômeno mental, para poder ir sendo aquilo que se é - ir sendo-se real -, mas a primeira dificuldade da transposição desse hiato decorre da resistência. Vamos nos deter um pouco sobre esse ponto: uma das expressões da resistência é a mentira.

O próprio conhecimento pode ser uma adesão a formulações "mentirosas", pertencentes à coluna 2 da grade de Bion (1965/2004a), derivadas da ação de uma interpretação que pretende romper esse hiato, uma barreira a ela. Um fato superestimado pode também ter essa função; poderíamos dizer que qualquer compreensão do palimpsesto, quando visto sob a forma de camadas sobrepostas, em que se revele uma delas e se ocultem outras, é uma superestimada quando trata de uma interpretação sobre o palimpsesto, por isso é falsa. Nesse sentido, a falsidade, longe de ter uma conotação negativa ou desvalorizada, é compreendida como parte inerente do processo de conhecimento da realidade. No entanto, deve ser distinguida de outro processo - mais complexo -, que não se fundamenta na compreensibilidade, mas na possibilidade de tornar-se a realidade que poderia ser conhecida.

A ação de uma interpretação deve, portanto, gerar um efeito maior do que aumentar ou agregar conhecimento sobre o paciente; ela deve proporcionar uma experiência do paciente 
consigo mesmo, com sua própria realidade. Uma experiência emocional que gere crescimento não pode ser obtida, segundo esse ponto de vista, por um conhecimento sobre um conteúdo mental ou sobre um saber sobre uma camada do palimpsesto, como se fosse um saber totalizante. Uma interpretação - e Bion (1965/2004a) chama-nos a atenção para esse fato - deve proporcionar um caminho para que o Real possa ser encarnado e, assim, tornar o paciente apto para ser aquilo que nele há para ser, que urge para ser. No entanto, a emergência de "O" é sentida não como algo positivo ou proveitoso, mas, de modo geral, como uma catástrofe no aparelho mental, que é um aparelho para dar conta dos pensamentos; um aparelho que se orienta segundo organizações lógicas. A catástrofe ocorre diante dessa ação contrária ao modo de organizar os dados sensoriais do aparelho mental e a resistência opera contra essa catástrofe.

A segunda ideia decorre da importância de criar condições maturacionais para que possa ocorrer essa encarnação da realidade no paciente, pois deve ser a realidade a consentir encarnarse na pessoa do analisando e não o contrário (Bion, 1965/2004a), ou seja, a direção da interpretação é favorecer a maturação da personalidade, para que ela possa abrigar a emergência de sua própria realidade, que irá se encarnar, tornando-a real. A maturação da personalidade é a possibilidade de sua própria expansão.

Bion (1960/1992), em um de seus pensamentos passados para o papel, que posteriormente foram designados como Cogitações, descreve-nos o palimpsesto como representando camadas de conduta de um comportamento de um paciente, ou seja, o comportamento humano poderia ser compreendido não sob um fundamento inconsciente que o originou, mas segundo diversos pontos de vista. Determinado comportamento pode ser compreendido como um palimpsesto e, nele, serem detectadas camadas de "escritos" - camadas de pensamentos oníricos inconscientes. Assim, todo conhecimento desse comportamento será um conhecimento que se baseará em uma visão monocular, quando proporcionar uma visão sobre a realidade de uma camada de conduta baseada em determinado "conteúdo" emocional. 
Ainda, as camadas podem ser interpretadas como realidade psíquica; caso as compreendamos assim, elas serão as expressões de determinado conteúdo emocional. No entanto, vista em seu conjunto, a realidade psíquica não é apenas esse conteúdo e não é também outro conteúdo, mas o conjunto "palimpséstico". Esse palimpsesto revela-se como possuidor de camadas sobrepostas inarticuladas e contraditórias de pensamentos oníricos inconscientes com possíveis vínculos entre si ("L", "H", "K") ${ }^{19}$ e cesura entre as camadas; além disso, há a presença do Real envolvendo as camadas, como seu elemento vazado.

Pensamos que nosso método de trabalho psicanalítico pode ser compreendido como a tentativa de produzir o desenvolvimento ou a maturação da personalidade para que ela possa, por meio desse desenvolvimento, tornar-se real; tal método presume, no entanto, uma compreensão de que o amadurecimento pressupõe um desenvolvimento da negatividade, ou melhor, daqueles aspectos do Real que parecem ser esquecidos na tarefa psicanalítica de tradução interpretativa, na qual se encontram numerosos sentidos inconscientes, que podem ser apenas o esquecimento das visitações desse Real. O amadurecimento parece ter uma relação com a expansão mental, se pensarmos que a expansão, nesse caso, não significa apenas a produção incessante de sentido, mas a ruptura com o sentido e a imaginação para a apreensão daquela visitação negativa do Real.

A realidade do paciente é, simultaneamente, cada camada do palimpsesto, seus conflitos e contradições, os vínculos e a cesura presente entre elas. Já a cesura pode ser compreendida como esse elemento vazado, esse transiente entre os conteúdos distintos, e simultaneamente o link, a sinapse que é estabelecida nesse elemento vazado, como um transiente que liga e articula elementos paradoxais e contrários. Usamos, aqui, o termo 'cesura' do mesmo modo que foi usado por Bion (1963/1997); aliás, a cesura parece ser uma ideia fundamental para que possamos compreender a dimensão que abrange o palimpsesto.

\footnotetext{
${ }^{19}$ Trata-se das iniciais para Love, Hate e Knowledge; tipos fundamentais de vínculos relativos às transformações de “O” (Bion, 1965/2004a). Os vínculos, nesse sentido, não são os traços originais da realidade, mas as transformações de uma origem desconhecida.
} 
Essa palavra, usada primeiramente por Freud (1926/2006m), em Inibições, sintoma e ansiedade, apareceu para descrever um estado de descontinuidade, de mudança de um estado a outro, que, no entanto, pode não revelar justamente como, a partir dele, ocorreu certa continuidade. Trata-se da seguinte passagem:

Há muito mais continuidade entre a vida intra-uterina e a primeira infância do que a impressionante censura [cesura $]^{20}$ do ato do nascimento nos teria feito acreditar. O que acontece é que a situação biológica da criança como feto é substituída para ela por uma relação de objeto psíquica quanto a sua mãe. (p. 137).

Bion (1963/1997), por sua vez, ampliando essa noção, descreve-nos, em seu trabalho Cesura, a necessidade de interpretar justamente a cesura, ou seja, o vínculo, a sinapse ou a própria descontinuidade que gera continuidade. Há, para ele, certas interrupções ou intervalos nas sessões de psicanálise que poderiam ser observáveis como indícios de que os analisandos poderiam demonstrar certa passagem de um estado mental para outro, como forma ou expressão de uma descontinuidade interna, que não seria produzida por algum agente externo. Tálamo (1997) descreve esse processo como o de tecelagem:

Alguns dos exemplos usados por Bion, de eventos que tem afinidades com cesuras (vínculos, sinapses) são internos, parte do trabalho de 'tecelagem' que a pessoa faz de suas experiências (como um nó, em uma seda de shantung) e precisam ser compreendidos de um modo diverso daquele que se encara como imposições externas naquilo que era, anteriormente a cesura, um fluxo normal. (p. 380).

Essa tecelagem pode, assim, ser compreendida como uma atividade de produzir algo por sobre as rachaduras, fraturas, buracos e descontinuidades. Interpretar a cesura é simultaneamente identificar esses buracos e tecer neles os fios que ligam um estado mental ou

\footnotetext{
${ }^{20}$ A palavra alemã é Caesur, mas, na edição alemã de 1926, ela saiu equivocadamente impressa como Censur, ou censura. A edição brasileira acompanhou essa tradução.
} 
um pensamento onírico inconsciente a outro. A cesura, que também é parte das costuras ou ligações que são feitas de sua própria tessitura, refere-se principalmente aos "buracos da teia" e, do ponto de vista do palimpsesto, às descontinuidades entre as camadas de inscrições e de registros, mesmo aquelas que, como o porto sepulto (Ungaretti, 1914-1919/2003), parecem estar apagadas.

O elemento vazado remete-nos ao problema do fundamento - ou, ainda, ao problema do fundamento sem fundamento. Valemo-nos de uma nova imagem para representar esse problema, uma imagem que encontra profundo eco em nosso trabalho como um todo:

Enquanto a aranha cerzia o frágil arabesco de sua teia, vi que a imensidão da noite circundante permanecia atravessando todas as linha brancas do traçado e que ela passeava dentro da doçura de um abismo. Lembrei-me então de uma outra maravilha cujo nome é homem e descobri o segredo de uma afinidade! Se a aranha faz a teia, o homem tece biografia. Biografia é a tristeza de não ter podido residir no elemento negativo: se o homem foi constrangido a abandonar a 'simplicidade da noite' pela loucura do nascimento, ele pode, numa rememoração permanente do oculto, suportar a luz cansada que vigora na passagem pelo exílio deste mundo. (Pessanha, 2000, p. 57).

Essa passagem revela, com profundo tom poético, o fundo sob o qual aparece o palimpsesto e suas camadas. Fundo colossal, mas simultaneamente fundo nenhum, ele é o desabrigo do fora da teia, ou seja, aquele nada (Real) a partir do qual o homem escreve "palimpsesticamente" a tessitura de sua biografia. Para intuir o desconhecido, é preciso suportar o desabrigo da ausência de verdades absolutas e, ao suportar esse desabrigo - como condição fundamental de nossa existência -, enquanto somos por ele convocados a mergulhar e a permanecer, somente desse lugar avistamos aquelas terras desconhecidas e exuberantes que um verdadeiro exilado pode observar. Permanecer em sintonia com "O" é permanecer nesse desabrigo. 
O trabalho do analista, com sua capacidade de tolerar o desabrigo e as oposições das camadas, apenas tem a função de ajudar o paciente a não se fixar em uma compreensão sobre si mesmo que impossibilite uma apreensão mais ampla de sua realidade mental. Assim, ao longo deste trabalho, dedicaremo-nos à exploração dessa problemática, ou seja, de como podemos ajudar a fazer com que determinada realidade possa ser encarnada no paciente, por conta de sua visitação nas sessões de psicanálise. Exploraremos isso tendo como pano de fundo a imagem do palimpsesto, com suas diversas camadas e também como possuidor de aberturas vazadas e sem fundamento originário.

Essa compreensão do trabalho psicanalítico, como a ampliação da capacidade de apreensão da realidade psíquica, somente é concretizada pelo processo maturacional do paciente, o qual não pode ser identificado como um processo por meio do qual se criará desenvolvimento, mas como um processo em que se desenvolverá a possibilidade do paciente de se manter em desabrigo. Nesse sentido, a apreensão sobre si mesmo é o prenúncio da possibilidade de tornar-se aquilo que se apreende, quando o que se apreende é ser a realidade da tessitura da teia do palimpsesto e o elemento vazado que sustenta essa teia no escuro vazio da noite. Não será o analista que definirá aquilo que poderá surgir como a realidade do paciente; tornar-se aquilo que se é não pode ser conhecido e também não pode ser produzido. Pensamos, assim, um modo de criar condições para que aquilo que exista de Real possa existir na personalidade do paciente. Os conteúdos mentais da sua realidade psíquica subjetiva tornam-se, desse modo, elementos derivados do fundamento Real presente na condição da existência do homem.

Poderíamos também afirmar, de outro ponto de vista, que o palimpsesto é uma polifonia, a qual é, em última instância, Sobórnost! Safra (2004) apresenta-nos, em seu trabalho A po-ética na clínica contemporânea, a noção de Sobórnost, termo que prefere deixar no original russo pela dificuldade de sua tradução. Ele descreve Sobórnost (unidade, conciliar, comunitário) 
como uma "pan-unidade", ou seja, como a singularização da vida de muitos outros em cada um de nós. $\mathrm{O}$ autor apresenta-nos essa ideia, que parece ser tão familiar à ideia de palimpsesto presente neste trabalho, para dizer que a vida pessoal humana está marcada pela vida dos ancestrais e pelo pressentimento daqueles que ainda virão. Assim, Sobórnost refere-se a uma multiplicidade de outros presentes em nossa própria natureza, sendo uma referência à nossa paradoxal condição de ser único e múltiplo, identidade e alteridade, em última instância, coletividade.

\subsection{Um Centro Fugidio}

Falaremos sobre a importância de proporcionar maturação ao paciente para a apreensão de sua realidade mental. Havíamos discutido isso do ponto de vista da interpretação: uma ação que promove maturação, mas a maturação pode apenas ocorrer sob condições espontâneas, ou seja, a psicanálise não pode produzir maturação, pode somente oferecer condições para que aconteça e a interpretação é o oferecimento dessas condições. Podemos dar as condições para que, por exemplo, um vinho amadureça, mas não podemos saber, de antemão, se ele irá amadurecer adequadamente ou não, ou seja, não podemos afirmar que o paciente irá amadurecer dando a ele certos estímulos experienciais, pois a experiência que o paciente terá consigo mesmo diante desse estímulo interpretativo permanecerá como algo que somente poderá ser parcialmente percebido pelo analista mediante a reação do paciente em face da interpretação, isto é, de uma nova fala, de uma nova associação.

Não sabemos dizer de antemão quais experiências proporcionarão seu amadurecimento, mas uma das condições para o processo maturacional é o desenvolvimento de condições imaginativas. Não nos referimos, certamente, àquela imaginação que tem como função a alienação das condições reais dolorosas e angustiantes da vida mental, mas a imaginação que 
fornece a possibilidade de contato com aquilo que pertence a uma dimensão que nos é inevitavelmente deslocada, por ser algo que não temos acesso, a não ser indiretamente. Diremos, desde já, tratar-se de um centro fugidio. A imaginação, nesse sentido, é a possibilidade de aceitar a presença de uma realidade de que não temos conhecimento, mas para a qual olhamos e, por não podermos ver, imaginamos sua presença e realidade; ainda, é a própria condição humana quando em face da impossibilidade de acesso direto ao Real.

Podemos ter clareza dessa condição especialmente no conflito edípico, quando a criança sente estar deslocada da cena de amor dos pais e a imagina ocorrendo longe dele, em outro lugar, no quarto ao lado (Britton, 2003). Esse deslocamento possibilita o desenvolvimento da imaginação como um modo de lidar com angústias profundas e dolorosas relacionadas com o abandono e a solidão. A imaginação cria uma cena existente e real, acrescentando a ela um espectador, que sonha com ela. Assim, a cena não pertence mais a uma ordem de uma relação entre duas pessoas, mas a uma nova ordem, com um terceiro que a olha e a cria e que participa dessa cena imaginariamente, principalmente por não estar nela. Participando dessa cena como um espectador distante, ele imagina aquilo que faz com que mais intensamente participe dessa realidade, ou seja, ele sonha com ela. Esse sonho é, na verdade, a própria tessitura da teia que nos segura no escuro da noite, para que não caiamos no fundo do vazio sem nome do Real. Em outras palavras, aquele trabalho de tecelagem descrito por Tálamo (1997).

Sempre que permanecemos em vértices fixos, em camadas do palimpsesto absolutas e rígidas, impossibilitamos que nosso olhar volte-se para essa condição deslocada que a realidade mental vislumbra, ou seja, nossa condição de mobilidade mental decorre da possibilidade de nos deslocarmos de uma camada a outra, quando podemos imaginar aquilo que nossos olhos não veem. Esse deslocamento ou mobilidade provém da capacidade de elaboração de angústias relacionadas ao abandono e à solidão ou de sentimentos de não ter posse de nenhuma verdade realmente perene e absoluta, e apenas pode ocorrer quando esses sentimentos convertem-se em 
imaginação sobre aquilo que ocorre "ao lado", que não é inteiramente apreensível e que não estamos de posse ou domínio. Sabemos, no entanto, que essas possibilidades imaginárias apenas nos fornecem aquilo para o que somos impingidos a olhar: uma cena fugidia e imaginada. Contudo, essa cena imaginada é o produto de uma imaginação que não pôde ver aquilo que estava fundamentalmente embaixo de seu nariz: o vazio escuro e negativo da teia.

\subsection{Questões sobre a Ignorância}

O medo da ignorância pode produzir as condições para a criação de ideias superestimadas e idealizadas (Caper, 2002). Entretanto, gostaríamos de poder nos manter pacientes até que surja um fato selecionado (Bion, 1962/1991b), ou melhor: manter-nos em suspensão, no próprio indeterminado, na espera não por algo específico, mas dispostos e abertos ao próprio escuro, ao mistério e ao velamento.

Mas é bom saber que nossa inquietação pode ser sintetizada por meio de duas perguntas: $\left(1^{a}\right)$ seriam nossas teorias e a nossa prática psicanalítica apenas paramnésias que têm a função de criar possibilidades imaginárias diante de nossa ignorância e angústia em relação ao Real? e $\left(2^{a}\right)$ seriam essas possibilidades imaginárias apenas imaginação, ou seja, modos não de acesso ao Real, mas modos que nos permitem vislumbrar sempre - e apenas - camadas e mais camadas de possibilidades interpretativas? Bion (1976/1985), em Evidência, faz a primeira dessas perguntas da seguinte forma:

É bom ter em mente a possibilidade de que, como psicanalistas, estamos lidando com uma coisa muito extraordinária - uma personalidade ou um caráter. Você não pode tocá-la ou cheirá-la, ou senti-la, e se você acabar se sentindo cansado, e mais ignorante do que de costume, é útil apelar para a paramnésia mais próxima, que seja portátil, a teoria psicanalítica mais próxima sobre a qual você se encontra mentindo. Não seria terrível se o todo da psicanálise se tornasse uma vasta 
elaboração de paramnésias, algo com que se intenta preencher o vazio - o vazio de nossa aterradora ignorância? (p. 137).

Portanto, a abertura ao porvir, na indeterminação, na espera silenciosa e paciente que se aproxima de um estado de serenidade, é também poder pressentir o próprio vazio de nossa ignorância, de uma ignorância que parece ser, por vezes, impossível de se sustentar, de se conter. Não podemos esquecer que a pedra angular da filosofia ocidental foi baseada naquelas interrogações que procuravam sistematicamente atordoar o interlocutor com um movimento de aporia, em que não se chegava a lugar algum, a não ser esse: a constatação da mais profunda ignorância sobre todas as coisas.

\subsection{Os Fatos Clínicos Psicanalíticos e o Real}

A psicanálise foi definida inúmeras vezes por Freud. Uma de suas definições comumente aceitas é aquela expressa nos seus dois verbetes de enciclopédia, que foi produzida quando indagado pela Enciclopédia britânica a responder ao que era a psicanálise. Nessa ocasião, ele formulou que a psicanálise era o nome de: $\left(1^{\circ}\right)$ um procedimento para a investigação de processos mentais que, de outra forma, são praticamente inacessíveis; $\left(2^{\circ}\right)$ um método, baseado nessa investigação, para o tratamento de distúrbios neuróticos; e $\left(3^{\circ}\right)$ uma série de concepções psicológicas adquiridas por esse meio e que se somam umas às outras para formar progressivamente uma nova disciplina científica (Freud, 1926/2006n).

Por fatos clínicos psicanalíticos designamos aqueles que ocorrem quando está acontecendo uma sessão de psicanálise; o problema está em explicitar quais são esses fatos e quando está ocorrendo uma sessão de psicanálise. Trata-se de um assunto polêmico, visto que poderíamos, com isso, designar psicanálise como algo que não pode ser qualificado como tal. Portanto, procuraremos primeiramente qualificar uma sessão como psicanalítica, de modo que 
os qualificativos encontrados sirvam para discriminar a sua ocorrência. Em seguida, procuraremos dizer que os fatos que ocorrem em uma situação em que existem tais qualidades serão fatos clínicos psicanalíticos; valemo-nos, assim, das considerações de Caper (2002), que descreve pormenorizadamente sua concepção sobre fatos clínicos psicanalíticos, e de Bion (1963/2004b), que caracteriza a ocorrência da psicanálise. Nosso problema será o de saber se os fatos clínicos psicanalíticos são somente construções imaginárias ou se são a expressão simultânea de uma visitação do Real; ou, dito de modo mais completo, nosso problema será o de saber a relação dos fatos clínicos psicanalíticos com o esquecimento e a visitação do Real.

Um fato clínico não pode ser algo que esteja para além do campo da experiência; isso é importante porque não podemos entender como fato clínico algo que não seja apreensível, visto que um fato não é algo destituído de seu caráter fenomênico. Tendo um caráter fenomênico, precisamos compreender que haverá uma mente que o formula, conforme as suas qualidades. Esse pensamento é originário de Kant (1787/1994), que no século XVIII formulou que a realidade fenomênica seria conhecida apenas através das categorias mentais que a apreendem. Assim, um fato não pode ser independente do método empregado para observá-lo e também não pode ser distinto da teoria que o fundamenta; um fato clínico também está vinculado de modo dependente com a linguagem.

Essas considerações de Kuhn (citado por O’Shaughnessy, 1994) servem-nos de diretrizes, pois nos fazem entender que os fatos clínicos psicanalíticos são fatos e não o próprio inconsciente ou a verdade. O fato clínico pode ser descrito, compreendido e tematizado; podemos levar tais fatos para a supervisão ou discuti-los com colegas. Os fatos clínicos psicanalíticos são fatos que ocorrem ou ocorreram na sessão e que se baseiam na possibilidade de serem observados como fatos, ou seja, como situações incognoscíveis transformadas em fenômenos por nossa capacidade compreensiva, de exame e de formulação de narrativas. 
O fato clínico psicanalítico ocorre por meio de um método de observação, o qual possui uma teoria. Para nós, essa teoria é uma metapsicologia. Há uma complexa relação entre a teoria e o fato clínico, mas o que pretendemos é explicitar que os fatos apenas são fatos quando há um observador que os apreende, que não é isento, neutro, mas observa por meio de um lugar que ocupa na situação psicanalítica, e esse lugar é tanto o lugar transferencial quanto o lugar de análise, que deve ser um descolamento daquele. Seja como for, concordamos com O’Shaughnessy (1994) quando afirma que os fatos clínicos não são fatos puros. Eles não são fatos puros por não serem apreendidos sem um observador e não são fatos puros por não possuírem uma classificação de modo a serem exatamente distintos de outros fatos, ou seja, os fatos clínicos são aqueles que ocorrem em uma sessão de psicanálise, mas esses fatos, como a "memória do analista", a "memória do paciente", a descrição de um "som vindo de fora da sala", as "relações pessoais" descritas pelo paciente, as "experiências emocionais na sessão", as “associações do paciente” e a "interpretação do analista”, não podem ser etiquetados e rotulados como pontuais, estanques. Eles são, de modo geral, um amálgama de alguns fatos relacionados entre si. Assim, uma "experiência emocional na sessão" pode estar ocorrendo junto a um "som vindo de fora da sala" e ser proporcionada por uma "interpretação do analista", que amadureceu a relação da experiência com o som acontecer com certo sentido, desencadeando uma "memória do paciente".

O fato clínico, nesse caso, será um fato em que uma série de estímulos estará acontecendo simultaneamente e a sua designação, por parte do analista, geralmente será uma interpretação cujo objetivo é formar uma sintética composição dessa série de estímulos. Ocorre que esse fato clínico psicanalítico, como um fato sintético proveniente de uma ação interpretativa, é o fato a partir do qual a descrição de toda a cena será contada posteriormente, na descrição do fato para publicação, numa narrativa que compreenderá certo exame. Como exemplo clássico, podemos dizer que, em O homem dos ratos, Freud (1909/2006o) apreendeu o 
fato clínico de seu paciente como um fato conflitivo que emergiu durante as sessões na relação transferencial: o fato do recalque do sentimento de ódio dirigido a uma figura amada - seu pai.

Esse fato clínico psicanalítico, como decorrente de uma ação interpretativa, poderia ser explicitado como a manifestação de determinada realidade psíquica do analisando. Poderíamos, portanto, afirmar que os fatos clínicos psicanalíticos são os fatos de determinada realidade, da realidade da vida mental desse analisando. No entanto, sabemos que esse fato clínico não ocorre fora do campo em que ocorre a psicanálise e que a psicanálise é uma atividade intersubjetiva, produzida artificialmente. Assim, parece-nos relevante destacar algumas evidências da ocorrência da psicanálise, conforme assinalado por Winnicott (1963/1982b), Caper (2002) e Bion (1963/2004b).

1. Isolamento dentro de uma situação de intimidade. A psicanálise é o próprio aparelho que produz os seus fatos, os quais são formados, primeiramente, pela possibilidade do analista de manter uma atmosfera de privação de seus próprios desejos e de saber que a intimidade apenas poderá advir quando respeitado o fato de que cada pessoa é basicamente isolada da outra e incomunicável naquilo que produz sua comunicação (Winnicott, 1963/1982b). Bion (1963/2004b), assim como Winnicott (1963/1982b), elaborou importantes contribuições sobre a importância do sentimento de isolamento permanente no indivíduo e de que as experiências mais importantes ocorrem em uma atmosfera de solidão. A intimidade psicanalítica será, desse modo, aquela intimidade que promoverá que o isolamento permanente do indivíduo mantenhase, seja respeitado como tal e produza experiência intangível e incomunicável, bem como uma possibilidade de comunicação. O analista, por sua vez, não poderá privar o paciente do sentimento de isolamento, que faz com que não seja possível compartilhar com ninguém aquilo que ocorre nessa situação. Trata-se, portanto, de algo paradoxal: que uma situação de intimidade garanta o isolamento permanente do indivíduo e a sua incomunicação, como aquela quietude e silêncio em si mesmo, e que esta possa ocorrer na presença de alguém. Certamente, trata-se de 
uma presença possibilitadora do isolamento e não de uma presença intrusiva, que dará ao paciente a possibilidade de saber que o isolamento permanente de si mesmo ocorre na impossibilidade permanente e fundadora de comunicação com o mundo da alteridade, não eu.

Essa situação, que evidencia o acontecimento psicanalítico, revela que a psicanálise compreende, fundamentalmente, o homem como possuidor de uma solidão, isolamento e incomunicação originários, como condições fundadoras, e que o homem desenvolve a possibilidade de toda e qualquer comunicação a partir dessa condição. No entanto, trata-se de uma condição que não deverá ser suplantada: a própria atividade psicanalítica deve criar condições para que essa situação possa se estabelecer nas sessões, ou seja, o analista não pode privar o paciente de sua própria condição. Para isso, ele deverá estar situado nessa condição, ou seja, na condição de possibilitador do isolamento que desvela a condição de solidão, incomunicação e isolamento originários do paciente. O analista, portanto, precisa estar situado nessa mesma condição.

2. Apreensão da realidade psíquica. As sessões de psicanálise visam à apreensão da realidade psíquica. Os fatos clínicos, em uma sessão de psicanálise, são elementos destacados da realidade psíquica do paciente e podem ser representados de modos variados, mas serão sempre representações de estados mentais mais amplos, da própria realidade psíquica do paciente, que é, por si só, inabarcável em sua totalidade. A realidade psíquica, nesse sentido, é o próprio inconsciente; Freud (1900/2006b), intuindo o próprio inconsciente, destacou elementos dele, que denominou fantasias. Por isso, a psicanálise procura aquilo que é a realidade psíquica, sabendo que essa realidade não será compreendida pelo paciente. Assim, uma interpretação destacará um elemento da realidade psíquica do paciente, mas a função dessa interpretação não será fazer com que o paciente mude seu comportamento após saber sobre esse elemento. O paciente poderá usar a interpretação do analista para amadurecer sua capacidade de apreender sua realidade psíquica, por meio dos elementos destacados pelo analista. O processo analítico, 
portanto, tem a função de produzir maturação no paciente, para que ele possa expandir sua capacidade de apreensão de sua própria realidade psíquica. $\mathrm{O}$ analista, por sua vez, situa-se de modo a saber diferenciar aquilo que é um elemento da realidade psíquica e aquilo que é a própria realidade, embora incognoscível, intuindo-a e mantendo-a em seu foco.

A interpretação, que visa à possibilidade da apreensão da realidade psíquica, tem a função de produzir a maturação para a expansão dessa personalidade, mas parece, nesse sentido, ser o prenúncio de outro processo, que discutiremos posteriormente: a ruptura, na forma da mudança catastrófica. Expansão e ruptura parecem ser, assim, processos que se encontram no interior do processo analítico; a primeira em decorrência da maturação e ampliação da apreensão da realidade psíquica e a segunda em decorrência da apreensão do Real.

Algumas questões relativas ao método psicanalítico surgem nesse momento. Propomos ao paciente a experiência da livre associação; nessa experiência, em que o paciente pode, de um modo aparentemente livre, falar sobre aquilo que lhe vem à mente, procurando deixar com que sua mente vagueie livre por onde e sobre o que quiser, o analista pode entender que aquilo que se diz está sendo determinado por um aspecto de sua realidade psíquica, portanto que a mente não está livre como aparentemente pode parecer. Sua correspondente atenção livremente flutuante pode apreender as direções para as quais as associações do paciente são dirigidas e perceber que existem determinações ou mãos de direção, para onde todo o fluxo associativo do paciente dirige-se. Assim, o psicanalista pode interpretar, quando intui qual é esse ponto para o qual os fluxos associativos dirigem-se. Seu ponto é, portanto, um elemento, a princípio, indeterminado; podemos dizer que é um objeto não sensorial.

O psicanalista precisa ter seu objeto diante de si. Ocorre que, para a psicanálise, o seu objeto - o inconsciente - não se deixa revelar a não ser que paradoxalmente se oculte de modo simultâneo e inexorável. O objeto psicanalítico - que estamos procurando ampliar neste trabalho para uma formulação acerca do Real - não é um objeto fenomênico e também não é a 
expressão concreta e sensorial que se exprime por meio de uma palavra. Qualquer formulação sobre o inconsciente do paciente não será o próprio inconsciente e, por isso, não determinará definitivamente a realidade do seu objeto. Portanto, há na psicanálise um paradoxo: se procuramos definir nosso objeto de estudo, teremos, com isso, inevitavelmente nos distanciado da possibilidade de sua apreensão. A interpretação deve mostrar para onde nosso olhar deve ser remetido, não para a coisa mostrada; isso porque a linguagem é um desenvolvimento humano que não foi criado com a intenção de expressar verdadeiramente sentimentos e emoções. Há uma tarefa mais importante: a de esconder e dissimular, tal como nos mostra Sandler (2008):

A linguagem, como observou Bion (por exemplo em Emocional Turbulence, 1977), é um desenvolvimento humano que não foi criado para expressar sentimentos nem emoções. Voltaire insistia: o dom do discurso é usado para esconder e dissimular o que realmente se pensa. Freud, que a nosso ver (Sandler, 1997, 2001), vindo do Iluminismo e do Movimento Romântico, observa o paradoxo e desenvolve os insights polarizados de seus antecessores: neste esconder também se aloja a semente do revelar. Alguns empregam a linguagem com o objetivo de elucidar a verdade (Bion, 1970, p. 3), mas isso requer não só um talento para procurar a verdade, mas um talento para ultrapassar a concretude e sensorialização inevitavelmente embutidas na palavra. (p. 44).

A tarefa de procurar a verdade, se estiver ocorrendo, deve, portanto, ultrapassar a sensorialização da palavra para alcançar o desvelamento, com a presença de algo oculto, e o velamento no desvelado. O velado no desvelado pode resguardar na concretude da palavra o seu ultrapassamento: o inefável, o mistério ou a não verdade. A noção de aletheia expressa bem essa ideia:

$\mathrm{O}$ velamento recusa o desvelamento à aletheia. Nem o admite até como steresis (privação), mas conserva para a aletheia o que lhe é mais próprio, como propriedade. O velamento é, então, pensado a partir da verdade como desvelamento, o não-desvelamento e, desta maneira, a mais própria e autêntica não-verdade pertencente à essência da verdade. $\mathrm{O}$ velamento do ente em sua 
totalidade não se afirma como uma consequiência secundária do conhecimento sempre parcelado do ente. $\mathrm{O}$ velamento do ente em sua totalidade, a não-verdade original, é mais antiga do que toda revelação de tal ou tal ente. É mais antiga mesmo do que o próprio deixar-ser que desvelando, já dissimula e, assim, mantém sua relação com a dissimulação. O que preserva o deixar-ser nesta relação com a dissimulação? Nada menos que a dissimulação do ente como tal, velado em sua totalidade, isto é, o mistério. Não se trata absolutamente de um mistério particular referente a isto ou àquilo, mas deste fato único que o mistério (a dissimulação do que está velado) como tal domina o ser-aí do homem. (Heidegger, 1930/1984a, p. 141).

Nessa complexa e profunda passagem, Heidegger (1930/1984a) incita-nos uma reflexão sobre aquilo que é o mais característico da aletheia (Natureza, Ser): seu velamento originário e, portanto, sua não verdade original. Sua reflexão indica-nos que, mesmo quando o ente desvelase, sendo em sua presença (aí), ele já se dissimula, ou seja, mantém uma relação entre seu desvelamento e sua dissimulação, a não verdade originária. Essa relação é a própria essência da verdade do ser; isso quer dizer que, mesmo no desvelar pelas palavras, gestos e ações, já há a dissimulação como uma característica fundamental do próprio desvelar. Portanto, o desvelar não pode ser simplesmente caracterizado como a "verdade" do ente e o ocultamento, como a “dissimulação" ou a mentira. Ambos estão intimamente relacionados.

A palavra, tomada puramente como algo sensorializado, não se torna capaz de oferecer a abertura para a não verdade originária a que Heidegger (1930/1984a) refere-se. Ela precisa, portanto, ser capaz de desvelar, mas simultaneamente de manter sua capacidade de abrir-se para aquilo que ainda não se tornou palavra, gesto ou desvelamento. Há, desse modo, um além da palavra, um mistério que determina essencialmente a palavra e a narrativa. "Segundo este conceito de sombra [como testemunho manifesto da luminosidade oculta], entendemos o incalculável como aquilo que, apesar de estar fora do alcance da representação, se manifesta no ente e assinala o ser oculto.” (Heidegger, 1938/1998, p. 90). Essa sinalização do oculto, um assinalar não representado, pode estar presente na palavra e na narrativa, que se mantém aberta tanto para o pensamento, ou seja, para o devir e o movimento do pensar, quanto para o 
acontecimento da alteridade/diferença. O desvelado deve, assim, manter-se como abertura para o oculto e não como figura acabada e luminosa da realidade mediana.

Há uma passagem escrita por Bion (1965/2004a), em seu livro Transformações, que nos indica que esse desvelamento precisa ter justamente essa direção: a direção desse aspecto mais fundamental, da não verdade original, para o desvelado ou - nas palavras do autor - da “divindade” para a sua encarnação:

Caso eu esteja correto em sugerir que fenômenos são conhecidos, mas realidade é tornar-se, a interpretação precisa fazer mais do que ampliar conhecimento. Pode-se argumentar que isto não é uma questão para o analista e que ele pode apenas ampliar conhecimento; que os passos seguintes, necessários para transpor o hiato, precisam emanar do analisando; ou de um aspecto específico do analisando, qual seja, sua 'divindade', que precisa consentir ser encarnada na pessoa do analisando. Parece haver aqui uma questão de 'direção': é diferente, a 'divindade' consentir em ser encarnada na pessoa do analisando, do analisando consentir 'tornar-se' deus ou a 'divindade' da qual 'deus' é a contraparte fenomenológica. A segunda situação sempre pareceria estar mais próxima da insanidade do que da saúde mental. (p. 162-163).

As palavras dissimuladoras apenas podem oferecer ao paciente o conhecimento sobre um acontecimento a respeito dele mesmo, mas esse desvelamento, que é compreendido como a realidade psíquica, parece justamente indisponibilizar o analisando com que aquilo que lhe é mais originário, para que possa tornar-se aquilo que puder se tornar, quando consentir em se tornar tal realidade, tal "luminosidade oculta". Ou seja, as palavras que interpretam deveriam sempre ter uma relação com o velado, com a não verdade originária, para que pudessem manter o analisando aberto para aquilo que ele ainda não se tornou e que pode vir a se tornar. A não verdade original de Heidegger (1930/1984a) parece ser aquela possibilidade de o analisando tornar-se aquilo que não adianta ser explicitado pela palavra; parece ser, desse modo, um centro fugidio, um mistério. Não se trata somente de um limite à linguagem, mas de algo que não se converterá jamais em representação (Figueiredo, 1995). 
Essa mudança de direção parece ser fundamental no método bioniano: ela compreende que não caberá ao analista fazer com que seu paciente torne-se algo. Esse tornar-se somente é possível por meio de uma direção inversa: a direção de um acontecimento no analisando, o qual é um acontecimento existencial, um "tornar-se". Trata-se de um "tornar-se" que não tem relação com aquilo que o paciente quer ser, mas com aquilo que é "consentido" tornar-se. Embora Bion (1965/2004a) use o termo 'divindade', sabemos que esse uso não pode ser identificado com uma forma de pensamento religioso no sentido usual do termo. Parece-nos fundamental destacar que esse tornar-se não é senão um acontecimento que se assemelha a uma visitação, ou seja, a algo (“divindade”, “O”, “Ser” ou "Real”) que não é nem conhecido nem representado, que inesperadamente acomete o analisando, de modo que o transforma. Trata-se de um visitante inoportuno e inesperado que, após o susto inicial de sua presença, amplia ou expande nossa visão sobre aquilo que ocorre em regiões e territórios impossíveis e desconhecidos, mas com a marca de ser um visitante que faz a nós mesmos sua realidade oculta; assim, amplia fundamentalmente a nossa própria existência, como uma existência simultaneamente una e múltipla.

\subsection{Uma Nova Questão e os Objetivos do Trabalho}

Como podemos saber distinguir, desse modo, em quais circunstâncias ocorre a presença do Real? Saberemos, assim, distinguir essa presença do seu oposto, ou seja, do seu esquecimento nas sessões de psicanálise?

Podemos dizer que nosso propósito é, portanto, verificar quais são as relações existentes entre o Real e os fatos clínicos psicanalíticos, ou seja, saber se os fatos clínicos presentes em sessões nas quais esteja ocorrendo psicanálise são ou não a expressão da atitude que o analista e o paciente têm diante do Real. Pretende-se saber quando e em quais circunstâncias podemos 
afirmar que tal interpretação ou situação presente em uma sessão teve a presença do Real e em quais situações podemos identificar a ocorrência de um esquecimento do Real e, conjuntamente, um velamento de sua verdade. Para tanto, tencionamos explorar essas ideias e expandi-las.

Por fim, pretendemos qualificar, mesmo por meio de qualificações negativas, o Real e, para isso, saber distingui-lo de outras ocorrências dentro das sessões. Nesse sentido, buscaremos, pela psicanálise, não somente aquilo que é a realidade psíquica, mas aquilo que é a visitação do Real, possivelmente oculto, em sua não verdade originária, por meio da realidade psíquica que tece sua teia sobre o fundo de nossa origem, do qual nada sabemos ao certo. 


\section{NARRATIVAS CLÍNICAS PSICANALÍTICAS}

Ricoeur (2010), em seu trabalho A vida: uma narrativa em busca de um pensador, fala-nos sobre a tarefa interpretativa que se encontra no ato da narrativa, tão especialmente importante na tarefa de o homem compreender-se. Para o autor, quando não interpretada, a vida mantém-se tão somente como um fenômeno biológico. Interpretar a si mesmo é narrar aquelas histórias pessoais examinando-se; é manter uma atitude dialógica - mesmo consigo próprio - que cria, ao interpretar, justamente uma ficção narrativa que nos conduz para a compreensão de nós mesmos. Ele nos diz:

Pode-se dizer que o indivíduo parece 'emaranhado em histórias' que lhe acontecem antes que toda história seja narrada. O emaranhamento aparece então como a pré-história da história narrada cujo começo permanece escolhido pelo narrador. Essa pré-história da história é o que liga esta última a um todo mais vasto e lhe proporciona um pano de fundo. Esse pano de fundo é feito da imbricação viva de todas as histórias vividas. É preciso então que as histórias narradas surjam desse pano de fundo. Com esse surgimento, o sujeito implicado também surge. Pode-se então dizer: a história é responsável pelo homem. A conseqüência principal dessa análise existencial do homem como ser emaranhado em histórias é esta: narrar é um processo secundário implantado em nosso "ser emaranhado em histórias". Narrar, seguir, compreender as histórias é tão só a continuação dessas histórias não ditas. [...] Se é verdadeiro que a ficção só se finaliza na vida e que a vida somente se compreende por meio das histórias que narramos sobre ela, decorre que uma vida examinada, no sentido da palavra que tomamos emprestado no início de Sócrates, é uma vida narrada. (Ricoeur, 2010, p. 208-209).

Emaranhados em histórias não ditas, encontramo-nos selecionando, escolhendo, dando continuidade e repetindo aquelas partes desse emaranhado que parecem ser passíveis de interligação e costura. Com essas costuras, fazemos desse emaranhado de histórias, simultaneamente, recortes e cisões, mas com a finalidade de produzir as costuras para uma história que possa ser também narrada por meio de uma compreensão possível. Tornamo-nos 
autores de nossas histórias, enquanto esse emaranhado de histórias - nosso pano de fundo procura um autor que as conte; e também tornamo-nos autores das histórias dos outros, quando examinamos justamente aquele emaranhado de histórias vividas na análise de alguém - e por que não dizer de pensamentos oníricos inconscientes -, interpretando e traduzindo em palavras que nos pareçam ser o prolongamento de algo que conhecemos de uma narrativa que já foi anteriormente contada, ou por nós mesmos ou por outros. No entanto, ao formularmos narrativas quando estamos apenas contando aquelas histórias que já foram anteriormente contadas, quando criamos analogias entre uma história possível e outra história escutada, outro caso clínico, parecemos, assim, sobrepor uma história na outra e interpretá-las a partir da ideia de que são possuidoras de modelos semelhantes, feito que se fundamenta na teoria clínica, que pode ser a expressão de uma mesma lógica presente em fenômenos distintos, que se tornam, por elas, narrativas de histórias semelhantes. Assim, pensamos que as narrativas devem sempre ter em vista esse emaranhado de histórias, que é o nosso verdadeiro pano de fundo dos pensamentos oníricos inconscientes e, mais além, do Real.

Criar histórias, interpretando a vida, é narrar uma ficção que possa ser constantemente recriada, que possa ser sempre expandida aos seus limites de possibilidades. Ficção significa somente criar e recriar histórias que tenham o pressentimento de que há uma multiplicidade de histórias que pedem para ser contadas, que clamam por um narrador e que, ao invés de contarmos todas elas, ficcionamos uma ou outra história, que se torna narrativa. Para isso, para essa tarefa de contar nossas histórias, parece que sempre precisamos de modelos, que podem ser teóricos, psicanalíticos, mitológicos, religiosos, ambos ou algum outro, de modo que dificilmente encontraremos narrativas absolutamente originais, no sentido de serem desprovidas de modelos de referência. Isso quer dizer que podemos, na clínica psicanalítica, procurar fazer uma relação entre esses modelos e a possibilidade de, por meio deles, expandirmos nossa possibilidade de apreensão da realidade psíquica palimpséstica. 
Amadurecimento e expansão parecem estar em relação, ou seja, parece haver uma relação entre a possibilidade de nossos pacientes expandirem suas narrativas por meio de modelos e a tarefa de amadurecimento ou maturação do psiquismo para poder ampliar a interpretação que se faz da própria vida. A narrativa é, assim, a expressão dessa expansão e ocorre sempre por conta de certo amadurecimento que a possibilitou. Uma expansão parece ser algo que não tem um fim determinado, tal como sabemos, pois ela nasce dessas histórias que procuram um autor para si, que possa contá-las, narrá-las e, assim, tornar-se não apenas mais conhecedor de si mesmo, mas sujeito e autor dessa história que sempre pede para ser recontada e sempre nos sugere um contar diferente. O mito de Édipo parece ser um bom exemplo desse modelo de referência, mas desenvolveremos esse assunto a seguir.

Neste capítulo, nosso propósito será o de formular ficções narrativas; ficções que são, portanto, exames e interpretações. Essas interpretações e exames são, no entanto, falsificações, no sentido de que "a verdade absoluta não pode jamais ser conhecida diretamente" (Symington \& Symington, 1996, p. 177); talvez, por meio de narrativas e exames que são, de alguma forma, ficcionais, conheçamos apenas suas transformações na narrativa. Há uma famosa preposição psicanalítica que diz: a clínica é soberana. Podemos dizer, reafirmando-a, que a clínica é soberana para a apreensão da ficção narrada, a qual apenas é possível quando podemos perceber a existência de todas as histórias latentes e que jamais foram narradas, desse pano de fundo de verdade intraduzível em sua totalidade, de uma alteridade radical e impronunciável.

Empregaremos nosso método palimpséstico nos fatos clínicos psicanalíticos, nesse emaranhado de histórias que podemos chamar de pré-história da história contada. Iremos, assim, descrever tais fatos clínicos por meio de narrativas e extrair delas aquilo que corresponde ao nosso método, ou seja, a apreensão da realidade desconhecida que ocorre em meio aos pensamentos oníricos inconscientes sobrepostos em camadas e, ainda, a sua 
permeabilidade aos elementos vazados que se encontram entre as escritas, caracterizados como o próprio Real. Nosso propósito, dessa forma, será o de pesquisar, por meio da psicanálise como método de investigação, a existência desses elementos vazados e, quiçá, poder caracterizá-los como elementos presentes nos fatos clínicos psicanalíticos. As histórias por nós narradas serão, portanto, também uma tentativa de escrita que procurará manter-se sempre como uma interpretação inconclusiva, como falha, como interpretação e exame que sempre nos deixem dúvidas que nos permitam buscar, nesse "pano de fundo", a sua origem desconhecida.

No entanto - e aqui vale uma advertência -, nosso propósito não será o de empregar um método de trabalho em que as histórias narradas busquem conduzir o paciente para aquilo que foi caracterizado por Bion (1965/2004a) como transformações em “O”, ou melhor, para a encarnação da realidade última, ou do Real, de modo que o paciente tenha acesso direto à realidade desconhecida, independentemente de um conhecimento sobre ela. Isso se deve ao fato de que procuramos, com essas narrativas, mostrar que o Real parece estar presente como possibilidade de visitação, mesmo sem que o método de trabalho seja o de um posicionamento do analista no Real para a condução das sessões a partir dessa estranha posição. Além disso, nossas narrativas propõem ser observações, por meio dessas histórias contadas, dos acontecimentos do Real, sob o modo do reconhecimento de sua visitação, simultaneamente podendo expressar os modos de seu esquecimento nas sessões, tema que será desenvolvido com maior precisão em nosso sexto capítulo.

Serão apresentadas três narrativas clínicas, mas essas narrativas não devem ser compreendidas exatamente como casos clínicos. A intenção é conservar o anonimato das pessoas que deram origem a tais relatos clínicos e, portanto, seus dados factuais foram alterados significativamente. Além disso, pensamos que elas têm apenas a função de explicitar a visitação incompreendida, inapreendida do Real nas narrativas clínicas e de 
explicitar o seu esquecimento. Não queremos, portanto, apresentar casos clínicos para uma discussão sobre tais pacientes, mas pensar, por meio desses pacientes, aquilo que se encontra além da ficção, além da narrativa, além do exame do sujeito e do autor.

O propósito, em geral, é apresentar situações que se aproximem não de uma experiência com o Real, mas de como o Real estava latente, como uma possibilidade de visitação que parece ter sido constantemente esquecida ou como um acontecimento esquecido; logo, não iremos narrar fatos da vida que pareçam apenas nos distanciar desse objetivo. As três descrições podem, assim, ser consideradas simplesmente vinhetas literárias e clínicas, e não têm por compromisso expressar a totalidade da vida emocional de alguém; nesse sentido, não são diagnósticas. Evocamos os trabalhos de Leclaire (1992) e de Khan (1991) como expressões desse trabalho de produção narrativa de casos clínicos, que, tal como este, podem certamente ser compreendidos como literatura, narrativas ficcionais de literatura psicanalítica.

\subsection{Rei Posto, Rei Deposto e a Cabeça Costurada: a Orfandade e o Anseio pelo Rei}

É o orgulho de jovens escolares que se amotinaram em aula e expulsaram seu mestre. Mas a alegria dos garotos terá fim e lhes custará caro. Derrubarão os templos e inundarão a terra de sangue. Mas perceberão por fim, essas crianças estúpidas, que são apenas fracos revoltosos, incapazes de revoltarem-se por muito tempo.

F. Dostoiévski

Iniciaremos esta primeira narrativa clínica dizendo que há uma passagem escrita por Freud (1930/2006c), em O mal-estar na civilização, que fez com que iniciássemos uma reflexão sobre o tema da paternidade em um exame de uma paciente que compreendemos, durante longa parte do trabalho analítico, como tendo basicamente uma característica histérica. Dizemos isso 
porque, de um modo geral, não se apresentavam traços psicóticos e sua orientação moral não dava margem para suscitar hipóteses amorais ou pervertidas, mas, além disso, detivemo-nos na tentativa de ajudá-la a compreender que certos sintomas fóbicos, como, por exemplo, seu medo de dirigir automóveis, tinham como origem uma relação conflitiva emocional com as figuras materna e paterna, de um ponto de vista edipiano, sobre o qual não nos deteremos agora.

A reflexão sobre o tema da paternidade começou a se tornar cada vez mais fértil e, embora ele também estivesse articulado com a problemática edipiana, não estava se revelando amplo o suficiente, até que essa reflexão ampliou-se, ao seu tempo, para o tema da orfandade. Gostaríamos de poder comunicar essa ampliação, descrevendo, inicialmente, três tempos presentes nessa histeria e, posteriormente, pensar no tema da orfandade como subjacente à novela histérica que se desenrola nesse caso clínico.

Essa passagem de Freud (1930/2006c), inicialmente, parece ser uma remontagem imaginativa do início de nossa civilização, em um daqueles devaneios freudianos que parecem ser provenientes de um sonho, ou algo como um sonho, e que procuram pictoricamente representar alguma verdade emocional obscura. Citamos:

Em época ainda anterior, em sua pré-história simiesca, o homem adotara o hábito de formar famílias, e provavelmente os membros de sua família foram os seus primeiros auxiliares. Podese supor que a formação de famílias deveu-se ao fato de ter ocorrido um momento em que a necessidade de satisfação genital não apareceu mais como um hóspede que surge repentinamente e do qual, após a partida, não mais se houve falar por longo tempo, mas que, pelo contrário, se alojou como um inquilino permanente. Quando isso aconteceu, o macho adquiriu um motivo para conservar a fêmea junto de si, ou, em termos mais gerais, seus objetos sexuais, a seu lado, ao passo que a fêmea, não querendo se separar de seus rebentos indefesos, viu-se obrigada, no interesse deles, a permanecer com o macho mais forte. (Freud, 1930/2006c, p. 105).

Poderíamos ler essa passagem de maneiras diversas, mas nos interessamos especialmente pela ideia de que a fêmea ver-se-ia obrigada a permanecer com o macho mais 
forte. Bem, não nos parece um equívoco afirmar que o macho mais forte seria aquele que garantiria a possibilidade de sobrevivência para esse pequeno grupo e que os rebentos seriam indefesos e a fêmea desejosa de proteção. $\mathrm{O}$ macho, por sua vez, enquanto pudesse ter a fêmea junto de si como objeto sexual, defenderia e protegeria todo o grupo, sendo por todos considerado forte e indispensável para a manutenção da estrutura dessa família pré-histórica.

\subsubsection{O Rei Posto}

Essa mulher, que atendemos há vários anos, descobriu, no curso da análise, sua predileção por homens fortes. Ela tem uma pequena filha, nascida em seu segundo casamento, que durou cerca de sete anos. O início desse casamento é descrito como uma fábula maravilhosa, em que ambos viviam deslumbrados com seu amor e vivendo dias e noites de Hollywood, ou seja, narrava uma época passada, em que seus desejos pareciam ser inteiramente satisfeitos.

Durante uma parte significativa dessa união, que tivemos a possibilidade de acompanhar, observamos que seu desejo por um homem forte era sempre frustrado pelos constantes enfraquecimentos de seu marido, em episódios descritos como de impotência e depressão. Nesses episódios, essa mulher alternava seu humor entre uma enorme disposição para fazer com que ele se fortalecesse, enchendo-se e enchendo-lhe novamente de ânimo, e uma profunda indisposição, que parecia levá-la para o fundo de um profundo abismo. Quando dizia que seu marido novamente recobrara seu ânimo, ela incrivelmente restabelecia-se, sem deixar de sentir, no entanto, um sentimento que viemos a entender posteriormente como sendo de culpa, do qual trataremos a seguir.

Assim que seu marido recuperava-se e podia voltar a trabalhar com ânimo, acreditando que poderia ganhar muito dinheiro e realizar as inúmeras coisas que havia prometido para ela, 
como viagens fantásticas, apartamentos grandes e luxuosos, e grande conforto material e emocional, ela se entregava a seus devaneios e sentia que o futuro maravilhoso, tal como havia sido aquele passado, estava batendo à sua porta. Nesses momentos, para ela, seu marido tornava-se aquilo que se poderia considerar um homem forte. Eram promessas que expressavam o anseio de rompimento do círculo vicioso da insatisfação do desejo por uma vida em que as vontades pudessem ser constantemente satisfeitas e a plenitude vivida integralmente, tal como no imaginado início do casamento.

Parece-nos que o aspecto mais visível do seu desejo, nesse caso, era o de possuir um objeto amoroso que satisfizesse completamente os aparentes anseios oriundos da incompletude: aquele ou aquilo que apaziguaria o ciclo interminável de objetos que jamais conseguem por fim à inquietude do desejo insatisfeito. Sobre isso, havia uma espécie de mote em nossas conversas, que sempre estava presente: o mote do docinho inalcançável:

Então, eu acho que já contei isso para você antes... eu vejo meu irmão, meu pai, estávamos na casa daquela senhora e (ri) ficávamos sentados bonitinhos naquele sofá... e tinha aquela travessa de docinhos em cima da mesa, e eu imaginava um braço, um braço enorme, grande, que ia até lá e pegava aqueles docinhos... mas tinham dito para nós dois [ela e o irmão]: 'vocês não podem comê-los... o que vão pensar os outros, que vocês não comem em casa?' e nós ficávamos sentadinhos naquele sofá enquanto a senhora dizia para meus pais como éramos bem comportados, como éramos bem educados...

Em nossas inúmeras conversas, esses docinhos transformaram-se nas mais variadas coisas: trabalho, namorado, sexo, dinheiro, família, atividade profissional, atividade de lazer, seus próprios pensamentos e em docinhos mesmo. Os mais variados objetos eram descritos de modo a nos fazer entender que, com eles, a paciente possuía certa distância, uma distância do inalcançável, e que havia entendido que pegar o docinho era sinal de que havia uma necessidade dela - e ela deveria se parecer com alguém que não tinha necessidades. Sua vontade era, certamente, pegar os docinhos, mas a ideia de que isso se converteria numa expressão de uma 
necessidade e, principalmente, de que essa necessidade poderia ser rechaçada por alguém, além de ser um enorme medo seu, era sua explicação para inumeráveis problemas de sua vida relacionados com a expressão do querer. Esperava, portanto, que alguém pudesse fazer isso por ela: pegar os docinhos e oferecer a ela, que aceitaria sem demonstrar se era sua real vontade ou não. Parecia ser essa uma das funções de seu marido.

\subsubsection{Um Rei Deposto}

A dissolução do matrimônio iniciou quando essa mulher começou a se queixar de não ter os docinhos que queria sendo-lhe oferecidos, como não se ver mais atendida emocional e sexualmente, e quando percebeu que seu marido passava um enorme tempo na internet comunicando-se com outras mulheres. Seu ódio por esse marido passou a se tornar enorme para ela, de modo que ele não podia mais se tornar um homem forte por um tempo razoável sem que fosse deposto de seu lugar pela fúria intermitente da paciente. Como pudemos perceber posteriormente, essa sua dinâmica tornou-se aparente para nós apenas após o início de sua crise com o marido, mas compreendemos que essa situação mental era anterior e inaparente, sendo que, mesmo durante a análise, nos tempos anteriores a essa crise, ela não aparecia.

A chave para uma parcial compreensão de sua dinâmica veio em uma sessão, algum tempo depois de sua separação, na qual considerou que seu atual namorado não estava interessado mais nela. Após algum tempo de conversa, pudemos perceber que era ela, e não o namorado, que andava pouco interessada no relacionamento e isso decorria do fato de que o namorado teria dito para ela que estava com problemas no trabalho. Esse fato desencadeou nela duas associações: a primeira era sobre o presente que havia ganhado de seu ex-marido, um presente caro, dado por um homem "forte"; e a segunda era de como sempre se relacionava com homens fracos, depressivos e que tinham problemas no trabalho. Alguns indícios provenientes 
de material de fora das sessões informavam-nos que tanto seu ex-marido quanto seu atual namorado eram homens que estavam relativamente bem financeiramente; ambos sócios de empresas do setor imobiliário e jurídico. Cabe destacar, também, que a paciente não trabalhava, embora tivéssemos nos dedicado ativamente sobre essa questão durante todo o último ano de atendimento.

Os problemas no trabalho do namorado fizeram-nos perceber que seu interesse por homens fortes e homens que poderiam se tornar ainda mais fortes, de modo que a paciente pudesse ficar inteiramente dedicada a cuidar para que ele permanecesse sempre forte, antecedia sempre um período sentido por ela como de tirania dos seus companheiros, que basicamente podia ser resumido como um sentimento de dependência do tirano, das vontades do tirano e de uma diminuição do desejo do tirano por ela. Ou seja, quanto mais ela queria que o companheiro tornasse-se rei, para que ela vivesse com um companheiro forte que a desejasse como objeto sexual e amoroso, mais esse rei tornava-se aos seus olhos um tirano, com quem passava a ter um relacionamento que era um misto de atração e de desconfiança, um misto de admiração e de inveja, além de uma raiva por ter colocado no poder um homem que agora apenas pensava em seus próprios interesses egoístas e não mais na realização das vontades dela. Aparentemente, tratava-se de um reinado absolutista e, por fim, a paciente ficava absolutamente dependente e submissa.

Freud (1930/2006c) expôs uma situação semelhante em outra descrição dos primórdios da vida familial:

Não devemos esquecer, contudo, que na família primeva apenas o chefe desfrutava da liberdade instintiva; o resto vivia em opressão servil. Naquele período primitivo da civilização, o contraste entre uma minoria que gozava das vantagens da civilização e uma maioria privada dessas vantagens era, portanto, levada aos seus extremos. (p. 119-120). 
No entanto, no submundo da paciente, criava-se o anseio pela revolução e ela iniciava seus planos para a deposição de seu rei tirano. Assim, em algum momento, seu "impulso" revolucionário vinha à luz do dia e, além de tomar a praça pública gritando palavras de ordem, com imensa energia e força, decapitava o rei em praça pública, para o mundo todo assistir. Poderia ser dela a frase, parodiando Nietzsche: "O rei [Deus] morreu, e fui eu que o matei!" Afinal de contas, na filosofia, Nietzsche (1888/1978c) parece ter sido o primeiro a indicar que havia um ímpeto humano para o assassinato do pai; segundo ele, para o estabelecimento de novos horizontes para que os homens pudessem descobrir novas "terras" e novas possibilidades; em Freud (1913/2006p), para que os primevos estabelecessem uma cultura fundamentada na divisão equitativa dos objetos sexuais e do prazer.

\subsubsection{Cabeça Costurada}

Parecia, então, haver-se concluído sua história imaginária; mas não. O fato é que, após esses acontecimentos, pudemos observar durante a análise duas outras coisas. A primeira foi o fato de que, após a decapitação do rei, o reino todo entrava em confusão e a paciente passava a sentir que não conseguiria sozinha comandar seu país e proteger a si mesma; sentia-se sozinha e desamparada. A segunda foi o sentimento de culpa desencadeado após a decapitação do rei tirano. Na verdade, essas histórias foram contadas por nós dois durante as sessões que se seguiram à ocasião em que o namorado estava com problemas no trabalho. De certa forma, divertíamo-nos com o fato de ela decapitar os homens; havia muito humor nisso, embora se tratasse de um humor com grande dose de angústia e culpa.

Em uma das sessões em que conversávamos sobre esse assunto, a paciente, após um breve silêncio, disse que se sentia culpada sim, mas que o maior problema era que, após a decapitação do rei, ela costurava a cabeça dele para ficar de novo em seu lugar. Chamou-nos 
muito a atenção esse comentário e percebemos que a paciente, ainda que procurasse fazer alguma reparação por conta da violência com que agia na tomada do poder, mantinha uma relação com o rei deposto e costurado, que era a de inflá-lo novamente, embora soubesse, desde sempre, que isso seria um remendo e que seu rei nunca mais poderia ser o rei tirano "original". As marcas da decapitação eram extremamente visíveis e isso fazia com que ela tivesse que se esforçar ainda mais na tarefa de inflar o rei como um balão vazio, que lhe parecia deprimido e fraco.

Pudemos observar que todo rei posto tornava-se tirano quando a paciente engrandecia-o com a intenção de fazer com que ele se encarregasse de cuidar dela e da realização de seus desejos. O rei, por sua vez, parece que não se furtava a esse papel; muito pelo contrário, oferecendo-se a ele, aguardava seu engrandecimento com naturalidade e, em troca disso, ofertava o que nunca tinha realmente para dar: uma espécie de longos braços para alcançar o docinho inalcançável. A paciente, por sua vez, não queria aquilo que ele realmente lhe dava. $\mathrm{O}$ rei mentia sobre sua capacidade de dar; a paciente mentia sobre sua aceitação e docilidade. O rei deposto não se configurava uma mudança revolucionária e a costura fazia do rei um fantoche empossado às pressas por um povo desejoso de sonhos antigos... um estranho sonho da vida anterior à deposição do pai monopolizador que dominava e protegia.

Durante sua análise, certamente não ficamos sem nos haver com essa dinâmica mental, que parecia temporalmente dividida, mas que parecia ser simultaneamente existente, como escritas de um palimpsesto; e, nas sessões, a paciente queixava-se com frequência do fato de que éramos demasiadamente monocórdicos e isso queria dizer que falávamos sempre num mesmo tom. Quando nos entusiasmávamos com algum assunto e, naturalmente, tínhamos alguma reação imprevista, ela, além de reparar, procurava nos dizer que gostava quando era assim. Foi quando começamos a sentir que nossa garganta talvez já estivesse cortada e ela estivesse nos inflando feito um balão vazio, para depois costurar nossa cabeça. Quando 
permanecíamos em silêncio, escutando suas histórias, parecia-nos que se tratava de uma paciente que exigia muito pouco, não nos fazendo perguntas sobre seus problemas e aparentemente fazendo o trabalho de análise sozinha. Nesses momentos, sentíamos que estávamos desvitalizados, sem forças; a paciente, por sua vez, esforçava-se para que o nosso reino mantivesse-se funcionando e, tal como na história de Arthur, o reino não adoecesse junto a seu rei, nesse caso, um rei que teria que fingir que a fúria de seu povo não tinha sido exercida contra ele. Assim, permanecia a paciente ao lado do rei com cabeça costurada.

Ocorria, outrossim, uma situação peculiar de conflito: seu desejo por homens fortes era desiludido pelos objetos que não se sustentavam, sendo que sua luta contra eles começava quando aparentemente o rei estava mais forte; após sua decapitação, com a costura da cabeça, o rei devia ser inchado até que se transformasse em uma espécie de balão, cheio do ar que ela inflava. Enquanto a paciente mostrava-se submissa perante um rei forte, este, ingenuamente, não percebia a força ardilosa que tanto colocava quanto tirava do poder esse rei que era, verdadeiramente, um rei fantoche; e como rei fantoche, de cabeça costurada, não era sentido mais como um homem forte, de quem pudesse sentir admiração e que, principalmente, pudesse lhe admirar.

\subsubsection{Decapitação e Orfandade}

Pareceu-nos, assim, que a paciente repetia uma situação na qual se tornava sem rei, com a crença onipotente de que isso era decorrente de sua atividade agressiva. Lembramonos, em uma das sessões, de Totem e tabu (Freud, 1913/2006p), sobre o assassinato do pai, e de que o sentimento de culpa era a consequência de um ato de agressão que fora executado.

Sem dúvida, tratava-se de uma paciente que vivia fortes sentimentos de culpa. No entanto, parece-nos que, nesse caso, a morte do (rei) pai seria realizada de forma repetitiva, 
representada como uma espécie de decapitação do rei, e que o rei, ou esses reis, não seria mais do que uma atualização da imago paterna. Passamos, portanto, a inverter a perspectiva e a compreender que a paciente poderia estar querendo elaborar uma situação de ausência sempre pressentida por ela: a de que realmente não haveria um pai ou um rei ou uma mãe com quem se poderia contar desde o início, tal qual órfãos ansiando por paternidade (Safra, 2007). Assim, o sentimento sempre presente de orfandade, intolerável e Real, poderia ser o desencadeante de uma situação repetitiva: a de fantasiar que a morte ou a ausência do rei-pai seria fruto de sua atividade agressiva, como uma tentativa de controle onipotente da solidão ou do desamparo da orfandade.

As divergências sobre uma condição originária fundamental do ser humano, em se tratando de psicanálise, são enormes. Winnicott (1963/1982b), em Comunicação e falta de comunicação levando ao estudo de certos opostos, parece ter se aproximado de uma concepção na qual a solidão humana era-lhe inerente e inexorável; sua comunicação seria feita a partir dessa condição. O autor cita Fordham nesse trabalho, lecionando: "O fato geral permanece, que a experiência primordial ocorre na solidão.” (p. 172). O fato de se ter um pai e as características dessa ou daquela paternidade seriam, portanto, sempre posteriores ao fato de que a solidão humana não só seria anterior a qualquer tipo de paternidade, como origem do anseio que possibilita ao homem ter uma paternidade. Ou seja, segundo esse ponto de vista, a solidão primordial do homem, experimentada ainda no início da vida, não somente é a condição a partir da qual a comunicação origina-se, como aquilo que caracteriza o anseio por não se estar só. 


\subsubsection{A Solidão e as Âncoras no Porto}

Encontramos também, no movimento psicanalítico, outras ideias sobre esse problema. No trabalho de Winnicott (1958/1982a), A capacidade para estar só, há alguma referência a trabalhos anteriores de Klein, que se tornam ideias também exploradas pelo autor, como a de que "a capacidade de ficar só depende da existência de um objeto bom na realidade psíquica do indivíduo" (p. 34) e, ainda, de que "maturidade e capacidade de ficar só significam que o indivíduo teve a oportunidade através de maternidade suficientemente boa de construir uma crença num ambiente benigno" (p. 34), ou seja, de que haveria uma crença na preponderância de bondade nos objetos e, portanto, dos objetos, acima de sua possibilidade de serem destrutivos ou malignos. ${ }^{21}$ Winnicott (1958/1982a) ainda nos diz que "essa crença se constrói através da repetição de gratificações instintivas satisfatórias.” (p. 34). Não discutiremos, neste trabalho, o papel da crença na formação do eu primitivo, tese que já estava formulada em Klein (1946/2006), em seu trabalho Notas sobre alguns mecanismos esquizoides; de qualquer modo, para ambos os autores, haveria a necessidade da criança de manter a unidade de seu self por meio de uma crença na bondade do objeto com o qual se relaciona.

Esse uso que Winnicott (1958/1982a) faz das ideias kleineanas tem importância fundamental para salientar a tese principal desenvolvida nesse seu trabalho: a tese segundo a qual a capacidade de estar só depende da possibilidade encontrada pela criança de estar só na presença de mais alguém, ou seja, que apenas se consegue permanecer sozinho quando mais alguém está presente. Esse alguém presente seria o correlato interno de um objeto bom que alimenta e acalenta. Podemos afirmar, assim, que o autor destaca a importância do

\footnotetext{
${ }^{21}$ Podemos também propor que essa preponderância é fundamental para o processo de integração do ego, mas, conforme nos conta Klein (1946/1991), à medida que a integração avança, ela se torna mais difícil de ser aceita, uma vez que a aproximação dos impulsos destrutivos e dos aspectos maus do objeto desperta a ansiedade de que eles irão sobrepujar os aspectos bons do mesmo objeto. Com isso, o próprio ego poderá se ver novamente fragmentado, visto que sua coesão baseia-se justamente na preponderância do objeto bom instalado como seu aspecto nuclear.
} 
ambiente e das relações "reais" da criança com seu ambiente, bem como o papel da mãe ou de alguém disponível para ser o que a criança precisa no desenvolvimento de sua capacidade de reproduzir esse objeto bom, que poderá se instalar e se manter na mente da criança quando a mãe não está presente.

A presença ou a ausência da mãe na mente da criança já havia tido sua precedência, no entanto, em Freud (1920/2006e). Ao descrever o jogo do carretel, demonstrou que tanto a repetição quanto a possibilidade de dominar a ausência da mãe eram produzidas pela fantasia e tinham como propósito a diminuição de sentimentos de abandono e solidão. Com isso, o autor começa a pensar se a capacidade da criança em permanecer sozinha relaciona-se com a possibilidade de ela representar em sua mente a ausência e a presença da mãe, fantasiando onipotentemente que poderia ter um controle mágico disso. Por outro lado, o jogo demonstra também a necessidade da criança de poder manter em si um objeto bom, mesmo diante da frustração que surge pela mãe que se vai.

Winnicott (1958/1982a) procurou enfatizar que o contato com a mãe e as gratificações instintuais repetitivas seria a base para o desenvolvimento e a manutenção desse objeto bom que poderá se manter na ausência do objeto "real" gratificador, mas isso não difere em nada daquilo que pensava Klein (1963/1975). No seu trabalho Sobre o sentimento de solidão, ela diz:

Uma relação primitiva satisfatória com a mãe (não necessariamente baseada na amamentação ao seio, de vez que a mamadeira também pode simbolicamente representá-lo) implica em contato íntimo do inconsciente da mãe com o da criança. Isso é o fundamento para a experiência mais completa de compreensão e essencialmente se vincula ao estágio pré-verbal. (Klein, 1963/1975, p. 141).

Já no seu trabalho Notas sobre alguns mecanismos esquizoides, Klein (1946/2006) diz concordar inteiramente com o ponto de vista de C. M. Scott sobre a importância dos sentimentos de continuidade experimentados pela criança para o estabelecimento de um modo 
de relação com o objeto. Assim, não bastaria para a criança poder fantasiar, pois, ao sentir uma continuidade de seu fantasiar, uma continuidade temporal, ela teria a segurança de que a realidade seria estabelecida de seu ponto de vista, por exemplo, de que os objetos são divididos em bons e maus.

A relação primitiva com a mãe, descrita na citação anterior, que fundamenta o processo de introjeção do objeto bom, está na origem não só do processo de integração do ego, quando o objeto bom pode se instalar com relativa segurança e se constituir como o núcleo do desenvolvimento do ego, como também do próprio sentimento de solidão, uma vez que "na vida ulterior, pensamentos e sentimentos a uma pessoa afim, parece perdurar um anseio insatisfeito por uma compreensão sem palavras" (Klein, 1963/1975, p. 141), uma compreensão baseada numa relação que se perdeu. Desse modo, podemos afirmar que, tanto em Winnicott (1958/1982a) quanto em Klein (1963/1975), há uma compreensão clara da importância do papel da mãe (ou alguém que a substitua) no desenvolvimento emocional primitivo da criança, mas a relação feliz que a criancinha pode ter com sua mãe não está imune às tempestades provenientes de fontes internas e externas da vida, ou seja, as ansiedades persecutórias inevitavelmente poderão surgir em decorrência de vicissitudes da própria vida, como a fome, a dor, o desconforto, a doença, o sono e outras tantas de origem exógena. Além disso, como enfatiza Klein (1963/1975), o próprio desenvolvimento ulterior é a condição para que aquela origem compreensiva perdida passe a ser sentida como um anseio por algo que jamais se poderá obter novamente, por isso mesmo, a manutenção de um estado de solitude.

No trabalho de Klein (1963/1975), há fundamentalmente a assertiva de que a insegurança paranoide é uma das raízes do sentimento de solidão, surgindo principalmente quando os sentimentos de destruição parecem poder sobrepujar os sentimentos amorosos. Quando isso ocorre, o objeto bom que estava tendo preponderância na mente passa a ficar comprometido e ameaçado; podemos observar esse acontecimento na paciente após a fantasiada 
decapitação de seu rei. Esse comprometimento não se dá, no entanto, apenas em relação aos objetos do mundo, mas principalmente em relação ao próprio $e u$, ou seja, o sentimento de solidão e abandono surgiria quando os impulsos de destruição ameaçariam se aproximar e destruir aquilo que há de bom na mente. Esse objeto bom, que outrora era também o objeto compreensivo da própria mente, torna-se frágil. Nesse sentido, as ideias kleineanas aproximamse de uma perspectiva segundo a qual a mente humana, ao invés de ter de lidar com um estado de solidão inerente e fundamental, parece produzir esse sentimento pelo ataque ao bom objeto introjetado. Pensamos, porém, que essa atitude de ataque ao bom objeto apenas corrobora a tese, também infantil, de que a experiência de ausência e solidão seria produto do ataque e não que se trataria de um "registro" originário, que já estava presente no psiquismo: a solidão originária, que precisaria ser tratada como início das atitudes do sujeito em sua relação com seus objetos.

Mas retornemos à nossa paciente. Em determinada sessão, ela se voltou para um tema que era também recorrente: a de como seu namorado estava distante dela. Em determinado momento, interpretamos que ela mesma se mantinha longe dele pelo fato de ele não ser tão forte quanto ela gostaria que fosse. Ela desenvolveu essa conversa dizendo que havia ficado muito incomodada pelo fato de ele ter lhe ligado pela manhã e dito que estava ainda com alguns problemas que andavam lhe incomodando. A paciente disse, em tom irônico, que perguntou para ele se não gostaria, então, que ela lhe enviasse a um "spa", mas, na verdade, como veio a dizer depois, sua vontade era que o namorado dissesse-lhe para ela ir até lá ficar com ele, mesmo sendo uma terça-feira pela manhã. Espontaneamente, lembramo-nos de uma situação vivida em família, de um menino de dois anos e meio que perguntava constantemente a seu pai o porquê de ele trabalhar muito. Após essa lembrança ter sido rememorada, compreendemos que algo se passava sob o tema da separação e que a nossa interpretação sobre sua vontade de permanecer longe pelo fato de o namorado não ser um homem forte 
parecia não mais se sustentar. Na verdade, pareceu-nos que ajudamos a paciente a se explicar, fantasiosamente, que ela controlava a presença de alguém pelo seu desejo e que, se controlava a presença, então também controlaria a sua ausência.

Não pudemos deixar de lembrar o jogo do carretel (Freud, 1920/2006e) e a tentativa daquele menininho de obter um controle onipotente de sua mãe com esse jogo. Lembramonos também que, para o menininho de nossa família, nenhuma explicação parecia ser possível, ${ }^{22}$ pois se tratava da tentativa de elaborar aos poucos uma situação de ausência, da falta do pai e da reexperimentação da sua orfandade originária; cogitamos conosco mesmo se não era exatamente essa a fonte das angústias que essa paciente experimentava. Contamos a ela essa lembrança e sua reação foi enfática: "Você está me dizendo que eu tenho dois anos de idade?" Procuramos dizer que o problema não era a idade, mas a questão que se colocava. Na sessão seguinte, porém, após um momento de silêncio, a paciente disse que aquilo que havíamos falado sobre o menininho tinha sido muito proveitoso e que ela tinha compreendido que procurava permanecer sempre como a pessoa principal na vida de alguém, que realmente não conseguia entender por que precisava acreditar que devia ser a pessoa mais importante para seu namorado ou para qualquer outro e que, se não fosse assim, então o relacionamento não dava certo. Dissemos, então, que seu ensejo de sempre ter um rei para seu reino fazia-nos pensar que havia uma tentativa de proteção contra sua solidão, que ela devia achar terrível, que devia a assustar demais.

Gostaríamos, nesse momento, de fazer uma consideração que nos parece central: a de que pode ser uma expressão de atuação o fato de que o paciente passe a demandar do seu analista que se torne aquele que poderá minimizar seu sentimento de orfandade. Para isso, ele cria, por meio de transferência, uma situação na qual faz de seu analista um novo pai ou

\footnotetext{
${ }^{22}$ Esse menininho, na época com dois anos e seis meses, tinha uma grande ligação com seu pai e procurava sempre saber o motivo da sua ausência quando ele não se encontrava em casa. Era frequente o fato de seu pai chegar em casa e ele perguntar: "Papai, por que você trabalha muito?" O pai então respondia que tinha que trabalhar para ganhar dinheiro, para lhe comprar coisas, porque gostava de trabalhar etc., mas, para cada resposta dada por seu pai, o menininho, não satisfeito, continuava insistentemente a fazer a mesma pergunta.
} 
alguém que poderá retirar de si mesmo o encargo sobre tal sentimento. $\mathrm{O}$ analista, por sua vez, pode atuar tal transferência e teorizar que o paciente poderá, regredindo, tornar-se um novo pai ou uma nova mãe para ele. Além de mentiroso, esse movimento parece ser alienante e defensivo, demonstrando que há um processo de conluio da dupla, que se abstém de sentir a visitação do Real, além de criar dependência de difícil resolução e que não leva a nada mais do que fazer o paciente acreditar que sua condição originária deve ser algo tão terrível que deveria ser realmente encoberto por uma nova paternidade.

A interpretação do ataque ao bom objeto pode seguir nessa direção. A partir de algumas considerações de Safra (2007) sobre o tema, parece-nos que o trabalho com a questão da solidão ou da orfandade apenas poderá ser feito por uma psicanálise que busque, realisticamente, o testemunho da ausência e não uma tentativa de substituição da ausência por uma nova paternidade. Ampliando aquilo que o paciente já sabe sobre sua real condição existencial, pensamos que as transformações dos conflitos podem ser decorrentes da capacidade criada durante a análise de o paciente ter experiências consigo mesmo dentro das sessões, entre elas, a experiência de ser só e órfão, e isso ocorre inicialmente na presença do analista; tal como a solidão da criança, para ser possível como solidão, precisa ser uma solidão com mais alguém presente (Winnicott, 1958/1982a), que poderá dar a sustentação necessária para que a apreensão dessa realidade psíquica dolorosa torne-se possível.

Bion também considerava assim. Em Elementos de psicanálise, no mesmo ano em que Winnicott (1958/1982a) discutia sobre a solidão primordial do homem, Bion (1963/2004b) considerou que o paciente não poderia ser privado, de modo algum, do senso de isolamento que lhe é característico durante a análise; que as circunstâncias reais que o levaram à análise constituiriam algo que não poderia ser compartilhado com ninguém; e também que o paciente só consegue distanciamento (Detachment), tão importante para o trabalho analítico, à custa de dolorosos sentimentos de insegurança, solidão e abandono. 
Voltando mais uma vez à nossa paciente: ela continua em atendimento e luta contra sentimentos dolorosos de insegurança, solidão, orfandade e abandono; portanto, anseia pela vinda de um novo rei. No entanto, essa luta tem parecido ser contra aquilo que mais parece evidente de sua própria condição existencial; ou, ainda mais: uma luta para que aquilo que se desvela como solidão originária seja esquecido por meio do rei posto.

Em determinada sessão em que a paciente encontrava-se triste e vestida inteiramente de preto, ela contou que havia terminado seu relacionamento com um namorado e que estava muito triste por isso; disse não entender bem o motivo, mas o certo era que o relacionamento não estava bom já fazia bastante tempo. Ela se lembrou de que havia tentado constituir uma relação de maior proximidade, mas, à medida que ela se aproximava dele, ele parecia se distanciar. Essa distância foi sendo percebida como cada vez mais dolorosa, de modo que ela passou a sentir que, entre um encontro e outro, certo "fio" rompia-se, de modo que se sentia muito sozinha e muito instável. Passou a falar sobre o amor e em como sentia que faltava amor em sua relação.

Durante essa sessão, lembramo-nos da figura de Ulisses, que estava permanentemente em viagem, distante de sua casa e em trânsito; permanecia em algum lugar, em uma ilha, e depois ia novamente embora. Essa lembrança ocorreu após a paciente ter dito que gostaria de poder viajar, de ganhar dinheiro e viajar; contamos a ela sobre Ulisses. Parecia que ela estava novamente no meio do mar, que havia deixado alguma ilha na qual havia passado bem durante uma temporada, mas estava novamente no mar, indo para mar aberto. Pensamos que isso já havia acontecido muitas vezes em sua história: navegar em mar aberto, na instabilidade do mar revolto; parecia que o barco, ou seja, ela mesma, era capaz de manter-se resistente às intempéries do mar. A paciente respondeu que havia uma diferença entre aquilo que ela queria e o que acontecia realmente: ela queria uma ilha com céu azulado, mas o barco ia para o mar. 
O barco, que resiste às tormentas, permanece às vezes à deriva, dissemos; mas a paciente disse: “Olha, Ricardo, eu acho que não. Ele volta sempre para o mesmo lugar..."

Sua colocação deixou-nos atordoado; ficamos durante um período sem saber exatamente o que falar. Sentimos, então, que essa paciente, que fazia um esforço por mostrar sua aparente fragilidade e instabilidade, voltava sempre para o ponto inicial de uma nova jornada no meio do mar aberto, de um mar aberto que pode ser sempre cheio de tempestades e de instabilidade, mas, acima de tudo, parece que havia nela essa constante ida para o mesmo lugar, um lugar que devolvia a ela a instabilidade de seu ser. Nessa instabilidade, ela podia experimentar sempre sua solidão e, principalmente, sentir que seu barco era resistente o suficiente para passar por outras tempestades, como por decapitações dos reis. Lembramo-nos de que aquilo que havia trazido a paciente para os atendimentos, há muitos anos, tinha sido um câncer extremamente agressivo, que havia feito com que sentisse que sua vida estava por um fio; um fio que poderia se romper a qualquer momento. Mas esse foi um fio que não se rompeu de uma teia em que novas ilusões foram tecidas em cima do nada e narrativas de reis decapitados, narrativas de instabilidade perpétua foram contadas.

As sessões seguintes testemunharam lembranças de sua infância: chorando sozinha em seu quarto quando seus pais brigavam; mudando de escola repetidas vezes por conta do trabalho de seu pai, de modo que não fazia amigos; uma mãe que se mantinha afetivamente distante dela e que não conhecia seus sentimentos; um primeiro casamento constituído com alguém que não amava; uma gravidez perdida; violência. Essas lembranças eram recordações de que o barco voltava sempre para o mesmo lugar, para o lugar da instabilidade, da solidão e do desejo de encontrar um porto-pai-rei - sempre e inevitavelmente ausente - para poder lançar âncoras. 


\subsection{Cena Primária e a Realidade Perdida}

Nós somos os homens ocos

Os homens empalhados

Uns nos outros amparados

O elmo cheio de nada. Ai de nós!

Nossas vozes dessecadas,

Quando juntos sussurramos,

São quietas e inexpressas

Como o vento na relva seca

Ou pés de ratos sobre cacos

Em nossa adega evaporada

T. S. Eliot

Nesta segunda narrativa clínica, que apresentaremos agora, iremos acompanhar a história de uma impossibilidade de ser vislumbrado o aparecimento negativo do Real, como uma visitação, por meio da intolerância da cena primária, ou melhor, da intolerância do surgimento daquilo que promove a imaginação do que acontece no "quarto ao lado": o ponto ausente do Real.

\subsubsection{Quem Sonhará esse Sonho?}

Comumente é dada a denominação ao teatro de Samuel Beckett de "teatro do absurdo". Estranha denominação. Essa estranheza decorre do fato de que, em uma de suas peças mais conhecidas, Esperando Godot (Beckett, 1976), há a corajosa descrição não de um absurdo, mas de uma realidade. Trata-se, por isso, de uma realidade que se mostra por meio de uma representação, por meio de uma peça de teatro, mas a nossa aproximação dessa realidade, tal como de determinada realidade psíquica, não ocorreu paulatinamente ou por uma procura deliberada. Foi, antes de tudo, uma surpresa ao observar tal correspondência, nascida talvez da necessidade de pensar sobre uma realidade que ali estava e que, como questão, não se 
desenvolvia facilmente, embora estivesse presente e atuante nas sessões. Tal realidade, que não poderia ser confundida com a aparência da realidade, permaneceu como um horizonte diante do qual pudemos caminhar, como um horizonte insaturado, que foi nos oferecendo múltiplas possibilidades de compreensão. Pela peça, pudemos representar de modo extremamente expressivo a experiência que tínhamos presente nas sessões. Assim, foi uma surpresa encontrarmos tal correspondência; e isso também gerou profundo mal-estar, quando percebemos que parecia termos nos tornado uma espécie de personagem nas sessões, que corresponderia a um dos protagonistas da história.

Essa peça narra a "trajetória" de dois homens - Vladimir e Estragon - que, todos os dias, num local, à beira de uma estrada deserta, junto a uma árvore solitária, sem colorido, sem vida, esperam Godot. Falam entre si, mas falam em um ambiente árido, vazio e miserável; falam sem parar, mesmo que nada tenham a dizer. Esperam o senhor Godot (que não se sabe quem é) e, nessa espera, transmitem ao leitor (ou ao espectador) fundamentalmente a irrealidade da realidade falada por eles e, quiçá, pronunciam também uma denúncia sobre esse sentimento de irrealidade. Os jogos, as brincadeiras e as situações que eles vivem são apenas tentativas de criar modos de ocupação e, ao mesmo tempo, desvelam a irrealidade dessas mesmas atividades e uma profunda ausência de sentido nas coisas e no contato com a própria mente.

Nessa peça de teatro, somos convidados, ao acompanhá-la, a sentir, como espectadores, uma angústia interminável de seus protagonistas, que esperam a "salvação" que a eventual chegada do senhor Godot poderá trazer. Trata-se, acima de tudo, da observação de uma situação fantasmática: dois homens vivem acompanhados do vazio e do tédio, com um sentimento de profunda ausência de sentido na vida, fazendo dela uma espécie de "teatro do absurdo"; no entanto, parece que aquele ambiente e aquelas emoções a partir das quais a peça desenvolve-se não são de forma alguma um absurdo, mas a expressão de emoções que poderíamos explicitar como relativas à perda do sentimento de realidade. Certamente, a promessa de uma vinda do 
senhor Godot, tal como é descrita na peça, pode trazer consigo não apenas a possibilidade de uma ruptura na irrealidade e, portanto, a "salvação" almejada pelos protagonistas, como também o sentido mesmo da espera e da peça, que se desenrola sob esse mote.

É, no entanto, curioso que esse sentimento de irrealidade seja expresso tão bem desse modo, por meio de uma peça de teatro. Somos convidados a permanecer como espectadores de dois homens que não conseguem gerar coisa alguma, que estão profundamente impossibilitados de produzir ou de criar algo e, por isso mesmo, permanecem envolvidos por um ambiente incrivelmente árido e infértil. A sensação gerada no espectador (e também no leitor da peça) é de que isso é intolerável, que ambos não poderão aguentar mais tamanha falta de sentido e tamanha aridez. A ausência de sentido, porém, não apenas não é modificada por eles, como é o desencadeante da tentativa de suicídio no final da peça (que, embora não se concretize, demonstra ainda o ridículo de qualquer ação produzida pelos protagonistas, até mesmo essa, diante da perda do sentimento de realidade). Por meio da peça, somos convidados a observar que essa dupla - incapaz de criar, de fazer gestos produtivos ou imaginativos - também é incapaz de criar a intimidade que a proximidade física propiciaria e, embora não criem nenhuma intimidade, não conseguem se deixar para permanecerem sozinhos, cada qual com sua vida e direção. Claro que podemos entender, na medida em que a peça avança, que esse clima de aridez e de vazio é a expressão do universo imaginário ou do clima emocional dos protagonistas e, por isso, o ambiente é o reflexo de determinada vida mental.

Bion (1950/1994e), no seu trabalho para ingresso na Sociedade Britânica de Psicanálise, intitulado $O$ gêmeo imaginário, descreveu um de seus pacientes como alguém absolutamente arredio a qualquer tipo de contato emocional. Suas interpretações, quando procuravam trazer à luz alguma expressão do conflito do paciente ou alguma compreensão sobre seu mundo mental, faziam com que o paciente tornasse-se arredio, distante, sem querer ser "tocado" por elas. Como o próprio autor descreveu, o início do atendimento foi especialmente difícil, pois 
até então seu tom de voz era uniformemente destituído de emoção, e conseqüentemente o que ele dizia era difícil de interpretar, pois quase sempre, tinha um caráter ambíguo que admitia diferentes significados, se visto ora com um determinado conteúdo emocional, ora com um outro, diverso. (Bion, 1950/1994e, p. 13).

Mas isso ocorria de certa forma pelo fato de que "o quanto a ansiedade gerada pelas interpretações feitas antes do surgimento do gêmeo provinha não só do conteúdo das associações mas do simples fato de eu estar lhe dirigindo a atenção para seus processos intrapsíquicos" (Bion, 1950/1994e, p. 18), ou seja, Vladimir e Estragon, assim como o paciente de Bion, estavam em uma situação emocional em que não permitiam fazer uma aproximação de seu mundo mental.

O senhor Godot poderia ser inicialmente compreendido como uma salvação, porque traria algum sentido, alguma possibilidade de modificação em uma emoção que permanece profundamente árida e estéril; seria, portanto, algo que "tocaria" Vladimir e Estragon. No entanto, essa "salvação" parece ser apenas um engano, se pensarmos nessa descrição feita por Bion (1950/1994e), ou seja, se o senhor Godot viesse - e, na peça, ele é sempre compreendido como aquele que virá e nunca como aquele pelo qual se irá em busca ou em direção -, ele seria parte do ermo, do estéril e do árido. Godot, porém, permanece como um outro opositivo, que deve permanecer no "palco ao lado" e que deve ter aquilo que ambos não têm, ou seja, realidade. Por isso, somos levados, diante do isolamento da peça, a devanear justamente com o senhor Godot; somos levados a devanear sobre quem pode ser ele, sobre o que ele faz, sobre o que ele tem, aonde mora, com quem vive, com quem se relaciona etc., ou seja, nossa atenção, como num passe de mágica, dirige-se para além da peça, para o palco ao lado, que, embora não exista, passa a ser imaginado como uma referência que fundamenta a peça e dá sentido a ela, mesmo que nós não pensemos conscientemente a respeito disso, como uma cena imaginada de um palco invisível. 
Assim, o senhor Godot é um opositivo, um contrário, por meio do qual a peça passa a ser não só tolerada e aliviada, mas tornada possível, pois ela tem algo que, embora não esteja presente, oferece a nós um universo de imaginação, de outras possibilidades, para o qual os protagonistas dirigem-se constantemente. Esse outro palco, na verdade, é o palco onde estariam ocorrendo as coisas, onde estariam ocorrendo as coisas reais. Trata-se de um universo oposto ao que eles estão em relação e diante do qual os protagonistas ficaram apartados, profundamente rompidos, de modo que parecem não poder sonhar viver essa cena imaginária desse outro palco.

Somos convidados, como espectadores, a observar e permanecer observando atentos e comovidos. Parece que essa comoção encontra-se no fato de que mesmo Godot não é um estímulo para que os protagonistas possam imaginar essa outra peça que ocorre em um palco ao lado. Eles não podem imaginar Godot e isso ser o espaço diante do qual se criaria alguma forma de criação da parte deles; tanto Estragon quanto Vladimir não podem se remeter a essa outra peça, porque essa seria uma imaginação terrível: seria a imaginação de que ocorre algo imaginariamente na "peça ao lado" e, junto a isso, a percepção da existência de uma profunda separação entre essa peça e eles, ou do sentimento de terem sido abandonados na experiência de aridez por alguém que se anseia e de quem se espera tanto.

Poderíamos dizer, ainda, que em Esperando Godot (Beckett, 1976) não há apenas a perda da imaginação, mas fundamentalmente a perda da capacidade de sonhar, e, se compreendemos que o senhor Godot é potencialmente o sonho ausente, então também pensamos que ele se encontra, como promessa de salvação, em outro lugar. Assim, talvez seja importante acrescentarmos à peça o espectador, pois, pelo efeito que essa peça tem nele, que consegue sonhar Godot, podemos dizer que a capacidade de sonhar dos protagonistas está nos espectadores, naqueles que observam a cena distanciados dela, ou seja, são os outros que sonham o sonho impossível dos protagonistas, impossibilitados desse sonhar. 
Britton (2003), em seu artigo O outro quarto e o espaço poético, transcreve uma passagem de Paraíso perdido, de Milton, que é extremamente mobilizadora. Trata-se de uma cena na qual Satã observa, no Éden, o idílio dos nossos míticos ancestrais, Adão e Eva, e, após ficar cheio de inveja e de profundo ódio, professa sua maldição sobre ambos, dizendo:

[...] Vivam enquanto podem,

Ainda casal feliz: aproveitem até que eu volte,

Prazeres passageiros, pois dores intermináveis hão de vir. (Milton, citado por Britton, 2003, p. 175).

Trata-se de um espectador que, deslocado da cena de êxtase, sem poder experimentá-la e tomado da inveja mais profunda, procura destruir aquilo que há de bom naquilo que está sendo visto, pois, do ponto de vista de Satã, seria injusto ser ele condenado a ser lançado ao inferno, onde não há alegria, bondade ou amor, e ser apenas tomado por um intenso desejo que é insaciável e desesperado, enquanto os outros se extasiam na plenitude. Essa é a visão de um idílio que lhe é impossível, pois ele lhe foi retirado, e do qual, por isso mesmo, está apartado. O ódio por esse afastamento vem da impossibilidade de recuperação do idílio, que é fundamentalmente considerado - até por Satã - desejável e bom. Satã sente-se invejoso porque não vive tal idílio e, fundamentalmente, sente-se só. Em Esperando Godot (Beckett, 1976), há, no entanto, a esperança da recuperação de um contato, pelo menos se considerarmos que Godot é uma pura possibilidade de salvação. Talvez, nesse sentido, não possamos dizer que nessa peça há uma total falta de sentido, pois o sentido encontra-se na passagem para esse outro palco, do qual poderão, por fim, participar.

Entretanto, enquanto o outro palco, na cena de Paraíso perdido (Milton, citado por Britton, 2003), é visto, vislumbrado e invejado, a cena de Esperando Godot (Beckett, 1976) pode ser somente imaginada pelo espectador. O que há em comum entre ambas é o fato de que há sempre uma cena posta, como uma cena visível ou invisível, e o protagonista permanece 
distante, afastado dela ou sentindo estar abandonado, o que faz com que tudo pareça vazio, um inferno constituído de aridez. Se pudéssemos caracterizar o sofrimento de seus personagens, diríamos: trata-se da angústia de se estar só, na impossibilidade de aceitação da solidão originária que a triangulação edípica ressalta e explicita; seria esse o sofrimento.

Em Esperando Godot (Beckett, 1976), os protagonistas esperam em vão a chegada do senhor Godot. Mas, a sua chegada, o que poderá trazer? Não seria o mesmo que trazer Adão e Eva para a cena de Satã no inferno, junto a ele? Ou seja, a cena que ocorre no outro palco não precisaria ser preservada para que exista a esperança de que o sentimento de abandono não prevaleça e para que se possa sonhar com essa cena - e por meio dela seja possível o sonhar -, tal como fazem os espectadores do outro palco invisível de Esperando Godot (Beckett, 1976)? Caso contrário, a promessa de salvação tornar-se-ia uma esperança em vão, que não proporcionaria imaginação e ilusão, ou, ainda, poderíamos dizer que essa outra cena, tal qual a cena primária (Freud, 1918/2006q), não seria mantida como uma cena possível, pois os protagonistas deixariam de participar dela. Ou seja, a possibilidade de sonhar essa cena não se constituiria, pois os processos invejosos atuariam de forma a destruir aquilo que era observado e qualificado como bom, como um anseio, tal como Satã reconhece o êxtase de Adão e Eva.

Essa cena primária, expressão de uma posição em que há triangulação edípica, ocorre com um observador de uma cena visível ou invisível, com um protagonista que se sente, de alguma forma, afastado dessa cena e, portanto, impossibilitado de experimentar aquilo que observa ou imagina que ocorre na cena "observada". Podemos compreender, com isso, que as fantasias de um coito sádico e violento, descritas nas fantasias dos neuróticos e observadas por Freud (1918/2006q) nas fantasias sobre a cena primária, seriam expressões de uma atitude agressiva do observador para com essa cena, da qual é, inevitavelmente, colocado de lado; assim, o sentimento de exclusão e de solidão decorrente da exclusão tornar-se-ia o fundamento da agressão invejosa. 
Vladimir e Estragon permanecem, a maior parte da peça, cegos ou em uma situação emocional em que parecem estar dormindo; ${ }^{23}$ são cegos porque não podem "ver" a desolação do nada, o desterro, a orfandade e a solidão como originários de sua condição humana. Eles personificam, em certa medida, a tentativa de cegar-se da cena primária e, com isso, a destruição de toda a realidade, inclusive destruindo a si mesmos no processo, mas fazem isso, paradoxalmente, por não aceitarem a própria condição originária. ${ }^{24}$ Winicott (1958/1982a), ao discutir sobre a capacidade para estar só, diz que ela depende, em parte, da capacidade do estabelecimento de relações triádicas; portanto, a capacidade individual de estar só “depende de sua capacidade de lidar com os sentimentos gerados pela cena primária.” (p. 33). O autor completa essa afirmação dizendo que a criança, ao sentir como excitante uma relação percebida ou imaginada acontecendo entre os pais, aceita essa cena e, embora sinta raiva disso, pode usar essa raiva na masturbação, na qual: "a responsabilidade inteira pela fantasia consciente e inconsciente é aceita pela criança, que é a terceira pessoa numa relação triádica ou triangular.” (p. 33).

Na peça, em certo momento, os protagonistas falam das suas esperanças, uma vez que: “também para mim alguém está olhando, também sobre mim alguém estará dizendo: Ele está dormindo, ele não sabe nada, deixe-o dormir...” (Beckett, 1976, p. 178). Trata-se de uma fala que toca profundamente o espectador ou leitor da peça; parece que, nesse momento, alguma lucidez foi novamente possível, como em alguns momentos acontece durante a peça.

Essa fala conduz-nos justamente àquilo que foi desenvolvido por Winnicott (1958/1982a) como o fato de que essa possibilidade de estar só depende fundamentalmente de se ter a experiência da presença de um outro, que, a princípio, olha, observa e para quem o

\footnotetext{
${ }^{23}$ Muitas são as passagens da peça em que essa temática aparece. Quase no final, Estragon pergunta para Vladimir ou para ele mesmo: “- Eu dormi muito tempo?” E Vladimir responde: "Não sei.” (Beckett, 1976, p. 182). No texto escrito pelo autor, não há uma indicação de que Estragon tenha dormido; parece, portanto, que ele apenas estive ausente, mas de corpo presente.

${ }^{24}$ Discutiremos, ao longo deste trabalho, pormenorizadamente aquilo que compreendemos como a condição originária do ser humano. Para tanto, designamos certas condições negativas fundamentais como visitações do Real: solidão originária, desterro, orfandade e o nada, as quais serão referenciadas neste trabalho como a quaternidade negativa do Real.
} 
observado retorna de vez em quando o olhar, certificando-se de que está acompanhado, para poder depois prescindir do observador. Nas palavras do referido autor, "essa experiência é a de ficar só, como lactente ou como criança pequena, na presença da mãe. Assim, a base da capacidade de ficar só é um paradoxo; é a capacidade de ficar só quando mais alguém está presente.” (p. 32). Contudo, nesse caso, diferentemente de Vladimir e Estragon, pode-se prescindir do observador, porque há o observador incluído em si mesmo, um outro que olha por nós de dentro de nós e que possibilita o contato com a realidade, pois é um outro sonhador, que sonha nossos sonhos - triangulares - impossíveis; um sonhador que, em rêverie, sonha por meio de nós.

Ogden (2010) discute essa questão de um modo muito interessante, em seu artigo Esta arte da psicanálise: sonhando sonhos não sonhados e choros interrompidos, no qual formula que o paciente consulta o analista pelo fato de que é ou tornou-se incapaz de sonhar. Como é incapaz de sonhar sua experiência emocional, não consegue mudar, crescer e se desenvolver; por isso, a tarefa da psicanálise é a de ser um experimento cujo intuito é gerar condições para que o paciente seja mais capaz de sonhar seus sonhos não sonhados e interrompidos. Em sua concepção, os sonhos sonhados pelo paciente e pelo analista "são, ao mesmo tempo, seus próprios sonhos (e rêveries) e os de um terceiro sujeito que é e não é paciente ou analista.” (p. 28).

$\mathrm{Na}$ peça, esse sonhador que sonha os sonhos impossíveis dos protagonistas é o espectador. É o espectador, essa figura absolutamente geral e que assume um caráter de universalidade, de gênero humano, que pode sonhar e, nesse sonho, realiza aquela peça imaginária que está lá para ser imaginada. Poderíamos afirmar, como Parente (2011), que "todo e qualquer objeto é uma obra potencial e a apreciação estética só depende do olhar” (p. 255), assim é o espectador que realiza a obra; por isso, há um clamor pela capacidade imaginativa do espectador, uma vez que ela está impossibilitada nos protagonistas. Essa possibilidade de 
rêverie, de sonhar um sonho impossível, é o clamor dirigido para a humanidade como um todo, como uma tentativa de explicitação e de denúncia do sentimento de irrealidade, como uma questão que, como um grito, está no ar. "O ar está cheio de nossos gritos” (Beckett, 1976, p. 178), exclama Vladimir, e esses gritos, como pensamentos não pensados, como aquilo que urge e atordoa, fazem com que todos permaneçam dormindo, cegos, mas andando por aí, como aquele personagem infantil, de antigos desenhos animados, o Mr. Magoo.

Em diversos de seus textos, Bion (1962/1994c, 1965/2004a, 1970/1991a) procurou explicitar a tese de que os pensamentos dependem de um pensador que os pense, pois sua realidade não está subordinada à existência deste. Assim, ele procurou inverter a lógica comumente aceita de que os pensamentos seriam o produto de uma atividade da mente humana, da capacidade de pensar. Para o autor, trata-se exatamente do oposto, ou seja, de que o pensar pode se desenvolver a partir dos pensamentos, que estão aí para poderem ser pensados, à espera de um pensador que os pense; o aparelho mental corresponde a um aparelho para pensar os pensamentos. Desse modo, Bion (1975/1989) pode dizer: “eu lanço mão de uma premonição de que podem haver pensamentos sem pensador" (p. 182), ou seja, pensamentos que ainda não puderam ser pensados, mas que, embora não sejam pensados, são reais. Nesse sentido, aquele personagem infantil talvez represente a cegueira daquele que não pode pensar e, assim, é incapaz de perceber o mundo e ter experiências emocionais.

A realidade impensada de Esperando Godot (Beckett, 1976) é a explicitação do inferno com o outro que não sonha por nós, com um outro representado por Godot, com sua frieza, distância e inacessibilidade. Vladimir e Estragon não têm contato com ele, nem imaginariamente nem de modo real; o contato com Godot é intermediado por um menino (ou dois - eles não sabem se é o mesmo menino e o menino também não), que traz um recado gélido, recado de alguém que deveria se encontrar apenas porque tem um compromisso. 
Pensamos que Godot representa, desse modo, a impossibilidade de participação na vida mental do outro ou, como nos diz Safra (2005),

\begin{abstract}
Ocupar um lugar no mundo é ocupar um lugar na vida de outro. Somente a partir dessa experiência é que o olhar poderá direcionar-se para o mundo com curiosidade e desejo. A tridimensionalidade poderá, então, surgir no horizonte psíquico da criança. Isto significa que, de posse de um corpo que foi significado pela presença do outro, a criança dispõe de vida imaginativa, que lhe possibilita ocupar o vazio da ausência do outro com sua capacidade de sonhar. (p. 84-85).
\end{abstract}

Podemos compreender que o sentimento de irrealidade, a partir disso, decorre da impossibilidade de sonhar e, principalmente, da impossibilidade do sonho daqueles que poderiam sonhar por nós! Pois, apenas ao se sentir inconscientemente participando do sonho de alguém é que aquele que não sonha pode sonhar e esse sonho é basicamente a inclusão desse outro em nosso mundo mental. O sentimento de ser real é fundado, portanto, na experiência de que aquilo com o que se sonha é compartilhado, o que produz sentimentos de pertencimento e de participação na vida coletiva e na língua da família e da comunidade. Podemos afirmar, assim, que Vladimir e Estragon não suportam o sentimento de solidão porque ele não foi transformado em vida imaginativa, em vida de sonho, e essa transformação não foi possibilitada porque aqueles que poderiam sonhar por eles não puderam sonhar e, assim, incluí-los em seu mundo mental. Poderíamos dizer que a solidão é uma condição originária do ser humano e a possibilidade de apreensão do sentimento de solidão só é possível quando se dispõe de possibilidade de imaginar um "outro palco" ou de sonhar sobre uma relação triangular da qual se é observador ou, de algum modo, de poder ansiar um outro. A solidão originária pode, no entanto, converter-se em experiência de horror diante da vida, um horror ante a experiência de 
não participação na vida do outro, tendo a própria vida como uma experiência nadificante, da qual nada vem e que, na filosofia escolástica, foi designada pela expressão 'ex nihil nihil fit' ${ }^{25}$

Alguns pacientes parecem fazer da sua experiência de solidão uma experiência nadificante, de exclusão e de impossibilidade de relacionamentos com as pessoas. Carlos parece ser um desses pacientes. Poderíamos continuar chamando-o de Vladimir ou de Estragon, conquanto nos incluísse como o outro da dupla, mas preferimos chamá-lo Carlos, para continuar mostrando, como Bion (1975/1989), que um nome fictício pode ser muito mais real do que um nome ou uma pessoa real. ${ }^{26}$

Carlos veio nos procurar porque queria alguém que pudesse conversar com seu namorado; vinha procurando análise para um outro. Dizia que ele estava precisando muito conversar com alguém, que estava muito sozinho e parecia estar sofrendo muito. Na verdade, antes de nos procurar, havia tido algumas sessões com uma colega nossa, que o tinha recebido, mas que não poderia desenvolver um trabalho com ele ou com seu companheiro, porque estava se mudando para outro país. Quando Carlos veio conversar conosco, no entanto, essa temática permaneceu, embora ele dissesse que seu companheiro não queria fazer nenhum tipo de processo psicanalítico. Parecia ser contraditório.

$\mathrm{Na}$ ocasião, chamamos a sua atenção para o fato de que quem procurava por uma conversa era ele e não seu companheiro e que, por isso, parecia que era ele que queria conversar. Carlos aceitou nosso comentário, porém nos pareceu que sua aceitação não fora uma concordância, mas certo submetimento. Passou a vir religiosamente às sessões, nunca faltava; no entanto, durante as sessões, nosso sentimento era sempre o mesmo: um desconforto que poderia ser expresso com a pergunta: o que Carlos está fazendo aqui? Quem deveria se tratar,

\footnotetext{
${ }^{25}$ Do nada, nada vem.

${ }^{26}$ Bion (1975/1989), em Uma memória do futuro, logo em seu Pró-Logo, diz que um personagem shakesperiano como Falstaff, nas formulações verbais de Shakespeare, "é mais 'real' do que incontáveis milhões de pessoas que são opacas, invisíveis, desvitalizadas, irreais, em cujos nascimentos e mortes - e, que pena! Até mesmo casamentos - somos obrigados a acreditar, já que sua existência é certificada e garantida pela certidão oficial." (p. 8). Trata-se de um pensamento que encontra eco também em Pirandello (1921/1981), que, em sua peça Seis personagens à procura de um autor, diz-nos: "É isso mesmo! Exatamente! Dar a vida a seres vivos, mais vivos do que aqueles que respiram e vestem roupas! Menos reais, talvez, porém mais verdadeiros. Somos da mesma opinião.” (p. 363).
} 
ele ou o seu outro? Parecia que Carlos não tinha a mais vaga ideia do que fazia nas sessões, ou seja, nem nós sabíamos o que ele fazia estando ali, nem ele sabia o que fazia estando ali. Enquanto essas dúvidas tornavam-se cada vez mais explícitas e perturbadoras para nós, ocorreu que, à semelhança de Grotstein (2003), percebemos existir uma diferença marcante entre um sujeito fenomênico, que dizia que tudo lhe estava bem, e um outro sujeito do inconsciente, desconhecido por nós e do qual nada era falado, ou melhor, nada era escutado por nós; um desconhecido que parecia também silencioso e ausente. Nesse momento do trabalho, a crença na existência desse ausente possibilitou-nos a continuidade do trabalho clínico. O "paciente fenômeno", de queixas imprecisas, parecia o avesso do analisando habitual: esse nosso paciente parecia que não deveria estar ali.

Ele não saber o que fazia quando estava ali decorre do fato de que o seu discurso era basicamente um discurso no qual não havia qualquer tipo de questão ou de queixa a partir do qual falasse, permanecendo com uma conversa que era, sem sombra de dúvida, de uma pessoa que não falava em nome próprio. Incrivelmente, passava todo o seu tempo descrevendo a vida dos outros, de modo que substituía a sua própria vida pelo "interesse" na vida alheia. Apesar disso, pudemos saber algumas coisas da sua vida pessoal, basicamente por meio de perguntas diretas. Ele era um rapaz alto, tipo esportista, homossexual, de uma família tradicional de uma cidade do interior de São Paulo e tinha como atividade profissional a administração de uma fazenda da família, que fazia com que ele fosse e voltasse do interior com frequência; parecia estar sempre apressado e em trânsito. Ao se deitar, não punha os pés no divã, permanecendo com uma das pernas para fora dele; parecia que estava sempre prestes a correr, prestes a se levantar. A sua conversa permanecia sempre relativamente animada, mais como uma conversa diante de alguém com quem se quer entreter. $\mathrm{O}$ entretenimento tornou-se o mote das suas idas às sessões e, por uma ou duas vezes, estivemos ao ponto de lhe dizer que não havia sentido em continuar as sessões daquela forma. Acabamos por não fazer isso, porque imaginamos que o 
paciente não iria compreender o sentido disso, simplesmente porque nos parecia que ele não sabia o significado de uma relação que não fosse feita para entretê-lo. Para nós, era extremamente custoso permanecer com alguém que basicamente não fazia análise como pensamos que deveria ser feita e diante do receio de entrar em algum tipo de conluio baseado em propósitos que não os analíticos.

Carlos permanecia se relacionando conosco, "compreendendo-nos" como alguém que permanecia, como ele, superficial nas relações e, em relação às coisas do mundo, passivo e acuado. Essas coisas referiam-se principalmente aos desejos das pessoas, desejos que ele tinha que cumprir. Sentia-se um engolidor de sapos; engolia muitos sapos, porém fazia uma cara de que engolir sapos era a própria vida, de modo que não achava que devia fazer alguma coisa sobre isso. Havia sempre um tom de certo ressentimento consentido, de uma aceitação conformista. Começamos a pensar que seu começo de análise havia sido um começo infeliz, que ele havia consentido em fazer análise por uma colocação que havíamos lhe feito. Em certa sessão, pudemos dizer isso para ele, mas não sentimos que fez um efeito muito significativo. Nessa ocasião, o paciente estava preocupado com seu companheiro, ou melhor, preocupado com seu outro que precisava de ajuda, mas preocupado como alguém que considera que tudo vai bem. Percebemos, agora, que podemos fazer uma analogia entre esse outro ausente e o próprio Godot, no sentido de que era alguém pelo qual chegou à análise, alguém de quem queria poder imaginar.

Assim, sua presença nas sessões caracterizava-se por parecer ser relatos de situações vividas por outras pessoas. Cada sessão era iniciada por meio de frases como: "Então, o que vai ser hoje?”, "Então, o que você manda?’, “O que nós vamos falar?” etc.; frases que solicitavam um script para ser seguido por nós e por ele, algo como o início de um bate-papo em que o interlocutor era "convidado" a expor o seu desejo. Posteriormente, essas perguntas passaram a ser antecedidas, quase sempre, por períodos de silêncio nos quais o paciente parecia permanecer 
em um estado meditabundo e de concentração. Com frequência, esses estados eram rompidos por um simples descruzar de pernas ou por um pequeno barulho de nossa parte; então, dispersando-se de seu estado, ele perguntava uma das frases comuns e rotineiras: "E então, o que vai ser hoje?", "O que você manda?" etc. Parecia que qualquer movimento nosso poderia ser intrusivo em relação àquele estado em que ele se encontrava. Lembramo-nos, em uma dessas ocasiões, de uma passagem de Winnicott (1963/1982b) sobre a comunicação e a falta de comunicação. A passagem é assim:

Ao se pensar na psicologia do misticismo, é comum se concentrar na compreensão da reclusão mística no sentido de um mundo pessoal interno de introjeções sofisticadas. Talvez não se tenha prestado atenção suficiente à reclusão mística a uma posição em que se pode comunicar secretamente com fenômenos e objetos subjetivos, a perda do contato com o mundo da realidade compartilhada sendo contrabalanceada por um ganho em termos de se sentir real. (Winnicott, 1963/1982b, p.169).

Embora esse estado "meditabundo" fosse frequentemente rompido e parecesse que não era extraído nada dele, permanecíamos em silêncio, interpretando também silenciosamente que ele queria se certificar de que era possível ter um contato mais delicado consigo mesmo sem que isso fosse perturbado. Ainda que não parecesse que se tratava de um contato com ideias e pensamentos propriamente ditos, parecia-nos que, nessas ocasiões, Carlos tinha uma espécie de sensação consigo mesmo, diante da possibilidade de permanecer calado em frente a alguém, sentindo-se mais real, e isso parecia fundamental, visto que Carlos também aparentava ter uma preocupação muito grande em relação àquilo que nós queríamos, de modo que parecia ser fundamental para ele estar sempre atento à nossa presença; com o silêncio, procurávamos não "retirá-lo" desse contato tão precário consigo mesmo. 


\subsubsection{Entretenimento e a Realidade Perdida}

Carlos tinha o hábito constante de visitar cinemas pornôs e de ter "relacionamentos" sexuais rápidos e anônimos com pessoas do sexo masculino. Dificilmente tinha interesse amoroso por alguém e gostava de poder ter relações sexuais rápidas e fortuitas, sempre com rapazes bem mais jovens do que ele, porém sem a presença de penetração; pareciam ser formas de masturbação que ocorriam solitariamente na presença de alguém que era descrito como uma parte de uma pessoa. De qualquer modo, não havia como não nos lembrarmos daquela passagem de Os irmãos Karamazov, de Dostoiévsky (1879/1970, p. 58), que diz:

Aquele que mente para si mesmo e escuta sua própria mentira vai ao ponto de não mais distinguir a verdade, nem em si, nem em torno de si; perde, pois o respeito de si e dos outros. Não respeitando ninguém, deixa de amar; e para se ocupar, e para se distrair, na ausência de amor, entrega-se às paixões e aos gozos grosseiros; chega até a bestialidade em seus vícios, e tudo isso provém da mentira contínua a si mesmo e aos outros.

As sessões, em face de certo impasse em relação à problemática da análise do sujeito do inconsciente, desse ausente, passaram a ficar recheadas de temas cada vez mais ligados ao entretenimento. Havia uma tentativa do paciente de se satisfazer, ter prazer durante as sessões, como se esse lugar tivesse uma função de entretenimento, com a qual ele se ocuparia em um tempo sem sentido. Muito embora os motivos reais de seu comparecimento às sessões ainda não estivessem problematizados de fato, passamos a focalizar os aspectos ligados às atividades masturbatórias do paciente dentro da sessão e como pareciam estar associadas a algum tipo de patologia narcísica, que excluía a alteridade; essas atividades aconteciam ou por meio de objetos que lhe entretinham - objetos descritos por ele - ou com a fantasia de dominar a sessão ao não nos deixar falar e ao dizer, procurando nossa confirmação, que falava muito na terapia e não escutava o suficiente. Além disso, passava inúmeras sessões queixando-se - apesar de a palavra 
'queixa' ser-lhe extremamente estranha, pois não se concebia como alguém que se queixava de algo - de que sua vida era repetitiva, sem sentido e de que tudo era igual, sem modificação. Assim, para cada início de sessão em que perguntava: “Como vai?”, respondia, após a nossa resposta, dizendo que com ele ia tudo bem, que sempre estava bem, que com ele sempre estava tudo bem...

No entanto, certa manhã, recebemos um telefonema dele pedindo uma consulta às pressas, pois tinha algo muito importante para falar; consentimos com isso e lhe oferecemos uma sessão cerca de duas horas mais tarde. No horário marcado, o paciente chegou com um papel nas mãos, dizendo que seu namorado tinha HIV, que ele havia feito um teste, o qual estava na mão dele, mas ele não tinha tido coragem de abrir sozinho. "Queria abrir aqui com você", ele disse. Ficamos muito apreensivos e sentimos, nessa hora, que não havíamos percebido que o paciente tinha, para ele, uma relação de confiança conosco, que representava uma segurança importante naquele momento. Ele abriu o envelope e leu em voz alta: "Negativo". Ele estava ainda muito nervoso e disse que ainda iria fazer outro teste; falou que sentia que seu namorado estava havia muito tempo distante dele, até que lhe contou que estava doente. Ele, então, foi fazer o teste em seguida, mas, durante a sessão, disse que realmente não tinha nenhuma possibilidade de ter contraído essa doença, pelo fato de que eles não tinham relações sexuais; eles eram um casal que não tinha relacionamento sexual, mas que se consideravam namorados ou casados havia mais de dez anos.

Essa "intocabilidade", que podíamos observar nas sessões e em seus relatos de acontecimentos com pessoas fora da sessão, era uma expressão emocional e corporal que havia certamente blindado o paciente desse contágio. Certo medo de contágio, de contato emocional, de ser tocado pelo outro, havia feito com que, nessa situação, a realidade e a realidade psíquica adquirissem uma única forma. Para ele, portanto, seria próprio que os relacionamentos acontecessem somente sob essa possibilidade: serem entretenimentos para que não lhe 
penetrassem. Assim, parecia que não havia, nas sessões com Carlos, um teatro do absurdo, mas um drama sobre o real sentimento de irrealidade da vida e das relações. Identificar a realidade da sua vida mental, uma realidade que continuamos considerando viva e que estava além da aparência sensorial das definições interpretadas por ele, tais como ser homossexual, "comedor de sapos" etc., foi um dos motes que nos orientaram em seguida, com a intenção fundamental de não atuar em conjunto com ele, em algum tipo de conluio compreensivo, com definições sobre alguém que, de fato, não se conhece, para podermos, portanto, compreender os profundos e significativos sentimentos que impediam sua mente de crescer e se desenvolver. Essa atitude pode ser um método de cegar-se artificialmente para poder apreender aquilo que ainda é desconhecido ou, como disse Bion (1974/1975):

Não temos meios para adivinhar o quê os saqueadores do túmulo [de $U r$ ] sentiram. Eu até acredito que devem ter sido homens de muita coragem para ousarem roubar os tesouros ocultos num lugar guardado por espíritos maus e perigosos. Do mesmo modo, em psicanálise; quando nos aproximamos do inconsciente - isto é, daquilo que não conhecemos - estamos certos de ser perturbados. Todo aquele que amanhã vai encontrar um paciente deveria, de algum modo, experimentar medo. Em cada consultório, deveria mais precisamente haver duas pessoas amedrontadas, o paciente e o psicanalista. Se não estão, então seria o caso de perguntar por que estão se incomodando em descobrir o que cada um já sabe. (p. 15-16).

Desse modo, procuramos seguir aquilo que foi indicado como uma regra a ser respeitada no exercício da psicanálise, publicada por Bion (1967/2000a), em Notas sobre memória e desejo, que se mostraria fundamental para este trabalho. Nesse artigo, ele formula, entre outras coisas, que

aquilo que é 'conhecido' sobre um paciente não tem a menor consequiência: ou é falso ou é irrelevante. Caso seja 'conhecido' pelo paciente e pelo analista, fica obsoleto. Se um deles 'conhece' algo, mas o outro não, está operando uma defesa, ou um elemento da categoria 2 da 
Grade. ${ }^{27} \mathrm{O}$ único ponto de importância, em qualquer sessão, é o desconhecido. O analista não deve permitir que nada o distraia de intuir o desconhecido. (Bion, 1967/2000a, p. 392-393).

Freud (1909/2006o) indicava que a abstenção da curiosidade é uma condição para que o paciente possa tomar o rumo que desejar em seu discurso nas sessões. As perguntas, em geral, indicariam sempre para o paciente uma resposta, que já estava embutida dentro da pergunta. Precisaríamos, assim, interrogar-nos sobre nossa capacidade ou incapacidade de tolerar paradoxos, contradições ou a falta de conhecimento, e cuidar para que as "interpretações" não signifiquem uma tentativa de acabar com o problema, ao invés de ajudarem a mirar a realidade da qual falam, seu "O”, desconhecido, recolhido e necessariamente ausente.

A disciplina de banimento da memória e do desejo apenas tornou-se possível quando as sessões passaram a ter um desenvolvimento nelas mesmas, ou seja, quando foi possível compreender que aquele paciente que entra na sessão não é o mesmo que lá esteve na sessão passada. Além disso, a memória e o desejo, como formas de dar opacidade para a capacidade de intuir a realidade da sessão ou como formas associadas de esquecer o Real, dão uma história e um futuro para as sessões e para o paciente, algo que está absolutamente condicionado àqueles aspectos que são conhecidos e, portanto, saturados da mente, que está impossibilitada de tolerar o desconhecido e, também, o desagradável. Podemos dizer que, com isso, foi possível ir sonhando a sessão à medida que ela acontecia. Sem o arcabouço da memória, os acontecimentos de cada sessão tomaram uma tonalidade emocional que se assemelhou a uma experiência de sonho, mas esse sonho apenas foi possível acontecer pelo distanciamento necessário, que produziu o desagradável, na medida em que não permanecemos um Vladimir para um Estragon, ou um personagem indistinto do outro, podendo obter distanciamento "a custa de dolorosos sentimentos de solidão e abandono, experimentados pela herança mental primitiva a partir da qual se efetuou o distanciamento.” (Bion, 1963/2004b, p. 30-31).

\footnotetext{
${ }^{27}$ Elementos enganosos ou falsos.
} 
Nesse momento do tratamento de Carlos, pudemos, portanto, pela primeira vez apreender a experiência de que seu entretenimento era também uma explicitação da falta de sentido das relações humanas. Essa apreensão ocorreu quando pudemos nos conceber como um Vladimir para um Estragon; foi uma apreensão difícil e dolorosa. Diante desse sonho de irrealidade, pudemos compreender como permanecíamos com os aspectos criativos e imaginativos de nossa personalidade afastados da "cena analítica" e, como era de se esperar, Carlos passou a relatar que sua relação com amigos e familiares havia diminuído bastante. Ele e seu companheiro não tinham mais interesse em estar com ninguém; guardavam o segredo da doença e permaneciam alheios a qualquer tipo de contato com alguém que pudesse lhes "tocar" emocionalmente.

Carlos continuou vindo às sessões e fazendo um exercício de "intocabilidade"; tornou-se alheio a tudo o que existia à sua volta. Inúmeras formas de tentar alcançar sua realidade mental foram fracassadas e esse fracasso não se devia ao fato de que era impossível acessar a angústia do paciente, mas sim ao fato de que sempre que falávamos sobre algo que estava acontecendo na sessão com ele, o paciente, após parecer compreender algo, rejeitava sua compreensão e alguma possibilidade de progresso, muito embora sempre mantivesse seu caráter afável e cordial. No entanto, sentíamos que ele parecia se importar em vir às sessões, em que pudéssemos acompanhá-lo e que ele pudesse sentir que alguém - no caso, o analista permanecia atento a ele, mesmo quando ele se mostrava pronto para se levantar. Parecia alguém que não podia experimentar a solidão, basicamente porque a solidão parecia ser sua inexorável sombra, sua inexorável condição da qual se esquivava, pelo sofrimento que essa condição poderia lhe trazer.

Carlos parecia preocupado com a eventual perda de seu companheiro, que passou a ter sérios problemas de saúde; demonstrava preocupação com ele, ainda mais quando seu companheiro não mostrava disposição em se cuidar. Nesse período, entre uma e outra melhora 
de saúde de seu companheiro, Carlos permanecia espantado pelo fato de que o companheiro não lhe parecia ter qualquer noção sobre a realidade objetiva e agia apenas procurando realizar seus desejos, gastando enormes somas em presentes para parentes com quem não mantinha contato. O paciente parecia sentir que isso era um preço a pagar, um "sapo" a mais para engolir. As sessões coloriram-se com uma tonalidade estranha, com alguém que vinha perguntar "o que vai ser hoje", como alguém que se oferece para o desejo do outro, como um modo de poder confirmar que o outro permaneceria com ele, incapaz de sonhar o "outro palco" da realidade.

Depois de alguns meses, o paciente passou a acentuar ainda mais uma tendência de isolamento, dizendo que já não havia mais nenhum amigo por perto e que os familiares haviam sido afastados, uma vez que queria se certificar que ninguém saberia do estado de saúde do seu companheiro. No entanto, quando se sentia só, passava a achar que eram todos ingratos e entranhava-se ainda mais em uma relação cuja função parecia ser a de manter ele e seu companheiro com um sentimento de que a irrealidade era realmente real. Nesse momento doloroso, começamos a sentir, de modo angustiado, a impossibilidade de pressentir a solidão pela incapacidade de tolerância da cena primária, ou melhor, pela imaginação que essa cena produziria.

Carlos descrevia sua vida por meio de longas narrativas, como uma vida sem curiosidade, desinteressada, mas pudemos perceber que sua demanda inicial de análise fora, justamente, uma demanda por imaginação, pela possibilidade, ainda impossível, de sonhar um Godot. Desse modo, percebemos que, nessas narrativas, ele se afastava de uma relação irreal e descrevia como sua vida parecia ser um teatro do absurdo. Suas narrativas passaram a ter, assim, uma tonalidade crítica, que passamos a ouvir atentamente, sem realizar grandes intervenções; apenas demonstrávamos que estávamos ali e acompanhávamos aquilo que ele nos falava do modo mais atento que podíamos. Percebemos que suas narrativas representavam a 
necessidade de permanecer afastado da cena e de observá-la como um espectador, para depois conjecturar a respeito dela. Certamente, muito de imaginativo havia nesse conjecturar.

Ele passou a usar as sessões com esse propósito, embora dissesse que elas eram um parêntese na sua vida. Interpretamos isso como a impossibilidade do paciente de poder imaginar quando estava fora do "ambiente" de análise e percebemos que o fato de ele poder ser seu próprio observador decorria da possibilidade de experimentar, sem horror, sua solidão, tendo alguém que o acompanhava sem intrusão e que permanecia também distante dele. Permanecemos comovidos quando percebemos que sua realidade perdida permanecia, como em A carta roubada ${ }^{28}$ bem diante de nós: residia na possibilidade de imaginar o "outro palco", do qual permanecemos permanentemente excluídos, conservando-o preservado; mas residia na possibilidade de imaginar o "outro palco" tendo alguém que pudesse ser seu espectador silencioso das cenas que narrava. Esse outro palco, parece-nos, é a própria manifestação da alteridade/diferença do Real.

Nessa ocasião, Carlos resolveu voltar a estudar; não um estudo para que pudesse administrar melhor a fazenda, mas resolveu fazer um curso sobre restauração e voltou a desenhar, uma antiga atividade importante e renegada. Resolveu fazer ambas as coisas sem conversar antes conosco sobre esses assuntos e também sem conversar com ninguém. Contounos que era algo que vinha pensando há muito tempo com seus botões, imaginando. Lembramonos de Winnicott (1963/1982b), que disse: "Embora as pessoas normais se comuniquem e apreciem se comunicar, o outro fato é igualmente verdadeiro, que cada indivíduo é isolado, permanentemente sem se comunicar, permanentemente desconhecido, na realidade nunca encontrado." (p. 170). Pensamos que havia uma distância significativa entre os aspectos mais verdadeiros de seu $e u$, que se conservavam apartados e cindidos, e aqueles aspectos de sua

\footnotetext{
${ }^{28}$ Nesse conto de Edgard Allan Poe (1848/1978), a carta roubada, na verdade, encontrava-se em cima da lareira, bem diante de todos aqueles que a procuravam por toda a residência.
} 
personalidade que dominavam seu contato com a realidade, com a função de destruir as ligações amorosas do paciente com ela.

No ano seguinte de análise, houve algum progresso pelo fato de a análise ter menos uma função de entretenimento e mais uma função de compreensão de seus estados mentais, conforme eles ocorriam nas sessões, mas, no fim desse ano, o paciente começou a se questionar sobre a função de sua análise e sobre o sentido de suas idas às sessões, o que nos pareceu algo importante, de modo que incentivamos sua reflexão sobre o assunto. Em determinada sessão, o paciente, logo no início, falou-nos que gostaria de conversar sobre sua permanência ou não na análise; disse que não via sentido em continuar, pois, na verdade, a análise pouco prestava para ele e, em seguida, que ela servia para que ele falasse sobre as coisas cotidianas, o que ele não aguentava mais. Disse que isso não tinha relevância na sua vida como um todo e que parecia que era apenas um parêntese que ele fazia no seu dia. Em resumo: não havia razão de continuar vindo.

Depois de um silêncio, falou que nós havíamos lhe falado duas coisas importantes na última sessão, que o ajudaram: sobre seu aniversário e sobre seu companheiro. Falamos, então, que ele poderia reconhecer algo que era feito por alguém, alguma contribuição, ou permanecer sem reconhecer nada, nenhuma contribuição. Ele ficou um pouco em silêncio e falou, em um grande estado de tensão: "Eu acho que isso é uma ideia meio comum, meio banal, mas eu acho mesmo que sou muito egoísta." Dissemos que ele estava percebendo o quanto poderia deixar de considerar a existência do outro. Então, o clima emocional na sessão ficou realmente muito tenso. Depois de um pequeno silêncio, em que o paciente ficou com um aspecto extremamente sombrio, disse que era isso mesmo, que, na verdade, ele não tinha interesse nenhum mesmo, por ninguém. "Digo que me importo com minha mãe, com meu namorado, com as pessoas, mas na verdade eu 'tô' pouco ligando, eu não quero saber de ninguém." Começou, em seguida, a fazer um movimento com as mãos que parecia com de uma penetração. Falamos: "Como você não se 
deixa penetrar por ninguém, você acha que pode ficar penetrando a si mesmo e se bastando nisso... acha que pode não ter problema em ficar nessa situação. Você acha que pode acabar com aquilo que é criativo, bom, que se produz com alguém numa relação..." Então, o paciente emendou, dizendo: "Eu acho que tudo é irreal." Falamos: "Mas como você pensa que poderia haver realidade sem os outros?" No entanto, depois dessa nossa pergunta, ele simplesmente respondeu: "Ninguém me interessa..."

A expressão do paciente era de um grande ódio em relação às pessoas e à triangulação edípica. Tratava-se de um ódio aos relacionamentos, às ligações com objetos bons; ele destituía esses objetos de suas reais possibilidades e tornava-os dotados de certa irrealidade, marcada pelo uso deles em experiências masturbatórias relacionadas com o entretenimento. Mas o seu ódio, nesse momento, voltava-se contra nós e contra sua análise, que era percebida como algo que poderia criar com ele uma determinada experiência emocional criativa: nós éramos, agora, um casal parental criativo. Interpretamos sua inveja como em relação ao fato de que ele achava que sua análise e nós éramos os protótipos do casal parental que o excluiria da cena primária. Há uma passagem de Bion (1959/1994f) que ilustra bem o que acontecia nesse momento:

O ponto conhecido que não interpretei, mas relevante para o entendimento desse episódio, é que a inveja que o paciente tinha do casal parental havia sido contornada através da substituição dos pais pela sua pessoa e a minha. Essa fuga malograra, pois a inveja e o ódio agora se voltavam contra ele mesmo e contra mim. O casal empenhado num ato criativo era encarado com estando compartilhando uma invejável experiência emocional; ele, identificando-se também com o elemento excluído, passava por uma dolorosa experiência emocional. Em diversas ocasiões o paciente, em parte devido a vivências do gênero que descrevo no presente episódio, em parte por motivos sobre os quais me estenderei mais adiante, tinha ódio às emoções e, portanto, como decorrência quase imediata, ódio à própria vida. Esse ódio contribuiu para o ataque assassino ao que liga o par, ao próprio par e ao objeto gerado pelo par. No episódio que ora descrevo, o paciente sofre as consequiências de seus antigos ataques ao estado de espírito que forma a ligação do par criativo. (p. 117). 
Esse par criativo, originariamente denominado casal parental, é também a possibilidade de experimentar a existência do "terceiro analítico" (Ogden, 1996a), ou seja, no campo de forças intersubjetivas entre paciente e analista, o terceiro analítico é aquele sujeito inconsciente indeterminado que é construído conjuntamente, aquilo que é a expressão dos sonhos e dos pesadelos comuns da dupla. Contudo, a nossa ligação emocional era constantemente destruída, de modo que a experiência de vir às sessões era sempre um "parêntese em seu dia", uma experiência sempre a ser desfeita. $\mathrm{O}$ seu ódio pelas relações amorosas e construtivas era a base da expressão sobre seu desinteresse pelas pessoas. Embora demonstrasse se importar com os outros - e muito, no começo de sua análise -, essa demonstração não era suficiente para que a destrutividade não prevalecesse. Parece que sua procura por tratamento decorreu principalmente disso: da percepção dessa demonstração de preocupação em relação aos outros e de seu sentimento de que alguém sofria nele, ou seja, de que algo em si estava adoecido e recolhido, do mesmo modo como se referia a seu companheiro.

A inveja e o ódio do paciente ao casal parental e a impossibilidade de imaginação da cena primária fizeram com que nos voltássemos para uma compreensão sobre o complexo de Édipo, a partir dessa problemática; encontramos em Kancyper (2008) alguma resposta para nossas inquietações. Na tragédia de Sófocles, Édipo é retratado de modo um pouco diferente daquele que é enfatizado por Freud (1913/2006p, 1918/2006q) ao longo de seus trabalhos; a sua maior diferença reside no fato de que Freud acentua o fato de que Édipo encena um desejo incestuoso e parricida, que é levado a termo. Na tragédia tebana, por sua vez, há uma encenação trágica sobre um destino humano inexorável, sobre o qual não se é possível deliberar, que é o papel de Édipo como carrasco de um pai que fora culpado dos crimes de filicídio e, posteriormente, de violentar um jovem desejado: Crísipo. O pai filicida, Laio, que merecia ser castigado, é a origem do processo parricida e incestuoso. 
Segundo alguns autores (Rascovsky \& Rascovsky, 1968; Kancyper, 2008), esse parricídio e incesto seriam, assim, decorrências da impossibilidade de elaboração de uma identificação positiva com os objetos iniciais, especialmente com a figura paterna, que "antes do nascimento de Édipo já tinha investido uma identificação tanática suicida com o filho.” (Kancyper, 2008, p. 239). A decorrência desse investimento tanatolítico, ou desinvestimento, é a negação da existência dos pais, que se tornarão objetos dos impulsos de Édipo, sem que fosse efetuada a elaboração da repressão contra o incesto e o parricídio, ou melhor, contra aqueles que poderiam ser seus pais e objetos de seu interesse, identificação e amor. Nesse sentido, para Édipo, seus pais - Laio e Jocasta - não eram seus verdadeiros pais; sua orfandade parece ser, ao lado do filicídio, aquilo a partir do que se funda a tragédia.

Édipo, esse existente que deveria não existir, experimenta sua orfandade no não reconhecimento de sua filiação. Assim, sendo ele aquele que é nascido órfão, pôde manter seu desinteresse em relação aos pais e manter-se órfão ao longo da vida; uma orfandade que lhe mantém desabrigado, mas que simultaneamente deixa-o livre da repressão, da culpa e do remorso. Sua orfandade, esse traço importante de Édipo, não pode ser compreendida como a fantasia de morte do pai, mas como o desabrigo decorrente da experiência direta e sem intermediação representacional com a própria condição Real da existência humana, como também da ausência de paternidade e da falta de identificação positiva com os objetos primários, gerando uma ausência de sentido na experiência de triangulação edípica. Poderíamos dizer que a decorrência desse estado de desabrigo será a ampliação de uma atitude narcísica em relação aos objetos libidinais.

Rosenfeld (1988) discutiu pormenorizadamente o problema do narcisismo na idade adulta, com especial ênfase na qualidade das relações objetais estabelecidas por esses pacientes, quando predominava aquilo que ele designou como "narcisismo destrutivo", uma atitude depreciativa, por meio de uma atitude indiferente persistente, de comportamento repetitivo e às 
vezes de franco menosprezo, na qual os aspectos destrutivos do self são idealizados, havendo uma submissão a eles, de modo a capturar seus aspectos dependentes e positivos. Para esse autor, esses pacientes sentem, ocasionalmente, vergonha e um pouco de ansiedade persecutória, mas apenas uma culpa mínima, porque uma parcela muito pequena de seu self libidinal é mantida viva. Ainda, segundo Rosenfeld (1988),

ao considerarmos o narcisismo a partir do aspecto destrutivo, observamos que a idealização do self mais uma vez desempenha um papel fundamental, mas agora são as partes destrutivas e onipotentes do self que são idealizadas. Elas são dirigidas contra qualquer relação objetal libidinal e positiva e contra qualquer parte libidinal do self que sinta a necessidade de um objeto e o desejo de depender dele. As partes onipotentes e destrutivas do self freqüentemente permanecem disfarçadas ou podem ser não-manifestas e cindidas, o que oculta sua existência e dá a impressão de que elas não têm nenhuma relação com o mundo externo. Na verdade, elas têm um efeito muito forte na prevenção de relações objetais dependentes e na manutenção de objetos externos permanentemente desvalorizados, o que explica a aparente indiferença do indivíduo narcisista em relação a objetos externos e ao mundo. (p. 140).

Durante a análise de Carlos, pudemos perceber como ele fazia com que qualquer atitude que denotasse progresso, desenvolvimento pessoal ou insight fosse negada ou posteriormente desfeita. Embora ele não tivesse parado sua análise, fez com que seu trabalho de análise transformasse-se, primeiramente, em algo que não poderia se desenvolver - o entretenimento e, depois, em um "parêntese" que acabaria logo que ele saísse pela porta do consultório - ou seja, em insights e apreensão do mundo mental que eram consecutivamente desfeitos. A preponderância dos aspectos destrutivos em sua personalidade apenas tinha a função de afastar o self da criação de ligações objetais libidinais, em decorrência da ansiedade persecutória decorrente dessas ligações. O preço pago por Carlos foi o aumento do narcisismo e, principalmente, a impossibilidade de obter real sentimento de estar vivo e de ser real. 
Algum tempo depois, Carlos contou uma história que havia lido e que tinha o tocado muito. Tratava-se de uma história de As mil e uma noites, em que um gênio maligno, após ter aprisionado uma princesa, permanecia poderoso e onipotente. Ninguém conseguia salvá-la, até que um herói descobriu que o gênio maligno poderia ser derrotado caso o herói descobrisse sua fraqueza, que era apagar uma vela que ficava acesa dentro de uma montanha, escondida de todos. Assim, destruindo o gênio, o herói e a princesa puderam ficar juntos e ser um casal feliz. Após contar sua história, falou-nos com grande emoção que nunca tinha antes se emocionado com uma história de amor. Dissemos-lhe, então, que ele podia ficar mais emotivo e cheio de esperança quando pudesse imaginar a existência desse casal unido e quando seu gênio maligno invejoso pudesse parar de aprisionar a sua possibilidade de anseio por pessoas e de ligação amorosa. Foi instantaneamente que nos lembramos daqueles versos de D. H. Lawrence (1991), que dizem:

Até o ferro pode germinar,

Até o ferro.

Esta é a idade do ferro,

Mas vamos alegrar-nos

Ao ver o ferro abrir-se em botão,

O ferro enferrujado inflar em tufos de floração. ${ }^{29}$ (p. 65).

\subsection{Andarilho de Pés Inchados}

Apresentaremos, agora, a terceira narrativa clínica psicanalítica, que tem o propósito, assim como as outras duas, de ajudar-nos na tarefa de desvelamento daquilo que não poderá ser

\footnotetext{
${ }^{29}$ Os versos originais, extraídos do poema Almond blossom, publicado no livro Birds, beasts and flowers, de 1923, são estes: "Even iron can put forth,/ Even iron.// This is the iron age,/ But let us take heart/ Seeing iron break and bud,/Seeing rusty iron puff with clouds of blossom."
} 
desvelado, ou melhor, de poder apresentar vestígios de certa visitação do Real e como essa visitação relaciona-se com o problema do esquecimento e da ilusão.

\subsubsection{Considerações sobre Édipo}

Quem lê a tragédia Édipo Rei, de Sófocles, permanece, enquanto dura o enredo que antecede ao seu clímax, envolvido com outra cena; uma cena que ainda não está presente na peça. Essa cena apenas se tornará presente como uma lembrança de Édipo e corresponderá exatamente ao seu clímax, quase no final da peça. No entanto, muito antes disso, o espectador passa a imaginá-la - inicialmente de modo difuso, depois com mais clareza - e, diante dessa cena imaginada, vai progressivamente se envolvendo por terror e angústia. O clímax da peça ocorre no momento em que a cena passa a ser "sonhada"; um sonho, uma imagem horrível, ocorre como lembrança. Na forma dessa lembrança, Édipo rememora aquilo que havia ocorrido e que, assim, explicaria uma série de acontecimentos nefastos que se sucediam em Tebas e que pertenciam também à sua própria história. ${ }^{30} \mathrm{O}$ caminho para a lembrança foi efetuado por meio de algumas conversas, por vezes interpelações. Esse rememorar pode ser também designado como uma atividade de produção onírica ou de um sonhar restaurado. ${ }^{31}$

Como espectadores dessa tragédia, esperamos o momento em que Édipo irá se deparar com aquilo que já havíamos compreendido: com seu ato incestuoso e parricida, mas, embora isso possa ser sonhado ou imaginado pelo espectador, não é tão fácil para Édipo. Em sua conversa com Tirésias, por exemplo, ele se aproxima dessa "verdade" e se afasta dela, de modo quase pendular; assim, somente a aceita no momento em que pode ser por ele concebida, após

\footnotetext{
${ }^{30}$ Não há como não nos lembrarmos, quase que imediatamente, daquela célebre formulação que dizem ser de Nietzsche sobre o esquecimento, que diz que Deus criou o esquecimento como a soleira do templo da dignidade humana. Um templo que, como ethos humano, não pode prescindir dessa soleira.

${ }^{31}$ Usamos, deliberadamente, a expressão cunhada por Ab’Saber (2005) para designar um processo por meio do qual a atividade de sonhar pode ser novamente produzida, por meio da elaboração daquilo que não pôde ser ainda pensado. Tal assertiva encontra seu paralelo também em Bion (1957/1994b), quando afirma que os psicóticos não sonham ou que as partes psicóticas da personalidade são aspectos intoleráveis e não elaborados pelo psiquismo.
} 
diversos lampejos da verdade e diversos afastamentos dela. Essa rememoração é a produção imaginária de uma cena globalizante, uma costura dos vários elementos que não estavam encadeados como uma única história, uma construção ou reconstrução narrativa do passado. Por meio dessa nova cena, aqueles papéis até então conhecidos desfazem-se e surge a surpresa da existência de uma nova relação entre as pessoas antes conhecidas, agora novas figuras, assustadoras e cheias de horror. Nesse momento, há a eclosão de um profundo assombro e Édipo encontra-se destroçado pela cena concebida e também pela sua verdade, que ele perseguiu, a qualquer custo, até o fim. Nesse sentido, podemos também afirmar, como Bion (1957/1994b), que Édipo é aquele cuja arrogância anuncia-se pelas juras de desnudar a verdade, sem conhecer limites, por qualquer preço.

Assim, em Édipo Rei, somos levados aos poucos a imaginar ou sonhar com uma cena que é o produto daquela narração fantástica produzida por Sófocles. Essa cena, como sabemos, é a cena do incesto e do parricídio. O efeito profundo que ela provoca nos espectadores é proveniente dessa imaginação que vai sendo produzida em cada um, dessa cena não presenciada, mas que permanece diante de nós como uma realidade tenaz e da qual não se escapa. Podemos, assim como Édipo, titubear sobre ela, pela angústia que nos acomete, mas será apenas uma espera para aquilo que já tinha se anunciado como a verdade emocional, que irá, então, vagarosamente se aproximando, para produzir uma turbulência emocional vertiginosa.

Aquilo que ainda não podia ser sonhado por Édipo é sonhado pelos espectadores, que ficam envolvidos com a imaginação assustadora dessa cena primária não presenciada, em que a triangulação edípica ocorre por meio da possibilidade do espectador de vislumbrar o todo da cena. $\mathrm{O}$ espaço triangular, portanto, passa a existir primeiramente na mente do espectador, que se posiciona quando imagina a cena não presenciada da relação de Édipo com Laio e de Édipo com Jocasta. Assim, afirmamos, como Britton (2003), que o espaço triangular origina-se 
quando passa a existir uma posição a partir da qual o indivíduo pode ser um observador de uma relação entre dois outros e que o espaço da imaginação passa a existir quando essa relação é invisível, ou seja, não presenciada. O conflito edípico emociona e existe, primeiro, no espectador, sendo apenas depois vivido como uma emoção nos atores. Em outras palavras, primeiramente, o espectador ocupa a posição triangular que permite sonhar essa cena terrível, com o deslocamento da ação factual que se desenrola perante seus olhos... para que apenas posteriormente também Édipo possa vislumbrar horrorizado esse lugar. O descolamento da cena é, assim, a possibilidade para o surgimento da imaginação e do vislumbre do terror que poderá ser sonhado, tanto para Édipo quanto para os seus espectadores.

Enquanto isso, Sófocles, o escritor, mantém-se desaparecido... e, como a origem desse sonho, com o seu desaparecimento, tornará possível o aparecimento do ator que não consegue sonhar e desse sonho terrível que demanda ser sonhado... por alguém que não seja apenas aquele que pôde imaginá-lo, tornando-o escrita. Nesse sentido, Sófocles representa, de nosso ponto de vista, o mesmo que Shakespeare foi para Borges: "um homem sem ninguém dentro de si” (Ogden, 2010, p. 249); e que, assim, poderá desaparecer para não atrapalhar a si mesmo e ao leitor. Iremos retornar a esse tema posteriormente, para podermos pensar como o analista pode estar posicionado durante a situação analítica para o amadurecimento do analisando e para possibilitar o reconhecimento da visitação do Real, e pensaremos quais os desdobramentos de seu posicionamento.

Sabemos que falar sobre Édipo, assim como falar sobre psicanálise, é como falar sobre receitas culinárias. O melhor é provar, falar não nos traz o gosto. Talvez o melhor modo pra se falar sobre ele seja mesmo na situação de análise, uma vez que o Édipo mais relevante é aquele que poderá surgir em nós mesmos ou em nossos pacientes. Assim, sabemos que se trata de uma trama complexa, com diferentes vértices e diferentes possibilidades de aproximação; as camadas do palimpsesto - conforme foi discutido no capítulo anterior - sobre esse material são 
inúmeras. No entanto, nosso intento será o de promover o aparecimento não de uma camada mais profunda, feito que já procuramos mostrar como pode ser enganoso, mas daquilo que pode ser um espaço ainda insaturado dessa temática. Por isso, gostaríamos de sugerir que, com a chegada da testemunha do assassino de Laio, desencadeia-se a compreensão de ser Édipo o filho abandonado de Laio e Jocasta.

Esse abandono primevo, com seu desconhecimento sobre seus pais sanguíneos, faz de Édipo órfão de pai e mãe; sua orfandade é anterior a qualquer triangulação. Percebemos, assim, que havia um abandono e uma orfandade originários, que acompanham Édipo por toda a sua vida, como uma sombra diante da qual ele, embora procure, não consegue se evadir. Inicialmente, é verdade, não será uma orfandade pelo falecimento de seus pais; será uma orfandade produzida pela destruição da relação materna e paterna que havia até o momento de sua separação, mas sabemos, por outro lado, que ela pode não se configurar tão claramente assim: o desinvestimento de uma relação tanática suicida com o filho não pode ser esquecido (Kancyper, 2008) - como os Septizonium de Sétimo Severo sobre o Palatino de Roma, tal como Freud (1930/2006c) sugere-nos - e sua origem é certamente anterior ao abandono e à separação. A história contada por meio dessa peça de teatro pode ser compreendida como um modo de Édipo lidar, de diferentes formas, com sua condição de ser órfão, ou de ser originalmente desenraizado. Seu enredo fala de um processo de desilusão para a apreensão de uma condição humana mais primordial, destituída de pátria, paternidade e terra.

Sua orfandade aparecerá em diferentes momentos da peça. Ele saberá que é órfão de pai no clímax, embora essa ideia já estivesse presente antes de Édipo apropriar-se dela. Ele se tornará órfão também de mãe nos momentos seguintes a seu contato turbulento com a verdade, com o suicídio de Jocasta. Pouco tempo antes, ficará sabendo da morte de seus pais adotivos e, no final da peça, sem reino, sem pais sanguíneos ou adotivos, ele se tornará um andarilho que vive o desterro e a orfandade não mais como anseios inesgotáveis por paternidade e por terra, 
mas agora compreendidos e vividos como inteiramente seus, como um lugar sem lugar, como uma apreensão desiludida de sua Real condição humana.

\subsubsection{Desterro, Não Comunicação e a Ilusão do Andarilho}

Relataremos, brevemente, algumas passagens de um atendimento clínico psicanalítico em que um paciente comunicou-nos uma situação emocional verdadeiramente intensa, sentida de maneira dolorosa e pungente. Esse rapaz, que chamaremos Alex, estava em tratamento havia dois meses e tinha chegado até nós quando seu pai iniciou um namoro com uma jovem mulher, que o encantou profundamente. Seu encanto por ela, no entanto, fez com que a relação entre ele e seu pai e entre ele e a namorada de seu pai tornasse-se conflituosa e difícil. Pouco tempo depois, no ápice de sua angústia, começou a planejar um suicídio, sempre com meias palavras, com enormes silêncios entre seus planejamentos. Durante as sessões, percebíamos, em sua voz perturbada e baixa, ecoar um grito silencioso; tratava-se de silêncios nas sessões repletos de gritos mudos, que ecoavam no ar.

Em algum momento nesse período, Alex passou a andar com seu vizinho pelas redondezas, o qual passou a acompanhá-lo para onde quer que ele fosse. Esse vizinho, um rapaz mais jovem que nosso paciente, que tinha, na ocasião, 17 anos, passou a acompanhá-lo e a ouvilo, seguindo-o nas direções que tomava; era um "fiel escudeiro", que o acompanhava em seu desterro. Em certa ocasião, entre as inúmeras discussões com seu pai, ele saiu de sua casa, descalço, e foi andar, vagar pelo bairro, pela cidade, acompanhado pelo amigo. Seus pés inchados pelo caminho não encontraram abrigo e repouso em parte alguma; via-se só, sem casa, sem família, sem morada e com uma mistura estranha de sentimentos confusos. Sentia que sua vida estava por um fio: ele já sabia de seus sentimentos pela namorada de seu pai, uma mulher que fora carinhosa e atenciosa com ele, talvez tão diferente de sua mãe - impossível, talvez 
justamente pela excessiva proximidade - que, embora fosse colada, vivia próxima demais dele e não lhe inspirava qualquer sentimento amoroso. E aconteceu de modo repentino: em determinado momento, passou a sentir um enorme desejo de conversar com essa mulher, de adormecer ao seu lado, de ficar abraçado com ela... até seu pai e ela começarem a se sentir desconfortáveis e receosos.

Nas primeiras semanas de atendimento, acabamos como Édipo diante da Esfinge: desvendamos, arrogantes, a verdade de um apaixonamento, mas desvendar esse sentimento não serviu para desinchar os seus pés, que continuavam pés de andarilhos (Édipo ${ }^{32}$ ). Alex parecia, assim, fixar-se nessa instável situação; não se recriminava por sentir seu sentimento e parecia querer elaborar o fato de se sentir sem casa, sem lugar e sem referências claras de pai, de mãe, de família ou de leis. Incrivelmente, procurava se manter exatamente como estava e, desse modo, continuava a fazer longas caminhadas, andarilho sem destino, em desterro, carregando a consciência do terror de seus sentimentos.

Sentia muito ódio por seu pai. Seu ódio por seu pai era, no entanto, intercalado também por sentimentos bons, sentimentos de que não poderia sequer pensar em viver distante desse pai, que era para ele admirado e respeitado. Vivia ambivalente, pois sua admiração por seu pai não diminuía imensos sentimentos de ódio. Sua mãe, nesse momento, dizia-lhe que seu pai era realmente responsável por seu sofrimento e, por isso, ele deveria se afastar desse pai e permanecer mais próximo dela. E assim ele fazia, mas sentia-se angustiado com a excessiva proximidade dessa mãe, que o tratava de modo tão instável e queria que ele dormisse ao seu lado... No entanto, perturbado, não conseguia deixar de pensar em seu pai e, principalmente, na namorada dele. Telefonava para ela diversas vezes por dia e entrava em crise assim que alguma resposta frustrante de seu desejo aparecia do outro lado da linha.

\footnotetext{
${ }^{32}$ Édipo, em grego, significa pés inchados.
} 
Essa situação trouxe para ele velhas lembranças, que fizeram lembrar-se de sua história. Lembrou-se que não era filho desse pai, mas adotado por ele; lembrou-se que sempre sentiu medo de ficar sem nenhum pai, de acordar um dia e descobrir que não tinha pai algum. Tinha medo, por outro lado, de não se desenvolver, de ficar parado em casa, como tinha sido até então, silencioso, sem amigos, sem muitos interesses na vida, sem namorada, parado como um objeto silencioso... e, como agora a escola estava terminando e, com isso, todo o seu mundo conhecido, parecia que seus medos estavam perto de se realizar. Diante disso, Alex andava. Suas andanças pelo seu bairro e por lugares mais distantes eram andanças atormentadas e aconteciam quando ele não se sentia pertencente a nenhuma família, a nenhum lugar. Seu "lugar" - se pudéssemos assim dizer - estava no tormento e na aridez das ruas desabitadas. Às vezes, andava durante horas, com passos largos, que seu amigo tentava acompanhar. Parecia estar cego, enquanto queria apenas andar sem destino, pois não havia nada ao seu redor que lhe chamasse a atenção, uma vez que pessoas e coisas eram somente figuras escuras e difusas, que não tinham importância alguma. Seu “interior” em conflito era o que permanecia visível diante de seus olhos fechados.

Durante os atendimentos de Alex, começamos a notar que nossas conversas eram frequentemente interrompidas pela presença de um silêncio. Esse estado silencioso podia permanecer entre nós por bastante tempo, caso o paciente não fosse estimulado. Não era um silêncio tenso ou carregado; parecia ser um estado vazio, de ausência, uma espécie de sonambulismo. Durante nossas conversas, muitas vezes atormentadas, ele em algum momento ia se desligando, se desligando e apagava, embora continuasse de olhos abertos e olhasse algo, algum objeto da sala, como a cortina, por exemplo, ou o tapete, sempre com o olhar vago e distante. Pareceria adormecido, caso estivesse de olhos cerrados, mas seus olhos abertos e sua pronta resposta, caso interrogado por nós sobre o que estava pensando, por exemplo, não deixavam dúvidas de que estava acordado. No entanto, parecia que se tratava de um período de 
sonolência e de adormecimento. Pensávamos no que poderia lhe provocar isso. Ele comentava que tinha grande dificuldade de dormir e que apenas dormia quando estava completamente inundado de sono; mesmo assim, dormia bem pouco, a partir das três ou quatro horas da manhã. Permanecia sempre em alerta e pronto para dar uma resposta ou responder a algo para alguém. Notamos, assim, que naqueles momentos ele, embora continuasse pronto para dar uma resposta, também adormecia, adormecia em um sono de pirata, com um olho aberto e o outro fechado...

Nesses momentos de adormecimento, Alex não falava nada e sua fisionomia parecia sem cor e sem definição; não era um sono bom e também não se tratava de um sono ruim. Lembramo-nos, em determinada sessão, que ele havia nos contado que passava às vezes, quando criança, diversas tardes em seu quarto, longas tardes, em que não tinha nada, absolutamente nada para fazer. Longas horas de nada. Aturdido por um sentimento intenso de tédio, de falta de contato com alguém, passou a tocar guitarra para ocupar o silêncio daquelas tardes vazias, mas o silêncio continuou e aparecia agora nas sessões. Lembramos-lhe disso, desse antigo - e atual - estado. Ele não quis falar muito a respeito. Falou-nos (e já dava para esperar por isso) sobre suas aulas de guitarra e de como estava difícil encontrar uma banda para tocar; disse que se sentia só, só e sem contato emocional com alguém, embora quisesse, ansiasse por isso. Ele permanecia assim, embora estivéssemos ali com ele.

Alex, então, esfregou as suas mãos nos olhos, como se estivesse acordando, espreguiçou-se e disse: “Eu sei, eu sei...” Após ter dito isso, fomos tomados por um sentimento desagradável; nosso sentimento imediato era de que havíamos oferecido balas para um esfomeado... um paliativo inútil e desnecessário. Ficamos desconfortáveis com isso; não esperávamos nos sentir assim, mas percebemos que o paciente achava que ninguém poderia "matar sua fome", a não ser a satisfação completa de seu intenso amor, transgressor e apaixonado. Dissemos isso para ele, que, então, começou a falar de uma ideia que estava na sua mente há bastante tempo: mudar-se para outra cidade. Achamos que era uma comunicação 
íntima. Sua ideia de mudança, de ir para outro lugar, ocupou nossos pensamentos com atenção, não apenas pelo modo como foi comunicado, como uma palavra dita ao acaso, mas pelo clima de sua comunicação, que tinha em seu íntimo um ar de coisa guardada, de um pensamento secreto. Então, ocorreram-nos aquelas palavras que Winnicott (1963/1982b) escreveu sobre a não comunicação:

O rapaz ou a moça na puberdade podem ser descritos de várias maneiras, e uma delas se refere ao adolescente como um isolado. Esta preservação do isolamento pessoal é parte da procura por uma identidade, e para o estabelecimento de uma técnica pessoal de comunicação que não leva a violação do self central. Esta deve ser uma razão pela qual os adolescentes em geral evitam o tratamento psicanalítico, embora estejam interessados nas teorias psicanalíticas. Eles sentem que pela psicanálise podem ser estuprados, não sexualmente, mas espiritualmente. (p. 173).

Sentimos que era preciso, como nossa memória havia nos lembrado, considerar que essa ideia podia ser expressão daquela parte isolada de si mesmo, que procurou comunicar-se pelo seu sentimento, naquele momento, de que a intimidade não seria machucada ou agredida. Além disso, como ideia de uma mudança, ela nos pareceu um sonho que expressava o desejo pelo autêntico existindo no mundo, com um lugar possível em que a intimidade não fosse violada. Nesse momento, algumas ideias extremamente perturbadoras vieram em nossa mente. Uma delas foi: será que não estaria reproduzindo, por transferência, uma relação de invasão e agindo de modo a colocar seu $e u$ em risco? E isso, pronunciado na sessão, não denunciava também sua vontade de deixar as sessões? Esse pensamento gerou ainda outro sobre o seu sentimento de desrespeito em relação à intimidade, que Alex dizia ser comum em sua família. Lembramo-nos de seu pai telefonando-nos, procurando dizer, cheio de preocupação, como estava seu filho, repleto de ideias sobre ele; lembramo-nos também dos telefonemas de sua mãe, que sempre nos pareciam invasivos e ameaçadores. Por fim, lembramo-nos novamente de uma passagem de Winnicott (1963/1982b), na qual ele diz: 
O eu central não se comunica, para sempre imune ao princípio da realidade e para sempre silencioso. Aí a comunicação é não-verbal; é como música das esferas, absolutamente pessoal. Pertence ao estar vivo. E normalmente, é daí que se origina a comunicação. (p. 174).

Parecíamos estar situados, desse modo, entre um estupro psicológico e uma escuta da “música das esferas”... A música das esferas parecia ser aquilo que ocorria entre as suas palavras; entre as palavras faladas. Como disse Debussy (citado por Ogden, 1996b), a música é o espaço existente entre as notas e, como bem notou Ogden (1996b), algo similar pode ser dito sobre a psicanálise. A música de Alex, ou aquilo que havia entre as notas das palavras faladas, aquilo que era isolado e não comunicado, deveria permanecer fundamentando a própria comunicação. Tratava-se de algo paradoxal, conforme pudemos compreender: se, por um lado, Alex permanecia indicando um pensamento íntimo, proveniente de uma parte incomunicável, que deveria permanecer assim, por outro, tratava-se também da comunicação de um anseio, proveniente do anseio e da solidão, mas que ainda era pouco claro; certamente, estava ligado com sua ideia de ir para outro lugar. Mas seria um anseio por lugar? Que lugar seria esse?

Pensamos que, acima de tudo, o paciente transmitia-nos a impressão de permanecer estrangeiro em sua terra natal. Sua experiência de ser expatriado, desde sempre, conduzia-lhe para uma reafirmação de sua condição errante. Ele era estrangeiro em sua casa, com sua mãe, era estrangeiro com seu pai, não tinha seu lugar, mas ansiava por isso e seu anseio, um clamor, de uma preconcepção de lugar, que habitava seu psiquismo, parecia ser a fonte de tal movimento de seu pensar. Sua ideia de viajar, assim, parecia ser oriunda de uma situação emocional da qual nunca se distanciou completamente e que era simultaneamente seu próprio enlouquecimento: seu sentimento de ser originariamente desenraizado. Sentia não possuir raízes, terra e lugar. Assim, sua comunicação parecia-nos proveniente de uma parte sua não comunicada, de uma parte sua íntima e que deveria permanecer assim, mas que também não encontrava no mundo o lugar pelo qual realmente ansiava, o que tornava esse anseio um 
anseio sem fim. A casa, a família e o ethos de Alex não seriam, desse modo, somente ilusões perdidas, ilusões que não puderam manter-se como ilusões? E assim, perdidas, talvez prematuramente o deixassem convivendo enlouquecidamente com seus anseios, com sua preconcepção de um seio "bom” caracterizado como lugar?

Nas sessões que se seguiram a essa, Alex continuou de alguma forma tocando nesse ponto: queria manter-se iludido em relação ao seu amor pela namorada de seu pai. Queria chamá-la de mãe, mas era desiludido quase imediatamente. Dizia não aguentar a desilusão, mas não era apenas essa desilusão que não aguentava, sabíamos disso. Fora muito duro saber que seu pai biológico não quis conhecê-lo, que sua mãe sofria de fortes oscilações emocionais inexplicáveis, que seu pai tinha outra vida, distante dele, e que estava por um fio para romper as suas relações. Como, ao longo das sessões, percebia que era desiludido com tudo, tinha seu pensamento secreto: um outro lugar.

Depois de algumas semanas, ele viajou para a praia, onde morava um parente distante, e voltou muito animado; havia conversado com esse parente, que havia lhe convidado para ir morar junto a ele. Alex estava exultante; queria pensar em ir trabalhar em um lugar que havia conhecido, queria ir dividir o apartamento com esse parente, ter uma nova experiência. Ficamos bem preocupados com esse desejo de mudança repentina e procuramos conversar com ele sobre seus anseios e sobre como ele talvez estivesse idealizando um lugar que poderia apresentar enormes dificuldades para se viver. Alex disse que sentiria nossa falta, mas que estava realmente querendo ir. Seus pais, em decisão histórica, pois nunca concordavam com coisa alguma, aprovaram conjuntamente a sua mudança e, assim, ele foi para a praia, estudar e trabalhar. Recobrava, assim, uma nova ilusão, na esperança inconsciente que fosse forte o suficiente para fazer frente àquilo que era sua mais Real condição, mas também a origem de seu atordoamento e perturbação. Não queremos, com isso, dizer que sua Real condição era algo que pudesse ser dito ou formulado por Alex, ou seja, que ele poderia, por meio da 
representação, dela se defender, mas que ele conduzira-se para a ilusão, que poderia trazer-lhe a possibilidade de encontrar no mundo aquilo que ele próprio formulava como fundamental: uma forma de estabelecer um contato menos perturbador com sua realidade psíquica.

\subsubsection{Dissolução do Complexo de Édipo?}

Freud (1923/2006r), em sua discussão sobre a dissolução do complexo de Édipo, diz-nos que, em face do medo da castração real de seu pênis, a criança afasta-se do desejo por satisfação do seu amor vinculado a esse complexo, realizando outro processo associado com a identificação. Ele nos diz:

Se a satisfação do amor no campo do complexo de Édipo deve custar à criança o pênis, está fadado a surgir um conflito entre seu interesse narcísico nessa parte de seu corpo e a catexia libidinal de seus objetos parentais. Nesse conflito, triunfa normalmente a primeira dessas forças: o ego da criança volta as costas ao complexo de Édipo. Descrevi noutra parte como esse afastamento se realiza. As catexias de objeto são abandonadas e substituídas por identificações. A autoridade do pai ou dos pais é introjetada no ego e aí forma o núcleo do superego, que assume a severidade do pai e perpetua a proibição deste contra o incesto, defendendo assim o ego do retorno da catexia libidinal. As tendências libidinais pertencentes ao complexo de Édipo são em parte dessexualizadas e sublimadas (coisa que provavelmente acontece com toda transformação em uma identificação) e em parte são inibidas em seu objetivo e transformadas em impulsos de afeição. Todo o processo, por um lado, preservou o órgão genital - afastou o perigo de sua perda - e, por outro, paralisou-o - removeu sua função. Esse processo introduz o período de latência, que agora interrompe o desenvolvimento sexual da criança. (Freud, 1923/2006r, p. 46-47).

Freud (1923/2006r) descreve um processo que se complexifica basicamente por conta de dois fatores: a bissexualidade constitucional de cada pessoa e o caráter triangular da situação edipiana. Na identificação descrita pelo autor, o caminho mais comum descrito na sexualidade 
masculina $^{33}$ seria a identificação com o pai. Com essa identificação, o afeto desenvolvido pela mãe seria de certo modo mantido, mas sem a intensidade desempenhada anteriormente. $\mathrm{O}$ medo da castração, portanto, seria o motor para a identificação. Mas sobre o que esse medo dirige-se? Isso não parece ser tão difícil de responder, uma vez que o medo desempenha um papel fundamental na tentativa de controle dos impulsos das crianças pequenas. Como nos conta Tuan (2005):

A possibilidade de abandono, um medo profundo entre as crianças, ocorre mais frequentemente do que os adultos estão dispostos a admitir, em parte porque eles podem tê-lo usado como uma ameaça eficaz para controlar um infante teimoso. Os contos de fadas reconhecem essa ameaça e esse medo. Os pais são representados como tendo expulsado seus filhos usando diferentes formas de força. Um homem e sua mulher, na avidez pelo rapôncio do jardim da feiticeira, prometem the dar o seu primeiro filho. Quando a feiticeira aparece para reclamar a criança, os pais não protestam com muita energia. João e Maria são abandonados duas vezes por seus pais. Na história 'Os Dois Irmãos', um irmão acusa os filhos gêmeos do outro irmão de ter um pacto com o diabo. O pai teme o demônio e, apesar da dor que isso representa para ele, leva as crianças para dentro da floresta, e com o coração triste as deixa lá. (p. 32).

O medo da castração - e do abandono - desempenha um papel fundamental nesse momento em que o complexo de Édipo é desfeito. Mas será que ele realmente é desfeito? Em Totem e tabu, Freud (1913/2006p) descreve que, após a morte do pai dominador, no mito da horda primitiva, os seus filhos reuniram-se de modo a dividir as fêmeas igualitariamente. Nessa divisão igualitária, o medo ainda permanece. A divisão torna-se igualitária pela possibilidade de algum filho tornar-se realmente igual ao pai. Desse modo, podemos compreender as palavras do autor quando diz:

\footnotetext{
${ }^{33}$ Torna-se importante lembrar que essas ideias de Freud (1923/2006r) foram elaboradas em um período anterior a 1930, o que equivale dizer que foram marcadas por esse período histórico. Embora possamos ter em mente as tentativas freudianas de constituir um pensamento estrutural da mente humana, que, como ciência, pudesse ser necessário e universal, sabemos que nossa clínica contemporânea propõe questões que são, de certo modo, diferentes daquelas que levaram Freud a elaborar suas ideias; por exemplo, a de que o resultado mais normal do complexo de Édipo seria a identificação do menino com o pai.
} 
O superego, contudo, não é simplesmente um resíduo das primitivas escolhas objetais do id; ele também representa uma formação reativa enérgica contra essas escolhas. A sua relação com o ego não se exaure com o preceito: 'Você deveria ser assim (como o seu pai)'. Ela também compreende a proibição: 'Você não pode ser assim (como o seu pai), isto é, você não pode fazer tudo o que ele faz; certas coisas são prerrogativas dele'. (Freud, 1923/2006r, p. 36).

Essa força da censura e da repressão contra os antigos objetos do id decorre, ainda, do medo da castração. Não ser igual ao pai, respeitando as prerrogativas dele, significa que a criança coloca em devir o seu desejo, não por conta apenas da realidade factual, mas por conta de uma realidade psíquica: o medo da castração ou da perda abrupta da sua onipotência. Somente esse medo é que faz com que a criança queira ser igual ao pai; somente assim, com uma ideia de que o pai é onipotente, com essa visão idealizada do pai, poderá suportar a ideia de que é possível conviver com a desilusão da onipotência, de possuir tudo aquilo que se desejou, sem consequências, pois no futuro próximo poderia reconquistar tudo aquilo que sente que precisou abrir mão, tornando-se igual a seu pai. Diante dessa ilusão, parece poder tolerar uma provisória castração, marcada sob a forma da repressão, que se mostrará não exatamente provisória, mas permanente e a sua permanência decorre somente da existência do medo.

O medo da criança, o medo da castração, é o medo de perder aquilo que lhe assegura um sentimento de confiança em si mesma, em um período da vida em que as crianças dependem fundamentalmente de outros para a sua sobrevivência. O medo de ter seus anseios frustrados, de se ver sem aquelas coisas que lhe são fundamentais, dá a ele o peso e a importância que realmente tem. A castração, desse modo, não se dirige ao pênis. Ela se dirige àquilo que torna a criança realmente pertencente a uma família, a uma casa, a uma comunidade humana, possuidora de objetos que lhe são caros e diferentes dos demais em importância, sentido e valor. O medo da castração dirige-se àquilo que pode ser apenas pressentido pelas crianças: que elas anseiam por paternidade, por terra, por coisas e pessoas. Em outras palavras, o medo da castração, caracterizado onticamente como o medo de perder o pênis, é, no entanto, um medo 
mais fundamental, que possivelmente não pode ser denominado medo. Será que não poderíamos, como Heidegger (1949/1984b), designá-lo como angústia? Não seria sua diferença caracterizada pelo modo como habitualmente compreendemos o medo, como temor diante de um ente ameaçador? Contudo, o medo da castração, que destitui a criança de sua própria onipotência, leva-a a uma perda de apoio naquelas coisas que lhe eram anteriormente conhecidas e estáveis.

Na angústia - dizemos nós - 'a gente se sente estranho'. O que suscitar tal estranheza e quem por ela é afetado? Não podemos dizer de que a gente se sente estranho. A gente se sente totalmente assim. Todas as coisas e nós mesmos afundamo-nos em uma indiferença. Isso, no entanto, não no sentido de um desaparecer, mas em se afastando elas se voltam para nós. Este afastar-se do ente em sua totalidade, que nos assedia na angústia, nos oprime. Não resta nenhum apoio. Só resta e nos sobrevém - na fuga do ente - este nenhum. (Heidegger, 1949/1984b, p. 39).

Heidegger (1949/1984b) aponta-nos que o mundo que se apresenta a partir da experiência da angústia é um mundo em que os entes penetram em uma dimensão de estranheza, de modo a serem destituídos de um todo organizado e coerente. Abre-se uma porta para o aparecimento da ausência ou, nas palavras do próprio autor, do nada. A angústia heideggeriana parece-nos a mais fundamental explicitação daquilo que deve surgir para a criança em sua experiência com a castração. Diante de sua surpresa com aquilo que lhe era conhecido - sua ilusão de conhecer a si mesmo, como ser onipotente e criador, que cria aquilo que está lá para ser criado (Winnicott, 1971/1975) -, diante de seu assombro em face de uma diferença inconcebível, que lhe retira tudo o que lhe era anteriormente conhecido, assim podemos compreender a castração: como a estranheza da criança em relação àquele estranho outro que lhe surge retirando a familiaridade do mundo e deixando-a diante do seu desabrigo e risco existencial. O nada, ele diz, "revela este ente em sua plena, até então oculta, estranheza como o absolutamente outro - em face do nada." (Heidegger, 1949/1984b, p. 41). 
O medo da castração, como um medo entificado, ou seja, como um medo representado, o medo de perder o pênis pela castração paterna, não consegue abarcar a sua dimensão originária ou para onde o medo aponta. Procuramos, assim, dizer que uma direção desse medo reside na apreensão do outro ou, como Heidegger (1949/1984b) diz, do absolutamente outro, diante do qual a criança, de modo vertiginoso, apreende a alteridade, a diferença existente entre coisas, pessoas e mundo, e um mais além inapreensível. Em face dessa diferença, ocorre a castração, no momento em que a estranheza da realidade apresenta-se para ela como interrogação, indagação e possibilidade de poder pensar. O medo da castração, assim, pode ser também compreendido como a perda do mundo conhecido, a perda de um mundo em que coisas e pessoas apenas se distinguem vagamente e tudo parece unido em uma espécie de familiaridade que a tudo destitui, por nivelar as possibilidades de cada coisa e de cada pessoa. Estamos, desse modo, procurando dizer que, com a angústia, que advém, entre outros modos, pela castração, sobrevém o outro, a diferença para a qual a criança remete-se e, com isso, pode pensar e ser aquilo que estava lá para ela, com a estranheza, ser e pensar.

Sem a abertura originária do nada, não haveria nem si-mesmo nem liberdade. Num comentário ao seu próprio ensaio 'O Que é a Metafísica', Heidegger escreveria que, diferindo de uma indagação vaga, o nada visa ao outro, distinto do ente, alcançando a abertura pela qual algo assim como ser possa ocorrer. (Nunes, 1992, p. 115).

Assim, como poderíamos compreender, agora, uma dissolução do complexo de Édipo? Uma dissolução desse complexo não pode ocorrer sem que o resultado não seja uma mudança significativa no modo de apreensão do mundo, de forma que uma extravagante diferença surja nesse desabrigo da angústia. Não é isso justamente o que ocorre com Édipo?

Jocasta ouve o mensageiro expor que Édipo era um recém-nascido levado ao palácio, adotado em seus primeiros dias pelo rei e pela rainha de corinto. Não era o filho de suas entranhas, mas o 
casal quis que Corinto fosse a sua cidade. Jocasta tem uma intuição sinistra. Se já não tivesse parcialmente adivinhado, agora estava tudo claro. Ela sai do local da conversa e entra no palácio. 'Como sabes isso?', Édipo pergunta ao mensageiro. 'Eu sei', ele responde, 'porque fui eu mesmo que entreguei a criança aos meus patrões. Entreguei-te, a ti, a criança do calcanhar perfurado'. 'Quem te dera a criança?', pergunta Édipo. O mensageiro reconhece na assistência o velho pastor que antigamente guardava os rebanhos de Laio e Jocasta, aquele que lhe confiou o recém-nascido. Édipo se aflige. O pastor nega. Os dois homens discutem. 'Mas tu te lembras muito bem, estávamos com nossos rebanhos no monte Citerão e foste tu que me entregaste a criança'. Édipo sente que as coisas estão tomando um rumo aterrador. Pensa por um instante que talvez fosse apenas uma criança encontrada em algum lugar, o filho de uma Ninfa ou de uma deusa, abandonada ali, o que explicaria o destino excepcional que fora o seu. Ainda nutre uma louca esperança, mas para os idosos reunidos surge a verdade. Édipo se dirige ao pastor de Laio e o exorta a dizer a verdade. 'De onde vinha essa criança?' 'Do palácio'. 'Quem te dera?' 'Jocasta.' Nesse instante, não há mais sombra de dúvida. Édipo compreende. Como um louco, sai correndo até o palácio para ver Jocasta. Esta se enforcou com seu cinto, no teto. Ele a encontra morta. Com as presílias de seu vestido, Édipo fura os olhos, ensangüentando os globos oculares. (Vernant, 2000, p. 173-174).

Nessa passagem contada por Vernant (2000), somos levados ao ponto central do clímax da história de Édipo. Podemos notar, lendo atentamente, que Édipo apreende a verdade que estava emergindo intuitivamente antes mesmo de estar inteiramente representada e dita. Os idosos já a haviam compreendido e permanecem silenciosos. Ele se torna enlouquecido quando não há mais dúvida sobre ela e quando se torna aquilo que a verdade apontou. O personagem mostra-nos a diferença entre compreender algo e ser algo (Bion, 1965/1994a; Meltzer, 1998); podemos dizer que ele não compreende a angústia, pois se torna a própria angústia e aquilo para o que ela aponta.

Há uma verdade que irrompeu e ela é avassaladora, porque mostra Jocasta e ele próprio como absolutamente diferentes daquilo que pareciam ser em sua familiaridade cotidiana. $\mathrm{O}$ assombro de Édipo, o seu terror, é estar diante de sua própria imagem refletida nessa verdade, nesse espelho que o assombra pela imagem da terrível diferença entre aquilo que existia e aquilo de novo que se revelava. As ilusões desvaneceram; a dúvida, nesse momento, também se 
dissipou. No acontecimento da verdade, a alteridade surge. No entanto, a surpresa diante de sua diferença somente foi possível quando ele se mostrou disposto a ir até o fim com sua ânsia de pesquisador. Estava ele querendo arrogantemente a verdade e não parou diante daquilo que as pessoas geralmente param: o pressentimento da angústia.

Édipo, que parecia não sentir angústia, foi destroçado pela verdade, não simplesmente pela temática sexual ou do assassinato do pai, pois podemos afirmar que, em certo sentido, o crime sexual é um elemento periférico da história (Bion, 1957/1994b), mas pela atordoante alteridade/diferença que surgiu diante de seus olhos. Essa expressão da verdade foi, assim, deveras intensa. Posteriormente, ele se torna cego, como aquele que tem os olhos abertos para tudo aquilo que os olhos impedem-nos de ver.

Certamente, não há como não nos lembrarmos daquela recomendação de Freud (citado por Grotstein, 2010) a Lou Andréas Salomé, de que o analista deveria ter a possibilidade de cegar-se artificialmente durante as sessões para concentrar toda a sua atenção sobre o ponto obscuro. Bion (1970/1991a) explora esse ponto de vista, afirmando que "desconsiderar o que em geral se entende por realidade não implica inconveniência para o propósito de alcançar o contato com a realidade psíquica, isto é, as manifestações que evolvem de O.” (p. 54). Parece, com essa afirmação, querer dizer que a cegueira pode ser um modo de obter contato não com aquilo que usualmente pensamos ser a realidade, mas com a realidade psíquica não sensorial, que apareceria no ponto obscuro de nossa incompreensão. Trata-se de um método de obtenção de um saber e de ser, não só de se conhecer algo que se desconhece.

Nietzsche (1873/1978b), em sua obra da juventude intitulada Sobre a verdade e mentira no sentido extra-moral, declara:

O que sabe o homem propriamente sobre si mesmo! Sim, seria ele sequer capaz de alguma vez perceber-se completamente, como se estivesse em uma vitrine iluminada? Não lhe cala a natureza quase tudo, mesmo sobre seu corpo, para mantê-lo à parte das circunvoluções dos 
intestinos, do fluxo rápido das correntes sanguíneas, das intrincadas vibrações das fibras, exilado e trancado em uma consciência orgulhosa e charlatã! Ela atirou fora a chave: e ai da fatal curiosidade que através de uma fresta foi capaz de sair uma vez do cubículo da consciência e olhar para baixo, e agora pressentiu que sobre o implacável, o ávido, o insaciável, o assassínio, repousa o homem, na indiferença de seu não-saber, e como que pendente em sonhos no dorso de um tigre. De onde neste mundo viria, nessa constelação, o impulso à verdade! (p. 46).

O autor, nesse momento, formula a verdade como um impronunciável e terrível saber, sendo que, na indiferença de seu não saber, mantém-se o homem sonhador em um mundo sonhado, aranha pendente em sua teia (Pessanha, 2000), insensível aos buracos por onde passa o vazio escuro da noite. Esse homem, iludido sobre si mesmo, sonha enquanto permanece no dorso de um tigre, de sua própria natureza indomável, incompreensível, feroz e assassina, da qual se separa, segundo Nietzsche (1873/1978b), pelo orgulho e falsidade de uma consciência que se mantém equivocada e surda, como quem se tranca em um confortável cômodo e desconhece o restante de sua própria casa; assim, enquanto esse cômodo permanece um cômodo de ilusões, o restante da casa é a evidência de uma crua realidade, da desconhecida alteridade de nós mesmos. Com essas reflexões duras e mordazes, o autor convida-nos a uma reflexão sobre a necessidade de a consciência não saber, de iludir-se, para se manter fiel às suas próprias convicções, moral, dignidade e certezas.

Bion (1967/2000a) denomina angústia catastrófica essa aproximação viva de nossa verdade, de uma ideia nova ainda não pensada; com isso, ele quer dizer que pensar uma ideia nova é o prenúncio de uma aproximação com determinada experiência emocional. Pensar não tem nenhuma relação, assim, com a racionalização ou com a teoria. A mudança que é pressentida como catastrófica é a mudança que decorre do contato emocional com uma força disruptiva e violenta; trata-se da aproximação de nossa verdade emocional, uma verdade que promove uma mudança psíquica intolerável. Como nos dizem Grimberg et al. (1973), “assim 
um novo descobrimento violenta a estrutura de uma teoria preexistente, um revolucionário a estrutura da sociedade, uma interpretação a estrutura da sociedade.” (p. 38).

Tal verdade que nos acossa e que nos clama por seu encontro é, geralmente, almejada e rejeitada. Quando Freud (1895/2006g) indicou-nos, pela primeira vez, o fenômeno da resistência, ele percebeu que era ela que entravava o trabalho terapêutico. Lembrando Nietzsche (1978b), poderíamos dizer: jogamos a chave fora, pois paradoxalmente queremos e não queremos encontrá-la; queremos encontrá-la, mas não queremos sofrer com o seu achado. No entanto, se, por um lado, a verdade impronunciável acossa-nos e nos indica uma mudança psíquica intolerável, por outro, a verdade é aquilo que nos oferece o verdadeiro alimento à mente, aquilo que de fato nutre e pode ser o conteúdo capaz de fazer uma mente desenvolver-se e se manter viva (Bion, 1967/2000a).

Castelo Filho (2009) torna esse ponto de vista bastante nítido ao comentar a tragédia ática de Édipo Rei:

Sófocles inicia sua tragédia com Édipo reinando. Acaba com Édipo, que pensava tudo saber, se dando conta de sua prepotência e de sua arrogância. Da presunção (onipotência) chega-se à humildade necessária ao aprendizado com a experiência da vida. Todo nosso conhecimento é sempre precário e transitório, à espera de novas experiências que possam reconfigurar tudo aquilo que percebemos. Em psicanálise, o que importa não é aquilo que acreditamos saber, mas sim aquilo que ignoramos por completo. O vértice precisa ser o desconhecido, para que não fiquemos como Édipo, cegos por aquilo que acreditamos sejam os fatos. (p. 263).

Há um risco, nesse sentido, de que, ao sabermos sobre aquilo que ignoramos, apenas passamos a saber um pouco mais sobre aquilo que ignoramos completamente. Assim, o que ignoramos por completo não será substituído por uma crença ilusória de sabermos um pouco mais? A análise não poderia ser confundida com essa meta?

A história de Édipo convida-nos a um mergulho paradoxal entre a ilusão e a desilusão: não seria a vida humana um acontecimento transiente entre a ilusão e a desilusão? Nesse 
sentido, não seria também uma tarefa psicanalítica observar o valor inerente da ilusão para o ser humano, de modo que a busca da verdade não se torne uma arrogante busca pelo próprio destroçamento? Assim, talvez possamos compreender melhor a importância da ilusão e voltar nossos olhos novamente para Alex, a fim de continuarmos nossa investigação clínica.

\subsubsection{Uma Continuidade Sem Fim}

Alex ligou-nos após alguns meses, para dizer que estava bem, que estudava e queria fazer uma faculdade. Estava bem-humorado e, quase no final da ligação, contou que estava saindo com uma mulher casada, por quem havia se interessado... Seu tom de voz era malicioso e transgressor, mas também estava cheio de humor; sentimos que ele fazia uma transgressão como aquela que havia procurado, pelo menos fantasiosamente, fazer alguns meses antes. Contou-nos detalhes dessa inusitada situação, repletas de um enorme colorido emocional e imaginativo, que nos fizeram ficar posicionados como aquele que observa uma relação imaginada de outros dois. Enquanto permanecíamos assim, percebemos que era ele quem estava, naquele momento, observando a si mesmo e observando a cena que narrava. Havia uma triangulação em sua mente, para onde quer que ele olhasse: para nós, que olhávamos sua relação com essa mulher; para ele, que se observava nessa relação, enquanto nos contava; para ela, que olhava a relação dessa mulher com seu marido e consigo... Assim, após terminado seu relato, despedimo-nos pelo telefone. Tivemos novas notícias de Alex após alguns meses: ele estava bem e iria permanecer no interior por mais alguns anos, morando com seus parentes.

Alex, assim como Édipo, afastou-se da verdade e se aproximou dela num contínuo vai e vem, mas, diferentemente deste, desistiu de procurar por sua verdade a qualquer preço e foi em direção a uma nova ilusão, para que pudesse continuar a se desenvolver por meio daquilo que podia ser criado por ele de modo transgressor. Parece ter criado uma nova ilusão, com ficções, 
com aquilo que estava à sua mão para criar; acabou por formular e criar a possibilidade de observar a cena primária imaginariamente, ficcionalmente, e de situar-se nesse lugar de quem permanece na cena como seu espectador. Pensamos que, assim, Alex deixou de ser Édipo para poder observá-lo, de modo deslocado e imaginário. "A cena primária invisível é povoada apenas por nossa imaginação; é o espaço da ficção" (p. 177), podemos nos recordar, como nos fala Britton (2003), acertadamente.

Assim, não há como não nos lembrarmos de Winnicott (1971/1975) e suas profundas e originais ideias sobre a ilusão e a desilusão:

\begin{abstract}
A adaptação da mãe às necessidades do bebê, quando suficientemente boa, dá a este a ilusão de que existe uma realidade externa correspondente à sua capacidade de criar. Em outras palavras, ocorre uma sobreposição entre o que a mãe supre e o que a criança poderia conceber. [...] A principal tarefa da mãe (após propiciar oportunidade para a ilusão) é a desilusão. Esta é preliminar tarefa do desmame e também continua sendo uma das missões dos pais e dos educadores. Em outras palavras, a questão da ilusão é assunto que concerne inerentemente aos seres humanos e que nenhum indivíduo soluciona de modo final para si mesmo, ainda que uma compreensão teórica dele possa permitir uma solução teórica. Se tudo corre bem neste processo gradativo de desilusão, o palco está pronto para as frustrações que reunimos sob a palavra desmame. (p. 28).
\end{abstract}

Um desmame que, no palco da ficção, mantém-se ocorrendo como um processo interminável, mesmo na mais avançada idade, na forma de esperança e ilusão, na forma de um seio preconcepcional que sempre poderá ser parcialmente realizado e inevitavelmente frustrado... 


\section{A QUATERNIDADE NEGATIVA E O SEU ACONTECIMENTO}

Pensar, em psicanálise, em algo que esteja além dos fenômenos, dos fatos clínicos, parece ser contrário à sua própria atividade. Desde seu início, ela procurou se desenvolver com o propósito de incluir, em seu campo de experiências, aquelas que pareciam sem explicação e que careciam de um sentido que pudesse tanto ser compreensível quanto fazer parte de um método capaz de ser reproduzido: o método psicanalítico. A hipótese do inconsciente, assim, tornou-se uma hipótese por meio da qual foi possível determinado tipo de reprodução sistemática de um procedimento em que não se pretendia alcançar algo inalcançável, mas dar conta daquilo que estava presente e não conseguia ser - justamente - alcançado pela interpretação, ou seja, pela experiência e pela palavra. A experiência desse procedimento fez com que a psicanálise não se tornasse uma filosofia, que poderia simplesmente pensar no inconsciente como algo desvinculado da experiência da consciência e, assim, dividir o nosso universo humano entre aquelas dimensões factuais e inefáveis, entre dimensões divergentes e anômalas - o que realmente não foi o que sucedeu em nossa história.

Bion (1965/2004a), por exemplo, diz-nos:

\footnotetext{
Alguns acreditam conscientemente que o anteparo de ilusão seja uma proteção contra a verdade, essencial para a sobrevivência da humanidade; o restante de nós acredita inconscientemente nisto - mas não menos tenazmente. Mesmo aqueles que consideram esta visão um equívoco, e que a verdade é essencial, consideram que o hiato não pode ser transposto porque a natureza do ser humano impede o conhecimento de algo além dos fenômenos, que não seja conjectura. (p. 157).
}

Com isso, ele nos oferece uma descrição de algo que se encontraria além dos fenômenos, aparentemente dentro de uma tradição kantiana de pensamento; assim, parece ir na 
direção da descrição de uma atividade em que há a ilusão e algo além dos fenômenos, que não é ilusão. Mas seria isso assim mesmo?

Em nosso trabalho, procuramos descrever, em nossos três casos clínicos, a permanência de uma dimensão ontológica, da qual trataremos sistematicamente em seguida, que, embora não esteja presente nas sessões como uma dimensão ôntica da experiência, encontra-se presente na experiência justamente como a presença de uma ausência, da qual parte pode ser pronunciada, mas sobre a qual parece ser fundamental encontrar as palavras ou nomeações adequadas. Não podemos, desse modo, pensá-la simplesmente como dimensão inefável, no sentido de pertencer a algum outro campo da natureza que não seja pertencente ao próprio campo da experiência emocional. O risco de apontarmos para uma dimensão como esta é de descolarmos o ôntico do ontológico, do mesmo modo como podemos querer descolar a consciência do inconsciente, e, assim, tornarmo-nos cada vez mais inaptos para compreender como é a presença do inconsciente na consciência humana ou do Real na experiência psicanalítica.

Quando Bion (1965/2004a) aponta-nos que a natureza humana impede o conhecimento de algo além dos fenômenos, não está, com isso, querendo dizer que é preciso tratar a psicanálise como uma atividade que lidará apenas com ilusões ou fenômenos conscientes. Longe disso, indica-nos que a atividade analítica é de tal radicalidade que pressupõe uma transformação na forma de um tornar-se essa realidade que não pode ser conhecida, ou seja, que essa dimensão, que aparentemente estaria além dos fenômenos, é justamente a dimensão que seria visada pela psicanálise como a realidade na qual o analisando encontraria, na sua possibilidade ainda não tornada para si um si mesmo, um ato positivo de ser. Assim, é preciso considerar que, quando tratarmos do problema do Real nos fatos clínicos psicanalíticos, é preciso ter em mente que estaremos procurando vislumbrar sempre o Real do um ponto de vista de uma dimensão ontológica que, de algum modo, será apreendida na experiência e pela experiência psicanalítica. 
Nas narrativas clínicas que descrevemos, essa dimensão esteve presente como: $\left(1^{\circ}\right)$ os aspectos não desenvolvidos nos relatos dos casos que as narrativas puderam apontar, como distintas "regiões" de "O"; $\left(2^{\circ}\right)$ a presença de uma ausência impossível de ser nomeada; e $\left(3^{\circ}\right)$ a presença de dimensões de ruptura da narrativa, sob a forma de acontecimentos ou visitações inesperados do Real. Todas elas são participantes tanto de uma dimensão ontológica quanto de uma dimensão ôntica e, assim, não podem ser pensadas de modo excludente ou separado, com o risco de destituirmos a psicanálise de ser uma atividade e de estar em uma posição em que se torna possível uma abertura para a participação, na experiência, daquilo que tende a ser recusado no universo cotidiano. Pensamos que a maior radicalidade da psicanálise é justamente a abertura de seu campo da experiência humana, dando a oportunidade para que sobrevenha a tensão inerente à ausência do Real, sempre e justamente quando é possível uma nomeação, e não o seu esquartejamento por caracterizações inefáveis ou inconscientes, que tendem a empobrecer - caso sejam tratadas como excluídas da experiência humana - a potência disruptiva de sua presença.

\subsection{Angústia, Anseio e Alteridade}

No capítulo anterior, descrevemos e discutimos sobre três casos clínicos para podermos observar em que medida sua compreensão poderia se tornar enriquecida se olhada sob o ponto de vista palimpséstico. Nessa perspectiva, nas fendas ou buracos das camadas do palimpsesto das narrativas clínicas, na forma de visitações, o Real estaria presente. Procuraremos, neste capítulo, falar daqueles aspectos da visitação do Real que puderam ser compreendidos como sua própria presença; assim, tornará mais clara a nossa intenção de, paradoxalmente, caracterizar e explicitar aquilo que pode eventualmente ser dito acerca dessa presença que se anuncia por uma 
pura ausência, mas não podemos nos iludir de que, em certa medida, estaremos sempre iludidos, quando falamos sobre algo que se revela como uma experiência.

Isso não deve servir como um pressuposto para que façamos conjecturas sobre aquilo que estaria além da ilusão ou além da experiência; deve servir de referência para uma interrogação sobre aquilo que ilude e aquilo que pode ser um olhar para a tolerância de uma possível desilusão e para a possibilidade de redigir uma escrita sobre certa experiência emocional. Assim, nossa ilusão deve ser confrontada com aquilo que desilude (Winnicott, 1971/1975) e que, desse modo, mostra-se como o possível. Em nossa compreensão, aquilo que desilude não é somente a realidade, com suas vicissitudes, dificuldades e impossibilitadora de plena e completa satisfação do desejo (Freud, 1911/2006s). Aquilo que desilude é, acima de tudo, o próprio Real, com o qual procuraremos mais detidamente nos dedicar agora.

Nosso sentimento de respeito e amor à verdade e ao Real é a base por meio da qual esse trabalho pôde ser escrito ${ }^{34}$. Esse sentimento não se difere daquilo que foi designado por Bion (1967/2000a) como necessidade de verdade pela mente humana. No entanto, sabemos que, embora tenhamos esse respeito por ela, nossas condições para a sua apreensão são precárias e, acima de tudo, alienantes. Como vimos, devemos ter cuidado com a procura pela verdade a qualquer preço, que pode se tornar violência e arrogância sem limites (Bion, 1967/1994d). Caminhamos, na análise, por narrativas que podem nos conduzir para diversos sentidos, alguns interessantes e poéticos, outros empoeirados, obscuros, densos e saturados, tal como palavras repetidas, mas, enquanto caminhamos discursivamente - e também prosseguimos nessa nossa escrita -, vamos, simultaneamente, tornando-nos mais amedrontados, mais cautelosos e mais

\footnotetext{
${ }^{34}$ Amor pela verdade? Mas como poderíamos amar aquilo que nos enche de horror, quando - tolerando-a miramos, mesmo que brevemente, toda a falta e a ausência que ela tem e que conserva em si mesma, como a possibilidade e a impossibilidade de ser dita? Assim, nosso amor pela verdade parece ser simultaneamente um amor pela tolerância dessa falta, pela tolerância dessa impotência de nosso dizer e, ao mesmo tempo, da impossibilidade radical de um dizer que diga o seu todo, mesmo que ela, como alteridade negativa, surja destituindo as experiências comuns e faça parte, portanto, de nosso campo de experiências possíveis. Amar a verdade é, assim, amar essa nossa condição fundamental, a de situarmo-nos em uma posição intermediária, entre o inalcançável da verdade e aquilo que poderia ser, outrora, chamado de verdade. Mas, como amar essa condição tão instável e tão precária da verdade? A resposta a isso não estaria justamente em poder sêe-la?
} 
instáveis. Nossas convicções tornam-se cambiantes, de modo que nada resiste com a força do sentido que outrora teve. Instáveis, permanecemos entre ideias que procuramos resgatar e, assim, torná-las mais claras. Contudo, agora, indo ao encontro delas, observamos que elas recuaram.

Diante de enorme quantidade de material, de livros espalhados, cadernos, folhas, pensamentos, todos disponíveis sobre a mesa de trabalho, vamos lentamente sendo conduzidos justamente para aquilo de que devemos tratar. Entretanto, isso que pressentimos se evade e se retrai. Folheamos os cadernos, buscando alguma explicação; lemos partes selecionadas de livros importantes para nós, mas não encontramos nada que possa, nesse momento, oferecer-nos uma representação que diga aquilo que sentimos ou experimentamos. Certa estranheza diante de nossa escrita, diante das coisas ditas, certa estranheza mantém-nos em uma espécie de quietude inquieta.

Algumas palavras de um texto solto displicentemente diante de nós se destacam e aparecem. Elas dizem: "Entre a realidade bruta, não erotizada, e o cadáver, praticamente nenhuma diferença.” (Giovanetti, 1997, p. 271). Outra frase, ainda no mesmo texto, também pula do papel: "Seu corpo, sempre em vias de fragmentação, é um corpo que se experimenta como uma quantidade infinita de buracos interligados por um fio.” (p. 271). Lemos e relemos vagarosamente e, assim, paramos e imaginamos os fios, associando-os diretamente com os fios da teia da aranha e com os fios do palimpsesto; são todos eles fios esticados com buracos entre eles.

Paramos durante um instante. Ao retornar, lembramo-nos de que começamos interrogando, mesmo que de um modo ainda não explicitado, sobre o que era o buraco dos fios da teia de aranha. Mas permanecemos paralisados, cultivando nossas palavras para que elas pudessem nos alojar naquilo que ainda há de familiar: este texto que escrevemos, certo universo compartilhado que se articula com a compreensibilidade e a sustentação do ser - agora instável. 
Assim, observamos que, ao olharmos os buracos da nossa própria teia, sentimos, na verdade, medo de cair; de cair num profundo, talvez naquilo que seria o não erotizado ou o sem sentido, no mais precário e instável, que não pode ser morada, aonde não podemos habitar e que é somente passagem e vislumbre.

A interrogação sobre o Real sofre, nesse sentido, um duro golpe. Percebemos que sua interrogação não garante que haja uma disponibilidade do próprio Real para ser dito e para se expor. Assim, sofremos também pelo seu silêncio, pelo seu retraimento. Aquilo pelo que interrogamos, desse modo, presentifica-se como o mais fugitivo, o mais arredio, o mais precário, porém tão disruptivo, por ser e simultaneamente nada ser, que não se deixa apreender senão por sua característica de permanecer sempre escapando.

Algum tempo em silêncio passa; percebemos, no silêncio, que não é apenas o Real que se retrai, mas as coisas. Temos o pressentimento de que uma pura diferença, que não necessariamente está nas coisas, parece existir independentemente. O Real parece permanecer quando o restante evade-se, mas é muito incômodo permanecer nessa situação; não nos sentimos dispostos a manter isso por muito tempo. É incômodo porque nós mesmos nos parecemos com um outro em quem nós somos. Mas incômodo não é a palavra exata; não sabemos se poderíamos dar uma palavra exata para isso, mas aquela que melhor representaria isso, nesse instante, é angústia.

Nessa angústia, não podemos permanecer, senão por breves instantes; logo somos movimentados por certos anseios que nos reconduzem às coisas do mundo. Voltamos aos cadernos, aos livros, à compreensão e organização. Somos novamente filhos e também pais; temos nossa casa, nossa terra e nossos objetos; somos ainda casados e temos amigos; assim, não somos sós. No entanto, tudo ainda permanece estranho, diferente. Um certo vento sopra lá fora e o sol, que colore a parede amarela, deixa-a quase inteiramente branca por sua luz. Sentimos ensejo por poesia, por poetizar. O vento parece vir de longe, dos buracos da teia. Não somos 
apenas filhos de alguém; assim, reconhecemos tanto nossa filiação quanto nossa orfandade, pois somos inevitavelmente órfãos, ainda que de pai vivo. Permanecemos sós; amigos, companheiros, pais, mas essencialmente sós.

Após isso, algumas ideias aparecem em nossa mente, espontaneamente, sem que tenhamos ido ao encontro delas. Elas parecem querer somente aparecer, para serem substituídas por outras associativamente. Deixamos que elas tenham seu motivo de ser; permitimos sua aparição não criteriosa, algo como uma livre associação. Pensamos na noção de desamparo em Freud (1926/2006m): dependência absoluta da criança ao outro, para que possa satisfazer-se e ter seus anseios primordiais atendidos narcisicamente. Enquanto pensamos nisso, a ideia do cadáver não erotizado passa lentamente por nossos pensamentos. Pensamos também em Bion (1962/1991b) e em sua ideia de preconcepção do seio, da preconcepção a priori do seio da mãe. Pensamos, no entanto, que, se o bebê nasce ainda em uma tessitura frágil, em uma teia frágil, e sua angústia diante do Real é sua condição mais originária, então a preconcepção do seio parece ser o "anseio por" pessoas, paternidade, terra e coisas, e por tudo aquilo que se concentra primordialmente no seio materno. Algumas noções puderam, com essa experiência emocional, ser apreendidas sobre nosso modo de vislumbrar o acontecimento do Real: ele $\left(1^{\circ}\right)$ permite o surgimento da alteridade/diferença; $\left(2^{\circ}\right)$ ocorre como anseio; e $\left(3^{\circ}\right)$ acontece como destituição de sentido.

Dizer que há um acontecimento é dizer que esse Real existe, é existente. No entanto, embora seja real, não podemos dizer que sua existência seja uma existência como a dos entes, pois ele não é nem uma pessoa nem uma coisa, ou seja, não é ente. Não se trata também de um ente imaginário, do qual se pode falar tudo aquilo que se quer, sem que se precise ter uma confrontação na experiência dos sentidos, pois, do mesmo modo, seria um ente, apreensível por uma definição e qualificado por um predicativo. Assim, o Real assume uma existência peculiar, pois existe como uma realidade que não se apresenta e isso quer dizer que é simultaneamente 
inexistente, ou seja, o Real tem um atributo negativo em comparação com o ente, que tem atribuição positiva. Positivo é dizer que determinado ente é; por exemplo, ao dizer que uma rosa é (vermelha). O Real não se deixa capturar por uma definição ou por uma representação. Pensamos, portanto, em uma característica negativa para o Real, ou seja, um sinal de que seu aparecimento ocorre quando a alteridade/diferença presentifica-se no ente.

Essa alteridade/diferença manifesta-se quando aquilo que se tem como conhecido evadese ou se retrai e não é ocupado ou saturado por nenhuma representação, ou seja, como uma desconstrução do conceito, uma desconstrução do conhecido ou uma impossibilidade de estabelecimento de um sentido de verdade representacional. Essa alteridade manifesta-se nos entes quando o sentido outrora atribuído retira-se. Essa retirada do sentido torna-se, também, a possibilidade para a manifestação da diferença e, com ela, da surpresa e da perplexidade diante de algo - do Real - que se anuncia por meio de um dizer muito peculiar, que faz aparecer o ente também como uma palavra impressa de enigma, multiplicidade e questão.

O Real aparece como anseio, produto da necessidade, com o pressentimento da falta de contornos diante da possibilidade de queda sem fim naquilo que parece ser o seu abismo, seu espaço vazio ou seu escuro. $\mathrm{O}$ anseio parece ser a tentativa de constituir os contornos do mundo pessoal, ou melhor, as bordas do horizonte do aparecimento daqueles aspectos da existência humana que são necessários: terra, paternidade, pessoas e coisas. Safra (2007) descreve a necessidade como um saber originário sobre a própria condição existencial e, dessa maneira, sobre o próprio Real, que surge para além da biografia, como um saber sobre algo que é fundamento da origem da organização mental. Na necessidade, há o anseio pelo outro, fundamentalmente como uma necessidade do outro.

Podemos também aceitar inteiramente a tese de Safra (2007) quando ele diz que essa necessidade, que tende ao infinito, pode ser caracterizada mais propriamente como uma necessidade de entes, uma necessidade de lugar, uma necessidade de paternidade e uma 
necessidade de outros. Assim, podemos prosseguir dizendo que o Real acontece como necessidade, por meio da solidão originária, do nada, do desterro e da orfandade. Tal como considerado pelo autor, são facetas preexistentes da condição humana; elas preexistem porque são preconcepcionais. Assim como o nada move o homem que anseia, num anseio sem fim, os entes, a solidão originária move o homem, num anseio também sem fim, em direção aos outros. O desterro move o homem como um anseio por lugar e a orfandade move o homem como um anseio permanente por paternidade. Nenhum desses anseios deixa de ser anseio na vida de uma pessoa. A inquietude do anseio ocorre pelo pressentimento da negatividade do Real e seu movimento dá-se pela impossibilidade de ela ser aquietada por uma biografia, uma vez que corresponde justamente ao pressentimento daquilo que está do lado de "fora" de nossa biografia.

A fugaz apreensão desse Real negativo ocorre quando suportamos permanecer inquietos e não familiarizados com as coisas familiares. Nesse sentido, podemos pensar que a alteridade/diferença e a necessidade aparecem conjuntamente quando o anseio pelo outro faz justamente com que aquilo que já existe como outro seja retraído e tenha seu sentido desfeito; uma destituição de sentido, que faz algo se revelar como surpreendente, não porque é expressão da alteridade/diferença, mas porque tem o aspecto de algo cujo sentido prévio desmoronou. Para a clínica psicanalítica, a possibilidade desse desmoronamento do sentido é tanto a expressão de continência da falta de sentido quanto uma condição fundamental para que a mente do analista possa permanecer não saturada com aqueles elementos que a memória, o desejo e a compreensão fornecem (Bion, 1967/2000a), muito embora saibamos que sustentar tal disposição é uma condição usualmente das mais difíceis.

O anseio que surge no vislumbre do Real conduz-nos em direção ao outro, às coisas, aos pais e a um lugar, em um pressentimento por cada uma dessas necessidades, o qual é também uma abertura para algum modo de saturação do psiquismo que, até então, estava aberto na 
apreensão angustiante do Real. O anseio cria um pressentimento que é uma tendência a saturar um elemento "vazio", uma não coisa (no-thing) ${ }^{35}$, em uma representação, emoção, ente, ou seja, em uma "coisa" humana.

“A psicanálise lida com objetos que incluem a relação da não-coisa com a coisa. A personalidade capaz de tolerar a não-coisa pode usar a não-coisa, e assim é capaz de usar aquilo que podemos agora chamar de pensamentos.” (Bion, 1965/2004a, p. 121). Nessa passagem, o autor indica que a tolerância a esse estado não saturado na mente, a esse estado que parece ser tão próximo a um nada, com uma ausência de coisas, de entes, fornece-nos a possibilidade para apreendermos o pensamento sob a forma de um pensar. Bion (1967/2000a) enfatiza, também, a tese de que o analista, na sessão, deve se manter livre de memória, desejo e compreensão, tal como uma folha de papel em branco, completamente insaturada, mas com uma preconcepção, para que possa se tornar saturado com aqueles elementos trazidos pelo paciente durante a sessão.

Esse estado de mente a que o autor refere-se parece ser análogo àquele que designando como o que apreende o Real, ou seja, o de permanecer insaturado, mas sendo escrito a partir de determinadas possibilidades de escrita. Bion (1967/2000a), empregando uma terminologia utilizada pelo poeta inglês John Keats, designa como capacidade negativa essa capacidade de tolerar um estado de incerteza, insegurança e incompreensão (Lopez-Corvo, 2003). O saber sobre o Real, que se difere de um conhecer sobre o Real, não é um saber que se estabelece em virtude de um conhecimento, mas de uma experiência, que não está fundada, paradoxalmente, na biografia da pessoa, mas naquilo que há de marginal ou do lado de "fora" da biografia de alguém; ou, como nos diz Pessanha (2000):

\footnotetext{
${ }^{35}$ No inglês, tal como foi usada por Bion (1965/2004a), essa palavra descreve tanto o sentido de no-thing, ou seja, de não coisa, quanto o sentido de nothing, ou seja, de nada. Parece-nos que o autor pensava no uso de ambos os sentidos simultaneamente.
} 
Como não acredito que o amigamento do Fora possa ser ensinado, 'desconfio' um pouco de um preceito técnico meta-técnico que deliberasse acerca da manutenção do desconhecido como receita para evitar o uso fetichista e objetivante da teoria. Penso, com Heidegger, que a experiência que revela o caráter intrinsecamente sintomático de toda teoria não é uma experiência ensinável; ela acontece ou não. (p. 92).

Assim, podemos pensar que, embora Bion (1967/2000a) possa recomendar o abandono de toda memória, desejo e compreensão para o trabalho analítico, isso apenas se refere a um estado próximo ou equivalente àquele do "amigamento" do "fora". Esse "amigamento" não é algo que possa ser ensinado, pois se trata de uma experiência que surge em virtude de uma disposição e de uma disponibilidade. Essa fala de Bion (1967/2000a) parece ser, portanto, uma recomendação, tal como Freud (1912/2006i) escreveu em Recomendação aos médicos que exercem a psicanálise. Entretanto, também não podemos dizer que é a disponibilidade que produz tal experiência, pois, com isso, poderíamos tentar criar um mecanismo técnico para a produção da disponibilidade, o que nos parece um artifício incompatível com a gratuidade da experiência.

Se tal experiência indica um ultrapassamento transcendente em relação às coisas, então esse ultrapassamento libertador, essa transcendência, "não significa apropriação do que é, mas o seu respeito.” (Levinas, 1980/1988, p. 282). A verdade, vislumbre desse ultrapassamento transcendente, não pode ser compreendida como apropriar-se de algum conteúdo ou representação, mas como respeito pelo ser, que significa manter-se em concordância com aquilo que dele se desvela e, assim, com a gratidão por sua manifestação, primordialmente quando ela se torna uma existência.

Assumir essa posição transcendente, amigar-se do Real, não é se deixar dissimular por aquilo que costumeiramente chamamos realidade, em suas perspectivas ônticas e determinadas (Grotstein, 2010). A posição transcendente bioniana, conforme compreende Grotstein (2010) e tal como descrevemos neste trabalho, é uma tentativa de posicionar o pensamento bioniano em 
uma perspectiva ontológica. Para esse autor, a meta intrínseca da psicanálise seria ajudar o analisando a transcender os véus de ilusão que se interpõem entre ele e o Real; e, por Real, ele quer dizer "O”.

Essa ajuda pela posição transcendente certamente fará sentido se pudermos compreender o analista como uma pessoa que pode se manter nessa posição. Nas palavras de Bion (1970/1991a), que citamos a seguir, observamos que somente nessa posição o analista estaria apto para poder interpretar:

Quanto mais suas interpretações possam ser julgadas como demonstrando como seu conhecimento, sua experiência, seu caráter são necessários para formular aquele pensamento daquela maneira que foi formulado, mais razão existirá para supor que a interpretação é psicanaliticamente inútil, alheia ao âmbito O. (p. 105).

É no posicionamento transcendente, numa amizade com o Real, que se torna possível para o analista ouvir as associações do seu paciente livremente, sem memória, desejo e compreensões anteriores. Quando as interpretações estão marcadas pela pessoalidade do caráter do analista, pela sua experiência de vida ou por aquelas determinações próprias da sua biografia, isso se refletirá diretamente naquilo que será dito. Parece que, nessa passagem, Bion (1970/1991a) convida-nos a tolerarmos a não coisa ou os buracos da teia ou, ainda, conforme estamos utilizando neste trabalho, o Real, para que, por meio dessa capacidade de tolerância, que é, paradoxalmente, um afastamento dos entes, possa surgir um ato positivo de ser (Bion, 1965/2004a), um ser "sendo", acontecendo gratuitamente e despretensiosamente, como uma dádiva ou uma doação inesperada para a personalidade amadurecida.

\subsection{A Quaternidade Negativa do Real}


Iremos, neste momento, procurar sistematizar e descrever os acontecimentos descritos como sendo de visitação do Real nas narrativas clínicas desenvolvidas neste trabalho: $o$ nada, $o$ desterro, a orfandade e a solidão essencial. Essas visitações, por sua vez, também podem ser apreendidas quando o analista está amigado com sua posição transcendente, tolerante a um estado de puro anseio, necessidade e abertura à inospitalidade do Real.

1. O Nada. A contraparte dos entes, dos fenômenos e das representações imaginativas é a sua ausência. O nada, ausência do ente, é a negação deste quando dele emerge sua contraparte. O nada, que pode ser descrito também como não coisa, é aquilo que fundamenta a aparição do ente em sua diferença, aquilo que faz com que possamos sempre nos referir ao ente como diferente daquele que já foi. O nada surge como uma preconcepção de coisas, justamente porque essa preconcepção indica a necessidade inerente do ser humano de estar com coisas no mundo. Assim, por meio do impacto do nada, formula a aparição do fruto de sua necessidade.

A necessidade de coisas é aquilo que move o ser humano em direção ao encontro com as coisas do mundo formuladas, criadas como aquilo que podia ser criado, e isso se dá justamente a partir de sua apreensão inicial da ausência das coisas, da não coisa ou do nada originário e fundador do anseio. Se, por um lado, podemos dizer que há uma preconcepção das coisas, por outro, essa preconcepção ocorre não pelo encontro com as coisas, mas pelo encontro com a não coisa, que será pressentida de um modo ou de outro ao longo da vida. O anseio por coisas é, assim, o prenúncio da aparição das coisas, quando o homem vislumbra a face do nada.

2. O Desterro. O sentimento de estar enraizado na própria terra tem também sua contraparte fundamental: o desterro, que indica a condição originária do ser humano de ser primordialmente sem-terra, sem pátria, sem origem, sem região, portanto um estrangeiro da familiaridade; mas também de ser sem ethos, sem costume e sem morada humana. Todos os significados ônticos relativos à pátria e ao lugar de origem são posteriores e derivados do encontro com aquele que não se encontra em parte alguma, mas que clama por ter uma terra e 
um recesso seguro. O anseio por terra, por pátria, por lugar e por ethos decorre dessa apreensão originária de não se ter um lugar e de não se ter raízes com determinada terra. Assim, o desterro é aquela face do Real que indica uma instabilidade do ser associada à errância, ao estrangeirismo e à impossibilidade de encontrar-se definitivamente em uma pátria ou região, sem que o anseio por terra ou lugar permaneça ainda como anseio.

Todo homem é estrangeiro nesta terra, por mais que tenha fincado suas raízes naquela paragem a que chama terra de seus ancestrais. Seu estrangeirismo decorre não do fato de ter uma terra em algum outro lugar, mas de estar sempre instável e indo de volta àquele lugar que fantasia ser sua própria morada, ainda que esse anseio nunca se esgote. As raízes do enraizamento, nesse sentido, jamais serão suficientemente fundas para segurar-nos na terra da instabilidade de nosso movimento, de nosso devir, que nasce da precária condição de ser semterra e faz com que, a cada instante, sejamos levados a ter que refundar uma nova pátria, uma nova casa, uma outra terra, que seja tanto o lugar da ancestralidade quanto o lugar do nascimento daquilo que ainda não pode ser pensado, como a terra que possibilitará o nascimento dos não nascidos.

Terra significa também ethos, ou seja, a casa do homem. Nesse espaço seguro, que se faz morada para o homem, poderão se inscrever os costumes, os hábitos e os valores humanos. No entanto, o ethos, esse lugar de estada segura para o florescimento do ser do homem (que também é designado como morada dos animais em geral), não estaria finalizado enquanto tal. A sua forma é inacabada e esse inacabamento poderia ser explicado como a exigência inerente de algo que pede a sua finalização, como tarefa humana infinitamente distante (Vaz, 1993).

3. A Solidão Essencial ou Originária. Quando Winnicott (1958/1982a) afirma não existir alguma coisa como um bebê, ele nos oferece uma indicação sobre a necessidade, para o recém-nascido humano, de ter inicialmente contato ou relação com outro humano para fazer dele um bebê. Um bebê, assim, só faz sentido de existir se for junto a outro que a ele se 
dedique. Essa remissão direta do bebê ao outro indica que aquilo que nasce sob a forma humana não permanece só, em solidão, pois, nessa permanência, não haveria sequer uma nomeação. A solidão originária deve, portanto, assim como as outras faces do Real, ser encoberta pelo movimento em direção aos outros que oferecem um sentimento de presença, associado com a realização de algo que estava lá para ser realizado (criado). No entanto, a solidão essencial, originária, permanece como aquela presença do Real que move o homem em direção aos outros, permanecendo com os outros como referência, mesmo quando alguém esteja fundamentalmente só.

O outro, que não é apenas uma pessoa, mas é o próprio elemento constitutivo da pessoalidade, aparece sempre como a referência que possibilita que a experiência de solidão seja vivida como uma instabilidade sustentada. A solidão originária, que nos conduz em direção aos outros, remete-nos, assim, à nossa própria “outrossidade", ou seja, ao outro que somos nós, o outro em nós que profundamente ansiamos por ser, por nosso contínuo pressentimento de nossa falta de ser. Por isso, torna-se compreensivo quando Winnicott (1958/1982a) afirma que a capacidade de estar só depende fundamentalmente do paradoxo de se estar primordialmente só na presença de alguém. A solidão essencial originária é aquela solidão que move os homens para estarem num contínuo anseio pelo outro e que faz com que toda existência - em si mesmo ou dos outros - seja ansiada e próxima. Heidegger (1934, citado por Safra, 2004) mostra-nos isso em uma bela passagem sobre estar em solidão em sua casa em Todtnauberg, no coração da Floresta Negra:

As pessoas da cidade se admiram com freqüência deste isolar-se longo e monótono entre os camponeses e as montanhas. E, no entanto, não se trata de um mero isolamento. Trata-se de solidão. Em verdade, nas grandes cidades, o homem consegue isolar-se, como mal chega a fazer em qualquer outro lugar. Mas lá em cima nunca é possível isolar-se. Pois a solidão traz consigo a força primigênia que não nos isola, mas lança toda a existência na proximidade profunda com todas as coisas. (p. 49). 
4. A Orfandade. Todos nascemos e permanecemos órfãos ao longo da vida. Nossa orfandade é a origem por meio da qual ansiamos ter paternidade. O bebê vive na inospitalidade de sua origem, assim anseia pela hospitalidade que a paternidade poderá lhe ofertar. A devoção materna tem como pano de fundo o desencontro entre mãe e filho, o desconhecimento de um sobre o outro e a atribuição de filiação para alguém que está somente mergulhado na própria orfandade. No entanto, ser órfão não significa ser alguém que tinha uma paternidade e a perdeu, mas ser alguém que não tem paternidade fundamentalmente desde o início da vida; trata-se de uma atribuição negativa. A paternidade, oposto da orfandade, é a sua contraparte e apenas pode ser compreendida por meio do anseio do bebê de ter o acolhimento hospitaleiro e receptivo que essa devoção de uma mãe pode oferecer.

Esses quatro acontecimentos descritos como visitações do Real podem, também, ser descritos como inexistentes; isso se deve ao fato de que não se tratam absolutamente de figuras ou de representações ônticas. Por não se tratarem de entificações, as quatro visitações do Real são caracterizações ontológicas do Real, ou seja, de um registro absolutamente distinto da descrição de qualidades, de predicativos complementares a "ser". Trata-se da caracterização negativa do existir humano, ou de um fundamento sem fundamento, de uma origem na qual a orfandade, a solidão, o desterro e o nada são conjuntamente as características fundamentais e inexistentes do universo ôntico. As visitações são, assim, acontecimentos de destituição subjetiva do eu mesmo e de seu universo ôntico cotidiano, ao mesmo tempo que produzem o anseio por sua contraparte e por sua saturação.

\subsection{Nas Bordas do Dentro e do Fora}


O trabalho analítico pode apreender o movimento que existe entre a visitação do Real e o seu esquecimento nas sessões. Há um movimento, nas situações clínicas apresentadas, que demonstra como o Real estava presente e a sua presença, embora temida e afastada, era paradoxalmente a fonte de uma questão que estava sendo constantemente respondida, sem conseguir ser alienada por uma resposta definitiva. Isso equivale dizer, como Blanchot (citado por Bion, 1963/2004b) afirma, que a resposta adoece e destrói a questão, porque, em seu processo significador, pode retirar da pergunta justamente aquilo que há de abertura ao novo e ao seu transcendente negativo. Podemos também, dentro de outro ponto de vista, escutar aquilo que nos diz Safransky (2000):

Mas a força do numinoso não desapareceu. Ela brota do singular movimento entre nada e algo, que o ser humano pode executar [...] Esse é seu espaço numinoso que lhe permite vivenciar como milagre - o milagre de sequer existir alguma coisa. E não apenas isso - igualmente espantoso é nesse pano de fundo a potência criativa do ser humano: ele pode produzir alguma coisa [...] Através da angústia podemos vir ao mundo outra vez. (p. 222).

Esse movimento transcendente - entre nada e algo -, que implica, na análise, manter uma atitude de paciência ou de serenidade, significa que o analista mantém-se na instabilidade das bordas ou das fronteiras entre o Real (ontológico) e os fenômenos (ônticos) da experiência existente, ou seja, na própria diferença ontológica. É somente nessa fronteira, nesse "entre”, que podemos, como analistas, presenciar o aparecimento do universo ôntico como participante daquela dimensão ontológica que não se deixa capturar por formas simbólicas ou representacionais; podemos, assim, vislumbrar aquela dimensão ôntica que estranhamente não se permite ser inteiramente representada e compreendida. Trata-se de uma fronteira difícil de ser demarcada e que não pode ser definida claramente. No entanto, é a fronteira que nos caracteriza como seres que somos, constantemente flertados por regiões impossíveis para nós, e nos mantém nesse movimento descrito por Safransky (2000). Essas regiões ou territórios 
impossíveis, em sua oposição, mantêm-nos com a possibilidade de estar, na instabilidade, revendo esse lugar possível para nós: a fronteira.

Se, por meio da angústia, podemos vir ao mundo outra vez, é porque precisamos e temos que existir neste mundo da melhor forma possível e isso significa sermos capazes de testemunhar no existente uma transfiguração que coloca o mundo em devir, num devir da fugacidade e da transitoriedade de cada experiência emocional. É por meio dessa impermanência e fugacidade que as experiências clínicas e humanas podem estar libertas de sua prisão luminosa da significação e compreensibilidade imediatas, mas esse desabrigo precisa sempre ser abrigado, pois somente por meio de seu acolhimento podemos dar voz e lugar para aquilo que não tem nem voz nem lugar. Desse modo, não podemos nos esquecer de que permanecer nas bordas ou na fronteira de nosso universo não significa cultuar o Real como morada ou como horizonte de chegada. Pessanha (2000) já havia compreendido isso na seguinte passagem:

Se por um lado é necessário trazer o homem de Dentro para a proximidade do Fora, por outro, e Heidegger se esqueceu disso, é preciso também trazer aquele que permaneceu Fora até a proximidade do Dentro, facultando-lhe a possibilidade de encontrar os outros, as coisas, e de permanecer no aberto do mundo. (p. 108-109).

As experiências clínicas que procuramos descrever anteriormente, nesse ponto de vista, foram expressões de encontros e de desencontros com aspectos ou visitações do Real. O caminho para a apreensão desses aspectos negativos foi o caminho de uma psicanálise que se manteve como um espaço de disponibilidade para a instabilidade do ser, aberto à experiência emocional de disrupção e estranhamento. Esse espaço de disponibilidade, no entanto, parecia sofrer constantes revezes nas sessões, ao se tornar frequentemente um lugar de amparo, acolhimento e resposta. Entretanto, no processo de tolerância à instabilidade, por vezes pudemos revelar a necessidade que os pacientes tinham de lugar, de coisas, de pessoas, de 
paternidade e, portanto, de respostas. Podemos dizer que uma resposta ou uma compreensão sobre determinado assunto também promovia um aparente silenciamento do desassossego e da instabilidade do ser.

Pudemos perceber, também, a necessidade de entificação: os pacientes necessitavam de sustentação e apego a uma realidade compartilhada e obtinham isso representando e significando suas situações com os recursos que tinham à mão, recursos culturais que eram, também, formas prontas de se pensar. Diante de situações assim - demasiado humanas -, achamos que a nossa posição precisou ser constantemente revista e reorientada, pois, somente permanecendo receptivos à instabilidade, posicionados nas bordas de toda teoria, de toda explicação, de toda entificação e, principalmente, de nossas necessidades pessoais, podíamos encontrar aquela situação trazida pelo paciente não apenas como nova e original, mas transmitindo, de algum modo ainda pouco claro, a possibilidade de estar amigada com o desabrigo da falta de sentido preexistente, para que o "fora" pudesse também caminhar até a proximidade do "dentro".

Pensamos que essa comunicação não explícita, silenciosa e postural pôde ser, na verdade, a abertura para determinados fatos clínicos que desmontavam, por meio da heterogeneidade, certas certezas e teorias pessoais. Sabemos, no entanto, que aquilo que aparecia como conhecimento do paciente sobre si mesmo não era, portanto, novo, mas um conhecimento antigo sobre essa precária condição humana, que era relembrado como um saber; um saber que não se sabia saber. Diante dessa precariedade, as histórias podiam ser recontadas e ser, também, reposicionados a biografia e os sintomas pessoais. Havia, assim, uma clínica que testemunhava a ausência, sem uma preocupação prévia em criar algo que devesse ser introduzido nessa ausência.

Verificamos que, quando tolerávamos os espaços vazios e ausentes, sustentando a necessidade dos analisandos, sem que precisássemos introduzir representações que 
tamponassem os buracos, esse elemento vazado podia ser mais bem tolerado. Corria-se menos o risco, assim, de ele se tornar um objeto maligno ou de ser fantasiado como uma ausência que abrigava uma negatividade malévola. Nesse sentido, Bion (1967/2000a) chama-nos a atenção para o fato de que, em face de uma preconcepção não realizada, pode surgir a frustração e com ela, quando não tolerada, um objeto mau, que é justamente aquele objeto frustrante sob sua forma maligna, ou melhor, aquela não coisa intolerável, que surge representada como um objeto mau.

O importante a ressaltar, no entanto, é que tanto o Real parece ser aquele inóspito em que é impossível permanecer - como o "fora" da condição humana - quanto o puro ente, desprovido de buracos, possibilidades e diferença - como o "dentro" da experiência - também é inabitável. As bordas são margens que situam o homem no lugar de sua oposição, no "entre" mundos, entre cada um desses extremos, desses impossíveis.

\subsection{Real, Acontecimento e Alteridade}

Figueiredo (1994), em seu livro Escutar, recordar, dizer, desbrava um caminho retilíneo para o desvelamento das visitações do Real, por meio de uma revisão da noção de acontecimento. Para o autor, um acontecimento é uma ruptura na trama de representações e no tecido de realidade para a transição para um novo sistema representacional; ainda, destroça o mundo, a própria realidade, dando origem à possibilidade de novas possibilidades, um "mais além do possível” (p. 153). No acontecimento, o que irrompe é o Real e o que se destroçaria seria a realidade, como aquela trama de significações medianas e familiares em que estão, em um primeiro momento, suprimidas a estranheza e a surpresa do ente. Embora o autor prefira usar o termo 'Real' em letra minúscula, achamos que a letra maiúscula, tal como usamos neste trabalho, tem a função, como já propomos anteriormente, de diferenciá-lo de um real que 
frequentemente está associado à predicação de realidades ônticas, como verbo predicativo ou como substantivo masculino que também não atinge a proposta do autor.

O Real, ainda segundo Figueiredo (1994), é o acontecimento como irrupção do inesperado, que se entremostra apenas como enigma, implicando simultaneamente excesso de questão e vazio de sentido. $\mathrm{O}$ autor ainda afirma que o Real demanda tradução, muito embora não exista algo previamente que demande ser traduzido, ou seja, o Real demanda respostas metaforizantes aos seus enigmas. Pensamos que tais colocações ajudam-nos a descrever nosso próprio ponto de vista, pois, se o Real destroça a realidade, como uma ruptura naquilo que existia de trama de significados preexistentes, então, como esse inesperado, é ele mesmo o desencadeador de uma demanda por sentido, que anseia produzir sentido, enquanto o inesperado é justamente o estado de abertura proveniente do desfazimento do sentido das significações preexistentes. Nesse sentido, podemos ainda dizer que é próprio do Real, como acontecimento, irromper como inesperado, porque é o inesperado a própria alteridade, a diferença, o outro que aparece na face do mesmo.

Parece-nos que a apresentação de Figueiredo (1994) corrobora nossa tese de que o Real tem seu aparecimento também como alteridade/diferença, uma vez que ele aparece destruindo "o tecido dos fatos e experiências compossíveis e, essencialmente, não surpreendentes." (p. 156). Temos, na passagem do vislumbre de Édipo de sua condição de assassino do pai e esposo da mãe, a emergência radical desse aparecimento do Real, como anseio ou demanda por tradução, diante do assombro do destroçamento da realidade pela diferença/alteridade. As respostas possíveis não podem ser, no entanto, respostas, mas apenas precárias figurações do enigma que foi colocado, um enigma que fora - pouco tempo antes - pela Esfinge apresentado e destruído, na forma de uma resposta, por Édipo. Nesse sentido, podemos dizer que o destroçamento da realidade ocorre pelo aparecimento de uma irrupção da alteridade inesperada no mesmo daquela trama de significados e experiências que costumeiramente designamos como 
realidade ou realidade compartilhada; há, nessa irrupção, a destruição da realidade pela destituição do sentido que havia nesta.

Voltamos a pensar, agora, no estatuto da realidade quando rompida ou destroçada pela irrupção do Real. Quando Figueiredo (1994) afirma que ela demanda tradução, quer dizer com isso que a tradução faria transitar certo existente (o Real) por meio das palavras. O enigma do Real, para não ter um efeito perturbador, traumático e atordoante, precisa ser transportado por meio das palavras, de modo que elas possam expressar a existência do Real em trânsito, por meio de palavras que abriguem esse existente. Há, aqui, uma aproximação entre o Real e a noção levinasiana de "há" da existência que ainda não se tornou existente ou daquilo que é o possível; seriam palavras quebradas ou palavras abertas. Pensamos que essa possibilidade encontra-se esquecida em uma época em que as palavras têm o propósito de designar especialmente coisas produzidas, conceitos ou situações definidas, como instrumentos de nomeação. Parece que vivemos em uma época em que o mistério daquilo que aparece deve ser definido e classificado para, quem sabe, ser vendido no comércio como a última novidade, com um nome ou proposição imprópria, pois essas palavras abertas, diferentemente, têm a função de abrir e apontar o sentido do Real por meio delas e para além delas mesmas, tal como um ícone, e de ser a direção, o apontamento ou o guia para um mais além, para que o sentido dado revelese como além do significado da frase; são, no entanto, frágeis demais para se tornarem produto de exploração comercial.

Essa palavra aberta indica o sentido do aparecimento desse Real, como a irrupção de um sentir ou de uma sensação da presença de uma diferença que clama ou necessita de paternidade, terra, coisas ou pessoas. Pessanha (2000) também diz-nos algo sobre a palavra quebrada: “O escondido e o indizível devem aflorar junto da palavra, devem finitizar e arrebentar a palavra dentro dela mesma. A palavra quebrada, ao nomear a presença das coisas, aponta para além delas mesmas, aponta para o mistério da aparição.” (p. 119). Assim, procuramos dizer que, 
embora o Real não possa e não deva ser definido, ordenado, classificado e sistematizado segundo certo critério, ele pode transbordar das palavras, quando elas se rompem, apontando sua direção, seu buraco, sua fenda.

Na clínica psicanalítica, sabemos que há uma grande diferença entre darmos um significado sobre um conflito emocional para algum paciente, como um significado pronto e que já estava à nossa disposição por meio de conhecimentos prévios que foram aprendidos, e a possibilidade de se encontrar um significado - às vezes, esse mesmo significado - emergindo de uma descoberta da situação analítica, marcada pela irrupção da alteridade/diferença. A diferença entre ambos, de modo geral, é que o segundo conserva o frescor daquela irrupção que traz a verdade e o primeiro pode até ter o mesmo conteúdo, mas se impõe como significado e tampona o caminho do desvelamento e da criação da palavra esburacada.

Isso nos leva a pensar, tal como apontou Ogden (1996a), que a análise não significa apenas que o analisando fale tudo aquilo que lhe vier à mente no percurso de uma sessão, mas que ambos, o analisando e o analista, precisam estar livres para se comunicar na forma de palavras ou de sensações, consigo mesmo e com o outro. Desse modo, aquilo que deve aparecer no decurso de uma análise não será o significado que deseja se impor como verdade preexistente, "tamponadora", herança de uma tradição, mas aquela conquista mútua, de um dizer que almeja a liberdade e, para isso, procura encontrar as amarras das repetições e das determinações prévias inconscientes para que, durante o processo analítico, seja pensado aquilo que jamais pôde ser pensado, dito ou sentido. Pensamos que isso ocorre quando as palavras podem, inclusive, pressentir certo limite próprio delas mesmas, ou seja, quando elas se tornam veículo de algo que pode acontecer no interior delas mesmas; e, quem sabe, revelar que algo estará ocorrendo além delas mesmas, mas que somente por meio delas poderá acontecer.

O Real que deve transitar nas palavras é possível pela tolerância com a transitoriedade do sentido da experiência emocional. O acontecimento que nos aponta Figueiredo (1994) é 
ruptura e transição, ou seja, o inesperado, o surpreendente, aquilo que ainda não pode ser pensado na situação analítica é possível quando podemos nos manter abertos para o(s) próprio(s) acontecimento(s) da sessão. A transitoriedade rompe com a noção de realidade quando põe em devir tudo aquilo que é conhecido, que está disponível para ser pensado de antemão. A possibilidade de tolerarmos esse estado de acontecimento analítico, de tolerar e sustentar o acontecimento que está ocorrendo, ao manter as palavras e os sentidos em trânsito, fornece-nos a chave para a abertura ao Real, que deve veicular-se naquele ponto em que as palavras não se sustentam mais, em que há um transbordamento nas palavras para os enigmas da alteridade, que são pressentidos como verdade em nós.

As experiências analíticas são transitórias, mas nem sempre fugazes. Muitas vezes, elas podem, em sua transitoriedade, revelar-nos aquilo que até então não era sentido como nossa própria verdade. No entanto, no instante em que se sente essa verdade, ela também se coloca em trânsito, mas isso não quer dizer que não possamos retê-la e guardar algo da experiência emocional que tivemos diante de tal impacto ou irrupção da verdade; ou, como nos diz Alves (1997):

À transitoriedade da experiência, seguem-se momentos de dispersão; pode-se dizer que a experiência faz-se e desfaz-se; é uma experiência real e pessoal que se diferencia da comum. Estas experiências interiores, pela ação da função $\alpha$, transformam-se em material que é armazenado e condizente com a instalação de uma memória inconsciente, tornando-se parte do processo mental de crescimento. (p. 248).

Temos, assim, como propósito colocar a questão sobre a possibilidade de pensarmos sobre o modo como poderiam ser armazenadas nossas experiências com o Real. Sabemos, no entanto, que não responderemos a esse enigma e deixaremos essa questão, por ora, aberta; o que apenas queremos destacar é a possibilidade de que, diante de um acontecimento analítico, da irrupção do acontecer do Real, que desfaz a realidade conhecida e a destitui pela 
alteridade/diferença, talvez algo possa ser mantido como uma experiência armazenada e participante da ampliação da noção do eu mesmo. Parece, assim, que o crescimento psíquico decorre do fato de armazenarmos não apenas conteúdos anteriormente impensáveis, mas a própria noção de que o nosso eu mesmo torna-se alteridade/diferença, que nos põe constantemente em interrogação acerca da realidade conhecida por nós. O armazenamento da experiência do Real seria, portanto, justamente possibilitado pela fratura que a experiência da alteridade/diferença criaria no eu mesmo.

Diante desse outro que fala em nós, não seria nosso eu mesmo também a sua alteridade? Nesse sentido, parece que apenas poderíamos afirmar, como o poeta: "Vivem em nós inúmeros/ [...] Sou somente o lugar/ Onde se sente ou pensa.” (Pessoa, citado por Safra, 2004, p. 67). Essa ideia, além de estar presente na literatura e na psicanálise contemporânea (Safra, 2004), pode ser encontrada também em Freud (1923/2006r):

As experiências do ego parecem, a princípio, estar perdidas para a herança; mas quando se repetem com bastante frequiência e com intensidade suficiente em muitos indivíduos, em gerações sucessivas, transformam-se, por assim dizer, em experiências do id, cujas impressões são preservadas por herança. Dessa maneira, no id, que é capaz de ser herdado, acham-se abrigados resíduos das existências de incontáveis egos; e quando o ego forma seu superego a partir do id, pode talvez estar apenas revivendo formas de antigos egos e ressuscitando-as. (p. 41).

Nessa passagem, além da histórica discussão com C. G. Jung, Freud (1923/2006r) remete-nos a uma ampliação da noção de alteridade, por meio da sua famosa segunda tópica. Os lugares ou regiões do psiquismo seriam, assim, abrigos de resíduos de diferenças dos antepassados, que existem em nós por sermos nós mesmos. Ressuscitar as formas dos antigos egos seria possibilitar a emergência em nós mesmos daquilo que há de outro em nós.

A importância da alteridade/diferença nunca foi posta em dúvida também por Winnicott. Em Consultas terapêuticas em psiquiatria infantil, Winnicott (1971/1984) 
comenta que diversas crianças que vinham se consultar com ele narravam, na primeira consulta, que haviam sonhado com ele na noite anterior, sem que o conhecessem. Essa observação fê-lo considerar que elas, antes mesmo de irem à sessão, ansiavam por alguém que pudesse acabar com certo estancamento de suas possibilidades de ser; continuavam tendo esperança de que haveria um outro com quem se poderia novamente ansiar certa continuidade do sentimento de ser. A possibilidade desse encontro retomaria a esperança do anseio por ser aquilo que se pressentia ser.

Esse outro, essa diferença, seria marcadamente uma irrupção de uma ruptura naquela ordem da realidade que fora estabelecida precariamente, impossibilitadora do desenvolvimento porque não poderia tolerar o novo. A alteridade poderia, assim, recolocar em trânsito a experiência de abertura da criança consigo mesma, como a emergência daquilo que demanda ser no acontecimento presente da vida mental. O outro pelo qual se ansiava seria essa “outrossidade" de si mesmo. Desse modo, aberta aos acontecimentos transitórios da experiência emocional, a criança poderia recuperar o sentimento de ser (estar) viva. O outro, um novo anfitrião, é aquele que recebe e põe em devir; faz isso porque é o pressentimento das possibilidades futuras da própria criança, que são aceitas como a alteridade que destrói a imanência da repetição que faz adoecer.

\subsection{As Preconcepções e a Tolerância à Frustração}

Embora o anseio e a alteridade possam ser descritos como modos de aparecimento do Real, eles podem ser caracterizados como desencadeantes de direções muitas vezes opostas. O anseio é uma tendência por tentar criar realizações que não frustrem, ou seja, quando se anseia, procura-se encontrar na realidade aquilo que poderá satisfazer o anseio; quando isso ocorre, há um sentimento de que aquela necessidade foi provisoriamente alcançada. Embora a necessidade 
como tal não possa ser jamais, de fato, alcançada e resolvida, e sua tendência seja infinita, mesmo com a satisfação do anseio desencadeado pela necessidade, há momentaneamente uma realização que se expressa no sentimento de se ter pai e mãe, uma pátria ou terra, de não se estar só ou de possuir algo.

O anseio também pode ser descrito, tal como fez Bion (1962/1994c), em Uma teoria sobre o pensar, como uma preconcepção que busca uma realização para se formar como conceito. Para o autor, as preconcepções, inatas, procuram sua realização e, quando isso ocorre, o que se forma é o conceito a partir do qual a preconcepção se baseava. Neste trabalho, com esse ponto de vista, parece-nos que as preconcepções são origens de nosso movimento por pessoas, coisas, paternidade e terra. Elas são vazias, negativas, ou seja, são basicamente solidão originária, nada, orfandade e desterro, negatividades puras e jamais entificáveis, por isso inexistentes, conforme já discutimos anteriormente.

Nesse esquema proposto por Bion (1962/1994c), podemos nos deparar com algumas questões que nos parecem muito importantes. O autor afirma, por exemplo, que caso uma preconcepção que busque uma realização não se realize, forma-se um hiato entre ela e o mundo, o qual é o espaço mental vazio, de frustração, que passa a ocupar a mente da pessoa. Diante disso, duas são as possibilidades: tolerar ou não tolerar esse estado. Quando não se tolera esse estado, a frustração tende a ser sentida como uma presença má dentro da pessoa, que tende a ser projetada para fora. Já com a tolerância da frustração, o anseio pela realização é postergado, tal como Freud (1911/2006s) afirmou em Formulações sobre os dois princípios do funcionamento mental. Nessa capacidade de tolerar o anseio não realizado, há também a possibilidade de surgirem os pensamentos que podem ser pensados, ou seja, pensamentos que aparecem como uma tendência a modificar o ambiente, para que se possam realizar as mesmas preconcepções, os mesmos anseios. 
Restringirei o termo 'pensamento' à união de uma pré-concepção com uma frustração. O modelo que proponho é o de um bebê cuja expectativa de um seio se una a uma 'realização' de um nãoseio disponível para satisfação. Essa união é vivida como um não-seio, ou seio ausente dentro dele. O passo seguinte depende da capacidade de o bebê tolerar frustração [...]. Se a capacidade de tolerar frustração for suficiente, o não-seio se transforma num pensamento, e desenvolve-se um aparelho para pensá-lo. (Bion, 1962/1994c, p. 129).

Desse modo, Bion (1962/1994c) elabora a ideia de que a capacidade de pensar está intimamente ligada à capacidade de tolerar a frustração que decorre da não realização de nossas preconcepções. Seguimos essa ideia dizendo que o anseio procura, dessa forma, criar uma realidade a partir daquilo que foi, de antemão, pressentido como ausência, não propriamente como um estado positivo, mas negativo. $\mathrm{O}$ anseio parece iniciar a partir de uma preconcepção, que é necessária, em certa medida, para o psiquismo. Essa preconcepção quer se realizar e aparece como um anseio sem fim, por meio do pressentimento da ausência, do negativo da preconcepção. Em seguida, haverá a realização dessa preconcepção, que é também a formação de um conceito; por exemplo, a experiência de se ter um pai, ou seja, de ser um filho. O anseio, que parte do pressentimento do negativo, vai em direção à realização e formação de um mundo a partir de uma oposição ao pressentimento do Real negativo. Nesse sentido, é também uma abertura do homem para que a preconcepção seja saturada, preenchida.

A alteridade/diferença deve ser compreendida de forma oposta, uma vez que é o modo de aparecimento do Real nos elementos que estavam saturados, na realidade compartilhada do mundo; ela "retira" das coisas justamente seu elemento conhecido, compartilhado, "comum". No sentimento de paternidade, pode sobrevir, assim, o pressentimento de que ainda se é, inevitavelmente, órfão ou de que, mesmo junto das pessoas queridas e amadas, se é, essencialmente, só. Nesse sentido, o pressentimento da alteridade - ou da heterogeneidade - é a porta de entrada para o Real, que se anuncia por meio da irrupção da diferença, do estranho e do desigual naqueles conceitos firmados a partir da realização das nossas preconcepções. Assim, 
podemos afirmar que, enquanto o anseio busca "pôr" realidade por meio de nossas preconcepções, diante do pressentimento da nossa condição de negatividade, a alteridade/diferença "retira" do mundo os elementos representacionais designados como realidade, naquilo que há de comum, costumeiro, familiar e alienante.

Em ambos os casos, o Real é pressentido; há um pressentimento daquilo que nos falta a ser, daquilo que originalmente não somos, mas que procuramos nos tornar, mas, tal como sabemos, esse tornar-se não é algo que se finaliza. Nosso anseio por tornar-se decorre do pressentimento daquilo que nos falta a ser, diante de nossa ânsia por sermos determinadas condições existenciais positivas: o lado de "dentro" do mundo. Nossa experiência da alteridade/diferença recoloca-nos novamente diante do próprio vir a ser de nós mesmos, diante de nossa falta a ser, do desconhecimento profundo sobre a nossa própria condição e da estranheza de nosso mundo. Assim, sabemos que tanto a alteridade/diferença quanto o anseio guardam um parentesco entre si, uma vez que têm a mesma origem: o Real. 


\section{TURBULÊNCIA NA CLÍNICA}

Neste momento de nosso trabalho, realizaremos uma discussão sobre o Real com a intenção de ampliar nossa possibilidade de relacioná-lo com outras formas de pensar a clínica psicanalítica, em especial, o problema da função alfa e da mudança catastrófica. Nossa intenção, portanto, será ligar ideias ou pensamentos talvez ainda não ligados ou relacionados entre si, de modo a ampliar ou expandir uma discussão sobre o Real que parece nunca se esgotar, ser justamente inesgotável. Assim, nossa intenção pode parecer vã para um pensar que proponha esgotar a fonte de sua interrogação, mas, caso mantivermos clara a nossa visão sobre seu sentido, poderemos nos lembrar daquele famoso verso de Tagore (1913/1950, p. 13), que diz: "Não consigo encontrar o sossego; sou um estrangeiro para o meu próprio coração."

Por meio desse verso, lembrarmo-nos que é desse desassossego que não só poderemos escrever, mas que encontraremos um relativo lugar de encontro com o pensar inacabado, com o pensar que não precisa ser formulado, com a intenção de esgotar uma interrogação que fora feita. Aquilo que desassossega é, parece-nos, o que nos conduz reabastecidos para a nossa própria morada: o "entre" mundos impossíveis. Assim, poderemos nos manter em um caminho do pensamento, aberto pelo próprio pensar, tal como fazemos em nossas análises. Somos, ao que parece, lugar onde pode ocorrer um pensamento que é mais amplo do que nosso eu mesmo e que surge como uma estranha heterogeneidade inominável. Portanto, caso consigamos criar remissões para aquele lugar de onde surgiu o nosso pensar, para que possamos manter nosso pensar como que habitado pela não coisa (no-thing), pensamos que o leitor poderá eventualmente vislumbrar e prosseguir esse caminho com seu próprio caminho.

Nosso propósito, neste momento, será demonstrar, nesse inacabamento do pensar, a dificuldade que encontramos em tolerar a experiência do Real na clínica psicanalítica. O aparecimento do Real de um modo disruptivo e heterogêneo ou por meio de uma possibilidade 
de pensar o inefável, contendo-o em nós como negativo, traz inevitavelmente turbulência, ruptura e insegurança. Como poderemos pensar que isso que nos desaloja pode, no entanto, conduzir-nos para uma verdadeira hospitalidade no mundo transfigurado por sua aparição e por seu desabrigo? Gostaríamos de discutir, neste capítulo, essas questões, formulando que a turbulência ou o caminho da tempestade parece ser o caminho para um reencontro com a experiência emocional transitória e errante, que desabriga para nos abrigar na própria destituição do eu mesmo. Trata-se, assim, de uma tarefa analítica em que estamos nos havendo com rupturas e expansões da apreensão da realidade mental, mas que também nos parece uma tarefa profundamente intrigante: a de manter a continuidade da experiência de ser, diante de determinadas expansões e rupturas, diante da apreensão do negativo de nosso ser. Para tanto, o "entre" mundos parece ser o lugar de consumação dessa experiência, que é o lugar dos acontecimentos da clínica psicanalítica, tal como procuraremos descrever.

\subsection{A Abertura e as Bordas}

Bachelard (1957/1989), em seu livro A poética do espaço, ao discutir sobre o problema da dialética do interior e do exterior, realiza uma importante crítica sobre aquelas metáforas espaciais que pretendem espacializar o pensamento e, assim, esquematizá-lo. Do nosso ponto de vista, tal crítica parece ser a base para que possamos entender a dificuldade de representar aspectos de uma ontologia que, inevitavelmente, é sempre avessa a representações, mesmo a representações geométricas. Ele diz:

O exterior e o interior formam uma dialética de esquartejamento, e a geometria evidente dessa dialética nos cega tão logo a introduzimos em âmbitos metafóricos. Ela tem a nitidez crucial da dialética do $\operatorname{sim}$ e do não, que tudo decide. Fazemos dela, sem percebermos, uma base de imagens que comandam todos os pensamentos do positivo e do negativo. Os lógicos traçam 
círculos que se superpõe ou se excluem, e logo todas as suas regras se tornam claras. (Bachelard, 1957/1989, p. 215).

Essa crítica de Bachelard (1957/1989) não parece apenas ser fundamental, como também nos indica a necessidade de conduzirmos nosso pensar para além de metáforas geométricas que criem absoluta nitidez e que tragam, assim, uma positividade de imagens que pretendem decidir e figurar o ser do homem pelo dentro ou pelo fora, ou por meio de uma geometria implícita que nos afaste de uma reflexão que vá para além da geometrização. Nosso propósito, com essa crítica, ao realizarmos uma tentativa de representação geométrica, é pensar justamente sobre essa falta de nitidez, sobre a "região" possível para o homem, a qual não é nem exatamente interior, nem exatamente exterior, mas uma região fronteiriça, uma borda, um "lugar" de alteridade/diferença. Sabemos, com isso, que essa descrição há de sofrer os riscos justamente disso que nos alertou o autor: o risco de uma geometria da esquematização e do esquartejamento, uma forma de pensar por meio de divisões positivas e negativas que, no entanto, parecem empobrecer o próprio pensamento.

No entanto, como criar um pensamento que vá além do geométrico sem que passemos, de algum modo, por esse geométrico? O próprio Bachelard (1957/1989), nesse seu precioso livro, algumas páginas adiante, diz: “que espiral é o ser do homem!” (p. 217) e, com isso, dá-se conta de que, ao expulsar das intuições o geométrico, ele parece querer retornar imediatamente! Assim, utilizaremos o geométrico com a intenção de podermos passar por ele e, ao deixá-lo posteriormente, poderemos saber que ele não será mais necessário para nos ajudar a situar-nos com preposições que tendem a se tornar esquemáticas e saturadas. Serão andaimes, escoras e alicerces. 


\subsubsection{A Quaternidade Positiva}

Recentemente, chegou às nossas mãos um conto de Nabokov (1996), chamado Terror. ${ }^{36}$ Esse conto trata da perturbadora e angustiante apreensão da estranheza da alteridade/diferença da qual tratamos no capítulo anterior, mas, além disso, servir-nos-á, neste momento, para mostrar o caminho ou a passagem entre o desabrigo da apreensão dessa estranheza e um provisório abrigo naquilo que descreveremos como quaternidade positiva. $\mathrm{O}$ trecho selecionado que gostaríamos de comentar encontra-se a seguir:

Bem, nesse dia terrível em que devastado por uma noite insone pisei no centro de uma cidade incidental, e vi casas, árvores, automóveis, pessoas, minha mente súbito recusou-se a aceitá-las como 'casas', 'árvores', e assim por diante - como alguma coisa vinculada à vida humana de todos os dias. Minha linha de comunicação com o mundo rompeu-se, eu estava sintonizado numa faixa de onda e o mundo na sua própria faixa, e aquele mundo não fazia sentido. Vi a verdadeira essência de tudo. Olhava para as casas e elas tinham perdido seu significado habitual - isto é, tudo o que pensamos ao olhar para uma casa: determinado estilo arquitetônico, o tipo de aposentos que contém, se é feia ou confortável; tudo isso se evaporara, deixando apenas uma casca absurda, da mesma forma que subsiste apenas um som absurdo quando se repete por tempo suficiente a mais comum das palavras sem atentar para seu sentido: casa, caasa, caasaa. O mesmo acontecia com as árvores, com as pessoas. Entendi o horror da face humana. Anatomia, distinções sexuais, a noção de 'pernas', 'braços', 'roupas' - tudo isso foi abolido, pois diante de mim permanecia apenas um mero algo: nem mesmo uma criatura, porque esse é também um conceito humano, mas somente algo que cruzava por mim. Em vão tentei controlar o terror recordando-me como certa vez, em criança, havia erguido os olhos ainda sonolento ao acordar e vira, inclinando-se para mim por sobre a cabeceira da cama, um rosto incompreensível, sem nariz, com um bigode preto de hussardo logo abaixo dos olhos de polvo, os dentes na testa. Sentei-me com um grito e imediatamente o bigode se transformou em sombrancelhas, surgindo, inteiro, o rosto de minha mãe, que eu tinha visto de início sob um ângulo incomum, de cabeça para baixo. (Nabokov, 1996, p. 105-106).

\footnotetext{
${ }^{36}$ Agradeço ao meu amigo João Rodrigo Oliveira e Silva pelos comentários valiosos sobre esse conto, bem como pela apresentação de seu artigo, que sugiro como leitura: Considerações sobre o conto 'O Terror' de Vladimir Nabokov por uma perspectiva heideggeriana (2001), em que trata justamente do estranhamento e da medianidade como formas existenciais do Dasein.
} 
Nesse belo trecho, Nabokov (1996) transmite-nos o profundo terror da estranha face do mundo, da realidade, destituída de sentido habitual, para em seguida mostrar como pode ser devolvida a face familiar após um grito de terror. A beleza desse trecho, entre outros fatores, reside em revelar, de modo lúcido, como o estranhamento da não familiaridade das coisas desapareceu na redescoberta da familiaridade do rosto da mãe. O autor convida-nos, nesse texto, a nos depararmos com a perda daqueles sentidos familiares que "vestem" a existência dos entes. Ele nos indica, nesse profundo estranhamento, o aparecimento de algo que é somente a crueza do ente destituído de alteridade; algo que é, como veremos, destituído de diferença ontológica.

A realidade estranha, tal como estamos apresentando neste trabalho, é aquela que sofre o acontecimento da irrupção do Real e que se revela inabitável. A face da mãe, desse modo, é expressão daquela quaternidade positiva que nos lança de volta às coisas, para o abrigo na familiaridade daqueles anseios que puderam ser realizados. A familiaridade! Como poderemos tratar dessa ideia de forma a indicar que ela poderá ser um modo de esquecermos nossa condição mais originária, se não nos lembrarmos antes daquela passagem de Levinas $(1980 / 1988)$, que tanto a exalta?

\begin{abstract}
A familiaridade do mundo não resulta apenas de hábitos ganhos neste mundo, que lhe retiram as suas rugosidades e que medem a adaptação do ser vivo a um mundo de que frui e do qual se alimenta. A familiaridade e a intimidade produzem-se como uma doçura que se espalha sobre a face das coisas. Não somente uma conformidade da natureza com as necessidades do ser separado que de chofre dela frui e se constitui como separado - ou seja, como eu - nessa fruição; mas doçura proveniente de uma amizade em relação a este eu. (Levinas, 1980/1988, p. 138).
\end{abstract}

Essa passagem endereça-nos para a doçura da familiaridade e como pode ser ela a possibilidade para o encontro com certo estado amistoso presente nas coisas do mundo. Sem essa familiaridade, nós poderíamos estar amigados conosco mesmos, com nosso eu mesmo, que 
é aquela identidade para a qual retornamos, diante da mesmidade do mundo, quando encontramos justamente a face do heterogêneo, do estranho da alteridade/diferença? Habermas (1998), ao discutir sobre o pensamento de Bataille, diz-nos: "O reino do heterogêneo não se abre senão naqueles instantes explosivos de pavor e fascínio, quando desmoronam as categorias que garantem ao sujeito o relacionamento familiar consigo mesmo e com o mundo.” (p. 299).

Neste momento, estaremos ocupados em tratar justamente desse retorno às coisas ou do modo como as reencontramos após o assombro do desmoronamento do sentido homogêneo e familiar. Para isso, trataremos da positividade de nossa experiência, ou melhor, procuraremos logo a seguir - formular como esse desmoronamento parece atingir justamente a familiaridade, que se parece com uma quaternidade positiva, que iremos apresentar adiante. A imagem da quaternidade positiva poderá nos servir como uma verdade transitória para que, por meio dela, possamos vislumbrar - enquanto lemos e escrevemos - uma abertura. Nosso propósito, assim, é que ela nos sirva como uma abertura e remissão para a própria dimensão que pesquisamos neste trabalho. O espaço criado pelas suas bordas deve permitir que se torne visível sua própria abertura. A experiência que poderemos ter diz respeito aos fundamentos que dão estrutura àquela "teia de aranha" que designamos como escrita biográfica e palimpséstica de alguém.

No capítulo anterior, detivemo-nos na explicitação da quaternidade negativa do Real e formulamos a ideia de que essa quaternidade é aquele desencadeante negativo do anseio pela positividade, sua contraparte. Agora, procuraremos mostrar que as experiências emocionais, fruto preconcepcional, ocorrem diante do espaço criado pelo conjunto da positividade dessa quaternidade, ou seja, a partir do anseio por "coisas", "paternidade", "terra" e "pessoas", para que seja possível o registro da realidade psíquica palimpséstica. Essa descrição positiva tem a função de examinar o modelo de relação que o homem parece estabelecer com o Real.

Essa quaternidade positiva parece formar os limites do espaço por meio do qual a experiência humana ocorre, pela razão de que o ser humano parece acontecer psiquicamente por 
meio de ver "realizado", a partir de suas preconcepções, certo anseio por coisas, pessoas, paternidade e terra; são, assim, modos de enraizamento ou tessituras sobre o abismo do Real. Diante do anseio desencadeado pela quaternidade negativa do Real, o homem vive sob as bordas ou linhas que compõem os limites de seu espaço. A imagem visual que evocamos anteriormente é um espaço, um quadrado que delimita um horizonte de acontecimentos e não somente uma clareira na qual ocorrem desvelamentos, pois mantém uma relação peculiar com aquilo que é próprio do inconsciente não reprimido, uma vez que o inconsciente, como infinito, mora além das bordas dessa clareira e é a própria experiência da abertura diante da qual pode surgir a alteridade/diferença como uma irrupção estranha nas coisas conhecidas. Entre esse espaço "quadrado" e o inconsciente, apenas é possível uma relação de tensão, que não poderá ser concluída durante a vida.

A experiência humana é definida como aquilo que pertence a essa clareira positiva, embora saibamos se tratar também de parte do próprio infinito inconsciente - Real - que, como tal, pode ser descrito do mesmo modo como foi feito por Matte-Blanco (1975/1998) sobre a natureza do inconsciente não reprimido. Com isso, pensamos que a quaternidade positiva do Real parece ser também uma abertura ao infinito, pelo fato de que parece lhe pertencer como uma possibilidade de realização, atribuindo àquilo que é finito sentimentos e possibilidades infinitas pela ação da alteridade/diferença. Não podemos, por isso, tratar essa quaternidade como um quadrado fechado em si mesmo, tal como uma mônada liebniziana, e também não pretendemos formular uma cartografia ou mapa da interioridade. A possibilidade de pensarmos em linhas dessa clareira, linhas de paternidade, de pessoas, de terra e de coisas, e que todas elas podem formar não apenas um espaço (que necessitaria de apenas três linhas), mas também formar geometricamente profundidade, parece ser apenas uma analogia com o fato de que esse espaço tridimensional é o reduto dos pensamentos conhecidos ou recalcados, daquilo que se 
tornou o campo de nosso cuidado, ou seja, que passou a se tornar parte de um registro palimpséstico, esquecido.

Assim, não podemos nos esquecer de que parece haver, nessa forma de representação por meio de linhas, a tentativa de explicitar a necessidade de delimitar um traçado que indique a necessidade de estabelecer um cuidado, para que aquilo que ainda não nasceu - pensamentos sem um pensador - possa encontrar em determinada "região", em determinado "ambiente", ou seja, na análise, a possibilidade para que ocorra, apareça e seja domesticado e cultivado, num cultivo que faça nossa própria mente florescer, por um acolhimento marcado pela atenção livre flutuante, pela rêverie, para o que deve ser ainda pensado e não foi, mas que reivindica, que apela por esse acolhimento, por um pensar que o pense. Isso está presente tanto no pensamento de Bion (1962/1994c, 1974/1975) quanto no de Heidegger (1954/2006). No prefácio de Ensaios e conferências, Heidegger (1954/2006) diz-nos - mas poderia ter sido escrito também por Bion:

No caso presente, trata-se como previamente de empenhar-se a fim de que, graças a tentativas contínuas, se cultive um espaço de acolhimento para o que, desde sempre, deve ser pensado, mas que ainda não o foi; um espaço em cuja liberdade o ainda não pensado reivindique e requisite um pensamento que o pense. (p. 9).

Não iremos discutir as diferenças e semelhanças entre os dois. Nosso propósito é mostrar que ambos formularam a necessidade de se cultivar, pelo cuidado, um espaço continente para a elaboração de pensamentos que reivindicam nosso pensar. Esse espaço constitui-se por abertura e borda, e se articula como familiaridade e intimidade, mas também como heterogeneidade e alteridade/diferença: o cuidado com um ambiente que permite presenciar, além de sua turbulência, a intimidade; uma doçura que se espalha sobre a face das coisas (Levinas, 1980/1988).

A quaternidade positiva, como espaço de cultivo, é o que torna possível cultivar o acontecimento do Real, que é, ainda, um cultivo do próprio pensamento, uma transformação do 
inóspito negativo em formas de um pensar. Devemos, ao cuidar desse espaço tridimensional que é composto pelas bordas de nossos anseios mais primordiais, criar caminhos do pensar, cuidando do cultivo do pensamento, pois, por meio desse cultivo, podemos fazer os traçados das tessituras que nos mantêm provisoriamente sustentados no escuro da noite inabitável do Real e simultaneamente capazes de um dizer que seja sempre a mensagem desse próprio abismo incompreensível. Como nos diz Heidegger (citado por Nunes, 1992): “Questionar é elaborar um caminho, construí-lo. O caminho é um caminho do pensamento. Todos os caminhos do pensamento conduzem, de uma maneira mais ou menos perceptível e por passagens inabituais, através da linguagem.” (p. 291).

Poderíamos pensar nesse campo como um campo icônico, ou seja, como uma expressão que pretende criar a remissão de nosso olhar, como uma janela, para o mais além do ente. $\mathrm{O}$ termo ‘ícone’ foi utilizado também em Grotstein (2010) como forma de designação de “O”; diz o autor tratar-se, assim, de "O", de um sinal icônico abstrato, um sinal insaturado para representar a "coisa em si”. Consideramos, no entanto, que o ícone parece ser não apenas um sinal abstrato, mas qualquer objeto fenomênico, seja ele artístico, científico ou religioso, que revele, em si, insaturação e, desse modo, mantenha-se como janela para além de si mesmo, como uma remissão para o além do ente. Sabemos, com isso, que é preciso que consideremos o ícone não apenas um sinal próprio do objeto, mas uma possibilidade de que determinado objeto seja transfigurado e assuma sua face de ícone. Essa transfiguração parece ser, assim, uma transformação em "O" ou um exercício do pensar que mantenha " $O$ " em nosso campo de experiências ônticas, não como um puro transcendente afastado e desvinculado da experiência.

Esse espaço formado pelas linhas 'coisas', 'pessoas', 'terra' e 'paternidade' forma um quadrado ou uma pirâmide triangular, que tende a ser apreendido como um espaço fechado. Se ele fosse assim, não haveria como designá-lo como uma abertura ao Real. Enquanto o psiquismo humano orienta-se segundo um modo de dar bordas àquilo que foi precocemente 
apreendido como ausência de bordas, o próprio inconsciente humano parece ser aquilo que fura e irrompe nas bordas para a apreensão daquilo que transcende a quaternidade positiva do homem. Terra, coisas, paternidade e pessoas são linhas que formam o espaço de dentro, aquele campo onde as experiências humanas ocorrem, pelo homem procurar, num anseio sem fim, cada um desses "objetos" como seu anseio jamais realizado. No entanto, embora formem o espaço icônico de dentro, permanecem do lado de fora do espaço e são escritas como nomes de "fora", por serem participantes de um anseio irrealizável em sua totalidade, de cada um desses aspectos. Poderíamos dizer, assim, que jamais realizamos inteiramente nosso anseio por paternidade e que jamais realizaremos nosso anseio por um lugar, por uma terra, bem como nosso anseio por coisas ou por pessoas; são anseios que nos orientam como modos de enraizamento e tessitura diante do abismo do Real.

Ao ler cada um dos nomes dessas linhas, portanto, poderíamos nos lembrar imediatamente de sua contraparte negativa. Parece que somente assim deixaremos que o seu paradoxo mantenha-nos insaturados, para sermos convocados para um reencontro novo com cada uma dessas linhas. Em "paternidade", com essa sugestão, poderemos ler simultaneamente “orfandade" e, em "terra", "desterro"; em "coisas", leremos "nada" e, em "pessoas", "solidão". O acontecimento do eu mesmo dá-se no instante em que, pressentindo a ausência, procura-se opor-se naquele lugar, feito clareira, em que se pode obter uma razoável confiança, esperança e fé na positividade da própria experiência (Safra, 2010), embora o temor mantenha certo pressentimento da angústia, como aquela pura abertura à visitação perturbadora do Real.

A forma pela qual o acontecer humano ocorre nessa clareira, aberta pela necessidade humana, é palimpséstica, ou seja, por meio de sucessivas inscrições biográficas, que podem ou não ter relação com as demais. Essas inscrições paradoxais, que são camadas de inscrições, têm a mesma estrutura de uma cebola com suas camadas, sem núcleo, sem um fundamento, sendo apenas a sobreposição de sucessivas camadas de inscrições da vida de alguém. 
Vale lembrar que Bion (1960/2000b), em Técnica Analítica, presente em Cogitações, descreve-nos o palimpsesto como representando camadas de conduta de comportamento de um paciente, ou seja, nesse trabalho, ele nos fornece uma descrição do comportamento humano compreendido não sob a perspectiva de um fundamento recalcado inconsciente que o originou, mas segundo diversos pontos de vista. Determinado comportamento pode ser compreendido como um palimpsesto e, nele, serem detectadas camadas de "escritos" - camadas de condutas. Assim, todo conhecimento de determinado comportamento será um conhecimento que se baseará em uma visão monocular, quando proporcionar uma visão sobre a realidade de uma camada de conduta. As camadas, cada uma delas, podem ser interpretadas como realidade psíquica; caso as compreendamos assim, elas serão as expressões de determinado conteúdo emocional. No entanto, vista em seu conjunto, a realidade psíquica não é somente determinado conteúdo e não é também outro conteúdo, mas o conjunto "palimpséstico".

\subsubsection{O Eu Mesmo como Estrutura Mítica}

Estamos, desse modo, procurando pensar sobre as bordas possibilitadoras do acontecer das experiências emocionais relacionadas com o Real. Logo, deteremo-nos em explicitar que essas bordas têm, também, uma estrutura preconcepcional, a qual, de modo geral, tem a função não apenas de ansiar por sua saturação, mas de ser articulada entre outras estruturas para servir como um modelo de pensar, que tem sua expressão maior no mito, na narrativa e na associação livre.

Alguns mitos podem ser modos de pensar pensamentos impensados, que organizam experiências emocionais com o propósito de orientar o psiquismo humano para uma abertura ao infinito desconhecido. Assim, determinados mitos parecem poder organizar a experiência emocional e manter, ainda assim, uma abertura para que novos pensamentos possam nascer 
dessa mesma estrutura de pensar, desse mesmo mito. Temos, como exemplo disso, o próprio mito de Édipo. Ele, como outros, tem a função de ser reconciliador com o inefável da experiência emocional para a qual aponta e, assim, ser sempre um modelo a partir do qual há algo mais que pode nascer e por meio dele se desenvolver. São modelos de reconciliação com aquilo que nos supera, por poderem se manter em estado de abertura quando - e simultaneamente - fecham e dão bordas para a experiência humana, ou seja, saturam-se de dados sensoriais ou de compreensão.

Bion (1967/1994d), em seus comentários sobre seu livro Secound thoughts, relata-nos, especialmente em certa passagem, algo que pode parecer um tanto quanto surpreendente do ponto de vista dessa reconciliação com o inefável. Nessa passagem, ele está fazendo alguns comentários sobre seu artigo Notas sobre a teoria da esquizofrenia (Bion, 1953/1994g) escrito cerca de quatorze anos antes -, em especial, sobre a parte 39, que falam sobre um momento da análise de um paciente em que há intensa dificuldade por parte deste de experimentar determinados tipos de emoções, as quais tenderiam a desintegrar aspectos do seu ego em pequenas partes e destruiriam a sua capacidade de pensar. Bion (1967/1994d), então, diz-nos:

As experiências delineadas no passo 39 indicam o grau em que a memória e o desejo obstruem a relação do paciente com um seio ou pênis ausentes, num dado nível mental ou determinada época da vida em que tal objeto seria importante a ponto de evocar sentimentos análogos àquilo que, num adulto, seria temor religioso; o que pode ser representado através do termo 'desejo'. Tomando a evidência em seu outro aspecto - ou seja, no 'sentido' memória - o grande mérito da mesma seria a revelação do grau em que o relacionamento do paciente com Deus foi perturbado por modelos (ou elementos da categoria $\mathrm{C}$ ) sensorialmente desejados, os quais impediram uma experiência inefável em virtude do caráter concreto, e da inadequação, portanto, deles, para representar a realização. Em termos religiosos, essa experiência pareceria ser representada por afirmações de que a humanidade ou o indivíduo se deixaram iludir por imagens entalhadas, ídolos, estatuária religiosa, ou, em psicanálise, pelo analista idealizado. [...] O psicanalista aceita a realidade da reverência e assombro, a possibilidade de haver um distúrbio no indivíduo, que 
torne impossível a reconciliação com a realidade última. $\mathrm{O}$ postulado central é de que a reconciliação com a realidade última - ou $\mathrm{O}$, como a denominei para evitar envolvimento com uma associação vigente - é fundamental para um crescimento psíquico harmônico. [...] Em suma, o indivíduo tem, e mantém, o que as pessoas religiosas chamam de crença em Deus, não importa o quanto a negue ou pretenda ele ter-se emancipado. A relação final é permanente, embora sua formulação esteja sujeita a constante reformulação. Deixar de reconhecer esse vértice torna impossível ter-se uma perspectiva equilibrada do indivíduo ou do grupo, e constitui a base da suposição de que existe uma 'reação terapêutica negativa'. (p. 164-165).

Trata-se de uma passagem intrigante, que nos remete a ideias nítidas sobre a função da psicanálise. Gostaríamos de destacar algumas de suas partes; torna-se claro, por exemplo, o valor da experiência de reconciliação com o Real. A reconciliação com a realidade última - ou divindade, tal como Bion nomeia-a em alguns de seus livros, como, por exemplo, em Transformações (1965/2004a) - parece ser o próprio propósito da atividade clínica. Essa reconciliação pressupõe, assim, que a psicanálise surge como uma atividade posterior a uma ruptura da conciliação. Bion (1965/2004a) parece formular, implicitamente, uma ideia de que teria ocorrido, em algum momento, um distúrbio caracterizado pelo rompimento com essa realidade, essa "divindade”, e a impossibilidade de reconciliação seria a expressão da gravidade desse distúrbio.

Essa reconciliação é fundamental para o desenvolvimento, pois significa reconciliar-se com a possibilidade de ser aquilo que se é, muito embora "ser", nesse caso, não possa ser confundido precipitadamente com algum predicado ou forma de entificação. Encarnar-se de sua própria realidade - parece ser esse o propósito dessa descrição - significa reconciliar-se consigo próprio, não com aquilo que é uma ilusão de si mesmo, tais como idealizações sobre a própria personalidade ou sobre a personalidade do analista, mas com a realidade da reverência e do assombro do próprio inefável. Reverenciar a realidade última, ou seja, honrá-la e respeitá-la, 
conduz aquele que está em comunhão, ou está uno com (At-on-ment $\left.{ }^{37}\right)$, a acatar aquilo que clama por ser e, assim, deixar ser o que é disruptivo e assombroso. A realidade da reverência e do assombro é a expressão da realidade surpreendente, aquela expressão do "terror" - como nos descreve Nabokov (1996) - da alteridade/diferença, com a qual se pode eventualmente amigar quando a negatividade e instabilidade do Real transformem-se em formas ou em pensamentos ainda não pensados na atividade analítica.

Bion (1962/1994c) formulou com originalidade a ideia da existência de "pensamentos sem um pensador"; esses pensamentos - os "não nascidos" - buscariam um pensador capaz de pensá-los. Esse postulado, desenvolvido em seu trabalho Uma teoria sobre o pensar, formula que o pensar passa a existir para dar conta dos pensamentos e, nesse sentido, difere de qualquer teoria que indique que o pensamento é produto do pensar. Além disso, com essa formulação, o autor inverte a lógica da "relação" com as ideias, formulando que esses pensamentos - ou "a divindade" - precisariam consentir serem encarnados na pessoa do analisando e não que o analisando consinta tornar-se esses pensamentos. Temos, portanto, dois pontos de vista que podem se mostrar aparentemente antagônicos: o primeiro trata a psicanálise como uma atividade cujo propósito seria possibilitar a reconciliação com o inefável da experiência emocional, ou com a sua "divindade"; e o segundo, como estamos apresentando neste momento, trata do consentimento da "divindade" para encarnar-se na pessoa do analisando.

A primeira formulação poderia assemelhar-se a uma atividade determinada pelo querer do analisando, no sentido de promover, por meio de si mesmo, essa reconciliação. Já o segundo ponto de vista observa justamente que a "direção" da análise é possibilitar que ocorra esse acontecimento, denominado por Bion (1962/1994c) de "encarnação", que não pode ser promovido por ninguém. Pensamos, portanto, que a reconciliação, tal como o autor sugere,

\footnotetext{
${ }^{37}$ Essa palavra indica, segundo nossa compreensão, um estado de unicidade que a palavra 'comunhão' apenas nos sugere, pois fica sem expressar a radicalidade dessa experiência; por isso, a tradução de at-on-ment como "estar uno com" parece-nos mais fiel ao sentido original, tal como nos mostra Sandler em sua tradução para o português do livro Transformações (Bion, 1965/2004a). No entanto, como o seu emprego no português pode tornar o sentido das frases mais difícil, preferimos utilizar, por vezes, a palavra 'comunhão'.
} 
apenas poderá ocorrer quando o próprio inefável puder ser "tornado" aquilo que deve se tornar. Ambos os pontos de vista não nos parecem discordantes, pois tanto o primeiro quanto o segundo tratam da importância de considerar o trabalho analítico um cultivo da abertura que possibilita o acontecimento da visitação do Real no analisando, ocorrendo, assim, essa reconciliação.

Grotstein (2010), discutindo sobre essas questões, faz algumas afirmações que nos esclarecem significativamente o problema de que tratamos:

Em resumo, Bion está sugerindo que o inconsciente e os órgãos sensoriais sentem-se incompletos e necessitam de um continente transformador para mediá-los. Ele também sugere que o inconsciente, na teoria psicanalítica, e 'Deus', no dogma religioso, buscam uma mente ou alma para realizá-los - ou seja, pra completá-los. Colocado de outra forma, Deus necessita do homem para encarná-lo, o que é mais evidente no catolicismo, mas também no Judaísmo e no Islã. Colocado ainda de outra forma, pensamentos primitivos são como os não nascidos de Wordsworth, buscando atribuições terrenas. (p. 83).

O autor, influenciado pela tradição kantiana de Bion, indica que um pensamento não pensado é aquela preconcepção inerente e inata combinada com dados sensoriais de significado emocional. Os númenos ou coisas em si são "convocados" - a partir da experiência do sujeito a dar uma formatação psíquica diante da possibilidade de que o sujeito seja inundado por uma infinidade de elementos sensoriais impactantes e disruptivos. Desse modo, ele afirma que a encarnação da divindade é simultaneamente a possibilidade de pensá-la como participante de certa formatação ou organização e, por isso mesmo, transformada naquilo que somos por meio daquilo que éramos preconcepcionalmente.

Meltzer (1998), discutindo o papel do mito no emprego dos pensamentos, dir-nos-á que Bion formulou a hipótese de que a espécie humana desdobrou certas tendências em preconcepções que, embora sejam essencialmente particulares, podem encontrar certas aproximações no grupo. Ele cita o mito de Édipo, o da Árvore do Conhecimento do Bem e do 
Mal e o da Torre de Babel como exemplos de mitos cuja origem repousa em preconcepções que, combinadas com os sentidos e as paixões, organizariam certo modo de o pensamento acontecer na mente humana. Isso quer dizer que essas preconcepções serviriam como "modelos" por meio dos quais o pensamento ocorreria na mente individual, muito embora possa ser feita também uma aproximação em relação à sua ocorrência no grupo humano. Pensamos, portanto, que o mito é uma forma de organização do pensamento que, simultaneamente, oferece bordas capazes de limitar e prescrever uma dimensão e também de manter-se como um "nascedouro" de pensamentos. Ou seja, o que seriam os mitos senão um modo de revelação do próprio pensamento? Isso equivale dizer que o próprio Real, de certo modo, parece poder se encarnar naquelas formas que já estariam previamente possibilitadas por ele mesmo. Bion (1965/2004a) compreendeu isso como expressão do aparecimento de "O" (do Real) segundo formas preconcepcionais que, de algum modo, guardam grande parentesco com as formas ideais do platonismo (Figueiredo, Tamburrino \& Ribeiro, 2011).

Hesse (1903/1972), em Peter Camenzind, oferece-nos uma bela imagem desse assunto que estamos tratando: "No princípio era o mito. Assim como o bom Deus, poderoso, em luta por uma expressão, poetizava na alma dos hindus, gregos e germanos, assim continuava ele poetizando, diariamente, na alma de cada criança.” (p. 7). Poetizar na alma de cada criança parece significar que, por meio disso, o "divino" tem sua expressão. Parece, desse modo, precisar do homem, assim como do mito, para aparecer como expressão nos homens. Estamos chamando de mito o meio pelo qual acontece a visitação do Real, que tende a ser organizada por meio de uma quaternidade positiva.

A quaternidade positiva é preconcepcionalmente uma estrutura mítica, forma na qual podem nascer e se desenvolver pensamentos. Por meio dela, o homem descreve seu horizonte de desejo, de sentido e de representação, em que surgem a teia e a tessitura da teia como expressões do eu mesmo, que é a principal manifestação desse mito. A quaternidade positiva, 
assim, é a estrutura mitológica que possibilita e dá as condições para o surgimento do mito do eu mesmo. No entanto, como mito, mantém-se em abertura com a diferença/alteridade, de modo que pode conservar-se como uma preconcepção insaturada, ou seja, ser sempre lugar de acontecimento, de irrupção do Real. Assim, esse mito que descreve as bordas do eu mesmo a partir daquilo que ele necessita para se fazer eи mesmo é, também, constantemente visitado pela irrupção da alteridade/diferença, na eclosão de pensamentos não pensados. O eu mesmo que surge da quaternidade positiva é assombrado pela visitação da alteridade, do Real; nessa visitação, faz o mito expandir-se em direção à própria diluição da mesmidade, quando o eu mesmo passa a ser o lugar de transcendência ${ }^{38}$ e de passagem do Real. O eu mesmo, assim, é uma expressão mítica que se desenvolve por meio da alteridade e se amplia ao ponto de estabelecer até mesmo a unicidade entre toda a multiplicidade no eu mesmo, sentindo-se assim participante, empática e autêntica em cada experiência emocional humana, como se o singular pudesse, de algum modo, expandir-se para uma pluralidade, multiplicidade e universalidade.

Nietzsche (1892/1994a), em A origem da tragédia, após nos trazer uma elucidativa passagem de Schopenhauer, oferece-nos uma indicação dessa ampliação do eu mesmo, nomeada de homem individual, por meio da experiência dionisíaca:

\begin{abstract}
'Como um pescador no seu barco, tranqüilo e pleno de confiança na sua embarcação, no meio de um mar desmesurado que, sem limites e sem obstáculos, levanta e derruba montanhas de ondas cheias de espuma, mugindo e bramindo, o homem individual, no meio de um mundo de dores, permanece sereno e impassível, porque se apóia confiadamente principium individuationis. Sim, poder-se-ia dizer que a confiança inabalável neste princípio, e a serenidade calma de quem nele se compenetra, encontraram em Apolo a expressão mais sublime, e poder-se-ia também reconhecer Apolo a imagem divina e esplêndida do princípio de individuação, cujos gestos e olhares nos falam de toda a sabedoria e de toda a alegria da 'aparência', ao mesmo tempo que nos falam de sua beleza.'
\end{abstract}

Na mesma página descreve-nos Schopenhauer o horror espantoso que se apodera do homem quando, subitamente derrotado pelas formas aparentes dos fenômenos, vê que o princípio da

\footnotetext{
${ }^{38}$ Lembramos que transcendência não significa aquilo que está além da experiência emocional, mas o que revela o além de toda e qualquer proposição ou representação imaginária ou lógica do ente.
} 
causalidade, em qualquer das suas manifestações, tem que admitir uma exceção [...]. Agora graças ao evangelho da harmonia universal, cada qual se sente, ao lado do próximo, não somente reunido, reconciliado, fundido, mas idêntico a si próprio, como se o véu de Maia tivesse sido rasgado, desfeito em farrapos que desaparecem perante o misterioso Uno primordial. Cantando e dançando, manifesta-se o homem como membro de uma comunidade superior: desaprendeu de andar e de falar, mas vai-se preparando para a ascensão. Seus gestos rítmicos revelam uma beatitude de encantamento. Agora já os animais falam, já a terra produz leite e mel, porque a voz do homem adquiriu uma ressonância de ordem sobrenatural. O homem diviniza-se, sente-se deus, e por isso a sua atitude é tão nobre e tão estática como a de deuses que ele viu em sonhos. O homem deixou de ser artista para ser obra de arte. (p. 43-45).

Nietzsche (1892/1994a), nessa encantadora passagem, convida-nos a um mergulho fantástico na expansão e no afrouxamento das bordas daquilo que se mantém como estrutura mítica do eu mesmo e de sua condição de participar do princípio de individuação (ou de identidade) e do princípio de causalidade. Termina com uma frase que nos serve como expressão da própria inversão que procuramos desenvolver neste trabalho: a "divindade" precisa consentir ser encarnada na pessoa do analisando, tornando-o, desse modo, obra de arte. Os ecos desse pensamento nietzscheano fazem-se também ouvir em Bataille (citado por Habermas, 1998), para quem as normas mais antigas da civilização são como diques contra um oceano tempestuoso da natureza, luxuriante e excessivo, que devora as existências individuais para justamente assegurar a plenitude da vida e a sua continuidade.

Além da unidade que rompe a identidade, essa estrutura mítica também pode ser o nascedouro de pensamentos que a afrouxam por dentro. Nesse caso, o eu mesmo, reencontrando a alteridade, encontra na experiência da interioridade também a multiplicidade, uma multiplicidade unida que expressa os rastros da instabilidade da alteridade/diferença, como nesses versos de Pessoa (citado por Safra, 2004), que demonstram como podemos, com a 
indiferença de nosso eu mesmo, que se sente, como uma mosca, o centro voante desse mundo ${ }^{39}$, fazer essa multiplicidade silenciar:

Vivem em nós inúmeros;

Se penso ou sinto, ignoro

Quem é que pensa ou sente,

Sou somente o lugar

Onde se sente ou pensa.

Tenho mais almas que uma.

Há mais eus do que eu mesmo.

Existo todavia

Indiferente a todos

Faço-os calar: eu falo. (p. 67).

Podemos encontrar nesses versos a expressão da multiplicidade no eu mesmo e como, nessa multiplicidade, ele perde significativamente sua característica de mesmidade. Atravessado pela alteridade/diferença, o eu mesmo torna-se afrouxado por dentro e passa a ser o "lugar" de manifestação de outra presença ou de outras presenças dentro de si. Em Freud (1923/2006r), essa ideia está presente na formulação do ego como uma revivência e ressuscitação de formas de antigos egos; em $O$ ego e o id (Freud, 1923/2006r), afirma-nos que no Id achar-se-iam abrigados resíduos da existência de incontáveis egos. Portanto, quando dizemos: "eu falo", como no poema de Pessoa (citado por Safra, 2004), o eu mesmo reafirma-se unitário e todos os “eus" ou a multiplicidade palimpséstica, que pode revelar no seu estranho (Unheimlich) a

\footnotetext{
${ }^{39}$ Nietzsche (1873/1978b), em seu texto Sobre verdade e mentira no sentido extra-moral, oferece-nos a intrigante comparação entre o intelecto humano e uma mosca que sente ser o centro voante do mundo. Diz o filósofo: "Assim poderia alguém ter inventado uma fábula e nem por isso teria ilustrado suficientemente quão lamentável, quão fantasmagórico e fugaz, quão sem finalidade e gratuito fica o intelecto humano dentro da natureza. Houve eternidades em que ele não estava; quando de novo ele tiver passado, nada terá acontecido. Pois não há para aquele intelecto nenhuma missão mais vasta, que conduzisse além da vida humana. Ao contrário, ele é humano, e somente seu possuidor e genitor o toma tão pateticamente, como se os gonzos do mundo girassem nele. Mas se pudéssemos entendermos como a mosca, perceberíamos então que também ela bóia no ar com esse páthos e sente em si o centro voante deste mundo." (p. 45). Parece com isso descrever, por meio desse páthos, justamente a experiência do eu mesmo consigo; sua quase impossibilidade de desenredar-se dessa tessitura de ensimesmamento narcísico.
} 
alteridade/diferença, são aparentemente encobertos e silenciados. Com isso, tornamo-nos sem os vestígios dos sons que surgem de nossos registros, desse espiral palimpséstico esburacado. A manifestação de outras presenças em si é uma possibilidade conciliar, ou seja, Sobornyi. Safra (2004) esclarece-nos essa questão explicando-nos essa palavra:

A consciência humana é Sobornyi, ou seja, conciliar. Toda ação humana é uma ação de nós, a partir do gesto originário que inaugurou o sentido de si e a presença do Outro. Dizer que a consciência humana é Sobornyi é afirmar que ela é uma experiência conciliar, ou seja, tudo o que uma pessoa faz, tudo o que pensa, tudo o que é, não está referido somente ao indivíduo, mas a todas as pessoas que a constituíram. A fala de um é texto de muitos. (p. 68).

Nossa fala, que não cala o outro, parece assim a manifestação desses registros palimpsésticos embebidos de alteridade/diferença e, como veremos, podem ser tanto a dissimulação que nos retira do acontecimento do Real quanto a forma de abrigar e dar contornos enigmáticos para essa "pura" e radical alteridade.

\subsubsection{Não Mesmo, Alteridade e Trauma}

Quando o Real mostra-se de "fora", como a perda das bordas e dos limites do eu mesmo, ou quando se mostra de "dentro", como a ampliação da experiência do eu mesmo para uma experiência da alteridade como multiplicidade em si, há uma realização do pensamento ou do Real que afrouxa justamente as bordas do mito ou de sua própria estrutura preconcepcional. Nesse sentido, podemos nos antecipar e dizer que o Real sempre supera ou excede a si mesmo.

Esse afrouxamento das bordas significa que a estrutura preconcepcional parece ser esticada ou laceada até tornar-se profundamente instável, às vezes imprópria para a continuidade da experiência emocional e para o pensar. A visitação do Real, desse modo, tem a função não apenas de lacear a estrutura mitológica do eu mesmo, como também de fazer com 
que o eu mesmo torne-se realizado pela alteridade, justamente naquelas qualidades que são compreendidas inicialmente como ausência de qualidades: o desterro, a orfandade, a solidão e o nada. Nesses casos, podemos dizer, com o propósito de nos tornarmos mais claros, que o eu mesmo torna-se um não mesmo. Esse eu mesmo esgarçado, laceado pela irrupção da visitação do Real, que procura por meio do mito estar presente no psiquismo, acaba por colocar em questão o sentimento de mesmidade do mundo e destitui, pela irrupção de sua negatividade, nossa experiência de familiaridade com o mundo, a qual, como o familiar rosto da mãe de Nabokov (1996), pode ser o desencontro com a instabilidade da surpresa incessante do não mesmo ou conservar a pujança do mistério da alteridade, como uma doçura que se presencia mesmo na multiplicidade e na diferença do mundo e que, por vezes, encontra-se na face ausente do analista, ou seja, uma doçura familiar que se amplia para o estranho, o desigual, o absurdo e o instável da experiência emocional. O familiar, assim, é o estranho-familiar (Das Unheimlich).

Podemos, no não mesmo, tornar-nos a realização da renúncia de um saber, de uma pessoalidade e da familiaridade com as coisas. No entanto, esse aparente empobrecimento do eu mesmo parece nos reconciliar com os acontecimentos da clínica psicanalítica, restituindo a resplandecência, a multiplicidade e o sentimento de verdade da experiência emocional. Estar sem memória e sem desejo (Bion, 1967/2000a), as célebres recomendações bionianas, parece ser cultivar essa mesma renúncia para que, desse modo, possa surgir aquela experiência que indica o curso de uma verdade que não se contém ainda em certo mito, em certa estrutura ou modelo de pensar. Não poderíamos pensar, portanto, que a tarefa da psicanálise não é a de, cultivando e cuidando de nossa abertura ao Real, possibilitar-nos amadurecer o estado de renúncia, para que o Real possa nos visitar segundo seu próprio acontecimento, laceando, assim, as estruturas do nosso mito pessoal? Isso não seria, além de expansão, também ruptura?

Nesse sentido, tanto a materialidade quanto o rosto da mãe podem ser expressões da presença da visitação. As coisas, a terra, as pessoas e a paternidade tornam-se expressões do 
Real por poderem manifestar a irrupção da alteridade no familiar; nesse momento, parecemos estar em um “entre mundos”. Quando há, na quaternidade positiva, a surpresa da manifestação dessa alteridade, torna-se possível a expressão poética do seu mistério - do velado. No trecho de Nabokov (1996) com o qual iniciamos este capítulo, ele escreve a sua recordação de como pôde controlar o seu terror com a lembrança da recuperação da familiaridade do rosto de sua mãe. Nessa lembrança, ele retorna à familiaridade das coisas, mas a uma familiaridade que é apenas uma mudança de perspectiva. Assim, indica-nos que a não familiaridade ou o não mesmo pode reaparecer facilmente, em uma mudança de ângulo, com uma sintonia em uma "faixa de onda" na qual as coisas, as pessoas, essa terra e até sua mãe desfar-se-iam num absoluto estranhamento. Esse estranhamento, descrito como sendo quase insuportável, coloca o narrador na mais profunda instabilidade. Assim, parece que somente quando pode retornar a alguns aspectos de seu mito pessoal (eu mesmo) é que pode, simultaneamente, manter-se disponível para o acontecimento da alteridade/diferença como expressão poética do eu mesmo. Desse modo, tornam-se possíveis o próprio conto, a palavra que é guardiã da beleza do estranhamento com a alteridade/diferença e uma doçura do familiar que se amplia para conter a potência disruptiva da mobilidade frenética da alteridade/diferença.

Parece-nos que a abertura ao Real pode ser cultivada como um trabalho de amadurecimento do psiquismo, mas, diante do aparecimento do estranhamento da alteridade, na visitação do Real, há simultaneamente uma tendência de diluição do eu mesmo e, com isso, a origem de um estado de profunda perturbação. O retorno à quaternidade positiva pode ser tanto um modo de ocultar e de esquecer essa visitação quanto ser aquele movimento que permite manter certa estabilidade familiar embebida dessa visitação. A descrição poética desse acontecimento perturbador é, muito frequentemente, sua decorrência quase espontânea, como palavras que surgem do seu silêncio, do negativo da experiência; instáveis e incertas, aparecem na clínica como o estranhamento por coisas usualmente comuns e cotidianas. A expressão 
poética, assim, guarda a marca viva dessa quaternidade positiva atravessada, visitada e embebida pelo Real. No dizer das coisas, terra, pessoas e paternidade, há o respeito pela presença inalcançável daquilo que é o pressentimento do que está para além do que foi dito.

O esquecimento do Real, contrariamente, aparece como aquela tessitura do mesmo que procura incessantemente manter as bordas como limites demarcados, quando justamente se experimentou o Real como um atravessamento traumático dessa borda, do irrepresentável, produtor de agonias impensáveis. Nesse sentido, na clínica psicanalítica, podemos dizer que a repetição e o sintoma relacionam-se com o esquecimento do Real quando pretendem fazer do não mesmo mesmidade. Essa mesmidade procura, simultaneamente, dar sentido para a visitação traumática e proteger as bordas, tornando-as menos permeáveis. Winnicott (1990), em $A$ natureza humana, descreve essa mesma situação do ponto de vista da intrusão prematura do ambiente. Ele nos diz:

Num caso menos feliz, o padrão de relacionamento se baseia no movimento do ambiente [...]. Isto merece o título de intrusão (impingement). O indivíduo reage à intrusão que é imprevisível, por não ter relação alguma com o processo vital do próprio indivíduo. Isto, quando repetido, também se transforma num padrão de relacionamento, com um resultado bem diferente. Enquanto no primeiro o acúmulo de experiências parece fazer parte da vida, e ser portanto real, no segundo a reação à intrusão subtrai algo da sensação de um viver verdadeiro, que é recuperada apenas através de um retorno ao isolamento, na quietude. (Winnicott, 1990, p. 149).

Essa passagem de Winnicott (1990), fundamental para a compreensão do sentir-se real no mundo, também fala sobre as bordas e a apreensão do aparecimento, no interior do indivíduo, proveniente de outro lugar, de uma força estranha e invasiva. A reação que se segue à intrusão parece querer demonstrar que, na solidão e quietude, torna-se possível recuperar não só o sentimento de que há algo real preservado em si mesmo, que pode continuar sendo como se é, como a própria relação com o mundo e com a diferença. Acaso não poderíamos utilizar esse mesmo pensamento em relação à nossa exposição sobre as bordas da quaternidade positiva e 
sua permeabilidade ao Real? Pensamos que sim. Desse modo, parece-nos que o autor mostrou que o sentimento de ser real e experimentar a continuidade do sentimento de ser eu mesmo deve-se ao fato de poder manter-se em abertura, descobrindo aquilo que se é numa relação de tensão que não é, de modo algum, traumática ou intrusiva.

Mas foi Freud (1920/2006e), em Além do princípio do prazer, que anteriormente descreveu a relação entre o rompimento dessa barreira de contato, que chamamos bordas, e os efeitos desse trauma, inclusive a compulsão à repetição:

Esse pequeno fragmento de substância viva acha-se suspenso no meio de um mundo externo carregado com as mais poderosas energias, e seria morto pela estimulação delas emanadas, se não dispusesse de um escudo protetor contra os estímulos [...]. A proteção contra os estímulos é, para os organismos vivos, uma função quase mais importante do que a recepção deles [...]. Descrevemos como 'traumáticas' quaisquer excitações provindas de fora que sejam suficientemente poderosas para atravessar o escudo protetor [...]. Ele [o trauma] é causado pela falta de qualquer preparação para a angústia, inclusive a falta de hipercatexia dos sistemas que seriam os primeiros a receber o estímulo [...]. Esses sonhos [de angústia] esforçam-se por dominar retrospectivamente o estímulo, desenvolvendo a angústia cuja omissão constituiu a causa da neurose traumática. (p. 36-41).

Nessa passagem, que mistura, como num sonho, vesícula viva, homem e escudos protetores, Freud (1920/2006e) indica-nos que o cuidado com as bordas parece ser fundamental para conservar a saúde e a integridade. O trauma ocorre com uma ruptura inesperada dessa membrana ou borda que reveste o organismo, ou o psiquismo. Do ponto de vista de nosso trabalho, podemos correlacionar esse pensamento com o próprio Real, ou seja, aquilo que fura ou rompe as bordas passaria a ocorrer dentro do psiquismo como energia livre, como uma presença sobre a qual não se pode representar nada e da qual não se criaria um objeto para o anseio. Trata-se, assim, daqueles “insaciáveis, intermináveis anseios”, que Satã, na descrição de Milton (citado por Britton, 2003), pronuncia ao olhar Adão e Eva no Paraíso. O psiquismo, 
portanto, tomado por uma enorme quantidade de "energia livre", tenderia a utilizar sua disposição para "ligar" essa energia, fazendo com que ela pudesse se tornar representada e participante do mundo mental como anseio por terra, coisas, pessoas e pais. Freud (1920/2006e) compreende que a falta de preparação para esse evento, ou a ausência da angústia, teria um papel fundamental na ocorrência do trauma.

O Real, desse ponto de vista, pode surgir como aquilo que rompe com o sentimento de continuidade do ser e que promove aquele trauma decorrente da ameaça que não foi pressentida. O aparecimento da angústia parece ser, desse modo, fundamental. Com essas ideias, estamos agora mais preparados para compreender que aquilo que interrompe o sentimento de continuidade do ser e que também pode apresentar-se como o irrepresentável que invade o psiquismo despreparado é, na verdade, aspectos da visitação da quaternidade negativa do Real. O abalo do trauma ocorre porque, na ausência da angústia, o homem foi visitado inesperadamente por aquilo que o força a lacear sua estrutura mítica, ou melhor, a história, a narrativa do eu mesmo, do "dentro", que já era contada repetidamente e com o mesmo recomeço, com a mesma resposta repetitiva. Desse modo, invadido pela apreensão do nada, da solidão, da ausência de bordas e do infinito, da orfandade e do desterro, o psiquismo torna-se inteiramente concentrado por dominar essa abertura e, com isso, nomear a visitação desse estranho intruso que tende a desmontar aquelas convicções do eu mesmo. O trauma, assim, abala o funcionamento de toda a estrutura palimpséstica e também a possibilidade de manter determinada abertura ao Real.

Tal como nos mostra Nabokov (1996), há nessa situação uma tentativa de restituição da familiaridade diante do assombro da impossibilidade de transformar em um pensar esse não mesmo, que pode, ainda, ser a expressão da transformação do ente em um puro "algo". Figueiredo (1994), sobre esse ponto, diz-nos: 
[...] traumático é o acontecimento que desancora, o que tira o solo de ancoragem em que se assenta a existência. Este solo é o fundo pré-reflexivo em que e de onde se destacam as figuras com que lidamos cotidianamente, com as quais nos sentimos relativamente seguros e nas quais nos apoiamos. Este solo, que é a proveniência não representada das representações possíveis, é algo que não pode sofrer o efeito corrosivo da dúvida. $O$ trauma abre uma crise de confiança que não implica somente em desconfiar desta ou daquela representação, mas de não confiar na fonte ou matriz de todas as representações possíveis, fonte da qual provinha para o indivíduo 'o sentimento de estar seguro de si'. (p. 159).

O trauma, desse modo, é um acontecimento que promove uma reiterada desconfiança, da qual não se pode evadir, muito embora essa desconfiança na própria segurança da existência não possa ser resolvida ancorando-a simplesmente em qualquer parte. Antes disso, é necessário que o homem possa, a seu tempo, reconstituir aquele fechamento fundamental, diante do qual a alteridade/diferença esgota-se. Assim, tal como nos mostra Winnicott (1990), será somente na quietude e no retorno ao isolamento que a possibilidade da abertura poderá novamente acontecer.

Aquilo que o trauma promove é, acima de tudo, o esquecimento do Real a posteriori, ou seja, na tentativa de dominar aquilo que foi visitado, há uma tendência do psiquismo de fechar a abertura e manter as suas bordas preparadas para a proteção por eventual nova intrusão. Desse modo, cuida-se para que, no fechamento, no isolamento, possa se reconstituir certa familiaridade em que se pressentem aqueles aspectos habituais de nosso ser eu mesmo. Com isso, o não mesmo é combatido em sua presença e, para tanto, utiliza-se aquilo que se pode: transformações de "O" para elementos de um pensar, como sonhos, pensamentos oníricos, palavras, conceitos etc., além da manutenção de respostas e afirmações duras sobre a realidade, agora formada como conceito, formulada de modo delirante, por não poder mais disponibilizarse para a apreensão de uma nova experiência emocional. Isto, em seu extremo, é a expressão do que impossibilita a inscrição de novos registros palimpsésticos e a tolerância ao centro ausente da experiência emocional. 
Bion (1965/2004a) ressalta que a psicanálise constitui-se de uma série contínua de transformações ou movimentos progressivos efetuados a partir de uma mesma invariante, que é desconhecida. A interpretação efetuada no curso de uma sessão, como vimos, é uma tentativa de atingir essa invariante (a coisa em si). Essa descrição do universo das transformações pode ser também compreendida por meio da teoria da função alfa; Caper (2002) descreve essa teoria dizendo que Bion (1965/2004a) fez com ela uma reelaboração da teoria freudiana da barreira de contato, presente em Projeto para uma psicologia científica (Freud, 1895/2006g). O propósito dessa barreira de contato seria efetuar uma separação entre a consciência e o inconsciente, de modo que se torne possível, com essa separação, um contato entre os dois. A barreira de contato, desse modo, separa dois modos de acontecimento psíquico, mas sua principal característica é a transformação de elementos ainda não pensados ou elementos incapazes de ter quaisquer significados, em formas de um pensar ou em elementos alfa, que podem ser associados uns aos outros e se tornar, portanto, símbolos.

Há, nessa transformação efetuada pela função alfa, um trabalho que pode ser comparado a um trabalho de tradução, mas de uma tradução que criaria aquelas palavras que ainda não tinham sido pronunciadas. Trata-se de uma tradução, pois é a conversão de um elemento beta (incapaz de ter significado por si mesmo ou elemento impensável) em elemento alfa, por meio de uma função alfa que está presente nessa barreira de contato, tal como uma tela alfa. Os elementos alfa, desse modo, seriam pensamentos oníricos, sonhos ou elementos que se tornam disponíveis para o sonhar. Podemos pensar até que ponto essa conversão de elementos beta em elementos alfa não faria com que, nessa transformação, grande parte dos elementos beta acabe se "perdendo" pelo caminho, ou seja, os elementos alfa já seriam transformações que expressariam também as limitações de nosso modo de apreender esses pensamentos sem pensador, os elementos beta. 
Alguns autores (Ferro, 2003; Grotstein, 2010) têm enfatizado a importância de considerar que se trata de um processo de desconstrução de elementos indigestos por elementos que podem se tornar mais adequados para serem absorvidos pelo psiquismo humano. Para o nosso psiquismo, os mitos são especialmente importantes, pois dizem respeito ao modo ficcional com que lidamos comumente com a verdade e com o Real, e, por outro lado, a um modo preconcepcional de organização de dados sensoriais. No entanto, na teoria das transformações, é importante considerar também que a produção de mitos parece ser uma função essencial da função alfa (Bion, 1967/2000a). O mito do eu mesmo coaduna-se a essa compreensão, muito embora, como havíamos visto anteriormente, possa ser compreendido como um aspecto da própria encarnação do Real segundo suas preconcepções. ${ }^{40}$

O Real, tal como nos mostra Figueiredo (1994), demanda tradução, não porque, segundo o autor, exista algo específico a ser traduzido, mas porque se torna necessário, com essa presença indomável sobre o psiquismo, por vezes traumática, dar algum tipo de figurabilidade ao enigma disruptivamente proposto. Podemos pensar, assim, nessa possibilidade de conversão de elementos beta em elementos alfa por meio dessa barreira de contato efetuada por uma tela alfa, de modo a realizar uma tradução; mas será que o Real poderia ser assim traduzido, de modo que ele se torne totalmente apreendido? Essa conversão não seria, assim, uma forma de tentar juntar, aglutinar, ligar e representar elementos que ficam necessariamente sempre insaturados, sempre decantando e "sobrando" para nós? Podemos, de outro modo, pensar na angústia, pois não seria ela justamente aquela experiência que garantiria com que o Real pudesse nos visitar e sua presença não transformada ser a realidade que nos traz o estado descrito por Bion (1967/1994d) como da reverência e do assombro em face de “O”? Não seria a angústia um modo de aparecimento desses elementos beta em sua pura radicalidade, como

\footnotetext{
40 Nesse sentido, podemos observar uma dupla possibilidade de compreensão da origem do mito: ser a representação narrativa de certa atividade da função alfa ou ser a expressão de um modo a partir do qual o próprio pensamento já acontece na mente humana. Pensamos que isso se relaciona com uma dupla influência não inteiramente solucionada no pensamento de Bion (1967/2000) - do qual o nosso trabalho descende: a tradição kantiana e a tradição platônica. Veremos adiante certas decorrências e implicações dessa dupla influência.
} 
visitação do Real que se faz surgir na estranheza da alteridade/diferença do sentido e do ente, mas sem que se torne, desse modo, uma experiência traumática?

\subsubsection{Demandas do Real}

Certamente, esse problema do trauma conduz-nos para uma nova reflexão sobre o tema. Caso consideremos como válida a hipótese de que, por um lado, o psiquismo humano apreende precocemente o Real e esforça-se continuamente para elaborá-lo, distanciando-se dessa apreensão e de certo pressentimento dele, então o papel da ilusão parece ser fundamental na experiência de sentir-se real. Assim, sentir-se real parece ser fundado na possibilidade de estar aberto às experiências para as quais não há um sentido original e poder, desse modo, produzir aquele sentido que estava lá para ser criado, a partir das necessidades fundamentais de terra, pessoas, coisas e paternidade. Nessa realização de um anseio fundamental, há, simultaneamente, um processo de criação de um "objeto" - como "pai" ou "mãe" - que estava pronto para ser criado, um "há" que se torna ainda realizado, criado, existente, tal como nos apontou Levinas (1997). Esse existente, esse objeto tornado existente, é parte tanto do anseio realizado quanto de um mundo de sensorialidade. No entanto, sempre que há a realização de um anseio fundamental, podemos dizer que, de alguma forma, ocorreu um pressentimento da quaternidade negativa.

Como já havíamos pensado, o negativo do Real desencadeia o anseio pela realização dos elementos da quaternidade positiva. Assim, podemos dizer que, por mais que o psiquismo humano procure se distanciar desse pressentimento do Real, por mais que procure se aferrar às coisas que já possui ou tente se manter afastado de um pressentimento da angústia, a mente humana aspira continuamente por saturar a insaturação de um Real que demanda ser. Desse modo, parece que a tentativa de esquecimento persistente do Real pode fazer, inversamente, 
com que a visitação do Real ocorra de modo traumático e inesperado, justamente pela falta de preparação para o Real. Como poderemos cuidar do psiquismo humano para que isso não ocorra? Pensamos que a psicanálise pode se situar entre as atividades humanas cujo propósito é manter o homem disposto a cuidar de sua abertura ao Real e manter-se em reconciliação com aquele desconhecido que clama por realizar-se em nós. Trata-se possivelmente de parte de um mito humano relacionado com a preparação para o contato realizador da "divindade", sob o primado da receptividade silenciosa do "vazio e sem forma", tal como foi expresso por Blake (1984).

No entanto, devemos voltar ao problema da demanda por tradução do Real, tal como nos apontou Figueiredo (1994). Parece-nos que se torna interessante transcrever toda essa passagem, que se encontra em seu trabalho Fala e acontecimento em análise; diz-nos ele:

O Real demanda (o que Laplanche chama de) tradução; no entanto, é esta 'tradução original' que dá ser ao enigma, que o realiza; ou seja, não há já algo a ser traduzido, embora haja uma 'demanda de tradução'. Em vista disso, no lugar de 'tradução' proporei nas últimas lições que se fale em respostas metaforizantes, capazes de dar uma certa e sempre precária figurabilidade ao enigma. (Figueiredo, 1994, p. 157).

Nessa interessante passagem, o autor indica-nos que o Real demanda certa figurabilidade, porque é com ela que ao enigma é dado um ser. Certamente, o autor refere-se à ideia de ser como predicativo, ou seja, como um complemento que atribui atributos inerentes e adequados (Houaiss, 2009), por meio do qual se possa dizer o ser e, nesse sentido, dar uma figuração, mesmo que inevitavelmente precária; isso se deve ao fato de que não há como se pensar em atribuir uma figuração totalizante. Pensamos que essa colocação muito se assemelha àquela de Badiou (2002), quando nos diz: 
Se uma verdade não se diz toda, é que seu todo, todos os seus componentes, não se deixa circunscrever por um traço predicativo único. Não se pode saber uma verdade; não se pode dizer: eis o critério em função do qual reconheço todos os componentes de uma verdade. (p. 66).

Ou seja, uma verdade, expressão limitada e determinada pela castração, indica-nos que se mantém inominável porque dela ainda falta muito a falar e a se tornar. Qualquer figuração, assim, será sempre precária, mas poderá, por outro lado, ser aquela forma poética de falar o Real de modo a que a figuração conserve-se como aquilo que aponta para além de si mesma, em direção ao mistério daquilo que se revelou e para a dimensão daquilo que ainda não se tornou presente, portanto para a dimensão de velamento do Real. Desse modo, aproximamo-nos de um dizer poético que pode ser a base para pensar um momento posterior do trauma, uma vez que o primeiro momento seria marcado por um fechamento das bordas, cuja intenção seria reconstituir aquela experiência de abrigo na repetição de certa familiaridade, restabelecendo a angústia para determinada experiência passada que se mantém presente.

Podemos, agora, afirmar que o Real é fundamentalmente uma demanda, que exige principalmente ser, ser um existente. O Real demanda: $\left(1^{\circ}\right)$ ser não mesmo: tornar-se (o eu mesmo) a marca da alteridade/diferença e, assim, abrir-se como janela para além do ente; $\left(2^{\circ}\right)$ ser renúncia: destituir-se de terra, coisas, pessoas e paternidade; além disso, na renúncia, podemos nos destituir também de memória, desejo e compreensão; $\left(3^{\circ}\right)$ ser expressão fenomênica das preconcepções que o constituem, como uma clareira fundada pela quaternidade positiva: ter objetos, filiação, relacionamentos e uma morada; e $\left(4^{\circ}\right)$ ser aquilo que pressente sua falta a ser e que anseia por mais ser.

Na renúncia, há uma permanência de insaturação, mas, nessa permanência, o que ocorre é justamente a saturação daqueles elementos com os quais somos tornados. Isso equivale dizer, para a clínica psicanalítica, que "[...] em termos de experiência psicanalítica, o psicanalista sabe a respeito do que o paciente diz, faz, e está sendo, mas não alcança o ' $O$ ' de que o paciente é o 
evolver: só pode ser tornado.” (Bion, 1970/1991a, p. 37-38). Nesse "ser tornado", o analista, em renúncia, pode ser aquilo que está ali para ele ser, ou seja, seu existir ocorre de modo a se tornar saturado pelos elementos que são esse comum pertencimento de analista e analisando, muito embora o analisando não deva permanecer, necessariamente, em renúncia.

Ser renúncia significa, em outras palavras, manter-se disposto para que seja retirado aquilo que aparentemente é a fonte de nosso sentimento de mesmidade, para que seja restituído nosso encontro com o mundo na resplandecente abertura da reconciliação do que há de inominável na experiência. Somente desse modo podemos também compreender as palavras de Bion (citado por Sandler, 2005b), que dizem:

Quanto mais suas interpretações possam ser julgadas como demonstrando como seu conhecimento, sua experiência, seu caráter são necessários para formular aquele pensamento daquela maneira que foi formulado, mais razão existirá para supor que a interpretação é psicanaliticamente inútil, ou seja, alheia ao âmbito O. (p. 37).

Assim, podemos entender que o Real, ao retirar, mostrando ser absolutamente desnecessário aquilo que nos parece ser de tanto valor, doa, oferecendo aquilo que somos sem o atravessamento do mesmo. Nessa situação paradoxal, oferece aquilo mesmo que retirou: terra, paternidade, coisas e pessoas, mas sem a permanência desses elementos com aquela significação marcada sob o primado do eu mesmo. Na renúncia, há a possibilidade de que possa ser mantida a abertura que não é traumática, porque se articula uma preparação para essa visitação do Real, a qual é o cuidado progressivo com a própria renúncia e com o ser não mesmo, ou ser o outro (inconsciente) plural, múltiplo. Apenas na reconciliação com o inefável da experiência do mundo é que podemos entender como ela restitui a própria experiência do eu mesmo por meio do não mesmo, agora transformado no próprio inefável transfigurador da experiência e não apenas na palavra tamponada. 
[...] uma revoada de pássaros, uma árvore florida, um bebê carinhoso e fofo, um matagal sacudido pelo vento, uma mulher atraente e bela, uma tempestade de verão, uma noite estrelada e escura, um jardim de bom gosto, a imobilidade de um bosque de pinheirais, uma praia deserta ou, então, um viçoso ramo de planta. Antes de tudo, e um estado interno de sintonia com a vida superabundante que existe na natureza, e este estado decorre de nossa capacidade para experimentar a alegria de viver. Nos momentos de maior aproximação e encontro com a vida, é difícil fazer a distinção entre o interior e o exterior, embora, paradoxalmente, nós nos sintamos mais bem fortalecidos e solidificados em nossa individualidade. (Trinca, 1998, p. 49-50).

Somos paradoxalmente, na visitação do Real, essa indistinção entre a pobreza da renúncia e a riqueza do esplendor da existência. Talvez por isso, e apenas por isso, o trabalho clínico não seja extenuante, na experiência de atendimento contínuo de inúmeras pessoas, e possa sempre nos deixar ser aquilo para o que somos convocados a ser: para a alteridade/diferença de nós mesmos, fazendo com que, de algum modo misterioso, possamos com isso nos tornar mais bem fortalecidos e solidificados em nosso eu mesmo, na experiência de que ela é aquele espaço para onde retornamos, com o terrível e comovente saber de que nele não demoraremos demasiadamente; o Real convocar-nos-á. Trata-se, assim, de compreender que a transferência é uma experiência de mobilidade, na qual podemos aceitar ser aquilo que de algum modo clama por surgir no palco analítico, para que possamos, pela interpretação, colocálo novamente em devir, de modo que assim não se torne alienação e esquecimento do Real.

O que não seria essa renúncia senão a castração e a impossibilidade de o Real ser algo como uma realização totalizante extática? A renúncia, em sua disposição de instabilidade, aceita o Real como alteridade/diferença enquanto permanece disposto para tornar-se o que não se finda e jamais poderá, assim, tamponar a própria abertura, fazendo dela uma fantasiosa verdade totalizante. No Real que demanda ser, fundamentalmente, há uma renúncia efetuada para que um não mesmo possa sempre (re)começar a ser. 


\subsubsection{A Castração e o Outro Quarto}

Britton (2003), quando nos descreve a relação entre o "outro quarto" e a criação do espaço poético, poderia, de outro modo, ainda complementar, mostrar do mesmo modo a relação entre a nossa possibilidade de apreensão do Real e a castração. Embora o autor não ponha em relevo essa questão, parece-nos que ela se encontra subjacente às suas concepções sobre a capacidade humana de relacionar-se com o próprio psiquismo e com o Real. Caso consideremos que o "outro quarto" é, acima de tudo, a expressão, por meio da imagem de um lugar, da pura alteridade/diferença, então ficará mais fácil observarmos essa correlação.

O "outro quarto" é, primeiramente, o que nos convoca para a cena primária, em que, fundamentalmente, institui-se uma relação triádica, na qual há um terceiro - observador - que não participa diretamente de uma relação desconhecida. A observação, portanto, ocorre mais na invisibilidade dessa cena "observada" do que na presença dos atos e ações dela, ou seja, o "outro quarto", como pura alteridade, é a expressão daquela invisibilidade que pode ser preenchida pela imaginação: o que se observa no quarto ao lado, de mais importante, é a sua invisibilidade, seu velamento. Quando a alteridade anuncia-se, ela se apresenta como algo inominável, porque estamos, inclusive, dela afastados. Esse afastamento pode ser compreendido como a própria castração; trata-se de um afastamento inevitável, mas que pode ser modificado em função do estabelecimento de modos de posicionamento com a castração. Os sintomas, por exemplo, podem ser compreendidos, desse modo, como formas de dissimulação da castração, mas, além de certos sintomas, haveria formas de adoecimento psíquico em que esse afastamento parece ser intolerável. O Real, assim, torna-se assustador, um ponto ausente que não pode ser atenuado pela imaginação do que ocorre nele.

Na tragédia tebana de Édipo, há uma cegueira no final da peça, a qual pode ser compreendida como um sinal de castração (Freud, 1937/2006j). A cegueira de Édipo parece 
também a expressão de seu afastamento da cena primária, a expressão de que ele passaria a visualizar certos registros imagéticos que possivelmente não poderiam ser antes imaginados. Nesse ponto de vista, a castração assegura a continuidade da experiência com a vida mental, marcada pelo afastamento da invisibilidade da cena primária, que é novamente compreendida em função desse afastamento, ou seja, a partir da imaginação e da criação de fantasias que não permitem a permanência da pura alteridade no horizonte das experiências cotidianas infantis.

A visitação do Real, assim, é uma experiência de alteridade, porque efetua em nós aqueles movimentos que, simultaneamente, oferecem-nos o aparecimento de uma estranha diferença no ente e nos impossibilitam de figurá-la por inteiro. A alteridade conserva-se como diferença e não se transforma jamais em uma completa mesmidade. Como analogia, parece-nos que, desse modo, com a verdade, apenas poderemos ter os "sussurros", os "gemidos" e aqueles "barulhos" que nos deixam testemunhar a presença de certo Real que não nos aparecerá inteiramente, mas pela imaginação. Os "sussurros", os "gemidos" e os "barulhos" são demandas, desse modo, que nos exigem fundamentalmente ser. Nesse ponto de vista, o Real parece acontecer em nós também como uma demanda por existência mítica do eu mesmo, ou seja, por meio de ser expressão fenomênica de preconcepções que podem facilitar a relação com essa pura alteridade. Não há, por exemplo, como não nos lembrarmos do mito platônico da caverna, na qual os homens, que só viam sombras, estavam fundamentalmente impossibilitados de ver a luz do Sol. Podemos, assim, também dizer que o Real pode nos visitar não como pura luz do Sol, que faria queimar as retinas, mas como uma alteridade que possa ser apreendida, como, por exemplo, um casal parental feliz.

O “outro quarto", dessa forma, é aquela origem especular, em que podemos relacionarnos com a alteridade de modo que o Real apareça em nós mesmos como uma visitação ou um atravessamento, que pode ser apenas relativamente circunscrito pelo mito, mas cujas marcas 
haveremos de carregar ao longo de nossas vidas. Sobre isso, legou-nos Shakespeare (citado por Britton, 2003) tais versos, que poderíamos agora entoar:

\author{
E como a imaginação esboça \\ Uma forma para coisas desconhecidas, a pluma do poeta \\ As forjam, dando ao que é nada \\ Uma moradia e um nome. (p. 175).
}

\title{
5.2 Nas Bordas de Mundos sem Fim
}

No capítulo anterior, dedicamo-nos a descrever a estrutura preconcepcional do eu mesmo, cujo propósito pode ser o de tornar-se uma condição possibilitadora para o nascimento de pensamentos. A ilusão do eu mesmo, desse modo, quando visitado pelo Real, torna-se o lugar do acontecimento da quaternidade positiva embebida por sua contraparte negativa, de modo que as experiências do eu mesmo tornam-se marcadas pela presença da alteridade/diferença e, nesse sentido, de um não mesmo no eu mesmo, que é o acontecimento da alteridade/diferença na experiência emocional. Nosso propósito, neste momento, será falar sobre as bordas do eu mesmo, de como elas parecem formar um "espaço" de nascedouro de pensamentos que tende a ser um caminho de turbulência, com a visitação ou encarnação daquele Real que demanda ser.

\subsubsection{O Caminho da Tempestade}

Deixaremos, agora, que duas imagens surjam livremente, na esperança de que, por meio delas, possamos reunir e evocar aqueles elementos dispersos de nosso pensar que ainda precisam ser elaborados. O acontecimento do Real poderá ser suportado para que, em um estado de paciência, possamos desenvolver algo novo. Esse novo, assim, surge pelo desenvolvimento 
em forma de transformação do pensamento pela mente humana, mas pode nos trazer sentimentos de insegurança e instabilidade.

Em nossa nova evocação, gostaríamos de aglutinar sinteticamente, por meio de imagens, nosso saber sobre o Real, pois as imagens talvez possam manter-se como aquela janela vazada que pode nos despertar da fria presença dos objetos já conhecidos, significados e, portanto, esquecidos nas suas inimagináveis possibilidades. Com o Real poderá, incrivelmente, acontecer o mesmo. As imagens, nesse sentido, podem ser tanto transformações de "O" em imagens visuais quanto evocações para um caminho por meio do qual possa haver uma intimação e, posteriormente, uma encarnação de “O”.

Gostaríamos que essas imagens pudessem ter essa dupla via, pois, neste momento, surge-nos inevitavelmente o problema de se criar uma reunião daquilo que já foi pensado, para que possamos ir adiante. Será essa reunião um trabalho de rememoração de pensamentos já pensados? E isso acaso terá algum valor, se for tão somente uma compilação de informações, de pensamentos já pensados? Será expressão da operação da resistência? Ou será a síntese um indício de que, qualquer que seja essa compilação, a interrogação não chegará a um término, com algum tipo de resposta finalizante, conclusiva? Seja como for, o que tememos é que essa interrogação ininterrupta implique necessariamente uma turbulência e, quiçá, uma mudança que tende à própria catástrofe, ou seja, uma mudança ontológica pela ruptura com a experiência da mesmidade do eu mesmo, tal como indicamos anteriormente. No entanto, antes de sentirmos e discutirmos o sentido dessa catástrofe ou de realizarmos essa síntese, vamos às duas imagens.

A primeira imagem, de uma casa aturdida pela ameaça de uma terrível tempestade, parece ser quase que necessariamente antecedida pelos versos de um famoso poema de Tagore (1912), cujo primeiro foi relembrado por Winnicott (1971/1975) para formular sua concepção sobre a transicionalidade. Traremos, então, dessa imagem do poema em primeiro lugar. O poema encontra-se no livro Gitanjali, escrito por Tagore em 1912, e há um verso que muito 
impressionou Winnicott (1971/1975), tendo sido transcrito em seu livro $O$ brincar $e a$ realidade, no capítulo VII, no qual podemos ler: "Na praia do mar de mundos sem fim, crianças brincam.” (p. 133). Esse verso, que é o primeiro de um poema chamado À beira-mar (On the seashore), destaca o brincar que acontece na praia de mundos sem fim, intermináveis mundos, mas talvez não nos traga aquele sentido completo proposto por Tagore (1912), que seria talvez - sugerir que haveria algo mais ocorrendo enquanto as crianças brincam nessa praia de mundos sem fim. O seu sentido parece ter sido, portanto, profundamente compreendido e parcialmente modificado por Winnicott (1971/1975) ao dar destaque para o primeiro verso do poema.

Gostaríamos de poder ampliar essa discussão, apresentando, inicialmente, os três primeiros versos desse poema:

Na praia de mundos sem fim, crianças se encontram. O céu infinito

Está imóvel logo acima e a incansável água, tempestuosa. Na

Praia de mundos sem fim as crianças se encontram nos gritos e danças. (Tagore, 1912, tradução nossa). ${ }^{41}$

Nesse primeiro verso, precisamos dar destaque para a modificação do "brincar" para o "se encontrar"; há, no original, o verbo 'meet'. Esse verso, diferentemente do verbo 'play' (brincar, jogar etc.), indica que as crianças estão reunidas ou se encontram nesse lugar, nessa praia, mas que também é este o lugar de intermináveis mundos, de mundos sem fim. A

\footnotetext{
${ }^{41}$ O poema completo encontra-se em Gitanjali (Tagore, 1912), verso número 60, tal como reproduzido aqui: "On the seashore of endless worlds children meet. The infinite sky / is motionless overhead and the restless water is boisterous. On the / seashore of endless worlds the children meet with shouts and dances./ They build their houses with sand, and they play with empty shells./With withered leaves they weave their boats and smilingly float them/ On the vast deep. Children have their play on the seashore of worlds./ They know not how to swim, they know not how to cast nets. /Pearl-fishers dive for pearls, merchants sail in their ships, / While children gather pebbles and scatter them again./They seek not for hidden treasures, they know not how to cast nets./The sea surges up with laughter, and pale gleams the smile of the sea-beach./Death-dealing waves sing meaningless ballads to the children, even like/ a mother while rocking her baby's cradle. The sea plays with children, IAnd pale gleams the smile of the sea-beach./On the seashore of endless worlds children meet. Tempest roams in the pathless sky,/Ships are wrecked in the trackless water, death is abroad and children play./On the seashore of endless worlds is the Great meeting of children."
} 
modificação de "se encontram" por "brincam" faz todo o sentido no decorrer do poema, embora, com essa substituição, deixemos de apreciar que Tagore (1912) indica-nos que é por meio desse encontro, nesse lugar e dessa forma (brincando) que as crianças justamente se encontram. Podemos prosseguir nossa leitura do poema para entender melhor isso:

Elas constroem suas casas com areia e brincam com conchas vazias.

Com folhas murchas fazem seus barcos e - sorridentes - flutuam-nos

Na profunda vastidão. Crianças brincam na praia de mundos.

Elas não sabem como nadar, elas não sabem como lançar as redes.

Pescadores de pérolas mergulham por pérolas, mercadores vendem em seus barcos,

Enquanto crianças juntam seixos e espalham-nos depois.

Elas não procuram tesouros perdidos, elas não sabem como lançar as redes.

O mar - rindo - se desfaz e reflete um pálido sorriso na orla do mar.

Ondas mortíferas cantam baladas sem sentido para as crianças, como

A mãe, enquanto balança o berço de seu bebê. $\mathrm{O}$ mar brinca com as crianças,

E reflete um pálido sorriso na orla do mar.

Na praia de mundos sem fim, crianças se encontram. A tempestade vaga no céu intransitável,

Navios naufragam na água sem deixar rastros; morrem no estrangeiro, enquanto as crianças

[brincam.

Na praia de mundos sem fim elas vão se encontrando grandiosamente. (Tagore, 1912, tradução nossa).

Com suas danças e por meio de suas falas ou gritos, elas se encontram. Fazem casas ou abrigos frágeis, feitos de areia; como barcos feitos de folhas murchas que vagam no mar, elas flutuam na vastidão profunda do céu e do mar. Elas fazem os seus mundos nas bordas de outros e se encontram consigo mesmas e com os outros nessa borda, por ser borda. Elas se encontram porque se juntam umas às outras e se encontram porque é assim que percebem a si mesmas. Elas se encontram no brincar. Elas brincam na praia de mundos criados por elas. Nessa apresentação do encontro das crianças consigo mesmas, não nos fica difícil conceber que o 
espaço em que se podem criar mundos sem fim é justamente o espaço aberto da quaternidade positiva, com suas bordas porosas e instáveis, como o céu e o mar parecem estar nessa bela imagem do poema. Nesse espaço, há um acontecimento peculiar, o da criação brincante, em que se juntam e desfazem seixos, que põem seus barcos frágeis a flutuar na água profunda.

Ondas mortíferas, água tempestuosa, a tempestade que vaga... Mais além, nesse mar, mar estrangeiro, há a morte. As crianças brincam ao lado de ondas mortíferas que se desfazem na orla do mar com sorrisos pálidos, espumas que chegam às bordas de seus mundos sem fim. Enquanto brincam, elas criam e se encontram, encontram a si mesmas, encontram as outras crianças e encontram seu mundo também, um mundo positivo, de paternidade, terra, coisas e pessoas, mas estão na beira-mar, na praia, e, além dos mundos criados, há uma borda com o profundo do mar e o profundo infinito do céu. Há um mar tempestuoso e um céu tempestuoso, intransitável e cheio. Há um risco para as crianças, um risco de tudo aquilo que virá desse infinito, mas, nesse lugar arriscado, há também o lugar, o próprio lugar em que elas se encontram, em que elas são crianças e estão reunidas.

Acaso a inclusão do seu final, desse anunciar do imóvel, preparando-se para um acontecimento, da água turbulenta, tempestuosa, talvez da tempestade que se aproxima, não nos fornece uma nova pista sobre a relação entre a transicionalidade e o Real? Pensamos que sim. É importante relembrarmos que Winnicott (1971/1975), ao se interrogar sobre o brincar, pensou que ele não era oriundo de uma realidade psíquica interna tampouco de uma realidade externa. A sua pergunta sobre em qual região - ou em qual mundo ou registro, poderíamos dizer ocorre a brincadeira aproximou-se de uma questão no mínimo intrigante: a de que há um campo de acontecimentos peculiar, no qual "encontrar" um objeto e "criá-lo" são o mesmo. Essa experiência de criatividade e de brincar é produzida pela capacidade de se obter um sentimento de confiança com a mãe, ou com a família ou com a sociedade ou com o mundo, o qual está ligado à ilusão de que existe uma realidade externa correspondente à capacidade de imaginar e 
de criar. A confiança surge pela possibilidade de experimentar uma continuidade nessa experiência de ilusão criadora, da qual obtemos profundos sentimentos de presença de vida e segurança. No entanto, antes de prosseguirmos nessa direção, gostaríamos de sugerir uma nova imagem.

Essa nova imagem oferece-nos uma continuidade em relação a esses profundos versos de Tagore (1912) e foi extraída de um romance de Henri Bosco, chamado Malacroix, tendo sido citada e discutida por Bachelard (1957/1989), em seu livro A poética do espaço, que dedica belas páginas a seu respeito. Pensamos que as imagens, em continuidade, podem nos contar a história da relação entre a ilusão do mito do eu mesmo e o afrouxamento das suas bordas pelo acontecimento do Real. Vamos a ela:

A casa lutava bravamente. A princípio ela se queixava; as piores rajadas a atacaram de todos os lados ao mesmo tempo, com um ódio nítido e tais urros de raiva que, durante alguns momentos, eu tremi de medo. Mas ela resistiu. Quando começou a tempestade, ventos mal-humorados dedicaram-se a atacar o telhado. Tentaram arrancá-lo, partir-lhe os rins, fazê-lo em pedaços, aspirá-lo. Mas ele curvou o dorso e agarrou-se ao velho vigamento. Então outros ventos vieram $\mathrm{e}$, arremessando-se rente ao solo, arremeteram contra as muralhas. Tudo se vergou sob o choque impetuoso; mas a casa, flexível, tendo-se curvado, resistiu à fera. Sem dúvida ela se prendia ao solo da ilha por raízes inquebrantáveis, e por isso suas finas paredes de pau-a-pique e madeira tinham uma força sobrenatural. Por mais que atacassem as janelas e as portas, pronunciassem ameaças colossais ou trombeteassem na chaminé, o ser agora humano em que eu abrigava meu corpo nada cedeu à tempestade. A casa apertou-se contra mim, como uma loba, e por momentos senti seu cheiro descer maternalmente até o meu coração. Naquela noite ela foi realmente minha mãe. Eu só tinha a ela para me proteger e amparar, estávamos sozinhos. (Bosco, citado por Bachelard, 1957/1989, p. 61).

Poderíamos, naturalmente, conceber a tempestade que se forma na praia de mundos sem fim dirigir-se e acontecer, em uma noite escura, na morada do autor. Somos convidados a acompanhar essa continuidade. Essa frágil morada vai se transformando naquela morada que permite a experiência do temor da catástrofe, do desmanche da pequena casa, pois é uma 
morada que se verga, que é maleável o suficiente para acompanhar a irrupção daquilo que ocorre fora dela, sem sucumbir. Nessa casinha profundamente enraizada, não sabemos mais diferenciar nitidamente o dentro e o fora, pois não se trata de uma casa alheia às terríveis condições de fora dela, mas é uma casinha esburacada, uma casinha que abriga e que se mantém permeável, tal como os buracos da teia de aranha. Enquanto, nos versos de Tagore (1912), as crianças parecem estar alheias às ameaças do céu e das águas turbulentas, a casinha de Bosco (citado por Bachelard, 1957/1989) sofre a iminência da catástrofe. Ameaças colossais são dirigidas àquilo que abriga e, simultaneamente, ao abrigado.

Há, nessa passagem, um anseio por terra, por morada e por paternidade que as crianças que brincam na praia de mundos parecem simplesmente realizar, ao se manterem confiantes, brincando na areia, sem o medo pelo desastre que bate à porta. Mas nosso narrador, por alguma razão inexplicável, pode nos descrever linhas verdadeiramente poéticas repletas de analogias e criatividade diante dessa situação. $O$ desastre parece ser poder perder aquilo que lhe abriga e a destruição de seu próprio abrigo. Com esse acontecimento de ser atravessado pela possibilidade da catástrofe do desterro, há um intercâmbio com a negatividade do Real e com as marcas da orfandade, que se tornam presentes em sua relação com a casa, mas podemos notar que o temor se dirige, principalmente, à possibilidade do desastre de sua própria pessoalidade.

Essa linda imagem ainda nos oferece a possibilidade de sentirmos a profunda ligação do narrador com a casa, que vai aos poucos se tornando uma casa viva, uma casa humana, um objeto lírico e um ser humanizado, que mantém um diálogo com aquele que abriga, por meio de seus apertos, dos seus cheiros, de sua força e também da sua solidão. A casa parece ansiar por ele e ele, pela casa e, na solidão recíproca, ambos se apertam, conversando na iminência da catástrofe. Essa atitude dialógica, que não deixa de manter presente essa condição de precariedade, pode também manter vivo um sentimento de esperança no porvir. Gostaríamos de 
destacar justamente a importância dessa atitude dialógica, de esperança e segurança sob a face do Real.

Nessa passagem, podemos compreender, também, que a iminência da catástrofe deixa todo o ambiente temeroso, preparado para um desastre próximo, que não vem. Esse temor, esse medo, procura representar a tempestade como aquilo pelo que se atemoriza. No entanto, lendo esse trabalho com bastante atenção, podemos compreender que essa tempestade é aquilo que coloca o narrador em estado de desespero, porque parece nos dizer que, caso a tempestade realize sua tarefa, ela produzirá aquilo que é realmente assustador: o desterro e a orfandade; percebemos isso no final de sua descrição e torna-se mais claro se pudermos perceber a atitude dialógica que o narrador estabelece com a casa. Entretanto, sabemos que a orfandade e o desterro não são senão aqueles anseios não realizados e, assim, estão presentes enquanto o narrador conta a sua história - de ter uma casa e uma mãe. Paradoxalmente, enquanto ele narra a sua história, cria, com sua narrativa, aquela casa-mãe que podia ser criada por ele - também porque ela estava lá disponível para ser criada.

Essa atitude dialógica, tal como sabemos, é aquela presença fundamental do trabalho clínico, tão indiscutivelmente valorizada e comentada que parece, por vezes, tornar-se uma coisa comum e, assim, esconde-se naquilo que permanece ainda velado, pois a importância do diálogo é tamanha que podemos considerá-lo o princípio fundamental do acontecimento clínico psicanalítico. Acaso a psicanálise não nasceu com a atitude freudiana de escutar e conversar com os seus pacientes? Nos casos em que há um distúrbio desse diálogo, podemos notar simultaneamente sua impossibilidade de ocorrer no próprio interior discursivo do ser humano. Percebemos, por essa passagem, que a atitude dialógica não se dirige a uma casa dura, de segurança plena, de bordas firmes, impenetráveis; a casa é sujeita ao desabrigo, assim como o narrador, e ambos podem sucumbir. 
A atitude dialógica em relação ao Real também ocorre, como observamos anteriormente no aparecimento da alteridade/diferença, que também teria essa característica quando pode ser aquela presença que não se deixa capturar e, simultaneamente, mantém vivas a interrogação e a exuberância do ente, promovendo justamente essa atitude de diálogo incessante. Na relação dialógica com a casa, não poderíamos dizer que, com ela, criam-se mundos sem fim? Acaso não se torna o escritor uma criança amparada por sua mãe, pertencente a uma morada que lhe protege, porque se mantém nessas bordas que fazem aparecer a ausência de morada e a orfandade? Há uma permanente sensação por parte do leitor de que o autor desse lindo trecho pode estar se iludindo sobre como a casa protegeu-o, mas, simultaneamente, somos convidados a testemunhar que essa ilusão aparece nas bordas de uma situação absolutamente precária, de profunda instabilidade e insegurança. Trata-se daquele anseio por terra e por paternidade, que discutimos anteriormente, reaparecendo aqui representado por essa figura da casa. Isso não nos é uma ideia nova, mas nos remete para um problema central: a ilusão que ocorre diante da precariedade não tende a se desfazer quando aquilo que nos deixa precários exige que nós nos tornemos também essa precariedade?

Heidegger, que sempre nos auxiliou nos momentos incertos de nosso trabalho, talvez não se furte neste momento, ajudando-nos a ampliar essa discussão, como nessa passagem de seu trabalho A essência da linguagem (1959/2004), que nos oferece um belo trecho relacionado com essa questão:

Pensando com mais rigor, o caminho é que nos permite alcançar o que nos alcança, o que nos lança uma intimação [...]. A intimação: aquilo que alcançando nossa essência a exige, vai ao seu encalço e assim alcançando permite-lhe alcançar o lugar a que pertence. (p. 154).

Pois aquilo que nos intima vem ao nosso encontro na ilusão, desfazendo essa mesma ilusão, quando percorremos o caminho do cuidado, em que alcançamos gradativamente aquilo 
que nos intima. Parece-nos, assim, que essa terceira imagem capacita-nos a ampliar esse sonho da tempestade, incluindo agora um novo elemento: o caminho da tempestade. Entendemos, desse modo, que o trabalho clínico pode ser identificado também como um caminho da tempestade, muito embora possa ser simultaneamente considerado aquele abrigo que permite a apreensão do que ocorre fora da casa, do Real, como algo diante do qual se queira proteger, na ilusão. Mas a ilusão seria a possibilidade de criarmos e pensarmos aquilo que ainda não foi criado ou pensado dessa relação com as bordas de mundos sem fim ou seria o fechamento ou tamponamento do pensar e do criar? Pois a ilusão da transicionalidade parece nos remeter a um campo de experiências em que há, continuamente, a criação ou o aparecimento da alteridade/diferença no brincar e nos objetos transicionais. A descrição de Bosco (citado por Bachelard, 1957/1989) não seria uma atividade transicional?

Esse caminho da tempestade é o preparo cuidadoso para que alcancemos aquilo que pode nos alcançar e, quando nos alcança, lança-nos a intimação de sermos atravessados por essa visitação. O caminho da tempestade é o caminho que alcança a turbulência que vem ao nosso encontro. O trabalho clínico, nesse sentido, é um caminho cuidado e preparado para as turbulências, mas podemos nos enganar pensando que a preparação deva ser um fechamento, tal como uma casa imune às tempestades; por isso a descrição de Bosco (citado por Bachelard, 1957/1989) deve ser tão atentamente lida.

Nessa descrição, essa visitação é violenta e forte, causa medo e, também, turbulência; ela se refere, portanto, a algo parecido com uma mudança catastrófica. Esse termo, usado por Bion (1970/1991a), em seu trabalho A atenção e interpretação, diz respeito provavelmente àquela transformação que atinge a própria "divindade", ou seja, àquilo que não depende de base sensível. As transformações em “O”, ou seja, as transformações que têm como origem a possibilidade de aparecimento da alteridade/diferença em sua radicalidade, têm sempre um caráter disruptivo por conduzirem a uma abertura do eu mesmo, tornando porosas as bases 
sensíveis nas quais se apoia a experiência de mesmidade. Uma mudança catastrófica, isto é, a experiência da irrupção do Real na personalidade, até então marcada sob o prisma da mesmidade, é a expressão daquela emanação e encarnação infinita e informe (Bion, 1970/1991a). O infinito e informe é o próprio Real, que anseia ser continuamente um ato positivo de ser, ou seja, uma transformação, um pensar.

Bion (1965/2004a) usa para essa descrição alguns versos, como, por exemplo, de John Milton, que, em seu poema $O$ paraíso perdido, descreve:

Ó nascente mundo de profundas, obscuras águas;

Arrebatado ao infinito vazio e sem forma. (p. 176).

Há um mundo nascente, que provém de águas ou regiões obscuras. Ele nasce, tal como um pensar, dessas regiões obscuras, arrebatadas do infinito. Um mundo nascente traz consigo sua origem, essas obscuras regiões de seu nascimento, e, mesmo que se torne nascido e forte, um pensar poderoso, guardará continuamente sua remissão a essas obscuras regiões de mundos impensados. Dito de outro modo, esse mundo (pensamento) nascido deverá continuamente nascer e, à medida que nascer, ele se ampliará, sem que, no entanto, chegue a totalizar-se, completar-se, pois possibilitar existir um mundo nascente é o resultado do trabalho dialógico da clínica psicanalítica. Uma "verdade emocional" é a parteira de mundos de obscuras águas, de ideias novas, e não (de) um conteúdo definitivo do pensar.

\subsection{2 Águas Turbulentas, Força Disruptiva}

A visitação do Real acontece como aquela intimação que suscita a alteridade/diferença. Como algo infinito e informe pode produzir um acontecimento disruptivo? O interesse por essa pergunta certamente não está em sua resposta, mas na possibilidade, neste momento, de nos 
mantermos inquietos perante ela, pois, se nosso trabalho clínico for um trabalho de preparação ou cuidado para o caminho da tempestade/turbulência, então pensamos que, primeiramente, ele parece ser um caminho de desilusão gradual para uma intimação não programada; também pensamos que a psicanálise cuida pelo aparecimento da alteridade/diferença, que não é, no entanto, somente um aparecimento, mas a realização que nos torna aqueles elementos ou qualidades ainda não desenvolvidos pela personalidade; e, ainda, que esse trabalho implica uma mudança catastrófica para o eu mesmo, arrebatado pela obscuridade que se faz resplandecer com o desenvolvimento de qualidades novas, descobertas e evoluídas, destronando o eu mesmo de seu posto aparentemente unitário e centralizador.

Bion (1962/1994c), em seu artigo Uma teoria sobre o pensar, formula a tese, já exposta anteriormente, de que o pensamento é a união de uma preconcepção com uma frustração. Essa ideia parece ser a mesma que estamos procurando expor neste momento, pois nela há presente, com a ideia de frustração, a presença de um fosso criado entre o anseio e a sua realização. Assim, aquilo que é infinito, vazio e sem forma pode criar o estado fundamental para que algo como um pensar possa começar a se desenvolver nesse fosso. Aquilo que nos intima é, nesse contexto, o estado de abertura, que não é, fundamentalmente, nenhum ente, nada de especial, no sentido de que não é uma coisa, algo estabelecido ou um conteúdo mental; o que parece interessante nesse sentido é pensar que a encarnação de "O", para o autor, é a encarnação de um infinito vazio que anseia por tornar-se e que põe o aparelho para pensar em atividade, com o intuito de realizá-lo. O Real, assim, acontece como o anseio que demanda, pois é fundamentalmente um infinito sem forma e vazio, que procura realizar-se por meio de nossa capacidade de tolerar sua presença disruptiva. A intimação do Real vai a nosso encalço e permite que, por meio dela, alcancemos justamente aquilo que nos é exigido, por meio de um pensar peculiar, de uma experiência emocional do pensar. 
Mas voltemos ao caminho da tempestade. A preparação para a turbulência pode estar associada, em certo sentido, com a possibilidade humana de ser aquele "lugar" onde as tempestades acontecem. Essa preparação articula-se com aquela promovida pela angústia, no sentido de que revela a irrupção da alteridade/diferença associada com a atenção, que é o estado de mente paciente que não precisa, de um modo sôfrego, ansiar por realização imediata e, assim, conserva-se consciente e tolerante mesmo diante de uma situação ainda incerta, à espera de um novo fato, ideia ou razão, que indique o padrão que evolve de “O” (Bion, 1970/1991a).

Como representação gráfica desse lugar em que acontecem tempestades, podemos nos lembrar de certos desenhos de Leonardo da Vinci, em que figuras desenhadas com água forte apresentam cabelos revolvidos como águas turbulentas. Podemos observar, no Busto de homem grotesco de perfil virado para a direita (1505) ou na Jovem mulher apontando lady (1516), essas mesmas representações. Esses cabelos, que estão além das bordas do corpo, da cabeça humana, permanecem como aquilo que ainda não foi tornado parte da personalidade, revoltosos como águas turbulentas e tumultuosas, e como "pensamentos sem um pensador". Bion (1976/1985) descreve-os como expressões de estados de turbulência emocional; já pela teoria das funções, poderíamos dizer que se tratam de elementos beta ainda não transformados. No entanto, de outro ponto de vista, podemos hoje, muito tempo depois de esses desenhos terem sido produzidos, envolver-nos com eles, de modo que eles possam evolver segundo um padrão - o das águas tumultuosas -, que nos faz uma remissão ao assombro e reverência por podermos reconhecer neles a presença inefável de aspectos não transformados de nossa personalidade. Podemos nos espantar com aquilo que poderia ser representado como algo que escapa da nossa possibilidade de representação e torna-se apenas um modo de fazer uma remissão icônica àquilo que não poderá ser traduzido ou representado, ao Real.

O espaço em que ocorrem tempestades é aquele que possibilita a manutenção do cuidado com o caminho que nos conduz àquela intimação que nos chega e que nos demanda 
ser. Essa intimação é promovida pelo Real, mas, para a personalidade, ela não é somente um alimento para o desenvolvimento da mente; quando surge como uma nova ideia, ela contém uma "força potencialmente disruptiva e que violenta, em maior ou menor grau a estrutura do campo em que se manifesta.” (Grimberg et al., 1973, p. 38). Essas ideias disruptivas parecem ser necessariamente um caminho de dupla via: serem transformações que evolvem do Real e também serem formas de remissão ou encaminhamento para o Real. Poderíamos, assim, representar isso do seguinte modo: forma icônica $\leftrightarrow$ Real; isso porque a forma icônica, mesmo como forma, parece manter-se porosa, assinalando enigmaticamente a presença disruptiva do Real. Os cabelos tumultuosos, como lugar em que ocorrem as tempestades, nas bordas de fora da personalidade humana, parecem demonstrar isso, mas, potencialmente, qualquer ideia ou ente que se mantenha aberto ao Real, inacabado e pertencente às bordas do acontecer humano pode ter essa dupla via. Os fatos clínicos psicanalíticos parecem ser, especialmente, fatos de dupla via.

Por outro lado e concomitantemente, é preciso ressaltar que Bion (1962/1991b), ao formular a ideia da teoria das funções, ao tratar dos elementos alfa, não pretendeu com isso dizer que haveria algo concreto na mente humana produzido sob a forma de elementos alfa, mas justamente que os elementos alfa seriam a transformação de elementos sensoriais em algo que se torna disponível para ser fonte de pensamentos, sonhos ou memória, ou seja, algo não sensorial. O não sensorial é, simultaneamente, aquele elemento que se transformou em não sensorializado pela função alfa e aquilo que permanece presente em um dado sensorial simples e que pode desvelar que esse elemento sensorial possui uma forma icônica de remissão ao disruptivo. O desenho dos cabelos tumultuosos, por exemplo, é produto de uma transformação de elementos beta, sensoriais, em elementos alfa, que se tornam disponíveis para a criação daquilo que nos remete justamente ao inefável. $O$ inefável é o Real, um inefável presente no campo da experiência, que, por sua vez, mantém-se como aquela presença que escapa e que 
irrompe pela alteridade/diferença da sensorialidade. Assim, por meio das transformações realizadas pela função alfa, podemos encontrar o não sensorial, que é justamente o estado de abertura e disponibilidade para que a alteridade/diferença possa acontecer inesgotavelmente.

Quando pensamos que a tarefa psicanalítica pode ser útil para disponibilizar o paciente a se manter no caminho da tempestade, isso quer dizer que parece ser importante essa atitude de cuidado por meio do desenvolvimento da capacidade de pensar. Os pensamentos, criados ou revelados por meio de uma função alfa, que pode ser originada das condições mentais do próprio analista, possibilitam que aquele campo de experiências não sensoriais possa se expandir e, com isso, também a ampliação da visão de que os fatos experimentados não só provêm de uma ausência de forma, como são remissões para esse mesmo inefável da experiência. O caminho da turbulência é, assim, o caminho da desilusão.

Por ilusão, como já sabemos, tratamos de todas aquelas experiências que tendem a se tornar fatos reais da experiência, como, por exemplo, ter uma casa, nacionalidade ou pátria, ser filho, estar sempre acompanhado e possuir objetos, ideias ou palavras. A transicionalidade, no entanto, implica um franco diálogo com a alteridade/diferença e, de certo modo, é marcada por sua presença, que recria e reconhece o novo naquilo que já estava lá. Assim, esperamos que o caminho da turbulência/tempestade possa ser aquele caminho do reconhecimento da presença ausente e enigmática do Real na existência humana; sua visitação apenas nos indica, de modo geral, como somos bem pouco hospitaleiros para aquilo que está fadado a ser sempre e inevitavelmente estrangeiro. Como nos diz Whitman (1855/1983):

Desconhecido, se você vier passando e der comigo e quiser me falar, Por que não há de falar comigo?

E eu, por que também não haveria de falar com você? (p. 17). 
Nossa discussão sobre o Real na clínica psicanalítica encontra, neste momento, um problema que merece ser superado. O trabalho da função alfa mostrou-nos que ela produz uma modificação de um estado bruto, ou de elementos beta, em elementos a serem armazenados e que, posteriormente, formam o material de sonhos, pensamentos e elementos que podem ser usados por nossa vida mental. O Real, nesse sentido, não parece se identificar com o próprio elemento alfa, com as transformações realizadas pela função alfa dos elementos que foram metabolizados ou com a coisa em si transformada pela mente. Ele parece justamente se tornar mais arredio quando podemos pensar, uma vez que as transformações que fazemos dele pelo nosso pensar conduzem-nos, pelas próprias transformações do pensar, para mais longe dessa fonte desconhecida originária. Nessa perspectiva, imaginamos uma mente que apenas pode pensar criando desacordos com a realidade desconhecida, sobrepujando-a e designando fenômenos que são transformações do original e, também, inevitáveis falsificações para que o Real possa ser pensado. Nesse contexto, há um problema relacionado com a nomeação, com a representação, que diz ser aquilo sobre o que assinala. Mas, enfim, perguntamos: será essa a verdadeira ação do pensamento? E, principalmente, da experiência emocional na clínica psicanalítica?

\subsubsection{A Catacrese e o Centro Fugidio}

O problema parece ser incrivelmente amplo. Encontramos em algumas poesias de Wallace Stevens (1950), em especial, em Um primitivo como um orbe (A primitive like an orb), um meio de demonstrar justamente que o pensar pode se dar na direção contrária, ou seja, a de assinalar que aquilo sobre o que se pensa mantém-se para nós justamente como a manutenção da presença de um centro fugidio que não pode ser nomeado diretamente. Veremos o motivo disso, mas, nesse sentido, a ação da função alfa seria a de conservar o centro em aberto, sem que 
seja desfigurado por meio de uma tentativa mentirosa de representação da totalidade daquilo que se diz, de nomeação e tamponamento desse centro fugidio.

Nesse poema, extraído de The auroras of autumn (1950), há uma bela tentativa realizada pelo poeta de transmitir a pujança ou o vigor de uma experiência, quando não de procurar dizer concreta ou inteiramente (caso fosse possível isso) o que ela é. Assim, ao longo do poema, somos convidados a permanecer, simultaneamente, atordoados por um sem-número de imagens e representações para aquilo que o poeta tenta dizer e sempre endereçados, pela própria estrutura do poema, a algo mais que ainda não foi dito e que precisaria ser dito para nos esclarecer melhor aquilo que está sendo transmitido. Stevens (1950) realiza, assim, uma espécie de catacrese em todo o poema, tal como nos aponta Miller (1995), ou seja, indica-nos que há uma impossibilidade de figuração daquilo que pretendia falar; desse modo, ele procura criar, nesse belo poema, vários tipos de imagens, com a tentativa de aproximar seu leitor daquela experiência que o originou, da qual o poema fala. Essa catacrese é, assim, mais do que uma figuração pela falta de um termo próprio, visto que, na verdade, aquilo do que o poeta fala é o Sol - e há um termo ou uma palavra para designá-lo, ou mais do que um -, mas um Sol que deveria ser escrito como $\$ 61$, tal como nos indica Miller (1995). Nesse sentido, podemos dizer que 61 (ícone) $\leftrightarrow$ Real. Talvez esta seja uma forma de representar uma palavra quebrada, que se desapegue de seu aspecto de sensorialidade fechada em si mesma, para uma abertura para aquilo que há além dela mesma. Designá-la como cortada não significa, no entanto, apagá-la. Pensamos que esta talvez possa ser uma apresentação do propósito de Bion (1976/1985) de que pudesse haver uma formulação do fenômeno que estivesse o mais próximo possível do nômeno.

Voltando ao poema; nele, Stevens (1950) mostra que a própria linguagem parece ser uma espécie de catacrese, uma tentativa de figurar termos que se aproximem daquilo que não tem possibilidade de nomeação, ou seja, da coisa em si. Ao realizar esse intento, ele nos mostra que, na profusão de nomeações e designações para esse centro ausente, centro para o qual não 
há uma nomeação específica, pois se trata acima de tudo de uma experiência inefável de Sol, mantemo-nos abertos para a experiência do poema e disponíveis para algo que vai se formando em nós, justamente como a desconhecida experiência emocional de um Sol, portanto, uma experiência de abertura ao Real. O poeta parece demonstrar como as palavras podem ser enganosas, quando nos iludem em relação à sua capacidade de representação de uma experiência, mas, na verdade, tornam-se concretas, coisas duras, que limitam justamente a experiência para a qual podem estar em remissão - casos em que o aspecto sensório da palavra pode tomar conta da experiência.

A importância desse poema reside na possibilidade de ele nos manter abertos à experiência do velado, daquilo que não se deixa capturar por uma nomeação apressada, envolvidos por imagens sem fim que necessariamente deixam escapar o fundamental e sempre se mantêm como remissões para além daquilo que já foi nomeado. Ou seja, como podemos, por meio das palavras, por meio de aspectos sensórios e com a ajuda deles, aproximarmo-nos daquilo que é inefável na experiência? O poema de Stevens (1950) parece ser um exemplo disso: movimenta-se de modo circular, mas de forma a criar sempre enigmas e figurações incompletas para aquilo que demanda tradução, mas que não poderá ou não deverá ser traduzido inteiramente: uma sedução que nos conduz ao esquecimento do centro fugidio. ${ }^{42}$ Assim, em certo momento, ele nos diz: "In the instant of speech,/ The breadth of an accelerando moves/ Captives the being, widens - and was there [E no instante da fala/ O sopro de um acelerando se move/ Cativa o ser, se alarga - e estava lá!]”. Ou seja, ele nos indica que aquilo que nomeia é transitório, fugaz, que as palavras que tentam nomeá-lo perdem-se no tempo de uma experiência passageira. Mais do que isso: o nomear ou o dizer não pode querer designar algo da ordem da experiência sem que tenha de testemunhar seu fracasso em ser não

\footnotetext{
${ }^{42} \mathrm{O}$ método palimpséstico presente neste trabalho parece ser, de algum modo, análogo a este, tal como descrito nessa passagem: movimentando-se de modo circular, reencontra diversas vezes o mesmo, que se revela em vértices distintos e vai em direção a uma origem não figurada. Relembramos, assim, aquela frase de Bachelard (1989, p. 217): “Que espiral é o ser do homem!" E podemos completá-la dizendo: que espiral parece ser o ser esburacado do homem!
} 
mais um “é”, mas um "foi” ou um "estava lá". Nessa transitoriedade, o poeta mostra-nos que há sempre uma atitude do pensar que tende a querer congelar a experiência por meio das palavras e que parece ser malsucedida quando pretende dizer uma experiência emocional, que, tal como esse poema convoca-nos a ter, mantém-se inefável, porque guarda em si sempre a possibilidade de estar em transformação e, nas transformações, resguardar seu centro fugidio, que não se deixa tamponar por uma figuração que promova o seu esquecimento.

Ao pensarmos sobre a função alfa a partir desse poema de Stevens (1950), somos levados a considerar que ela pode ser compreendida como uma função cujo propósito é manter a mente disposta para a apreensão da realidade psíquica palimpséstica, ou seja, por meio da função alfa, há uma transformação da realidade desconhecida em um dizer, que não se diz por inteiro. A sua função parece ser a de produzir elementos permeáveis, capazes de serem reorganizados ou combinados de modo a permanecerem assinalando um centro fugidio. Assim, as palavras e suas designações podem se combinar com outras palavras e outras designações infinitamente, mantendo-se sempre abertas para aquilo que perseguem: um movimento de um pensar que não se paralisa e permanece sempre em devir. Cada palavra que nomeia o Sol, por exemplo, não é a completa nomeação da experiência de Sol, mas pode se aproximar daquilo que é essa inominável experiência de Sol. Essa aproximação dá-se justamente no silêncio, naquele sentimento do não dito - não porque esteja recalcado, mas porque não se encontram modos de dizê-lo inteiramente -, na própria experiência ou, melhor dizendo, no inefável da experiência. É justamente isso que resguarda o centro fugidio. Quando o centro fugidio mantém-se presente, mas silencioso, haveria algo como uma experiência sacra. Poderíamos nos lembrar dos versos de Ungaretti (2003), que dizem:

Di questa poesia

Mi resta

Quel nulla 
D'inesauribile segreto. (p. 43). ${ }^{43}$

O pensar psicanalítico pode ser um pensar que persegue esse centro fugidio, mas se empobrece quando pretende substituí-lo por uma palavra definitiva sobre a realidade psíquica palimpséstica. Portanto, os fatos clínicos psicanalíticos serão sempre faxos. Sua tarefa investigativa pressupõe justamente que essa perseguição não seja finalizada e que possa ajudar o analisando a reconhecer o centro fugidio da experiência que nos escapa constantemente, ainda mais quando pretendemos impacientemente designar e finalizar um movimento que é interminável. Freud (1900/2006b), quando recomendou voltar para um sonho posteriormente para continuar a interpretá-lo, já havia indicado que esse movimento deixa escapar muito de uma realidade psíquica desconhecida. Há um inacabável, um inesgotável, que não se deixa apreender, por ser inapreensível. Mas não seria esse inapreensível, ou esse inefável, justamente o Real? Pensamos que sim, mas sabemos que esse inapreensível é inapreensível porque não se esgota em alguma proposição. Ele, no entanto, é aquele silêncio que busca se tornar permanentemente palavra, aquele silêncio sacro, em que podemos testemunhar a exuberância e a pobreza da palavra, que explicita e revela, e que oculta e priva em seu dizer. Desse silêncio sacro, a palavra imprópria e cambaleante assinala seu centro fugidio. As palavras do analisando são ecos do Real; as do analista são convites para um reencontro. Enquanto isso, o Real a ambos intima.

Podemos dizer, neste momento, que o padrão que evolve do Real, na espera de um fato selecionado, tal como fora descrito por Bion (1962/1991b), é justamente a verdade transitória e exuberante que pode existir numa palavra e, simultaneamente, o silêncio de um centro fugidio que se evade de nós. Esse centro fugidio é a direção que tomamos, na perseguição pela verdade, quando sustentamos o desabrigo que o ritmo do movimento de instabilidade da verdade transitória impõe-nos. A verdade transitória, marcada pela

\footnotetext{
43 “Desta poesia/ me sobra/ aquele nada/ de inesgotável segredo." (Ungaretti, 2003, p. 43).
} 
instabilidade da irrupção da alteridade/diferença, é a expressão do não mesmo no eu mesmo. O eu mesmo, desse modo, é como um mito de um caminho da tempestade, que poderá manterse aberto para o silêncio sacro do centro fugidio da tempestade, enquanto as transformações do pensamento vão sendo feitas com as marcas dessa diferença/alteridade pela realidade psíquica palimpséstica, como transformações do pensar.

No início deste trabalho, havíamos feito uma citação do poeta italiano Giuseppe Ungaretti (2003), que comentava sobre o título de seu livro Il porto sepulto. Nessa passagem, ele nos descreve como havia um único sinal - um porto conservado no fundo do mar -, um único documento do que haveria sido Alexandria - a sua cidade natal -, antes mesmo do início daquilo que se considera o princípio dos registros sobre ela. O trabalho da função alfa, nesse sentido, pode ser descrito como o da elaboração e escrita a partir dos sinais e dos registros que são indicados para a dupla analista-analisando. Essa elaboração permite que os sinais possam ser transformados em histórias narradas, em histórias de desastres (como a lenda da cova da morte e do sepultamento real, de $U r$ ) ou em histórias que não puderam ainda ser contadas, para serem justamente transformadas em registros inconscientes. $\mathrm{O}$ trabalho da função alfa, assim, pode ser compreendido como o trabalho de efetuar registros palimpsésticos, de transformar sinais, centro fugidio (pensamentos sem um pensador), em histórias, em registros, na formação de camadas sucessivas de pensamentos oníricos que poderão permanecer disponíveis para a vida mental.

Podemos pensar que o caminho da tempestade, tal como o descrevemos aqui, reside na possibilidade de apreensão de que o mito do eu mesmo, no qual se inscreve a realidade psíquica palimpséstica, situa-se nas bordas de mundos sem fim, que são intermináveis mundos constituídos como tessituras de uma grande teia de aranha. Essa teia, por sua vez, abriga-nos da tempestade, que está ocorrendo aparentemente fora de nossa casa, sempre marcada pela possibilidade - não concreta, não sensorial - do desterro, da solidão, do nada e 
da orfandade. Ao ser tolerada, podemos criar e revelar mundos sem fim, quando transformamos essa tempestade em palavras que possam conservar a pujança da experiência, que é tudo aquilo que há nessa experiência que não foi ainda tornado palavra, fato ou existência. A tolerância está marcada pela possibilidade de suportar essa incompletude da palavra e pela manutenção desse centro fugidio, um desconhecido perseguido por nós, mas sempre retraído, sempre o próprio velado do ente. Crescemos e nos desenvolvemos assim.

O pensar, desse modo, pode conservar em seu inacabamento justamente essa característica do Real, de não poder absolutizar-se em nenhuma proposição. Heidegger (1927/1997) já havia notado isso nas primeiras linhas de seu livro Ser e tempo, quando fala sobre o ser: "é o conceito mais universal e mais vazio. Como tal resiste a toda tentativa de definição.” (p. 11). O pensar, quando conserva o seu caráter inacabado, é sempre marcado pela presença do Real, que se situa naquele centro fugidio e silencioso que não se deixa capturar e que será sonhado por aqueles que ainda não nasceram. Britton (2003) coloca esse problema na forma da compreensão da alternância entre as posições esquizoparanoide e depressiva (Ep↔D), como parte de um desenvolvimento normal, no qual há uma necessidade de tolerância do estado Ep, como um estado de paciência, para a emergência do ainda não pensado; uma posição emergente de incerteza e incoerência, representada por Ep(n+1). Dissenos Bion (1975/1989), em Uma memória do futuro: "Melanie Klein jamais se reconciliou consigo mesma pelo fato de que, sempre que ela se fazia entender, aquele fato se transformava em algo que ela entendia como não estando mais ‘vivo'.” (p. 98).

O caminho da tempestade, assim, revela-se um caminho peculiar: suas verdades são transitórias, na medida em que conseguem conservar seu inacabamento não sensorial. Tal como o cheiro da terra molhada após a tempestade que se abate sobre o pasto seco, permanecem um pouco no ar e depois se vão. Aquilo que se mantém "vivo" não é mais o conteúdo daquilo que dizemos, mas aquilo que não pode ser comunicado, porque pertence à 
esfera do Real da experiência e, portanto, é passageiro e, paradoxalmente, embora apreensível, não sensorial.

No caminho da tempestade, sentimentos de desastre podem estar presentes quando aquilo que se mantém presente e não comunicado é justamente o Real. Esse Real, desconhecido e negativo da experiência, é a expressão de que o eu mesmo parece ser desconstruído pela emergência desse ponto ausente, no qual surge a alteridade/diferença no ente. O sentimento de desastre do caminho da tempestade é aquela mudança catastrófica que está presente em Édipo, quando pressente que algo ocorreu e que o ocorrido o levará para a destruição do sentimento de mesmidade do eu mesmo. Nesse sentido, o caminho da tempestade, como caminho da análise, parece-se com um percurso cuja trajetória parece ser de ampliação das possibilidades de visitação do Real em seu caráter ontológico, ou seja, com a possibilidade de efetuar uma mudança na personalidade, que a torna marcada pela força disruptiva e transgressora da negatividade, ao consentirmos ser orfandade, desterro, solidão e nada.

A personalidade visitada por essa visitação ontológica não se torna, assim, um desterrado, um solitário, um nada ou um órfão. O consentimento com essa visitação faz com que a personalidade sofra uma mudança catastrófica, que pode torná-la suscetível e aberta justamente à positividade da experiência, de modo que perceba a face humana e a face de uma experiência emocional marcadas pelo desabrigo da quaternidade negativa do Real. A face humana marcada por esse desabrigo (re)descobre o mundo em seu desvelamento como experiência estética, de ser esteticamente, ser obra de arte. A experiência humana, a partir desse desabrigo, pode ser uma revisão da experiência emocional; os fatos clínicos psicanalíticos, assim, parecem ser pura exuberância, em sua transitoriedade e instabilidade. O Real, desse modo, é o espelho escuro que ilumina a exuberância do ente e da palavra; seu reflexo escuro revela a presença do inabarcável e inefável que há em cada manifestação da 
realidade ôntica, em cada palavra do analisando, em cada gesto humano. Essa presença que reflete o negativo nos fatos clínicos psicanalíticos, marcados pela presença do Real, revela cada experiência emocional como abrigo do silêncio sacro do seu centro fugidio. As experiências estão, dessa forma, marcadas por aquilo que são e por tudo aquilo que também não são; somente assim podemos compreendê-las inteiramente. Podemos, também, lembrarnos daqueles versos de Stevens (1950), que nos dizem exatamente isso, mas de um modo tão simples:

It is and it

Is not and, thedfore, is. ${ }^{44}$

\footnotetext{
44 “Isto é, e isto/ não é e, todavia, é." (tradução nossa).
} 


\section{O REAL NOS FATOS CLÍNICOS PSICANALÍTICOS}

O Real nos fatos clínicos psicanalíticos pode ser compreendido por meio de nosso posicionamento: os fatos ocorrem "entre" mundos impossíveis, "entre" registros do impossível. Apenas quando pensamos o sentido desse "entre" mundos, damo-nos conta de que já estamos nele desde sempre e os fatos coligidos no trabalho clínico podem ser vislumbrados como a tensão resultante da relação com o impossível. No entanto, antes de tematizarmos sobre algo que parece ser mais uma espécie de redundância, parece-nos importante destacar que tratamos, com isso, de dar destaque justamente para essa condição fronteiriça de nossa experiência e também daquelas experiências que podemos descrever no trabalho clínico como possuidoras de características que parecem ser, por ora, mais próximas de um ou de outro território; entretanto, pensamos que, embora sejam impossíveis como lugares nos quais a experiência humana sustente-se puramente, são marcas de nossa experiência cotidiana, que flutua entre esses territórios na sua linguagem comum.

Quase não é preciso dizer que Freud (1923/2006r, 1933/2006d) procurou descrever essa condição fronteiriça de nosso psiquismo, tanto quando descreveu o mundo exterior e o reprimido como territórios estrangeiros desconhecidos, quanto ao descrever o psiquismo humano como uma estrutura topológica e o ego marcadamente servindo a três senhores que o bordavam: o id, o superego e a realidade exterior. Ao longo deste capítulo, estaremos desenvolvendo um pensar que procura se organizar a partir desse pressuposto: não habitamos registros do impossível, mas podemos encontrar modos de manter nossa abertura para a sua visitação, para que, por meio disso, não nos afastemos no tamponamento do sentido - seu esquecimento - ou na alienação do vazio e sem formas do Real.

As respostas que matam a curiosidade, como expressão de uma intolerância à incerteza diante do desconhecido, parecem apontar para um desses registros: para a dimensão da tentativa 
de fundamentação de uma organização do pensar que seja simultaneamente luminosa, exuberante e alienante, para tamponar toda e qualquer abertura que possa criar insegurança em face da ausência de formas do Real. Trata-se de um território impossível, à medida que tende a uma alienação sistemática de todo e qualquer registro de abertura para a destituição do sentido; bem como de uma posição defensiva, que cria um mundo que não pode ser colocado em questão. As verdades absolutas desse território são dogmáticas, porque implicam uma tentativa de garantir que possam sobreviver diante de uma ameaça de aniquilamento, que é o pressentimento constante de que a alteridade/diferença anunciar-se-ia como acontecimento inesperado e traumático.

Diante desse problema, há uma tendência a que se organize um modo de se pensar baseado unicamente em $D$, ou seja, incapaz de flutuar entre as posições (Ep↔D), mas em um D cuja linguagem encontra ecos em um belicismo que necessita de objetos malignos contra os quais lutar, objetos que são, na verdade, a intolerância à frustração e sua impossibilidade de lidar com a não coisa no psiquismo, que advém justamente da frustração de preconcepções que são, de fato, irrealizáveis. Esses objetos são, no entanto, as únicas aberturas ao estranho e desconhecido que podem existir nesse território inabitável, embora sejam absolutamente projetados. O território torna-se inabitável porque, em última instância, é um território narcísico, em que se procura manter-se envolvido apenas com aquilo que já se sente ou com aquilo que já se sabe a respeito do eu mesmo.

Podemos encontrar, aqui, uma correspondência com aquilo que foi descrito por Green (1993/2010) sobre a função desobjetalizante da pulsão de morte, como um desinvestimento e, ainda mais, como um modo de desligamento, de desfazer a própria função objetalizante. No entanto, não achamos que essa função desobjetalizante tenha como atividade somente desligar as funções da objetalização, mas conservá-las de tal modo que as torne incapazes de prosseguir sua função, que é criar e proporcionar relações objetais e ligações amorosas; ligações que são, 
na verdade, aberturas para possibilidades. Trata-se, desse modo, do estabelecimento de uma massa de pensamentos estruturados e fixos, que se organiza como uma espécie de arquitetura barroca de paranoias, todas elas entre luz e sombra, opositivas e maniqueístas, em que o sentido, como aquilo que se abre para o "outro quarto", ou para o ponto ausente, mantém-se emudecido e esquecido. Assim, há uma relação também importante com a própria castração, que passa a ser escamoteada para impossibilitar a abertura ao desconhecido. O território é marcado por seu fechamento e tamponamento; os objetos são "duros" e "reais", ou seja, destituídos de alteridade/diferença, marcadamente objetos esquizoides.

Por outro lado, não há como não esquecer a inospitalidade do próprio Real, que se mantém como um território que aparece destituindo os sentidos que haviam sido estabelecidos, por isso mesmo um vazio e sem forma que, ao aparecer, faz-se justamente como um acontecimento disruptivo e heterogêneo. Seu aprisionamento ocorre pela alienação decorrente do estado de pura abertura, no qual não se estabelece sentido provisório, palavra ou expressão, ou seja, não há saturação possível para o psiquismo. Esse "flutuar no vazio infinito e escuro do espaço sem limites" não é tolerado senão como aquele acontecimento que suscita expressão na linguagem e pela linguagem. Quando assim sucede, parece que podemos nos deparar com a escuta daquilo que nos reivindica ser, mas isso já implica uma mudança de posição, que parece pertencer mais às bordas de nossa experiência humana. O Real, como tal, como um território impossível, apenas pode ser identificado com o próprio nada ou com a morte: não é habitável, é registro do impossível, como um vagar a esmo no espaço vazio do infinito, sem fronteiras ou delimitações. Klein (1946/2006) chamou a atenção para isso descrevendo um dos mais primordiais medos humanos como sendo o da fantasia de pairar no vazio do espaço, como angústia de aniquilamento. Winnicott (1957/1982c), por sua vez, trouxe-nos a imagem da queda, do cair, como fonte de angústias e agonias impensáveis. Pensamos que essas duas 
imagens, que tratam do corpo humano envolvido por um espaço vazio sem limites, oferecemnos uma representação desse impossível, desse registro do impossível.

\subsection{Esquecimento e Dissimulação}

Em nosso capítulo anterior, por meio das imagens cambiantes da água, procuramos discutir o problema da abertura ao Real e de como nossas bordas parecem ser tentativas de nos situarmos em face da instabilidade da alteridade/diferença e desse espelho negativo do Real, que reflete imagens escuras nas suas visitações negativas. Ansiamos por aquilo que poderá nos oferecer alguma apreensão de estabilidade, embora seja precário esse apego, criado, no entanto, pela necessidade; estamos à deriva no Real. Pascal (1670/1957), que havia percebido essa dimensão de instabilidade da existência, escreveu em seus Pensamentos:

\footnotetext{
Nadamos num meio-termo vasto, sempre incertos e flutuantes, empurrados de um lado para outro. Qualquer objeto a que pensemos apegar-nos e consolidar-nos, abandona-nos e, se o perseguimos, foge à perseguição. Escorrega-nos entre as mãos numa eterna fuga. Nada se detém por nós. É o estado que nos é natural e, no entanto, nenhum será mais contrário à nossa inclinação. Ardemos de desejo por encontrar uma plataforma firme e uma base última e permanente para sobre ela edificar uma torre que se erga até o infinito; porém, os alicerces ruem e a terra se abre até o abismo. (p. 64).
}

O autor não tratou do problema da tessitura de nossa teia, elaborada como um conjunto de pensamentos oníricos inconscientes - um verdadeiro palimpsesto -, mas observou que nos abrigamos num provisório e instável abrigo iluminado do escuro esquecido da ausência de significações do Real. Nessa bela passagem, há uma compreensão profunda da condição provisória, precária e instável de cada tentativa humana de criar bases e alicerces sólidos; por outro lado, sabemos que em cada possibilidade de elaboração de pensamentos ainda não pensados, de pensamentos que passam a existir por conta de um pensador, em cada novo 
pensar, pode haver uma nova teia, que é lançada no escuro da noite do Real e que também a recobre. Os pensamentos podem se tornar também esquecidos, mas permanecem como fontes de sustentação. Parece, no entanto, que precisamos esquecê-los. Bion (1962/1991b), diferenciando o inconsciente jamais pensado do inconsciente reprimido, não deixou de afirmar algumas vezes que, para que algo se torne inconsciente, é preciso que alguma vez tenha sido tornado consciente e atravesse a barreira de contato composta de elementos alfa. Nesse modelo, o esquecimento parece ser indispensável para a manutenção da abertura ao desconhecido.

Sobre o Real, como o próprio desabrigo, lançam-se tessituras de ilusões, de modo que esse desabrigo é profundamente modificado; parecem ser também as ilusões sintomáticas de um psiquismo falante, que fala por meio de seus sintomas e de seus conflitos sobre a tentativa de dissimular o impacto aterrador da tenaz apreensão do desabrigo e do abismo. McDougall (1991) é de opinião semelhante, quando afirma que os sintomas foram inventados como soluções para uma dor mental insuportável e que há uma poderosa força interna que teme pelo seu desaparecimento.

Como vimos anteriormente, esse abrigo, formado por tessituras de ilusões, inclusive sintomáticas, mantém uma relação de abertura com o próprio Real, mas pode sofrer o viés de ser a sua ocultação ou o lugar conveniente para o seu esquecimento. Em algumas situações, que parecem ser mais claramente encontradas em formas de adoecimento psíquico, o Real parece simplesmente desaparecer e, em seu lugar, sobrevir o emudecimento de objetos que se tornam puramente sensorializados, como palavras jamais esquecidas, e de uma mente que parece estabelecer consigo uma relação puramente sensorial, num esquecimento do "outro quarto". Simultaneamente, o espaço aberto, da atenção livre e flutuante, da disponibilidade para a incerteza, parece adquirir um sentido de perturbação e ameaça que deveria ser dissimulado. Tuan (2005), discutindo sobre o problema dos espaços abertos no imaginário de nossos medos, escreveu: 
Em nenhuma instituição destinada a ajudar crianças mentalmente perturbadas existem grandes espaços abertos, que encorajam movimentos a esmo, vertiginosos, cheios de ansiedade. No Centro Ittleson, o terreno aberto que rodeia o prédio está dividido para promover atividades planejadas. São construídas cercas para definir pequenas áreas, e cada uma tem uma função predeterminada: esta é a área para bicicletas, aquela é uma área de jardim. O espaço interior também é cuidadosamente delineado de acordo com a função e o propósito. Em todos os avisos às crianças em relação a espaço e tempo, a maior ênfase é na clareza da mensagem. As crianças necessitam desenhar círculos fechados, seguros ao seu redor; o círculo aberto, a área sem fronteiras e qualquer espaço com limites ambíguos provocam ansiedade, em vez de um prazer estimulante. (p. 324).

Os círculos fechados, aparentemente mais seguros, podem dar a impressão de que terra, paternidade, coisas e pessoas são objetos determinados que podem ser dominados e postos a serviço de um esforço para diminuir ou esquecer o sentimento de medo e de precariedade, com o objetivo de que, desse sentimento, possa se alcançar um amparo definitivo ou uma plataforma firme, tal como expressou Pascal (1670/1957). Assim, ter um nome próprio e um sobrenome, ter uma casa ou um país, ter coisas ou pessoas e sentir que elas permanecem idênticas a si mesmas parecem estar a serviço de uma tentativa humana de lidar positivamente com a sua abertura ao Real negativo e, eventualmente, com a angústia que essa abertura traz. Entretanto, essa tentativa parece ser uma tentativa que inevitavelmente falha, por ser uma tentativa em que a falha é a própria mola propulsora desse movimento de procura pela resposta e pela certeza, porém nossa falha também nos mostra a impossibilidade de termos linhas demarcadas apenas positivamente, linhas que delineiem as fronteiras da identidade de cada ente, pois a falha revela-nos sermos uma manifestação viva daquela alteridade/diferença que fala em nós, por meio de nós mesmos através do mundo e da palavra. Quando não toleramos falhar, os objetos, que tendem a se tornar mais e mais sensorializados, coisificados, desprovidos de sua face de ícone, de janela ao inefável ou daquele ponto ausente do centro fugidio da experiência, adquirem uma 
substancialidade dura - fechamento - e o homem a eles se agarra e se aferra, como a produção ilusória de uma plataforma firme, na qual encontra sustentação.

Atordoados com a iminência de sua abertura, que nos coloca de modo profundamente instáveis não só com os objetos conhecidos, mas conosco mesmo, tentamos traçar linhas demarcatórias de uma região em que possamos sentir que os anseios por terra, coisas, paternidade e pessoas podem ser realizados de modo a parecerem fronteiras fechadas em tempos de guerra. Trata-se de palavras que se tornam conceitos e devem estar sempre disponíveis para o pensar, sem jamais se ausentarem, sem jamais serem esquecidas. A face da angústia, que se encontra prenunciada no vislumbre desse olhar para além de cada linha do círculo aparentemente fechado, passa a ser temida e designada por pânico, fobia ou algum outro nome de algum outro sintoma. A aparição do desconhecido, o mistério e o desabrigo do estrangeiro heterogêneo tendem a se tornar somente ficções, que servem a propósitos de dominação, de excitação ou de curiosidade, como a do turista que se entretém aos domingos num programa que irá demonstrar que o desconhecido era somente uma categoria anterior ao aparecimento de uma palavra ou de um sentido esquecido que o designaria; portanto, a palavra recobre absolutamente o espaço do esquecimento e da ausência da palavra esquecida. $\mathrm{O}$ desconhecido, assim, parece se tornar um elemento superável, uma vez que haveria algo que o expressaria clara e inteiramente.

$\mathrm{O}$ anseio ardente pela quaternidade positiva transforma os objetos do mundo em ens realissimun, coisas reais, destituídas de alteridade/diferença. Quanto maior parece ser a dor psíquica, parece que mais se torna intensa essa necessidade de criação de objetos reais, ou seja, de coisas desprovidas de abertura e negatividade. Uma nova realidade parece ser assim criada: a realidade dos objetos reais, dos objetos que são o puro reflexo da positividade, que encontra na resposta e no sentido o abrigo radical de esquecimento do Real. Trata-se, no entanto, de um 
emudecimento do mundo, naquilo que fora descrito por Heidegger (1927/1997) como aplainamento das possibilidades do Dasein, na mundanidade do mundo.

[A medianidade] vigia e controla toda e qualquer exceção que venha impor-se. Toda primazia é silenciosamente esmagada. Tudo que é originário se vê, da noite para o dia, nivelado como algo de há muito conhecido. O que se conquista com muita luta, torna-se banal. Todo segredo perde sua força. $\mathrm{O}$ cuidado da medianidade ${ }^{45}$ desentranha também uma tendência essencial do ser-aí, que chamamos de nivelamento de todas as possibilidades de ser. (Heidegger, 1927/1997, p. 180).

Essa passagem de Heidegger (1927/1997) parece indicar um problema central da relação do homem com o mundo humano: no nivelamento das possibilidades de ser, encontramo-nos esmagando aquilo que é pressentido como exceção, como algo de excelência, como aquilo que é fundamental ou originário. Mas a medianidade, por meio da qual existimos na mundanidade do mundo, não é, senão, uma possibilidade de nosso próprio ser. Isso significa que dificilmente toleramos essa abertura jamais inteiramente fechada, que é nossa abertura às condições negativas de nossa existência. A realidade dos objetos reais é simultaneamente o obscurecimento do inefável, o "concerto" da palavra quebrada e o esquecimento do Real. No nivelamento do mundo, encontramo-nos em um universo aparentemente fechado, em um universo em que as coisas aparentemente se transformam em coisas úteis, em coisas para se dispor e em coisas que possuímos e que sabemos qual função têm. Esse universo é a simulação de um universo em que tudo já se encontra pensado ou é pensável e os pensamentos transformam-se em conceitos, que devem se manter sempre disponíveis para um pensar que não é o novo, mas é aquilo que foi armazenado como objeto sensorializado ou como coisa. Como Safra (2004) diz: "Na atualidade, é freqüente ouvirmos de alguns pacientes o relato de um tipo

\footnotetext{
${ }^{45}$ Medianidade é definida como um caráter existencial da impessoalidade do "Ser-Aî". Nessa passagem, o termo 'cuidado' refere-se às realizações ônticas do exercício de existir da "cura". No capítulo 7 de Ser e tempo (Heidegger, 1927/1997), há uma fábula, a Fábula da cura, em que o autor explicita sua ideia da Cura como o "ser" do Dasein.
} 
de sofrimento que é descrito como sofrimento do totalmente pensado.” (p. 66). Um estado de consecutivas significações, que nada mais é do que o próprio tamponamento das possibilidades de um além mais - da pura abertura -, parece ser o movimento desse adoecimento, o qual parece provir da impossibilidade de tornar audível o silêncio sacro do ruidoso impessoal "há": o silêncio do esquecimento do esquecimento do Real, desse mais fundamental esquecimento, uma abertura para a apreensão da realidade psíquica não sensorial.

O nivelamento das possibilidades de ser, do qual nos fala Heidegger (1927/1997), diz respeito a essa forma de adoecimento, que é o fechamento ou o tamponamento da experiência do inefável. No já pensado ou no pensável, parecemos traduzir o mundo humano para palavras que sempre dizem nossa experiência, como se vivêssemos em um mundo em que a tradução poderia ser sempre realizada, de modo a que não fracassássemos na tarefa de interpretar a natureza, mas sabemos do equívoco dessa afirmação. Com isso, pensamos que o Real não poderá ser jamais traduzido. Bion (1965/2004a) já havia notado isso e procurou pensar na diferença entre uma interpretação que traduzisse e uma tradução que encarnasse na pessoa esse mesmo Real. Isso não quer dizer que as sucessivas transformações do Real não possam nos oferecer justamente essa constante abertura ao centro fugidio da experiência ou seu mais além e, com isso, serem alimentos fecundos, oriundos da abertura à verdade que nos alimenta, e, também, tessituras e ilusões, por serem também transformações de um pensamento. Mas as suas transformações, quando estão em remissão e respeito por sua fonte, não podem perder esse mais além do seu centro fugidio, do seu inefável. As significações sem fim podem somente ser uma tentativa desmesurada de procurar alienar esse ponto de fuga, que é um ponto ausente, com a "beleza" de palavras repletas de sentido, mas sem abertura para o seu sem sentido ou para a questão que não é jamais respondida. Como nos disse Pessanha (2000), talvez não precisemos ficar apenas hipnotizados com nossa capacidade de criar belas respostas. 
Freud (1893/2006t), em sua descrição do caso de Elisabeth Von R., que se encontra em Estudos sobre a histeria, mostra-nos como um grupo de ideias eróticas colocou-se no lugar, como resposta, daquilo que poderia ser justamente uma abertura para esse centro fugidio; mas o autor, como sabemos, procurou, como um método de trabalho, manter vivo esse centro ausente e, com a interrogação sempre viva, não se alienava na beleza de uma resposta. $\mathrm{O}$ caso de Elisabeth, entretanto, é uma elucidativa história clínica dessa possibilidade humana de procurar, por meio de um sintoma, alienar-se do desassossego de questões que não conseguem uma resposta puramente tranquilizadora. Nesse caso, os objetivos freudianos, que eram psicoterapêuticos, tinham uma função de tratamento de determinada sintomatologia e procuravam minimizar ou fazer cessar os sintomas da paciente, um conjunto de diversos sintomas que tinham como característica comum a dor. Os sintomas caracterizavam-se pela ocorrência de dores em regiões determinadas de ambas as pernas e em áreas adjacentes; além disso, havia certa dificuldade para a paciente andar e permanecer em pé por conta dessas dores, que posteriormente aumentaram ao ponto de criarem dificuldades para ficar também deitada.

A história clínica da paciente, conforme Freud (1893/2006t) descreve, dá especial ênfase ao caminho de formação desses sintomas, mas torna-se interessante observar que o autor não deixa de descrever alguns traços do caráter de Elisabeth muito peculiares e que poderiam ter sido eventualmente suprimidos, como, por exemplo, o fato de que se tratava de uma "moça orgulhosa", "convencida e insolente", e que ela ocupara o lugar de "um filho para seu pai" (p. 165). Essas caracterizações de sua personalidade talvez tenham servido, na história clínica, para dizer que ela se sentia muito descontente por ser uma mulher, ou por ser frágil, tal como Freud (1893/2006t) diz-nos, sem distinção:

Até então ela se julgara forte o bastante para poder passar sem a ajuda de um homem, mas agora se via dominada pelo sentimento de sua fraqueza como mulher e por um anseio de amor no qual, citando suas próprias palavras, sua natureza congelada começava a derreter-se. (p. 179). 
Mas os motivos desse descontentamento talvez não fossem tão claros. O que significaria ser mulher? Acaso seria o reconhecimento de anseios, buracos, fendas e questões relativas à descoberta de uma "fragilidade"? De algo que parecia ser especialmente feminino? Freud (1893/2006t), no relato desse caso, teve o cuidado de nos oferecer a descrição da vida da família de Elisabeth, que parecia estar, simultaneamente, contribuindo de algum modo, talvez como uma sobredeterminação, ou seja, como a origem de sentidos e motivos inconscientes não necessariamente articulados entre outros sentidos da paciente, para a origem dos seus sintomas. No entanto, nessa descrição, o autor conta-nos que o pai de Elisabeth havia adoecido gravemente e ela havia, por fim, se incumbido da tarefa de cuidar dele; passava dias e noites entregue a essa tarefa, árdua, que fez com que o autor desenvolvesse até mesmo a ideia de que uma das possíveis origens de sua conversão histérica seria esse aspecto "objetivo", relacionado à fadiga proveniente da dedicação e dos cuidados despendidos a esse pai. Durante os 18 meses de cuidados ao seu pai doente, Elisabeth parece ter procurado concentrar-se na tentativa de tratá-lo e de curá-lo, mas essa tentativa acabou por fracassar. Seu pai, passado esse período, faleceu. Os efeitos desse falecimento foram significativos; Freud (1893/2006t) assim os descreve:

A paciente encerrou sua descrição de uma série de episódios com a queixa de que eles lhe haviam tornado doloroso o fato de 'ficar sozinha'. Em outra série de episódios, que abrangiam suas tentativas frustradas de estabelecer uma nova vida para sua família, ela nunca se cansou de repetir que o doloroso nelas tinha sido seu sentimento de desamparo, o sentimento de que não podia 'dar um único passo à frente'. (p. 176).

Esses sentimentos dolorosos intensificaram-se após a doença oftalmológica de sua mãe e, principalmente, após o repentino falecimento de sua irmã. Freud (1893/2006t), em sua descrição clínica, acaba por dar destaque a esse último evento, pois, após árduo trabalho 
psicoterapêutico, encontra um elo inconsciente entre as dores de sua paciente e a voz de um homem que se encontrava, certo dia, na sala ao lado da qual realizavam uma sessão de psicoterapia. Esse homem ao lado era o cunhado de Elisabeth. Ela, ao escutá-lo, pede a Freud para interromper o trabalho terapêutico naquele dia e, junto a esse pedido, aparece novamente a dor da paciente, que estava até aquele momento ausente; aparece de modo repentino e a atormenta novamente, no momento em que deixa a sala em que estava e vai em direção ao viúvo. Por meio desse acontecimento enigmático, Freud ajuda a paciente a desvendar certo pensamento inconsciente, de caráter erótico, que, sendo recalcado, havia-se convertido em dor física. Tratava-se de seu amor pelo cunhado; um pensamento que havia sido recalcado por ela, por ser inconcebível do ponto de vista moral. Assim, por meio de diversas associações, Elisabeth lembra-se, posteriormente, de que no dia da morte de sua irmã, ao se deparar com ela, sua irmã amada, morta, havia-lhe atravessado fortuitamente um pensamento "como um relâmpago nas trevas: 'Agora ele está livre novamente e posso ser sua esposa'." (Freud, 1893/2006t, p. 180).

Esse terrível pensamento, explicativo da conversão histérica, é novamente tratado pelo autor quase três décadas depois. Em A perda da realidade na neurose e na psicose, Freud (1924/2006u) relembra-se dessa passagem e discute novamente esse acontecimento:

De pé ao lado do leito de morte da irmã, ela ficou horrorizada ao ter o pensamento: 'Agora ele está livre e pode casar comigo'. Essa cena foi instantaneamente esquecida e assim o processo de regressão, que conduziu a seus sofrimentos histéricos, foi acionado. Exatamente nesse caso é, ademais, instrutivo aprender ao longo de que via a neurose tentou solucionar o conflito. Ela se afastou do valor da mudança que ocorrera na realidade, reprimindo a exigência instintual que havia surgido - isto é, seu amor pelo cunhado. A reação psicótica teria sido uma rejeição do fato da morte da irmã. (p. 206).

Essa esclarecedora passagem indica que a rejeição (Verleugnen) talvez tenha sido um aspecto esquecido ou não desenvolvido na primeira descrição que ele havia feito do caso. 
Elisabeth havia tido uma reação psicótica em relação à morte da irmã, suprimindo uma parte da realidade, nesse caso, a morte de sua irmã, por conta de uma impossibilidade de abrir mão do impulso inconsciente, do desejo. Nesse momento posterior, Freud (1924/2006u) irá dizer que a neurose da paciente tenta solucionar um conflito que havia sido insolucionável. Como nos diz Simanke (1994): “O ponto crucial da distinção é evidente: enquanto a defesa histérica se dirige a uma moção pulsional inaceitável, o mecanismo psicótico cancela um fato real, com o detalhe de que este fato é tornado insuportável justamente por causa da moção pulsional.” (p. 203). Do ponto de vista do autor, que acompanha o de Freud (1924/2006u), o ato psicótico de Elisabeth estaria no fato de não conseguir abrir mão do desejo, forçando a ter que anular as consequências ou uma parte da realidade.

Pensamos que essa compreensão do ato psicótico de Elisabeth talvez não enfatize que aquilo que era insolucionável e inaceitável talvez não fosse o desejo sexual ou a própria moção pulsional, mas o próprio sentimento de desamparo ou, fundamentalmente, a origem desse sentimento: um encontro com o Real, possivelmente expresso em sua afirmação de que "não poderia dar um único passo à frente" (Freud, 1893/2006t, p. 176). Ele, por sua vez, tornou-se substituído por um grupo de ideias eróticas, as quais parecem ter se posto no lugar justamente daquela experiência negativa da paciente com a própria existência, contemplando dolorosa e desamparada "os alicerces ruírem e a terra se abrir até o abismo" (p. 179). Ou seja, a rejeição não ocorreu pela atitude de cancelar o fato da morte da irmã, mas pela perda ou pela rejeição da radical abertura às visitações do Real, da aterradora experiência de ser visitada pela orfandade e pela solidão, que parece ter sido evocada no falecimento da irmã, já posterior ao falecimento de seu pai. Com a possibilidade de se casar com seu cunhado, Elisabeth não teria que se haver com o fato de que estaria, naquele momento, sendo visitada pela angústia; o estrangeiro inominável ou a face escura revelou-se como pura escuridão e nenhuma luz conseguira iluminar ilusoriamente seus passos nessa escura negatividade. Parece que, ao rejeitar a visita desses 
aspectos negativos, possivelmente representados pelo sentimento de desamparo, procurou fazer com que a neurose tentasse resolver o seu problema, recalcando um afeto que passou a se tornar seu tormento e o ponto a partir do qual sua vida passou a girar, como um ponto de referência, como um eixo, como a partir do qual um peão fica rodando no chão. A angústia, no entanto, diz respeito a um estado de suspensão que nos faz sentir a perda dos significados habituais do mundo, conforme o conhecemos.

Em sua tentativa de criar uma solução erótica para esse problema, Elisabeth impede de ser atravessada pela questão da morte e da angústia, como uma possibilidade de encontro com enigmas e questões insolucionáveis, e essa dor psíquica, relativa à experiência de estar aberta a uma questão inefável, possivelmente não pôde ser experimentada por ela. Elisabeth parece ter se alienado, pela rejeição, desse ponto de fuga, ausente, que era a incerteza em relação ao seu futuro, que era a instabilidade e a precariedade da sua vida e da vida das pessoas queridas, e que era seu anseio por paternidade e por pessoas, que não encontrava mais uma realização satisfatória. Elisabeth parecia manter-se cercada por definições e teorias sobre si mesma, que a faziam se sentir relativamente bem acomodada em um círculo que era anteriormente aparentemente fechado. Na visitação do Real, desencadearam-se enigmas que não puderam ser pensados. Seus sintomas, bem como a origem desses sintomas, parecem ser tentativas de criar as plataformas firmes, respostas bem estruturadas, hipnotizantes em sua função de convencimento; embora pudessem ser, simultaneamente, janelas para a questão.

Os sintomas, nesse ponto de vista, parecem ser pequenas fraturas em que deveria haver apenas a consistência do círculo aparentemente fechado; ou como nos diz Pessanha (2000): "Se o homem-de-Dentro chegou ao divã com uma fobia na pinta escura da nuca, então ele está mostrando que a ruptura começou, que há uma rachadura em sua aparente consistência.” (p. 115). Mas, se por um lado, o sintoma pode ser uma janela para o Real, por outro, o sintoma é justamente um modo de mascará-lo. Como diz Lacan (1964/1985a), que pensava no trauma 
como esse impacto da emergência do Real: "O lugar do real vai do trauma à fantasia - na medida em que a fantasia nunca mais é do que a tela que dissimula algo de absolutamente primeiro, de determinante na função da repetição." (p. 61).

Lacan (1964/1985a) assinala-nos que esse absolutamente primeiro, Real, é dissimulado, mas torna-se determinante para que a repetição do sintoma instale-se. Assim, podemos pensar em sintomas cujo sentido parece ser o de procurar ocultar e dissimular aquilo para o que podem também estar em remissão. Por isso, poderíamos modificar uma famosa máxima de Lacan e dizer: o Real dá aquilo que não tem, embora laboriosamente, como artesãos, produzamos os ornamentos, a beleza, o agalma (Lacan, 1991/1992) que contém essa doação disruptiva, oferecendo o esplendor de uma dissimulação que parece ser a expressão possível do impossível, mas que, na verdade, apenas nos conduz, por meio do desejo, aos caminhos que não vão a parte alguma, que perdem-se, portanto, na infindável rede de atribuições de sentidos possíveis. Isso não quer dizer, no entanto, que o caminho da dissimulação ou do esquecimento não seja trilhado com o propósito de evasão, como tentativa de minimizar a dor psíquica, expressa pela angústia; e, assim, parece ser uma tentativa de alienação do Real. Nessa dissimulação que aliena, há a tentativa de que os sintomas tornem-se partes de uma nova plataforma firme que possa criar, autocraticamente, uma nova realidade, que seja tamponada pelo sintoma, pela força do sintoma dissimulador. Acontece, assim, que, ao olharmos demasiadamente para o sintoma e, desse modo, criarmos com ele uma realidade independente, compactuamos com o paciente na atitude de não permanecer no desabrigo para o qual a experiência ôntica do desamparo remete-nos: na instabilidade perpétua de nossa experiência humana.

Mas a experiência da dor ou da dor psíquica parece ser fundamental para que, por meio dela, encontremos a fenda na positividade da experiência. O sintoma, que é a expressão dessa dor, também procura, com sua manifestação, dissimular essa fenda, atribuindo um sentido para ela; mas essa dor projeta-se para um além do sentido. O sintoma é a manifestação de um padrão 
repetitivo, que dá uma organização psíquica para o que foi apreendido como ausência de organização. Para não desabarmos, para não sucumbirmos ao medo da desintegração psíquica, que a perspectiva do negativo pode trazer, parece que produzimos sintomas dissimuladores. $\mathrm{O}$ psiquismo, assim, parece estar a serviço dessa formação sintomática, que impede o aparecimento do negativo do ser, retomando a existência humana como uma experiência contínua, mas agora contínua a partir do sintoma que se repete, ou seja, repetidamente contínua; em outras palavras, uma continuidade defensiva.

O olhar do analista, já se sabe há muito tempo, deve se dirigir para além do sintoma, mas a atenção que se dirige para além do sintoma pode compreender a dissimulação também como aquela tentativa provisória de que o psiquismo encontre suas razões e seus sentidos repetitivos, enquanto, por outro lado, sente-se impossibilitado de experimentar o centro fugidio da experiência emocional para mantê-lo como silêncio não saturado; um silêncio que não se anuncia como repouso, que não conserva em si mesmo nada mais do que o pressentimento de um esquecimento, que, quando é tornado a presença experimentada de um esquecimento tolerado, pode ser a própria abertura para a irrupção da alteridade/diferença. No sintoma, não encontramos apenas o padrão de uma expressão física que se repete, mas principalmente uma falta de dúvida e uma ausência de abertura em relação ao inefável. De modo geral, já foram circunscritos pelo doente os limites - mesmo provisórios - de sua interrogação, de uma interrogação que está de acordo com a tese de que o sintoma poderia ser substituído por uma resposta, de preferência cheia de inebriante sentido, pois, de algum modo, o sintoma já é, por si só, uma substituição de uma questão ainda não claramente formulada. As perguntas, não raro, são apenas formas de se propor uma resposta, de induzir no interlocutor aquela resposta esperada.

Freud (1909/2006o, 1912/2006i) já havia notado isso e, em inúmeros trabalhos, procurou afirmar a necessidade da abstenção da curiosidade que demanda uma resposta, para 
que o paciente possa formular as próprias questões. Bion (1967/2000a), por sua vez, como mostramos anteriormente, faz da abstenção do desejo e da memória sua única recomendação para o trabalho analítico. Estar com uma resposta cheia de sentido ou indicar com uma pergunta a resposta esperada, no entanto, é fazer um esforço absolutamente oposto, em completa oposição à origem do sintoma, um esforço pelo esquecimento, pois esse esquecimento parece acontecer na exuberância das preposições repletas de sentido, as quais são respostas ferozes à apreensão assustadora da ausência de formas, de sentido ou de respostas; enfim, algo que pode ser pressentido como possivelmente traumático e catastrófico.

Bion (1965/2004a) cita Eckhart ao dizer que o pensador considerava que a Divindade era trevas e ausência de formas, contendo, no entanto, todas as qualidades ainda não desenvolvidas, pois, como havíamos discutido anteriormente, enquanto o trauma assinala a ocorrência de um acontecimento inesperado e incontrolável, a catástrofe anuncia a dissolução de uma experiência de continuidade. Ambos, no entanto, assinalam que esse acontecimento desancora também em decorrência da permanência inexorável da alteridade/diferença intrusiva, ou como parte do eu mesmo ou como um estrangeiro indesejado que não se consegue pôr para fora, e que se irá, retrospectivamente, tentar atribuir sentido e coerência para esse acontecimento. Trata-se, assim, da permanência de algo também não desenvolvido ou transformado pela mente, algo que permanece em estado "bruto", sem formas, portanto, sem transformação.

A dissimulação que está presente no sintoma parece advir do fato de ele parecer possuir uma resposta simultaneamente enigmática e hipnotizante. Como resposta hipnotizante, ele se aproxima daquela sedução que se esforça por ser tão explícita, tão descarada, que remete nossa atenção apenas para ela mesma, apenas para a sua presença, e faz com que percamos a dimensão de profundidade ou de perspectiva. Colamo-nos, no sintoma, em sua superfície lisa e 
sem buracos. Como dissimulação enigmática, ele ainda pode conservar alguma relação com o esquecimento, no sentido que nos dá Blanchot (2007):

Quando sentimos falta de uma palavra esquecida, ela se designa ainda por essa falta; nós a temos por esquecida e assim a reafirmamos nessa ausência que ela parecia ter sido feita unicamente para preencher e dissimular-lhe o lugar. Na palavra esquecida, apoderamo-nos do espaço a partir do qual ela fala e que agora nos remete a seu sentido mudo, indisponível, interditado e sempre latente. (p. 171-172).

Nessa dissimulação enigmática do sintoma, há um esquecimento que se conserva, mesmo na repetição, como essa ausência da palavra. Podemos observá-lo quando não preenchemos essa ausência com alguma palavra ou resposta que ocupe esse lugar rapidamente, que é um desterro para a palavra. Que grande respeito pela verdade encontra-se na possibilidade do esquecimento das respostas, na tolerância desse espaço vago que apenas poderia ser preenchido com algo que não estará jamais presente, apenas em um sentido mudo e indisponível! Por outro lado, o acontecimento do sintoma não se dá justamente no esquecimento dessa verdade, que corresponderia a uma afirmação final de "sentidos verdadeiros"? Pois o sintoma ocorre nesse espaço do qual ele fala, espaço em que as palavras ditas são atravessadas por uma nudez, ausência e retração, e são, assim, palavras quebradas; ou seja, o sintoma, que é dissimulador e enigmático, conserva esse espaço mudo, ainda não saturado, que parece abrigar justamente a possibilidade de inúmeros acontecimentos. Seu sentido mudo, ausente, indisponível, interditado e sempre latente parece ser a própria falta de sentido que ele tem ou seu aspecto de pura abertura e de negatividade. $\mathrm{O}$ sintoma parece ser a palavra que deveria preencher e dissimular o lugar de sua ausência e, assim, negar o negativo, afirmando-o como uma palavra recordada, que é pronunciada como a manifestação da certeza da expressão.

O sintoma dissimulador é enigmático e hipnotizante, e pretende dar uma resposta, mas erra em seu intento por ainda resguardar a mudez de uma palavra esquecida, de uma palavra que 
sabemos, no entanto, ser inexata para acabar completamente com essa mudez ou imprópria para ocupar inteiramente esse lugar aparentemente destinado exclusivamente a ela. Enquanto se esforça por dizer explicitamente seu sentido, resguarda um enigma que é o guardião dessa ausência, um contínuo buraco em que se abriga tanto a própria palavra muda quanto a possibilidade da existência das coisas que estão indisponíveis, mas é nessa possibilidade, nesse verdadeiro buraco para o sentido, que é criada uma travessia, a travessia palimpséstica humana. Os sintomas, desse ponto de vista, parecem formas de dissimulação quando hipnotizam aquele que faz a travessia, de modo a fazer com que aquele que atravessa não olhe nunca para baixo, para não sucumbir pela vertigem e pelo medo de cair, um dos mais primordiais medos humanos. Winnicott (1957/1982c) referiu-se a esse medo diversas vezes e deu ênfase à importância do holding, tendo em vista, simultaneamente, a queda.

A frase de Elisabeth, de que não podia "dar um único passo à frente" (Freud, 1893/2006t, p. 176), pode agora ser revista e parece se tornar um mote incrivelmente expressivo desse homem que faz a travessia; de quem faz a travessia e, em algum momento, no meio dela, somatiza. Também não podemos nos esquecer de que Freud (1900/2006b), algum tempo depois, parece ter sonhado justamente com isso, com essa travessia, no seu Sonho da sepultura etrusca. ${ }^{46}$ Parece conservar, nesse sonho, a pureza de um enigma sobre a travessia, que parece

\footnotetext{
${ }^{46}$ O Sonho da sepultura etrusca, de Freud (1900/2006b), é contado dessa forma na Interpretação dos sonhos: "O velho Brücke devia ter-me atribuído alguma tarefa; ESTRANHAMENTE, relacionava-se com a dissecação da parte inferior de meu próprio corpo, minha pélvis e minhas pernas, que eu via diante de mim como se estivesse na sala de dissecação, mas sem notar sua ausência em mim mesmo e também sem nenhum traço de qualquer sentimento de horror. Louise N. estava de pé ao meu lado e fazendo o trabalho comigo. A pélvia tinha sido eviscerada e era visível ora em seu aspecto superior, ora no inferior, estando os dois misturados. Podiam-se ver as espessas protuberâncias cor de carne (que, no próprio sonho, fizeram-me pensar em hemorróidas). Algo que estava em cima disso e que teve de ser cuidadosamente retirado. Depois eu estava novamente de posse de minhas pernas andando pela cidade. Mas (por estar cansado) apanhei um táxi. Para meu espanto, o táxi entrou pela porta de uma casa, que se abriu e deixou passar por um corredor que dobrava uma esquina no final e, por fim, levava de novo ao ar livre. Finalmente, eu estava excursionando numa paisagem mutável, com um guia alpino que carregava meus pertences. Parte do caminho ele me carregou também, por consideração por minhas pernas cansadas. O terreno era pantanoso e andávamos pela beirada; havia pessoas sentadas no chão como peles vermelhas ou ciganos - entre elas uma moça. Antes disso, eu estivera avançando sobre o terreno escorregadio com uma constante sensação de surpresa por poder fazê-lo tão bem após a dissecação. Por fim chegamos a uma casinha de madeira em cuja extremidade havia uma janela aberta. Lá o guia me colocou no chão e pôs duas tábuas de madeira, que já estavam preparadas sobre o peitoril da janela, de modo a fazer uma ponte sobre o abismo que tinha de ser cruzado a partir da janela. Nesse ponto fiquei realmente amedrontado por causa das minhas pernas, mas, em vez da esperada travessia,
} 
ter sido encontrado ainda como palavra esquecida nesses atendimentos de Elisabeth e que resguarda a mudez, a interrogação sem resposta e aquela situação em que a palavra falta; ou como nos diz Ab'Saber (2005):

O sonho de Freud, agora, é também o sonho pessoal que reverte o risco do negativo do ser, a ruptura na continuidade da experiência da vida, dada no próprio dormir como possível experiência de radical não integração psíquica, em um ato psíquico fundante, ato de elevação simbólica definitiva e definição de padrões próprios de um ser, em seu desejo e nas formas de um sonho: quem correu o risco de morrer no próprio sono, de desabar no campo do irrepresentável negativo, angústia impensável, foi o próprio Freud, o sonhador da reversão da própria morte, e que se descobre, desde os poderes do sonhar, o sujeito humano, extasiado nas formas de sua pesquisa humana singular, em sua arqueologia profunda da alma, sua psicanálise. (p. 256).

Nessa bela passagem, o autor mostra como o sonhar pode acontecer a partir desse risco fundamental, de sucumbirmos à experiência com o Real. Os poderes do sonhar, assim, são como fundações de experiências positivas atravessadas por esse risco tão básico, tão originário, mas a possibilidade de sonhar esse tipo de sonho, torná-lo uma dimensão psíquica, torná-lo um sonho que traz esse risco, o risco dessa travessia, possivelmente deu a Freud (1900/2006b) possibilidades de atravessar diversos dos abismos que encontrou: abismos da alteridade/diferença, do palimpsesto humano; abismos da apreensão da pergunta que não se esgota em qualquer resposta; abismos da negatividade da experiência inefável; abismos entre o Real e a realidade; e abismos profundos de nossa incognoscibilidade jamais ultrapassada. Parecem ser todos riscos do negativo, riscos que nos são absolutamente inerentes, mas que apenas vez ou outra podem ser realmente sonhados e, assim, com eles, o homem deixa-se ser visitado. Nesse profundo e significativo sonho, podemos ainda vislumbrar que há um abismo duas crianças dormindo ao lado deles. Era como se o que iria possibilitar a travessia não fossem as tábuas, mas as crianças. Acordei sobressaltado.” (p. 484-485). O sonho tem esse nome pelo fato de que, após ele, Freud associou-o da seguinte forma: "O sonho parece ter dito: se tens de descansar numa sepultura, que seja uma sepultura Etrusca." (p. 487). 
que se apresenta como inabitável e também como impossível de ser, naquele momento, ultrapassado por ele. Rudge (citada por Ab'Saber, 2005) tratou desse assunto na seguinte passagem:

Em 1927, o autor retoma um sonho seu, que analisara em 1900, e o interpreta como uma forma de lidar com o desamparo através de uma fantasia de realização de desejo. Considera que o sonho foi causado pelo cansaço e por uma sensação de fraqueza que sentira durante o dia, e que lhe evocaram o seu envelhecimento, trazendo o angustiante pressentimento de que o momento de sua morte não estava longe. A elaboração onírica se encarrega de transformar esse pressentimento angustiante em uma cena de realização de desejo, na qual Freud se encontra em um túmulo etrusco, que visitara em Orviedo, feliz por satisfazer seu interesse na arqueologia. Apesar do sucesso do trabalho onírico em transformar o pensamento que convocava a ameaça de desamparo em uma realização de desejo, Freud acordou tomado pela angústia. [...] O desejo encobre e sinaliza um fato, um significante vindo do real, que desconcerta, que ameaça, e que entretanto insiste, exigindo trabalho. A causa do sonho não é mais, portanto, o desejo. Este é o instrumento com que se busca dar conta do desamparo em que algum fato recente precipitou o sonhador, para recolocar o princípio do prazer em funcionamento. (p. 257).

Nessa rica passagem, somos convidados a pensar nessa intrigante relação existente entre o princípio do prazer-desprazer e o desamparo. A ameaça de desamparo, incluída no acordar do sonho, ofereceu um novo vértice para a apreensão do sentido do sonho, agora caracterizado como um modo de encobrir e, ao mesmo tempo, sinalizar algo da ordem do Real, que surge difusamente com sua participação na organização do psiquismo pelo princípio do prazerdesprazer. Trata-se, fundamentalmente, de um abismo intransponível. No entanto, podemos dizer que, ao nos legar esse mesmo sonho, essa impossibilidade de realizar naquele instante a travessia, uma travessia possivelmente endereçada a um vislumbre da própria morte ou de um pensamento sobre a morte e o desamparo - que, como sabemos, Freud iria a partir de 1920 se dedicar incansavelmente -, e escrevê-lo para aqueles que seriam seus futuros leitores, Freud (1900/2006b) também nos legou a tarefa de sermos aqueles sonhadores que sonhariam 
novamente esse sonho, para que, assim, pudéssemos pensar aquilo que haveria ainda para ser pensado. O Sonho da sepultura etrusca parece ser, desse modo, um convite para que sonhemos o que Freud não pode sonhar. Ainda, como nos diz Ab’Saber (2005):

\begin{abstract}
A história da psicanálise tem prosseguido o sonho freudiano e pôde avançar, de forma a fundar novamente o campo, exatamente ali onde as pernas cansadas do mestre tiveram que parar. Temos, nós mesmos, psicanalistas posteriores, continuado o sonho freudiano, na medida em que podemos compreendê-lo e integrá-lo em nós, e reconhecer seus limites que nos sejam mais nítidos, bem como nossa própria possibilidade para ajudar Freud a prosseguir em seu próprio sonhar. (p. 306).
\end{abstract}

Ainda na Interpretação dos sonhos, Freud (1900/2006b, p. 580) diz-nos que o sonho pode transformar o "mais indesejado de todos os pensamentos" ou "a mais lúgubre das expectativas" em um pensamento desejável, em uma realização de desejo. Portanto, o autor encontra, no sonho, essa clara função de fazer com que algo absolutamente funesto possa converter-se em algo desejável e, assim, ser pensado e transformado pelo pensar em formas de sonho. Em seu sonho, o sonhador recorda-se daquilo que se mantém como dúvida, como recordação incerta de uma palavra esquecida. O Sonho da sepultura etrusca parece ser, assim, o sonho que Elisabeth não pôde sonhar, mas não pôde sonhar porque, simultaneamente, não pôde se esquecer; esquecer dos sentidos e das respostas que impedem a ausência da palavra. Como dar um passo à frente quando o que vislumbramos é apenas o nadificante e gélido escuro de um buraco desconhecido e irrepresentável? Pois o passo à frente pareceria ser possível apenas se caminhássemos a esmo, quando se caminha sem se preocupar com a cegueira da travessia, no caminho de uma travessia às cegas; quando não se enxerga nada do que acontece consigo mesmo enquanto se caminha e, assim, nada se sabe da precariedade do caminhar.

Os sintomas parecem dissimular e hipnotizar na medida em que a travessia é visitada como irrupção do Real. Nessa dissimulação, há uma tentativa de que a atenção disperse-se, que 
a mente produza suas razões, seus sentidos e concentre-se justamente naquilo que afastará seu olhar da vertigem de uma visão assustadora. Enquanto isso, continuamos inevitavelmente a travessia, ou jogando novas teias por sobre a noite escura, como tecelões de frágeis fios, como aranhas cerzindo sua frágil teia, ou apenas seguindo aqueles velhos fios, andando repetidamente pelos caminhos do pensamento já traçado. Portanto, se o sintoma é um modo de esquecimento do Real, por outro lado, é necessário que possamos esquecer esse esquecimento, pois só assim encontraremos o espaço da ausência que permite com que vislumbremos que as palavras, sintomas, sentidos ou respostas jamais encontram a sua morada definitiva nesse espaço para o aparecimento do sentido; são apenas transitórios e perecíveis. No entanto, parece-nos que abrigar esse aspecto transitório e perecível da palavra torna o interlocutor silencioso para poder dizer aquilo que quer ser dito, ou melhor, a palavra é silenciada para que possa ser dita como se fosse dita pela primeira vez, inaugurada como aquela palavra estranha que surge de longe, incerta e instável, e que anuncia um dizer que é, naquele momento, indizível e único. Esse dizer é o fato que se torna poema. No poema, resguarda-se aquilo que não está jamais disponível e que pode ser assinalado pelas palavras que renunciam explicação.

Bion (1970/1991a), em A atenção e interpretação, no início do capítulo final do livro, faz uma citação de uma carta de Jonh Keats a George e Thomas Keats, de 21 de dezembro de 1817. Nessa citação, encontra uma expressão do poeta que usaria com certa assiduidade: a capacidade negativa. Eis a citação:

Não discordei de Dilke, mas discorremos sobre assuntos vários: temas combinam-se em minha mente e, aí, me ocorre a qualidade que plasma o Homem que Alcança, mormente em Literatura, e Shakespeare revela-o de modo muito amplo, ou seja, a Capacitação Negativa, isto é, o homem que tolera incertezas, mistérios, dúvidas, sem a busca desesperada pelo fato e motivo. (Keats, citado por Bion, 1970/1991a, p. 136). 
Essa citação indica que tolerar incerteza, dúvida, mistério etc. parece ser oriundo de uma capacidade, a qual Keats denomina negativa. Essa capacidade é uma capacidade negativa porque diz respeito a um estado de mente em que se é possível realizar uma negação completa daquilo que ordinariamente se denomina realidade. Citamos Bion (1970/1991a):

Freud, em carta a Lou Andreas-Salomé, sugere-lhe seu método de atingir o estado mental que na escuridão divisa objeto apenas obscuro. Afirma cegar-se artificialmente. Como método para conseguir cegar-se de maneira artificial, advogo a importância de rechaçar memória e desejo. Em adição ao método e ampliando-o, incluo entre as condições a compreensão e a percepção sensível. Abster-se de memória, desejo, compreensão e impressões sensíveis parece impossível sem a negação completa da realidade; o psicanalista busca algo diferente do que, de ordinário, se conhece como realidade; desconsiderar o que em geral se entende por realidade não implica inconveniência para o propósito de alcançar o contato com a realidade psíquica, isto é, as manifestações que evolvem de O. (p. 53-54).

Essa capacidade negativa, portanto, parece ser oriunda de uma possibilidade de abstenção, na qual há uma negação da realidade tal como ela é conhecida. No entanto, ainda como método, é preciso acompanhar a evolução de um desconhecido e o foco permanecer nesse desconhecido, que poderá ser um contato com a realidade psíquica que designamos como palimpséstica. Na escuridão da capacidade negativa, podem-se tolerar dúvidas e incertezas, porque aquilo para o que se mira não é nada de conhecido, não é algo que se procure designar como uma preposição definitiva. O contato com a realidade mental é o próprio contato com aquilo que é absolutamente distinto do que se pode apregoar como sendo real, como um sintoma muito frequentemente faz: designar-se como coisa real, como um objeto conhecido e, como vimos, dissimulador.

Nessa situação enigmática, pode-se constituir uma interlocução analítica em que dois interlocutores estão ambos num movimento comum, que é o de confrontarem-se radicalmente com aquilo que ambos desconhecem. Estão ambos cegos para o emergente dessa situação e 
procuram manter-se, tanto quanto possível, em uma escuridão, na qual é negado sucessivamente aquilo que já se sabe da realidade proveniente da memória e do desejo de ambos. Procura-se, desse modo, enfrentar o risco dessa situação, uma situação tão arriscada a ponto de fazer com que ambos possam permanecer preparados para criar autocraticamente qualquer realidade que seja um porto seguro, para que se configure uma narrativa naquele lugar em que não há narrativa, em que há apenas o atroz medo de sucumbir na escuridão, no buraco aparentemente vazio e nadificante do Real, que suscita a própria catástrofe.

A interlocução não é um diálogo sobre o mesmo, não é um diálogo em que se procure acolher a compreensão daquilo que já foi dito. Torna-se uma situação estranha e de profunda indisposição: o estranho que deve aparecer pode ser apenas uma fagulha daquele estranhamento não revelado que ronda pelo ar, que ronda inabarcável em sua totalidade e que não se deixa ser pensado por inteiro; ele é a negatividade pura, do desabrigo do Real, que obscuramente nos convoca a situarmo-nos conforme uma perspectiva de alteridade, em que os pontos de vista são constantemente suplantados, em que uma visão binocular é exigida como condição para que os paradoxos, as contradições, as desigualdades e os conflitos sejam apreendidos não como uma tentativa de superação, mas como uma forma de apreensão dessa alteridade/diferença radical, que está sempre presente na interlocução como um ausente sempre presente, que se encontra além de cada palavra e também dentro de cada oração.

Nessa interlocução analítica, o estrangeiro, que é a própria alteridade, vai se tornando, aos poucos, cada qual dos interlocutores, que nesse diálogo desigual podem fazer eclodir, como eclode um botão de flor, a natureza estranha e estrangeira de cada preposição que surge como uma abertura ao Real desconhecido. Nesse movimento dialógico, os interlocutores podem sentir a presença daquela alteridade que ocorre neles mesmos, quando se implicam com a presença da diferença que se revela naquilo que se diz, quando, simultaneamente, há a possibilidade de esse mesmo dizer ser esquecido e suplantado constantemente, quando há a possibilidade estranha de 
desapego sobre a origem do pensamento, porque não podemos dizer que, nesse tipo de interlocução, uma verdade foi pronunciada por um dos “eus”, mas que não se configuram mais “eus” e sim aberturas dispostas à escuta da diferença/alteridade que se faz presença no pensar. O interlocutor torna-se, desse modo, o estrangeiro, o outro, a própria diferença/alteridade, sem que o hiato entre conhecer e ser permaneça como um hiato. A fala analítica é uma ocorrência que disponibiliza não somente uma mudança no analisando, mas uma mudança vertiginosa nos interlocutores, porque permite ser a abertura para a visitação do Real, em que convoca ambos para a experiência do desabrigo radical da verdade que despersonaliza cada interlocutor, em que se sucedem o acontecimento da instabilidade de cada verdade e a reivindicação desse Real, ou seja, ser a partir do nada, do desterro, da solidão e da orfandade.

A capacidade negativa parece ocorrer quando se torna possível ser a partir da quaternidade negativa do Real, mas trata-se de uma disponibilidade para que se seja, por meio dessa quaternidade, por meio da tolerância a esse desabrigo, a tessitura de pensamentos não pensados, que surgem desse obscuro escuro sem formas, que não é nada, que é o próprio Real e, simultaneamente o "nascente mundo de profundas, obscuras águas" de que nos fala John Milton (citado por Bion, 1965/2004a, p. 176). Isso significa somente que não há como poder ser pensada uma negatividade que não seja, ainda assim, uma positividade, ou seja, na quaternidade positiva, já encontramos a abertura da negatividade, as janelas icônicas do Real, e, na negatividade, encontramos, também, expressões do ser, por meio de suas demandas ou necessidades ou, simplesmente, pela atenção da alteridade/diferença, na abertura ao desconhecido que se encontra no "quarto ao lado", respeitado e tolerado como fonte de uma situação triangular, de um existente, de um "há" que demanda tornar-se existência e que não precisa ser tamponado com a criação de imaginações que encubram, pela intolerância, o ponto ausente observado fundamentalmente na cena primária. 
Na interlocução analítica - uma fala absolutamente incomum -, ambos os interlocutores, quando se tornam perseguidores desse manancial do "nascente mundo de profundas e obscuras águas", perseguidores que não são exatamente perseguidores, pois não estão envolvidos exatamente pelo desejo, mas por um movimento de abertura próprio de uma interrogação do desconhecido, porém não aquela que já pressupõe uma resposta, pois o que se pergunta não é um enunciado que almeje um conteúdo exato, mas apenas uma interrogação sobre a apreensão do estado mental que se desenvolve em uma sessão; quando podem se tornar envolvidos nesse propósito absolutamente obscuro, estão, simultaneamente, endereçados a algo que é um terceiro elemento, que já foi anteriormente concebido, como possibilidade, pela dupla. Esse terceiro elemento, desconhecido, é a própria alteridade/diferença que jamais pode ser alcançada pelo conhecimento; ela é um "terceiro analítico", para usar a famosa expressão de Ogden (1996a).

A presença assustadora desse elemento triangular apenas pode ser pacificada quando se imagina que poderá ser encarnado e, assim, possa ser diminuída a intensidade de sua presença disruptiva e sempre excedente. Seu excesso, seu caráter disruptivo e sua permanente presença inabarcável sobre o psiquismo também nos convidam a testemunhar a impossibilidade de que essa encarnação possa ser uma realização plena; assim, permanecemos sempre indisponíveis para abarcar sua totalidade, ou seja, toda a orfandade, todo o desterro, toda a solidão e todo o nada que querem se tornar um ato positivo de ser na situação analítica. O pensamento não pensável do Real é, portanto, um elemento que transcende toda pessoalidade, toda forma de dicção e expressão de uma singularidade, embora ocorra sempre em determinada pessoa. Ele não é um pensamento que se possa possuir, como um conhecimento; não é um pensamento que se possa ter, a não ser pela possibilidade de se tornar esse próprio pensamento, ou melhor, de sêlo, mas ir sendo esse pensamento ou esse Real é também apreender o seu excedente, o seu inabarcável, a sua impossibilidade de realização completa. O pensamento não pensado do Real é, desse modo, ir sendo o ato negativo da quaternidade negativa enquanto paternidade, coisas, 
pessoas e terra são consecutivamente realizados e se afastam de nós como anseios irrealizáveis. Sabemos, assim, que tanto a quaternidade negativa quanto a quaternidade positiva são, essencialmente, impossíveis, no sentido de que não são jamais experiências ônticas e que, como dimensões ontológicas, são impossíveis em sua totalidade. Não só a orfandade, por exemplo, é impossível, como a própria paternidade também não se realiza inteiramente, mesmo na companhia de um pai.

Julgamos essenciais certos aspectos de nossa personalidade. Achamos que, sem termos certos aspectos, como a pessoalidade do eu mesmo, poderemos sucumbir à doença mental. Esse antigo medo retira-nos da face sombria do Real, mas poderia nos recolocar a experiência de ser em um novo âmbito, pois sermos, nessa destituição do eu mesmo, significa nos devotarmos profundamente ao cuidado - e essa é a verdadeira ética do trabalho analítico, que é uma ética não só do cuidado pessoal, mas uma ética que, ao despersonalizar, evidencia-nos nossa condição humana, de navegantes aparentemente sem rumo, sem deus, em um universo escuro e frio, que não reflete a nossa face senão banhada em escuridão - e sermos, portanto, tão próximos, fraternalmente, de cada alteridade/diferença existente em cada expressão de nosso $e u$ mesmo, agora tornado universalizado, em sua destituição subjetiva.

Talvez devêssemos pensar, portanto, e paradoxalmente, que, de um ponto de vista ético, devemos estar sempre atentos de que, em cada palavra ou sintoma, já há um esquecimento do Real e que, por isso, é necessário que possamos, como início de trabalho, lembrar-nos de que há esse esquecimento. Embora essa lembrança não possa se figurar como parte do processo de investigação, do próprio método psicanalítico, que pressupõe um necessário esquecimento para que possa sobrevir o sentido ainda não pensado ou o sentido esquecido, a lembrança de que há um processo de esquecimento parece ser aquele ponto de partida ético a partir do qual o processo psicanalítico pode se desenvolver. Assim, parece que a lembrança do esquecimento e 
o esquecimento do esquecimento devem estar em sucessão, de modo que o método possa ser, inclusive, antecedido por uma ética.

E a psicanálise pode tecer sobre o abismo tessituras éticas frágeis e esburacadas. O fato clínico psicanalítico, assunto que nos convida a longas reflexões, parece que pode, neste momento, ser novamente considerado, pois os fatos, tais como podemos apreender, não podem ser caracterizados como fatos, nos sentidos que usualmente se atribuem a isso, como, por exemplo: $\left(1^{\circ}\right)$ de ação realizada; $\left(2^{\circ}\right)$ de um feito; ou $\left(3^{\circ}\right)$ daquilo que é real, do fenômeno ou de uma verdade (Houaiss, 2009). Em qualquer uma dessas definições habituais, encontramos uma tentativa inamistosa de divisão não explícita entre algo real e algo irreal, e de compreender um fato como um acontecimento observável pelos sentidos, portanto, real. A palavra 'fenômeno' parece acentuar e aprofundar essa definição, como aquilo que se apresenta já modificado e alterado pelas condições do próprio observador, incluindo aqui, possivelmente, as condições da lógica assimétrica do próprio pensar, do modo como discutimos anteriormente, no primeiro capítulo deste trabalho. Os fatos seriam, nessa lógica, a realidade que se apresenta observável pelos sentidos e que já é uma modificação realizada pelo pensar.

Poderemos, agora, retomar uma pergunta que foi realizada em determinado momento de nosso trabalho: a de que o problema que havíamos nos proposto era compreender se os fatos clínicos psicanalíticos seriam o esquecimento ou a visitação do Real. Mas essa pergunta, neste momento, pode ser compreendida de modo absolutamente diverso, pois, se por um lado observamos que os fatos clínicos não podem ser compreendidos a não ser como fatos que guardam em seu bojo toda a dimensão ontológica da experiência com o Real, ou seja, que, nos fatos clínicos psicanalíticos, há a ocorrência do Real, mesmo que a dissimulação e o esquecimento, como fenômenos inebriantes, capturem nossa atenção, por outro, eles parecem abrigar a ocorrência de uma permanente abertura ao desconhecido, muito embora possam ser, inversamente, uma tentativa de fechamento à alteridade/diferença, que jamais se torna 
absolutamente fechada, portanto permanentemente ameaçada por visitações. Por isso, os fatos não podem ser compreendidos como expressões de uma visitação ou de um esquecimento do Real e isso se deve ao fato de que, em cada fato clínico psicanalítico, em cada ocorrência da sessão de ações, feitos, palavras, gestos, silêncios ou atos, tanto do paciente quanto do analista, podemos apreender certa ocorrência do Real e, simultaneamente, modos de seu esquecimento. Os fatos clínicos psicanalíticos são embebidos pelo Real, muito embora não possam permanecer como uma expressão ontológica do Real inteira e totalizante em um movimento ôntico.

Há, no ôntico, no fato clínico, em cada palavra proferida, em cada gesto, ato, interpretação ou silêncio, uma inexpressividade jamais suplantada e um abismo de desconhecimento e de negatividade. As tessituras éticas psicanalíticas, frágeis e esburacadas, são aqueles fatos clínicos desenvolvidos e transformados nas sessões, por meio de seu método, que podem garantir, com sua fragilidade, que sejam lançadas novas teias por sobre o abismo, que se mantenham sempre instáveis e possam ajudar-nos a sentir a presença excessiva e monumental do Real, que não é jamais tornado teia, palavra ou fato clínico. A ética desse movimento reside na tentativa de não alienar a dupla de sua participação mútua na verdade do aspecto transitório do pensar e da existência humana, instável e incerta. A lembrança do esquecimento do Real parece surgir, assim, naqueles momentos em que se atinge uma verdade e se deseja, por algum motivo, torná-la aquela plataforma firme, tenaz e definitiva. Nessa hora, a lembrança do esquecimento pode nos nortear novamente, ajudando-nos a recobrar as forças provenientes dessa mesma ética, que acolhe essa dimensão de desconhecimento e de instabilidade como marca absolutamente humana, de todos nós.

\subsection{Visitação do Real}


Retomemos, agora, um aspecto de nossa exposição que parece ter permanecido nebuloso. Afirmamos anteriormente que o método clínico psicanalítico é um modo de tornar possível esquecer o esquecimento do Real, de modo a fazer com que o espaço da ausência decorrente desse esquecimento torne-se uma abertura que revele a incapacidade da palavra de se tornar o tamponamento completo desse espaço que não é somente destinado a ela. As palavras, portanto, são desajustadas a esse espaço; transitórias, desproporcionais e errantes, surgidas com esse espaço de sua ausência e banhadas por ele, parecem ser sempre incertas e pouco precisas, e, no entanto, são simultaneamente uma aparição repleta de estranhamento daquele "nascente mundo de profundas, obscuras águas", de que nos fala John Milton (citado por Bion, 1965/2004a, p. 176). Essas palavras podem ser expressões do desvelamento de experiências emocionais inefáveis de estranho desassossego, que expressam o acontecimento da alteridade/diferença.

Heidegger (1938/1998) descreve essa experiência como uma disposição de ser um “estranho dentro do ente" (p. 78), se bem que poderíamos descrevê-la como um ente dentro do estranho. Já Hölderlin (1800/1991), em seu poema Quando era menino... ${ }^{47}$, parece trazer justamente essa questão da presença de palavras que surgem desse espaço de ausência, de palavras que, ao ocupá-lo, parecem se tornar expressões de um desconhecimento ao nomearem a familiaridade das coisas. O poeta parece descrever, com esse sentimento de ser "estranho dentro do ente", justamente seu modo de esquecimento do esquecimento do Real. Eis o poema:

\section{Quando era menino}

\footnotetext{
${ }^{47}$ O poema de Hölderlin (1800/1991) é intitulado Da ich ein knabe war... e foi escrito entre 1796 e 1798 , na época de Francoforte-do-Meno. Ele diz: "Da ich ein Knabe war,/ Rettet ein Gott mich oft/Vom Geschrei und der Rute der Menschen,/ Da spielt ich sicher und gut/ MIT den Blumen dês Hains,/ Und die Lüftchen des Himmels/Spielten mit mir./ / Und wie du das Herz/ Der Pflanzen erfreust,/ Wenn sie engegen dir/ Die zarten Arme stricken,/ So hast du mein Hertz erfreut,/ Vater Helios! Und, wie Endymion,/ War ich dein Liebling,/ Heilige Luna!/ / O all ihr treuen/ Freundlichen Götter!/ Dass ihr wüsstet,/ Wie euch meine Seele geliebt!//Zwar damals rief ich noch nicht/ Euch mit Namen, auch ihr/ Nanntet mich nie, wie die Menschen sich nennen,/ Als kennten sie sich./ Doch kannt ich euch besser,/ Als ich je die Stille des Aethers,/ Der Menschen Worte verstand ich nie.// Mich erzog der Wohllaut/ Des säuselnden Hains/ Und lieben lernt ich/Unter den Blumen.//Im Arme der Götter Wuchs ich gross."
} 
Salvou-me um deus muita vez

Da gritaria e dos açoites dos homens,

E então brincava seguro e bem

Com as flores do bosque,

E as brisas do céu

Brincavam comigo.

Assim como alegras

O coração das plantas,

Quando elas te estendem

Os braços tenros,

Assim me alegraste o coração,

Hélios! E, como Endymion,

Era eu o teu amado,

Lua sagrada!

Ó vós todos, fiéis,

Amigos deuses!

Se vós soubésseis

Como a minha alma vos amou!

É verdade que então vos não chamava

Ainda pelos nomes, e vós também

Nunca me nomeáveis, como os homens se nomeiam,

Como se se conhecessem.

Mas conhecia-vos melhor

Do que jamais conheci os homens;

Entendia o silêncio do Éter;

Palavras dos homens nunca as entendi.

A mim criou-me a harmonia

Do bosque sussurrante

E aprendi a amar

Entre as flores. 
Foi nos braços dos deuses que eu cresci. (Hölderlin, 1800/1991, p. 105-106).

A palavra poética parece ser aquele dizer que procura acompanhar, em versos, a instabilidade da alteridade/diferença. Com palavras que surgem de um silêncio rompido, o poema celebra aquele dizer que ilumina o escuro da ausência da palavra, e carrega em seu bojo um interminável universo palimpséstico de sentido, quando pode abrigar, com profundo respeito, essa misteriosa fonte de onde a palavra parece surgir, nomeando nomes com aquele inevitável erro de nomear aquilo que não pode ser jamais inteiramente nomeado; essa fonte, que poderá até ser confundida com a nomeação, não é essa nomeação, muito embora possa ser esquecida na exuberância da palavra e do sentido. Na medida em que surge uma palavra, ela também conta, com sua instabilidade e incerteza, a profunda emoção de seu aparecimento; recria aquela experiência emocional que poderia apenas ser pronunciada se as palavras mantivessem-se simultaneamente precisas e imprecisas, instáveis e estáveis, incertas e certas, escuras e iluminadas. Não podemos nos deter demasiadamente numa palavra poética sem nos maravilharmos com o fato de que tais palavras, e somente essas, poderiam nos dizer o que tinham para dizer, daquela forma única, e, simultaneamente, que essas palavras seriam absolutamente frágeis e impróprias para dizer aquilo que diziam; isso porque elas certamente assinalam, como janelas, como ícone, o Real. Ainda, por vezes, o dizer poético assinala também justamente que a palavra parece ser um modo de desconhecimento daquilo que nomeia, como nesses versos do poema de Hölderlin (1800/1991):

\footnotetext{
[...]

É verdade que então vos não chamava

Ainda pelos nomes, e vós também

Nunca me nomeáveis, como os homens se nomeiam,

Como se se conhecessem.
}

Mas conhecia-vos melhor 
Do que jamais conheci os homens;

[...]. (p. 106).

Nesse primeiro verso, parece haver uma constatação por parte do poeta de um silêncio, de um silêncio do seu dizer; parece haver uma verdade que precisaria ser lembrada: a de que esse silêncio não era rompido por um chamado. No segundo e no terceiro verso, Hölderlin (1800/1991) diz-nos que esse chamado seria a nomeação, por um dizer, dos nomes dessas figuras inomináveis - que sabemos tratar-se de deuses, divindades. Ele não os chamava, não os nomeava; lembra-se de um tempo em que não os nomeava pelos nomes deles e que eles também não faziam assim; desse modo, não os chamava, não havia nenhum chamado por eles. Há, portanto, um silêncio que permanece como expressão de uma unicidade.

Nesse pequeno trecho, deparamo-nos com a abissal e simples testemunha de que, nessa unicidade, os nomes, a nomeação, parecem ser uma expressão humana que apenas indicaria o quanto há de desconhecimento, o quanto há de afastamento com essa divindade com que se pode estar em participação e unicidade. O resultado dessa reflexão é a apreensão de que conhecer pela nomeação é a expressão de um ocultamento pela aparente revelação da divindade. A divindade, assinalada por Hölderlin (1800/1991) nesse poema, é uma divindade silenciosa, uma divindade que está mais do que presente, está unida e o conhece, porque está com ele, e é por meio dele mesmo uma forma encarnada de seu acontecimento, do Real.

Poderíamos pensar - talvez acertadamente - que esse dizer poético é semelhante àquele dizer que é, na clínica psicanalítica, a expressão da apreensão da visitação do Real. Certamente, há uma diferença entre aquela expressão poética cuja função é ser uma expressão sedutora, portanto, dissimuladora, e essa outra apreensão. A apreensão do Real, na clínica psicanalítica, parece ser aquele esquecimento do esquecimento do Real ou aquele esquecimento da memória, da compreensão e do desejo, como dimensões em que ocorre determinação incessante de sentido, sejam sentidos pretéritos, presentes ou futuros. 
O estado mental de se estar sem memória, sem desejo e sem compreensão é, assim, um estado de esquecimento em que se sustenta pacientemente o desabrigo da ausência de sentido pretérito, presente ou futuro. Sustentar-se nesse desabrigo é, paradoxalmente, manter-se atento e profundamente sensível ao momento presente, como expressão daquele novo transitório e instável que jamais será novamente daquele mesmo modo, porque, sendo alteridade/diferença, sempre nos destitui daquela compreensão que havíamos tido de uma verdade emocional ou que gostaríamos de ter. Mas o que nos desabriga, paradoxalmente, lança-nos de volta às coisas, tornando essa experiência emocional uma palavra guardiã da ausência, tornando-a fonte daqueles acontecimentos que jamais poderemos apreender, senão resguardando essa distância que não pode ser suplantada, que nos separa, no desabrigo, da familiaridade das coisas, mas que nos mantém absolutamente admirados com a possibilidade de que, nesse silêncio, possamos inaugurar cada palavra, cada nome, como algo nunca antes pronunciado, e assim testemunharmos originalmente, pela pureza do silêncio que ronda a palavra, esse incerto luscofusco da experiência, que permanece, em uma noite escura, acendendo e apagando, transitório e instável, uma vez que nenhuma palavra captura-o por completo, senão por breves e falsos momentos, nos quais o transiente, o mais além ou o ponto ausente emudece, num emudecimento que torna cada expressão humana uma tentativa de destruição de sua profunda distância com cada coisa, que, dramaticamente, seria aquela possibilidade de uma nova criação poética da experiência emocional. No emudecimento do mundo, cala-se o mundo pelo dizer e não se conserva o tempo de um florescimento: o florescimento da palavra que resguarda aquela ausência de sentido e que, apenas por isso, é absolutamente incapaz de afirmar-se como uma palavra que dirá uma "palavra final”, uma palavra que sustente alguma afirmação unicamente estável e consistente, que não seja mergulhada na incerteza que mantém a interrogação como possibilidade para o aparecimento interminável da diferença, que inaugura em cada 
aparecimento a recriação poética do mundo humano, do mundo da experiência emocional humana, com sua instabilidade, fugacidade e transitoriedade abissais.

Mas haveria uma contradição entre a unicidade com a divindade da qual nos fala Hölderlin (1800/1991) e a distância que nos separa da familiaridade das coisas? Será que poderíamos pensar que essa unicidade seria justamente aquilo que nos mantém inevitavelmente distantes dessa familiaridade do mundo que nos cerca e que é familiar por manter-se como uma realidade aparentemente idêntica a si mesma, nomeada por seus nomes, tais como o nome de um pai, de uma terra, de pessoas ou de coisas? Nesse poema de Hölderlin (1800/1991), há o verso: "Como se se conhecessem", no qual o poeta diz, de modo absolutamente contrário ao nosso pensamento mais comum e mais familiar, aquilo que desde muito cedo somos familiarizados a conceber: que, ao dizer os nomes das pessoas e das coisas que nos cercam, parecemos nos conhecer e conhecer as coisas que nomeamos. Esse verso fala do assombro do poeta com esse simples e radical estranhamento, com esse estado de lucidez que revela a ele a maior penúria dos homens: seu distanciamento da divindade e sua ilusão de conhecer aquilo que designa com tanta familiaridade. Trata-se justamente de uma disposição em que se apreende estar "estranho dentro do ente". Aquilo que é familiar e nomeado, repentinamente, torna-se estranho.

O problema que Hölderlin (1800/1991) coloca não parece diferir muito de um ponto de vista psicanalítico: o analista tem também por objetivo que o paciente possa ser aquilo que se anuncia como sua realidade desconhecida, embora testemunhe a defesa frente à estranheza e ao desconhecimento radical. No final de seu poema, termina com o verso: "Foi nos braços dos deuses que eu cresci”, no qual nos diz que, embora não os nomeasse, embora não os conhecesse como os homens se conhecem, embora não compreendesse a palavra dos homens, ele cresceu nos braços dos deuses. Crescimento, como nos fala o poeta, não tem qualquer relação com conhecer; é algo que se espera que ocorra independentemente de haver um conhecimento sobre 
algo específico. Podemos até imaginar a necessidade evidente que, durante o crescimento, alguém deva obter inúmeros, intermináveis conhecimentos, mas conhecer não é o mesmo que crescer. Heidegger (1959/2004), no entanto, assinala-nos um sentido diverso para aquele que aprendeu, ou seja, não apenas conheceu:

Aprender significa: tornar-se quem sabe. Quem sabe é em latim qui vidit, quem viu e entreviu alguma coisa, de modo a não perder mais de vista o que viu. Aprender significa: alcançar essa visão. Para isso é preciso alcançar, estando a caminho, numa travessia. Fazer uma travessia, atravessar na experiência [Erfahrung] significa: aprender. (p. 177).

Hölderlin (1800/1991) fala-nos de um sentido de conhecer que denota aprendizado, um aprendizado pela experiência. Aprender experimentando e crescer estão intimamente próximos. Aprender algo é experimentar isso pela experiência e poder se tornar aquilo que se viveu, aquilo que se é. $\mathrm{O}$ aprendizado pela experiência denota crescimento, que é uma atividade que está absolutamente próxima da de ser. Crescer e ser estão em uma relação de parentesco, de vizinhança. Assim, o poeta pode dizer que cresceu nos braços dos deuses ao sentir que isso não era uma atividade dissociada dessa unicidade de seu próprio ser; a afirmação de Bion (1965/2004a), de que o máximo e o mínimo que o indivíduo pode fazer em relação à divindade são sê-la, parece ecoar aqui nesse momento. Hölderlin (1800/1991), em sua lembrança de um tempo que se passou, de um passado que recupera em versos, que agora podem ser escritos, guardiães desse silêncio que não precisaria ser quebrado, do silêncio da unicidade, diz-nos:

Entendia o silêncio do Éter;

Palavras dos homens nunca as entendi. (p. 106).

Seu entendimento, sua compreensão, ou melhor, seu aprendizado parece repousar numa base distinta da compreensão das palavras dos homens. O silêncio a que ele se refere, a 
unicidade com os deuses, era um sentimento de estar sendo nos braços dos deuses: ser amparado, no silêncio do desconhecimento, a ser e a crescer, sem precisar fazer qualquer chamado por isso; e era isso que permitia que ele fosse sendo e amadurecendo com essa presença divina. O chamado a que Hölderlin (1800/1991) refere-se muito se parece com um pedido ou um clamor. Esse clamor parece-se com um grito, tal como se faz com uma mãe ou um pai, quando se anseia por eles, mas o poeta diz que não chamava; ele se tornou unido a essa divindade, permitindo - simultaneamente - que ela viesse a lhe fazer crescer. Grotstein (2010), ao expor a visão de Bion sobre a psicanálise, diz:

Sua visão [a de Bion] de nossa tarefa é 'virmos a ser nosso O', ou mais propriamente, termos nosso $\mathrm{O}$, nossa divindade [...], encarnada em nós enquanto estamos no ato de sentir total e autenticamente ou em nossas paixões (emoções emergentes) - ou seja, nos tornarmos unidos ao $\mathrm{O}$ em eterna evolução que intersectou com nossos universos interior e exterior - para virmos a ser $\mathrm{O}$ permitindo que $\mathrm{O}$ venha a ser nós - sabendo o tempo todo que a tarefa exigiria um número infinito de vidas e ainda não seria bem sucedida [...]. (p. 49-50).

Mas não seria essa a expressão de uma visitação do Real? Podemos notar a diferença entre a descrição de Hölderlin (1800/1991) e a de um deus errante que faz sua morada em Tebas, naquela terra que nunca o venerou, tornando-a estranha aos olhos dos cidadãos. Não seriam esses cidadãos tomados de assombro, tal como Penteu, o rei arrogante, que não pôde tornar-se unido àquilo que clamava por ser e foi destruído por sua curiosidade ao espiar as Cádmias bacantes? Uma permanência da visitação do Real poderia significar que destituímos nomeações que tenham um propósito de dissimulação e, assim, somos e crescemos sob o impacto do Real que nos torna, cada vez mais, menos pessoais e mais próximos da alteridade/diferença, encarnando a infinidade em nós mesmos, “como uma tarefa infinitamente teleológica" (Grotstein, 2010, p. 54). Penteu parece ser a expressão dessa personalidade que é intolerante à transformação advinda daquilo que clama em nós por ser e, assim, torna-se 
curiosa, mas incapaz de sofrer a ruptura que a instabilidade da encarnação do Real demanda e provoca.

No entanto, Hölderlin (1800/1991), de modo absolutamente diverso de Eurípedes, descreve essa unicidade com delicadeza e placidez inigualáveis. Há, nessa unicidade, não uma tentativa obscura de dissimulação da castração, mas a manutenção da abertura para a linguagem e para o "outro quarto" na sua expressão da palavra poética. Sua perturbação frente à divindade parece ser atenuada em face da turbulência em relação à nomeação e ao mundo comum e familiar, tal como expressa em seus primeiros versos:

\section{Quando era menino}

Salvou-me um deus muita vez

Da gritaria e dos açoites dos homens [...]. (Hölderlin, 1800/1991, p. 105).

As gritarias e açoites dos homens pareciam ser aquela familiaridade que se mostrava inabitável e, com tal impossibilidade de habitar, um deus salvava-o. Mas como pode uma divindade salvar-nos a não ser na unicidade com ela, de modo que possamos nos tornar essa mesma divindade? A expressão dessa unicidade, em Hölderlin (1800/1991), parece-se com o resplendor e o maravilhamento da testemunha da presença de um encantamento do mundo após um mergulho no silêncio de uma intensa escuridão do Real. Essa afirmação pode, certamente, ser posta em dúvida, e é desejável que seja; para ampliá-la, encontramos em Grotstein (2010) uma aproximação a ela, no início de seu livro Um facho de intensa escuridão, em um momento em que justifica a escolha pelo título de seu trabalho:

Uma vez, após uma sessão analítica minha, Bion, incomumente para ele, foi até sua estante de livros, retirou uma edição alemã da correspondência de Freud com Lou Andreas-Salomé e leu para mim, traduzindo. Logo após, transcrevi: 'Ao conduzir uma análise, é preciso emitir um facho de intensa escuridão de modo que algo que até então tenha estado obscurecido pelo resplendor da iluminação possa brilhar ainda mais na escuridão'. (p. 15). 
Um facho de intensa escuridão parece ser aquela presença do Real que nos retira da familiaridade da palavra e do sentido, para nos restituir a alteridade/diferença, ou seja, a verdadeira distância em que nos encontramos, tanto das coisas quanto do Real. Com a manutenção dessa distância inexorável, permanecemos em tensão e instabilidade em face dessa condição de desabrigo em relação ao mundo e à palavra e em relação ao Real; trata-se de uma experiência que pode ser tolerada e, assim, ser uma evidência que aquilo que passa a brilhar foi iluminado com a escuridão do desabrigo do Real e será expressão dessa instabilidade da alteridade/diferença. Muito possivelmente, a experiência de Hölderlin (1800/1991), nesse "amigamento" com o silêncio, com o não falado dos deuses, com essa verdadeira unicidade, correspondia a uma experiência em que era possível obscurecer essa familiaridade, de modo a reencontrá-la após tê-la perdido; nesse reencontro, a familiaridade poderia ser reencontrada como diversa de si mesma, pois se mantinha, assim, como alteridade/diferença, ou seja, como pertencente não mais ao universo ôntico e não somente como ontologia.

A alteridade/diferença, desse ponto de vista, pode ser compreendida como o espaço produzido pela negação do ente e, simultaneamente, pela inospitalidade do Real. Ela é o espaço produzido pelo não, que faz com que a palavra fique corrompida pelo Real e, instável, possa ser costurada e tecida com outras palavras e sentidos diversos. Essa é a presença da alteridade/diferença. Com propósitos distintos, Heidegger (1949/1988) ampliou significativamente essa questão ao declarar:

O nada é o não do ente e, deste modo, o ser experimentado a partir do ente. A diferença ontológica é o não entre o ente e o ser. Mas assim como o ser, enquanto o não para o ente, não é um nada no sentido do nihil negativum, assim tão pouco a diferença, enquanto o não entre o ente e o ser, é apenas o produto de uma distinção do entendimento (ens rationis). (p. 9). 
A alteridade/diferença pode ser compreendida, desse modo, como a própria diferença ontológica, como esse não que é, portanto, a possibilidade do aparecimento da multiplicidade palimpséstica. Entretanto, na passagem de Grotstein (2010), há uma compreensão de que aquilo que está iluminado, de que aquilo que está em evidência, em aparição, pode ser simultaneamente obscurecimento e alienação, quando não parece surgir banhado pela escuridão do Real. "Obscurecido pelo resplendor da iluminação" (Grotstein, 2010, p. 15): nessa expressão paradoxal, somos convidados pelo autor a mergulhar em uma compreensão absolutamente diversa da ideia comumente concebida de que a realidade que a palavra representaria pode ser simplesmente a expressão revelada e inteira de uma verdade emocional. A palavra, que ilumina aquilo que existe, o ente, também permanece tendo com esse ente uma relação de ocultamento, ou seja, em cada palavra, em cada expressão, podemos pensar que iluminamos, em um resplendor de iluminação, mas, simultaneamente, sabemos que obscurecemos e deixamos sempre algo obscuro. A noção de aletheia resguarda muito precisamente essa mesma compreensão: um desvelar que, ao revelar, esconde a si mesmo, velando. Talvez possamos nos lembrar dessa mesma passagem, citada anteriormente, que agora pode alcançar nova profundidade para nós:

$\mathrm{O}$ velamento recusa o desvelamento à aletheia. Nem o admite até como steresis (privação), mas conserva para a aletheia o que lhe é mais próprio, como propriedade. O velamento é, então, pensado a partir da verdade como desvelamento, o não-desvelamento e, desta maneira, a mais própria e autêntica não-verdade pertencente à essência da verdade. (Heidegger, 1930/1984a, p. 39).

Nessa intrigante passagem, há a possibilidade de observarmos como é possível pensar a noção de iluminação da palavra de modo que a não iluminação ou a não verdade seja aquilo que é indissociável da própria essência da verdade. Há um velamento que se mantém como tal e se recusa sempre a ser desvelado, assim como um desvelado que pode manter-se como aquilo que 
não deixa de manter-se no resplendor de uma iluminação e que necessitaria da escuridão para iluminar-se de modo diverso. Não se trata de um conteúdo especialmente velado ou desvelado, mas da própria característica da aletheia. Certamente, os dois pensamentos conservam nítidas diferenças entre si; no entanto, observam, simultaneamente, a ideia da dissimulação oriunda do resplendor do desvelado e a tentativa de desvelamento daquilo que se conserva obscurecido. $\mathrm{O}$ obscurecido, em ambos os casos, parece ser aquilo que não é tornado palavra, não porque não possa se tornar palavra algo que seja obscurecido, mas porque o obscurecido é a autêntica não verdade que pertence à própria verdade. O obscurecido deve, assim, ser incluído na verdade da aparição, para revelar-se também diverso daquilo que se mostra. De qualquer modo, nosso interesse concentra-se, neste momento, em procurar descrever como a visitação do Real parece ser um processo de apreensão da obscurecida não verdade, como velamento, análogo àquilo que foi descrito por Bion (1965/2004a) como transformação em “O”.

A transformação em “O” difere-se das demais transformações por ser um acontecimento de unicidade ou de encarnação de “O”, ou seja: “através da encarnação é possível estar unido a uma parte, a parte encarnada da divindade.” (Bion, 1965/2004a, p. 162). Essa união refere-se à possibilidade de tornar-se essa mesma parte encarnada, essa "realidade" desconhecida, que o autor descreve como "divindade". A atividade psicanalítica dar-se-ia justamente no favorecimento dessa "encarnação" da divindade, em que o analisando pode amadurecer a personalidade com vista a deixar com que a divindade "consinta" ser encarnada nessa pessoa e, assim, ela se tornar ou vir a ser essa realidade da divindade. Esta é justamente uma transformação em "O”, que se diferencia das demais por ser a transição, tal como falamos anteriormente, de um "conhecer sobre" para "tornar-se". Do ponto de vista da verdade, ela apenas pode ser a apreensão da não verdade, ou seja, do velado e obscuro, que é indissociável, porém contraparte do conhecer e do saber. 
A divindade, tal como Bion (1965/2004a) descreve em Transformações, é particularmente próxima daquilo que viemos tratando até o presente momento, ou seja, trata-se de "trevas e ausência de forma, potencialmente contendo todas as distinções, mas ainda não desenvolvidas" (p. 168) ou, de um ponto de vista heideggeriano, daquela essência da verdade da qual o não desvelamento participa inexoravelmente. Em Bion (1965/2004a) também não se encontra uma ideia de que essas distinções possam ser inteiramente conhecidas. Tratando-se de transformações de "O" em "K", em objetos de conhecimento, essas distinções não deixam de ser ilusões que dissimulam o Real; ou nas palavras de Grotstein (2010):

Colocado de outra forma, o que comumente chamamos de realidade é em si uma ilusão que dissimula o Real $(\mathrm{O})$. Bion transpôs o véu de um modernismo constritivo, caracterizado como foi pela certeza determinista e introduziu-nos ao relativismo, à intersubjetividade e ao inefável. Para Bion, O é a questão atrás da questão que complica toda resposta. Contudo, ao mesmo tempo, O é a resposta não conhecível. (p. 132).

Ou talvez pudéssemos acrescentar e dizer: “O”, como Real, é a não verdade do velado no desvelamento, que corresponde à sua mais íntima verdade, independentemente de quanto se desvelem ou se desenvolvam as qualidades não desenvolvidas do Real. Essa relação estabelecida pelo autor com o Real não é a única em seu livro; para o autor, assim como assinalamos neste trabalho, a ideia de "O" presente no pensamento de Bion tem interfaces com o pensamento heideggeriano de Ser e do Real de Lacan (Grotstein, 2010). Gianesi (2011), por exemplo, seguindo o pensamento lacaniano, ao discutir sobre o lugar do acontecimento do trauma, assinala-nos:

O Real, enquanto o impossível, o que não cessa de não se escrever, mostra uma causa que subsiste ao não ser preenchida. Dissemos, assim, que o Real diz respeito a um tipo de ausência que o Simbólico não supre. O Simbólico o bordeia. O Imaginário faz vestes, mas o Real não surge como representação. (p. 335). 
Pensamos não se tratar de uma distinção à nossa maneira de expor a questão do Real. O Real escapa a toda tentativa de formalização, de representação positiva e de atribuição de sentido, muito embora aconteça como aquele acontecimento que destitui o sentido escrito e desancora. Seja como for, pensamos que Bion (1965/2004a), que nos fornece alguma forma de representação não positiva do Real, assinala-nos que as distinções feitas a partir de "trevas e ausência de forma" devem ser distinções realizadas pela possibilidade de pensarmos esses pensamentos que ainda não se tornaram, justamente, distintos. Entretanto, pensamos que a capacidade de pensar os pensamentos, que é uma atividade de transformação de "O" em " $\mathrm{K}$ ", reflete uma perda da unicidade com a divindade (“O”). Pensamos que apenas nesse sentido podemos compreender Hölderlin (1800/1991) quando nos diz que:

\section{$[\ldots]$}

Mas conhecia-vos melhor

Do que jamais conheci os homens;

[...]. (p. 105).

“Conhecia-vos melhor” (Hölderlin, 1800/1991, p. 106), nesse sentido, não é algo que se relacione exatamente com conhecimento; parece que, quando assim nos diz o poeta, ele expressa intimamente, silenciosamente, que estava uno com aquilo que não necessitava de nenhum conhecimento, com aquilo que prescindia de qualquer espécie de transformação. Ele era visitado pelo Real, que, encarnado, tornava-o parte das "trevas e ausência de forma". O Real, desse modo, visita ao ser encarnado; ele "torna" o analisando como a si mesmo, como a negatividade que, no entanto, contém aquelas qualidades ainda não desenvolvidas. Parece demandar ser justamente essas mesmas qualidades, que ocorrem por meio de preconcepções, de estruturas gerais diante das quais o Real pode acontecer. As demandas do Real, no entanto, 
parecem ser todas elas relacionadas com uma tentativa de esburacamento, de destituição da organização de sentido e de existência, tal como o eu mesmo comumente concebe.

É-nos especialmente intrigante formular que o Real é "trevas e ausência de forma”, ou uma negatividade que pode ser descrita por meio de acontecimentos que denotam orfandade, solidão, nada e desterro, e simultaneamente caracterizá-lo como aquilo que contém em si todas as qualidades ainda não desenvolvidas, ou seja, toda possibilidade de positividade da experiência ôntica, isto é, de termos uma terra, pessoas, paternidade e nossas coisas. Esse aspecto intrigante e paradoxal do Real leva-nos a pensar que, como formulamos anteriormente, o Real, ao retirar, também nos doa. A visitação do Real, assim, não deve ser compreendida como uma espécie de "silêncio do éter", desprovido de demanda e implicação. O "silêncio do Éter” do qual nos fala Hölderlin (1800/1991) parece ser esse estado da pura unicidade com o Real que é inevitavelmente perdido e, ao ser perdido, é geralmente estruturado como um registro da castração e, portanto, do ponto ausente, ou do "quarto ao lado" da alteridade/diferença, para o qual há a imaginação e a criatividade como modos de explicitação da presença-ausente do Real em nós ou de sua passagem que nos deixa suas marcas.

Hölderlin (1800/1991) mostra-nos, por meio de seu poema, aquilo que parece ser o mais simples: a impermanência da unicidade com a divindade. No entanto, mostra-nos também a permanência do sentimento da presença-ausente dessa divindade no momento de sua escrita, entranhada no interior de seus versos, como se as palavras do poema pudessem ser a própria evocação da ausência desse Real que se encontra novamente latente no espaço de cada palavra e de cada verso, pois cada palavra, cada verso e, por fim, o próprio poema parecem ser indicações da divindade e do sagrado. Parece nos dizer que ele está por aqui... embaixo ou através de cada palavra, e que será visto aqui ou ali!

Figueiredo et al. (2011) parecem resumir essa problemática com a seguinte passagem: 
Bion ainda se interessa pela modalidade cristã do platonismo e, neste caso, os fenômenos não são uma recordação das formas, mas uma encarnação da pessoa de Deus que permite ao sujeito uma reunião com Deus pela via das suas encarnações. Neste caso, vamos além de uma relação de conhecimento, pois a reunião se dá como participação e comunhão. É muito mais deixar-se habitar pela divindade, mediante o contato com a sua encarnação, do que conhecê-lo, indiretamente, pela via dos fenômenos que nos lembram das formas transcendentais. A experiência mística será, como veremos, um modelo para esta modalidade de transformação que já não é uma transformação em O, já não é um conhecimento de $\mathrm{O}$, mas um ser (tornar-se) $\mathrm{O}$. (p. 116).

Nessa passagem, os autores destacam o fato de que a reunião com Deus (ou divindade, ou “O”, ou o Real), longe de ser pela via do conhecimento, dá-se mediante um tornar-se ele mesmo. Esse "tornar-se" é, no entanto, deixar-se habitar pela divindade, tornar-se parte dela, e parte da divindade tornar-se existente. Hölderlin (1800/1991) assinala-nos justamente essa modalidade de transformação: um tornar-se a ausência do silêncio do éter para perdê-lo em algum momento e reencontrá-lo posteriormente, já de modo afastado, no poema escrito. Tornarse visitado pelo Real não pode ser descrito, desse modo, como um acontecimento perene; tratase, antes de tudo, de uma visitação, ou melhor, de um acontecimento que parece implicar uma passagem, mas também indica uma presença-ausente e pode, desse modo, ser indicado como um gerúndio, como um processo de ser ainda não finalizado, uma vez que as marcas desse Real parecem permanecer como aquela experiência inefável de ausência que reencontra a experiência presente não mais como um puramente dado, mas como multiplicidade e diversidade.

Seja como for, o processo de tornar-se esse Real, como um processo em que se torna o negativo do ente, o "escuro vazio e sem formas", é apenas parte de um acontecimento que ocorre na visitação do Real; o outro é justamente um processo ou movimento "construtivo", como nas palavras de Figueiredo et al. (2011):

Entre as duas acepções de $\mathrm{O}$ [de distinções não desenvolvidas que se desenvolvem ou evoluem e de um vazio e sem formas] há - sem que isso fique muito claro no texto - uma relação curiosa. Ser tornado por O parece implicar um movimento 'construtivo' em que O impõe-se com seu 
potencial de 'desenvolvimento'. Tornar-se O, entendido agora como infinito vazio e sem forma, é, ao contrário, um movimento desconstrutivo de retorno ao sem fundamento, às noites escuras da alma. No primeiro caso é o de deixar-se fazer por $\mathrm{O}$, no outro, é deixar-se desfazer em $\mathrm{O}$. (p. 144-145).

Esse duplo caráter de “O”, ou do Real, é profundamente paradoxal. Deixar-se desfazer no Real é, simultaneamente, deixar-se fazer pelo Real, aceitar e acatar sua demanda. A visitação do Real não pode ser compreendida senão por esse duplo aspecto: nela, o analisando deixa-se desfazer pelo Real e, simultaneamente, deixa-se fazer pelo Real. Mas o que se desfaz no Real e o que é feito pelo Real? Acaso as transformações cujos movimentos são em direção ao Real não implicam, simultaneamente, algo como uma "destituição subjetiva" do eu mesmo? Para Safatle (2009), é preciso considerar que:

Por fim, fica a idéia de que a temática da destituição subjetiva serve sobretudo para nos lembrar que: 'Os homens só são humanos quando eles não agem e não se colocam mais como pessoas; esta parte difusa da natureza na qual os homens não são pessoas assemelha-se ao delineamento de um ser inteligível, a um Si que seria desprovido de eu 'jenes Selbst, das vom Ich erlöst wärei'.'(Adorno, 1973, p. 267). Os homens só são humanos quando eles se reconhecem naquilo que não tem os contornos auto-idênticos de um eu. Pois só há sujeito lá onde há a possibilidade de reconhecer uma experiência interna de não-identidade. (p. 17).

Pensamos que essa passagem parece ser elucidativa no sentido de transmitir que o Real, em sua visitação, demanda-nos justamente essa transformação que se encontra no reconhecimento de que nossa humanidade estabelece-se na experiência do reconhecimento dessa não identidade, desse não mesmo que surge com a experiência de desfazer-se no Real. Mas o que se desfaz? Não seria justamente a ilusão de um ser cuja personalidade impõe-se como aquele eu mesmo tamponado pela experiência positiva com terra, paternidade, pessoas e coisas? Tamponado pelo infindável anseio daquilo pelo que clamamos como necessidade inesgotável e, ainda assim, jamais inteiramente realizável? Esse “desfazimento" da ilusão é uma 
destituição do eu mesmo, que se mantém envolvido na repetição incessante de seu mito pessoal, sem que possa pensar a experiência impessoal da autenticidade, ou seja, a manutenção, pela repetição, do mesmo. Nessa incessante repetição, não há a possibilidade de que se possa apreender aquela não identidade, que é marcada pelo obscuro rosto da infinidade, desse perecer que nunca perece, dessa constante passagem de um finito ao outro finito de maneira infinita, desse reconhecimento da infinidade do finito, ou seja, da alteridade/diferença.

$\mathrm{Na}$ autenticidade surgida pela destituição subjetiva, ocorre justamente aquele paradoxo da visitação do Real: ao se deixar desfazer, deixa-se fazer. Há, portanto, além de uma destituição, um ato positivo, uma demanda positiva do Real, a qual pode ser tanto compreendida como o próprio movimento de anseio por terra, pessoas, coisas e pais, quanto fazer-se aquilo que não se mantém nem no Real nem no ente. O lugar desse deixar fazer-se é o lugar da instabilidade paciente da própria diferença ontológica, ou da alteridade/diferença. O Real parece deixar fazer-se a multiplicidade palimpséstica do não mesmo, daquilo que é humano, de modo geral, como qualquer experiência possível aberta ao inefável; o Real parece deixar fazer-se aquela lucidez que resguarda o obscurecimento próprio da verdade e fazer-se unido àquela compreensão sem palavras que, pacientemente, convive com a solidão, o nada, o desterro e a orfandade, como o "nascente mundo de profundas, obscuras águas"; o Real parece também deixar fazer-se espera e pacientemente encontrar, por um ato de fé no Real como possibilidade de encarnar-se como mito, no meio do caudaloso e monumental universo sensorial e de estímulos desconexos, uma organização e coerência que se mantêm como incessantes aberturas e jamais como respostas e repetições do mesmo.

Nesse sentido, pensamos que a visitação do Real parece ser o caminho para que, por meio de sua presença-ausente ou de sua inospitalidade, possamos resguardar um lugar que parece ser o lugar de habitação da experiência humana de ilusão e, também, de multiplicidade: o lugar da alteridade/diferença, que é a própria diferença ontológica. Nesse espaço de diferença, 
há, simultaneamente, o ponto ausente do Real, que sempre nos convoca porque se mantém como aquele ponto que será sempre negado, inevitavelmente, pela sua impossibilidade originária, mas sempre a propagar suas ondas frias e monumentais de destituição e esburacamento no sentido. Por outro lado, na diferença da alteridade, o ente, como tal, não se mantém senão como uma constante negação e permanece na mais profunda inquietude de sentidos jamais inteiramente respondidos.

Pensamos que o lugar da análise é o lugar da diferença ontológica; na análise, um sentido não é encontrado em uma resposta, mas para a abertura para a lucidez que não finda. Há uma apreensão do analista de que se está no caminho de uma multiplicidade sem fim, mas que a análise é justamente a narrativa dessa multiplicidade; uma multiplicidade humana que está presente em cada homem e em cada mulher. O lugar do analista não é, senão, um lugar de comunicação inconsciente da possibilidade de permanecer na inospitalidade. O inóspito, o Real, deve ser aquela pura abertura que nos deixa ser possível negar o ente, não porque estamos num exercício obsessivo, mas porque, muito pelo contrário, encontramos em cada ente um buraco icônico, que nos leva para além dele mesmo e em direção ao infinito que não cessa de passar. Nesse encontro com o buraco do ente, ou com seu aspecto icônico, sabemos silenciosamente que nos direcionamos justamente para uma dimensão de multiplicidade de sentido inesgotável e que a verdade surge como uma revelação interminável, que resguarda justamente seu aspecto de não verdade ou de obscurecimento. Estamos, assim, em trânsito - trânsito e instabilidade - e envolvidos com a aparição não programada da multiplicidade palimpséstica.

No entanto, para que seja possível esse encontro com o buraco do ente na clínica psicanalítica, que possibilita, inclusive, pensarmos na dimensão interminável de uma análise, que não cessa, mesmo se acaso terminarmos uma análise propriamente dita, porque se trata da possibilidade de manter-se aberto à alteridade/diferença, parece ser importante pensarmos no lugar em que se posicionará esse analista que possibilita para esse paciente experiências 
intermináveis de encontro com a diversidade palimpséstica. Pensamos que Ogden (2010), quando comenta sobre a opinião de Borges sobre Shakespeare, de que parecia haver "um homem sem ninguém dentro de si”, aponta numa direção que nos parece ser a direção do analista que, por meio da possibilidade de manter-se tolerante à inospitalidade do Real, com a face que reflete não somente o outro, mas que pode refletir a própria escuridão do desabrigo do Real, no "facho de intensa escuridão", pode-se tornar sem ninguém em si; ou melhor, torna-se o Real da negatividade, que poderá apontar somente para a possibilidade do analisando de encontrar sua posição transcendente, ou seja, a posição da diferença ontológica, e, assim, "escutar" aquele chamado que lhe visita: a encarnação.

Poderíamos dizer que encarnar-se é se tornar aquilo que nos visita com um chamado transcendente e que clama por um engajamento naquilo que ainda não tem nome, não pedindo algo em troca; não sendo maior ou menor do que qualquer medida, mas destituindo-nos da mesmidade que nos tampona defensivamente, não obtemos, ainda assim, algo que se espere. Ao encarnarmos, tornamo-nos aquilo que nos destitui. Na destituição, podemos testemunhar a impessoalidade do Real tornar-se a resplandecência que ofusca e oculta a si mesma. Encarnarse, assim, é abrigar, simultaneamente, a finitude e a infinitude, a exuberância ofuscante do sentido que não satura mais a clareira cultivada pacientemente, porque se mantém sempre aberta para aquilo que ainda não nasceu.

O lavrador que roça cultiva o seu campo para colher os frutos da terra, que previamente lhe chama para o futuro, para aquilo que virá, pela necessidade de cuidar dessa clareira em que podemos compreender algo da finalidade da vocação; enquanto vocacionamos, somos engajados pelo chamado, que nos torna aquilo que podemos compreender de nós mesmos. Enquanto o lavrador trabalha, ele cultiva o futuro daquilo que, embora lhe convoque, ele ainda não pode testemunhar. Cultivar a clareira de um roçado - abrir o campo para poder fazer algo amadurecer, fazer crescer - é ser tocado pela impossibilidade de um dizer, pelo 
pensamento que, como semente, é aquele ainda não nascido e que está também além da possibilidade, além do possível, como uma alteridade ancestral, que em sua presença silenciosa mantém-se para o nosso futuro. Essa alteridade parece ser a presença do "há" daquilo que jamais encontrou uma saída para ser, que jamais pôde nascer e que, ainda assim, clama ao lavrador que cultive a terra, que plante as sementes, que permaneça engajado no cultivo do reconhecimento dessa alteridade/diferença, pois é a expressão daqueles não nascidos que, como gritos silenciosos, estão no ar. Mas trata-se, simultaneamente, daquilo que sempre será o próprio além do possível: a impossibilidade mais originária do Real.

O ar está cheio de gritos, falou-nos Beckett (1976); são os gritos dos não nascidos, sabemos nós. Seu desabrochar de frágil prematuro pode trazer aquele pressentimento da queda no esquecimento da ancestralidade impessoal e novamente inexistente dos não nascidos. O psicanalista lavrador cultiva essa terra dos não nascidos e cuida da ancestralidade, daquele coro que ecoa em nós, para o advento do chamado pelo reconhecimento da alteridade, um chamado que não pode ser senão testemunhado como um pensamento frágil, sem sentido e, simultaneamente, perturbador, como perturbadora alteridade que é, como um pensamento selvagem (Bion, 1997/2011) dificilmente existente como um pensamento narrado, que clama, na verdade, para ser, quem sabe, agraciado pela palavra poética, aquela que poderá, qual parteira cuidadosa, fazê-lo nascer nesse mundo de respostas, mesmo que pareça incapaz de crescer num mundo assim. Mas essa aparente fragilidade não pode ser subestimada: são os pensamentos do futuro, aqueles que - delicadamente - atingem-nos vertiginosamente e, na expressão poética, conservam para nós o alento daqueles territórios estrangeiros, que serão sempre impossíveis como morada, porém, pela palavra poética, eles se tornam habitáveis no dizer, que apenas surge de um campo arado e simultaneamente pobre; ou como nos diz Heidegger (1949/1984b): 
O pensar está na descida para a pobreza de sua essência precursora. O pensar recolhe a linguagem para junto do simples dizer. A linguagem é assim a linguagem do ser, como as nuvens são as nuvens do céu. Com seu dizer, o pensar abre sulcos invisíveis na linguagem. Eles são mais invisíveis que os sulcos que o camponês, a passo lento, traça pelo campo. (p. 175).

Acaso não haveríamos de nos tornar simplesmente agradecidos quando podemos presenciar o crescimento daquele inesperado, que surge pela terra como o mais improvável e desabrocha, ofuscando-nos de esplendor? Podemos apreender pelo facho de intensa escuridão, que tanto nos ofusca em sua beleza, que se promove uma completa revisão sobre a vida e o sentido mediano, abrindo-se sulcos na terra desolada pelo sentido endurecido, como sulcos invisíveis que tornam a terra mais preparada para o plantio e para o cultivo daqueles não nascidos: são sulcos na terra o fazer do analista, sereno obstetra que sabe fazer surgir das fendas a encarnação de uma nova vida para cada um de nós, pelo florescimento de sentidos novos embebidos da visitação de tudo o que "há", do possível e do impossível para sermos.

\subsection{Nada é sem Porquê?}

La rose est sans pourquoi, fleurit parce qu'elle fleurit, N'a souci d'elle-même, ne désire être vue. ${ }^{48}$

A. Silesius

Nossa intenção, neste momento, será aprofundar um pouco nossa discussão sobre o problema da "fundamentação" dos fatos clínicos psicanalíticos a partir da nossa compreensão sobre a visitação do Real, uma vez que, ao considerarmos o Real um território inabitável, a partir do qual podemos experimentar certas visitações da ordem do negativo, precisamos pensar no sentido dessas visitações para a clínica psicanalítica, principalmente para o trabalho clínico,

\footnotetext{
48 Trata-se da versão em francês traduzida do original alemão. A tradução para o português é: “A rosa é sem porquê, ela floresce porque floresce,/ Nem preocupa-se consigo, nem deseja ser olhada.” (tradução nossa).
} 
que tem encontrado na associação livre do analisando o caminho para a descoberta do fundamento do seu discurso. Caso consideremos que esse fundamento do discurso é um fundamento sem fundamento, ou seja, um fundamento sempre ultrapassado, como poderemos pensar o problema da associação livre e do determinismo psíquico? E por meio da noção de origem, ou seja, de um fundamento desprovido de fundamentação, essas noções psicanalíticas haveriam de ter uma nova perspectiva?

Poderemos observar que o título de nosso presente texto pode nos auxiliar, ainda, na tarefa de exame da pergunta que deu origem a ele: "nada é sem porquê?" Vamos considerar que essa pergunta está sendo proferida e que a oração "nada é sem porquê" pode ser tratada, por ora, sem sua interrogação. Trata-se de uma oração que pode ser compreendida inicialmente por: nenhuma coisa é sem uma razão, sem um porquê. O fato de que nada, nenhuma coisa, seja ou exista sem um fundamento faz com que entendamos que as coisas que conhecemos têm um motivo de ser, uma razão, e, portanto, uma explicação ou a possibilidade de um verdadeiro esclarecimento sobre elas. Nada do que existe prescinde de um motivo, de uma razão. Esta é, sem a interrogação, a expressão da formulação completa do princípio da razão suficiente: nada é sem uma razão suficiente que deve ser fornecida. Isso equivale dizer que um ato falho, um chiste, um sonho, um discurso ou, até mesmo, uma história, como a Gradiva, de Jensen, tal como observada por Freud (1907/2006v), tem uma razão, mesmo sendo essa razão um sentido de caráter inconsciente, que repousa em pensamentos oníricos recalcados provenientes da sexualidade infantil.

O determinismo psíquico orienta-nos nessa mesma direção, visto que ele explicita haver uma sequência de pensamentos determinados entre si por algo, uma razão ou um sentido inconsciente que o funda, para um sentido que é o seu porquê oculto e inconsciente. Nada na vida mental é arbitrário ou indeterminado: essa expressão de Freud (1901/2006x), presente na Psicopatologia da vida cotidiana, ilustra bem essa concepção. Há, metodologicamente, 
inclusive, na técnica psicanalítica, esse pressuposto - o do determinismo psíquico, proveniente de uma teoria causal - e ele faz com que orientemos nossa atenção sempre ao desconhecido, para uma fonte ou razão desconhecida do discurso manifesto, buscando os elos inconscientes de ideias, por exemplo, aparentemente separadas entre si. Bion (1965/2004a), ao discutir sobre o problema da validade de uma teoria psicanalítica da causalidade, escreveu:

A questão implica na validade de uma teoria da causalidade que considero enganosa, susceptível de originar construções basicamente falsas. Se a questão é enganosa, podemos descartá-la por outra, tão enganosa quanto - como na formulação, por Heisenberg, do problema da multicausalidade [...]. Em psicanálise fica difícil não sentir que sua extinção deixa uma lacuna que precisaria ser preenchida. (p. 73).

No entanto, mesmo correndo o risco de nos aventurarmos por ideias também enganosas e falsas, podemos ainda encontrar outro modo de leitura dessa oração: "Nada é sem porquê" pode também ressaltar, ter um acento ou um destaque em Nada, ou seja, podemos formular a oração do seguinte modo: "nada é sem porquê", dando a nada um sentido substantivado. Assim, poderemos ler essa oração do seguinte modo: "o nada não tem um porquê", ou seja, $o$ nada não tem uma razão de ser. Caso formulemos dessa forma a oração, podemos nos deparar com o problema que viemos criando até esse momento: o nada, como um aspecto negativo da visitação do Real, não tem um porquê, um motivo de ser. Isso significa, portanto, que o nada ou o Real não tem um motivo ou uma razão? Mas, afinal de contas, qual é então o “objeto" sobre o qual nos debruçamos? O Real? Ou os fatos clínicos psicanalíticos, os pensamentos, as histórias narradas, os sonhos etc.?

Bem, caso pensemos que nosso objeto seria as narrativas, por exemplo, então podemos nos haver com o fato de que elas teriam, como fenômenos, uma razão, ou melhor, que a razão poderia encontrar nelas um sentido, um motivo, uma explicação, ou seja, algo proveniente de seu modo de funcionamento, ao ir em direção a uma razão ou a um fundamento, onde poderia 
apenas existir o nada. No entanto, isso não é o mesmo que dizer que tais narrativas, por exemplo, teriam por si mesmas um motivo ou uma explicação final, totalizante, pois é a razão que vai ao encontro delas, para nelas achar um fundamento. Dizer, ainda, que o nada é sem razão significa dizer que ele é destituído de razão; que nele - no Real -, não há a presença de uma razão que lhe possa dar um porquê, um sentido. Trata-se, assim, daquele território estrangeiro, no qual o determinismo psíquico, como um instrumento de orientação e crença no desvendamento, na decifração, por meio de um encadeamento que se torna lógico pelo sentido latente e que desvela essa busca do porquê, não encontra explicação.

Podemos, portanto, pensar em duas concepções absolutamente distintas sobre o problema do fundamento: a primeira é que podemos encontrar, pela razão suficiente, as suas próprias razões, os seus porquês, que estariam fundamentados na própria razão, ou seja, nesse princípio que se caracterizaria como um princípio de intolerância da incerteza e de tamponamento da experiência emocional naquilo que há nela de necessário. Dizemos necessário e, por necessário, podemos nos valer daquelas palavras de Lacan (1972/1985b), que nos dizem ser o necessário aquilo que não cessa de se escrever, em contraposição ao impossível, que é aquilo que não pode, em nenhum caso, se escrever: que não cessa de não se escrever. Essa concepção do necessário parece ser descrita pelo autor desse modo porque não há como deixarmos de escrever, falar e formular sentidos e, simultaneamente, nesse ato de escrever, de dar um sentido ou proferir uma palavra; não há como não estar presente, mesmo como ausência, aquilo que não cessa de não se escrever, que, ao mesmo tempo, está lá como expressão mesma da própria aletheia, que já fora descrita por Heidegger (1930/1984a): o velamento que recusa o seu desvelamento no desvelado.

Com esse princípio de intolerância da razão, parece que fazemos com que aquilo que não cessa de não se escrever seja barrado, seja impossibilitado de ser apontado como o ponto de fuga para onde nossa atenção pode se mirar e se deter, mesmo que não possa ou não consiga ter 
uma palavra ou uma escrita que faça dele algo que se transforme naquilo que cessa o não se escrever. O que cessa o não se escrever é o mundo impossível do sentido e da resposta finalizadora, que é expressão de um aspecto da alucinação. A associação livre do paciente, por exemplo, revela-nos que isso que não cessa de se escrever, de se tornar palavra, também não cessa de não se escrever e de manter-se como esse ponto ausente, presente como obscuridade em todo sentido e em toda palavra manifesta, que é mais precisamente descrito como um: "Nascente mundo de profundas, obscuras águas/ arrebatado ao infinito vazio e sem forma", tal como foi descrito poeticamente por John Milton (citado por Bion, 1965/2004a, p. 176).

Isso que não cessa de se escrever é, assim, parte da origem, do Real, como algo que não cessa de urgir por ser, por tornar-se existência, pelo "hâ" levinaziano, que nos indica ser tudo aquilo que não se tornou ainda existente, mas que há, mesmo além de toda a figuração existente. O que urge por ser, mas que também não cessa de não se escrever, de não ser, de não se tornar palavra, existência e sentido, parece explicitar a tarefa teleológica do próprio pensamento, que não pode ser inteiramente pensado por manter-se como aquilo que se mantém velado, aberto e esburacado, como um obscuro impossível de se transformar em escrita, em palavra ou em sentido; nesse sentido, um impossível para nós.

No entanto, há no trabalho psicanalítico, desde seu início, um propósito implícito, o qual parece poder ser descrito como o de desvendar o desconhecido. Mas qual sentido poderemos dar, neste momento, para esse desvendar? Haveria, de fato, algo a ser desvendado para além da razão suficiente? Esse desconhecido, que poderia parecer ser o próprio fundo subjetivo, palimpséstico, no qual se assenta a investigação de nosso trabalho, parece-nos, neste momento, não ser subjetivo, tampouco um "fundo". Ao longo deste trabalho, nada mais fizemos do que pensar e repensar sobre esse "fundo", uma origem da reivindicação de um pensamento que anseia ser. O caminho que percorremos parece que pôde nos situar em relação ao assunto e nos assegurou poder presenciar aquilo que não é um alento ou um respiro para nossos pulmões 
quase sem ar, pois a "visão" desse "fundo", por meio de suas visitações, que nos fizeram constatar tratar-se de um fundo sem fundo, de uma ausência de fundamento, parece nos aturdir como um território inabitável ou um mergulho livre no oceano aberto de um profundo azul, sem redes, teias ou caminhos para a nossa orientação.

A crítica ao pensamento sobre o fundamento, que na psicanálise iniciou-se e ainda reside na ideia do recalcado, levou-nos a uma visão absolutamente transiente sobre a experiência emocional humana e nos fez ver que, no sentimento de verdade que ela resguarda por vezes o maior trunfo, o maior achado da clínica psicanalítica -, há também, em seu mais íntimo, a dimensão silenciosa de seu crepúsculo, pois, cada vez que presenciamos algo como verdadeiro, aquilo simplesmente, no momento seguinte, desvanece em nós e outros sentimentos e pensamentos podem reivindicar aparecer ou nascer. Desvendar o recalcado como essa verdade emocional conduz o pensamento a prosseguir em seu caminho e não a finalizar-se nesse desvendamento, como se fosse o derradeiro. Encontramos, portanto, na ideia do recalcado, uma forma de expressão do objeto formulado pelo princípio da razão suficiente, que enuncia, desde Leibniz, a assertiva de que não se tolera a existência de nada que exista sem que tenha uma razão. A razão da associação livre, nesse contexto, seria fundada no recalcado, como o sentido ou razão do discurso manifesto, da narrativa escolhida pelo narrador, na intolerância de seu fluxo interminável marcado pela presença daquilo que não cessa de não se escrever. Questionar o problema do fundamento, na psicanálise, significa, portanto, tanto ter que recolocar em discussão o próprio determinismo psíquico quanto rever a ideia do recalcado como determinação inconsciente do discurso manifesto.

O problema colocado pelo princípio da razão suficiente não é, portanto, um problema meramente filosófico ou da história da filosofia, mas de nossa época presente, da psicanálise e de certo modo de se pensar, que encontra nesse princípio expressão e força, como bem notou Heidegger (1962/1999), pois, além de ser um princípio de intolerância à incerteza e à falta de 
uma explicação, do pensamento não pensado, ele produz seus objetos, que podem ser colocados a serviço dessa mesma racionalidade, como bem notou Horkheimer (1955/2002) sobre a razão instrumental: "Seu valor operacional, seu papel de domínio dos homens e da natureza tornou-se o único critério para avaliá-la.” (p. 29). Seja como for, torna-se importante notar que as narrativas de histórias presentes nas sessões de psicanálise estão, aos olhos do analista - e também do analisando -, sempre envolvidas por esta ideia em comum: a de que aquela associação não é sem porquê, que há nela uma razão, no sentido de que se trata de algo que deveria, preferencialmente, ser desvendável e que, quando desvendado, será uma verdade viva, que irá, no entanto, fenecer, às vezes a contragosto da dupla. Testemunhar e permitir o amadurecimento do pensar, para que, por meio dele, possamos ser aquilo que reivindica ser, não é o mesmo que descobrir - investigando - o "fundo" sem fundo de nós mesmos, mas, mesmo na investigação analítica, que desvenda e, assim, atinge seu propósito, há a constatação, pela experiência, de que o atingido, logo em seguida, fenece como flores colhidas que, em um vaso por horas -, ainda exalam o perfume de sua origem, de um campo ou de certo jardim. As verdades emocionais apagam-se como fenecem as flores colhidas do vaso.

Esse crepúsculo e esse fenecimento do conteúdo da verdade emocional fazem dela, simultaneamente, exuberante e miserável, pois, quando pode nos oferecer a visão enigmática de um sentido que é repleto de valor, do próprio valor de uma verdade íntima, descoberta como joia preciosa em meio a um sem-número de palavras ditas sem um claro propósito, de nossa dimensão mundana e mediana, parece ser exuberante e também, quando nos devolve, na transitoriedade desse achado, a miséria de seu fim, de uma verdade que, embora nos alimente, não se conserva em nós como conceito, como imutável, nem sequer é passível de ser bem compartilhada com outrem, parece ser miserável. Desvendar o desconhecido, assim, parece ser poder apropriar-se desse caráter simultaneamente miserável e exuberante: trata-se de dar figurabilidade ao desconhecido, mas também de perder essa figuração logo em seguida. 
Conservar a figuração parece ser uma atividade humana das mais comuns e, mesmo na análise, ela, por meio da memória, ocorre com um propósito implícito de defesa da dupla analista-analisando de determinada experiência emocional desconhecida. A verdade retira-se inevitavelmente e não se conserva, senão como um ponto ausente, o ponto de fuga de um caminho. O recalcado, assim, quando é considerado a revelação proveniente de uma interpretação, não é mais do que uma imagem enigmática e surpreendente que nos remete a um olhar para além dela. Não desvendamos, com isso, simplesmente algo que estava oculto: o mais além, o ponto de fuga e essa verdade que se foi parecem ser aquele motor do movimento das sessões e o saturamos, infalivelmente, com um inevitável anseio por sentido e esclarecimento com uma interpretação.

Saturamos o Real, mesmo sem perceber, e produzimos narrativas em que acontecem teias de verdades que se dissolvem na noite. Parece que, a todo momento, na sessão, somos dirigidos a testemunhar como há uma experiência da verdade transitória e fugaz que é, simultaneamente, tão exuberante e necessária; mas, quando assim ela é, parece nos remeter a estranhas perturbações de nossa ordenação do mundo e do eu mesmo, principalmente pela constatação de que a sua transitoriedade remete-nos àquela falta de um fundamento totalizante da verdade emocional ou de um fundamento que, como origem, resguarde sempre sua dimensão de velamento que se recusa a ser esclarecimento, pois a verdade, quando somos achados por ela, não se encontra apenas na verdade relembrada de um evento esquecido e relembrado que é formulado em uma preposição, mas na capacidade que tem de oferecer o seu crepúsculo. Isto porque o conteúdo do sentido desvanece e, com esse desvanecimento, perdura somente a remissão desse sentido, que é, parece-nos, esse ponto ausente de onde poderão surgir novos pensamentos. Derrida (1995), em seu livro sobre a teologia negativa de Angelus Silesius, 
oferece-nos uma compreensão de hipérbole que, apesar de se distanciar do uso dessa palavra por Bion $(1965 / 2004 a)^{49}$, ilustra bem a questão:

\begin{abstract}
Hipérbole nomeia o movimento de transcendência que carrega ou transporta além do ser ou da 'sendidade', epekeina tes ousias. Esse movimento excessivo, o tiro dessa flecha em deslocamento convida a dizer: $X$ 'é' além daquilo que é, do ser ou da 'sendidade'. [...] X 'é' além daquilo que 'é', $X$ é sem (o) ser. (p. 48).
\end{abstract}

As ilusões, diferentemente, são formas cada vez mais bem produzidas por nós de nos apegarmos a uma plataforma firme dissimuladora, enquanto sentimos vertiginosamente nossos alicerces balançarem e o Real, inóspito e sem sentido, mirar-nos como um lugar de chegada em que não podemos chegar. A noite do sentido, em cada verdade emocional, a seu tempo, abate-se sobre nós. Isso poderia fazer de nós produtores sem fim de intermináveis análises, com o propósito equivocado de nos tornarmos uma máquina produtora de sentidos, uma máquina poderosa, que faria com que a face de nossa terra tornasse-se cada vez mais inundada e saturada por algo que deveria ser verdadeiro e por ideias que pretendem - por fim - lançar as teias mais duradouras, mais definitivas, de modo que tudo se torne passível de ser pensado, fazendo com que, aparentemente, a nossa própria existência seja inteiramente compreendida; assim, aquietarnos-íamos de nossa mais incessante e perturbadora inquietação: a de que realmente não sabemos nada que seja incontestavelmente uma plataforma firme sobre a existência humana.

O perigo dessa cooptação da máquina de sentidos, sabemos, reside em retirar o aspecto mais problemático de nossa visão: de que não queremos, assim, pelo Real, virar arte, estética e

\footnotetext{
49 Bion (1965/2004a), em Transformações, dá-nos um sentido absolutamente diverso para esse termo. Ele nos diz: "Quero que esse termo expresse uma impressão de exagero, de rivalidade, e retendo seu significado original, de arremesso e distanciamento. O aparecimento da hipérbole sob qualquer forma precisa ser considerado como significativo de uma transformação na qual estão operando rivalidade, inveja e evacuação.” (p. 154-155). De qualquer modo, guardadas as diferenças entre os usos da palavra, trata-se de um alerta feito pelo autor: até que ponto uma discussão sobre o problema do fundamento não se assenta em uma hipérbole, ou seja, em um arremesso distante e exagerado, com a finalidade de obter uma ajuda do continente, que deverá tolerá-la para fins de desintoxicação? Acaso a tentativa de obtenção de um fundamento em X, ou na coisa em si kantiana, não é expressão mesma dessa hipérbole, em que $\mathrm{X}$ é a representação desse continente?
} 
obra. Mesmo a mais tradicional visão psicanalítica, de que somos, nosso eu, objeto de determinações inconscientes que nos sintomatizam, que nos levam a cometer atos falhos, a falar e a escolher caminhos que não sabemos ao certo quais são; mesmo essa visão, que já seria suficiente para escutarmos um movimento transgressor de abertura ao recalcado inconsciente de nós mesmos, tem servido paulatinamente a que tentemos obter nosso domínio do eu mesmo, relacionando-nos com o inconsciente como se ele fosse algo a ser compreendido e, assim, dominado e posto a serviço de nosso querer, por meio de um movimento paranoico e investigativo. Não conseguimos, com isso, tornar-nos aquilo que o Real conclama-nos a ser: a multiplicidade e também a riqueza de sua expressão infinita e aberta, que nos despossui para nos oferecer a sua exuberância, fazendo-nos sua expressão encarnada.

O nosso mundo recriado pelo Real não pode tornar-se, assim, uma transfiguração, na qual nos tornaríamos, por sua vez, obra de arte: uma obra aberta. Tornar-se obra de arte é consentir manter-se em um movimento nas sessões em que aquele disruptivo, inóspito e exuberante será simultaneamente aquilo para o que estamos preparados, amadurecidos para ser. Esse movimento de ser não é, como sabemos também, finalizante, totalizante ou a constituição de uma nova identidade; é permitirmos, pelo amadurecimento da análise, uma abertura para o coro que pode cantar em nós, como uma música composta dos mais variados instrumentos, das dissonâncias e variações entre eles e, inevitavelmente, de silêncio e espaço, onde todo o coro da multiplicidade palimpséstica pode, como um pano de fundo de histórias, encontrar um narrador que a narre, escolhendo, possivelmente, uma narrativa que se abra para todas as histórias e que possa tecer entre elas as ligações que as tornam infinitas.

Perguntamo-nos, portanto, como fazer uma transmissão possível sobre a psicanálise a não ser promovendo o caminho de um pensar que revele nossos achados, nossas experiências emocionais. Mas poderíamos advogar por uma falta de porquê, por uma falta de razão nessa transmissão? Qual seria o propósito da transmissão, se não houvesse um porquê? 
A transmissão da psicanálise talvez se origine do sentimento de verdade que ela traz, na revelação desse pano de fundo de histórias, que parece flutuar naquilo que nos desabriga; a transmissão parece ser a transfiguração e a exuberância de um novo acontecimento de alteridade, pela possibilidade de passarmos adiante aquilo que nos tornou palavra. A transmissão da psicanálise parece, por um lado, ser uma transmissão capenga, falha, uma transmissão que almeja falar daquilo que não pode e pede o testemunho nos outros da verdade emocional que experimentamos, no ato de sermos obra: daquele ser que se faz nascer para depois fenecer novamente na sombra do esquecimento, após ter se mirado repentinamente no espelho de outrem e, nesse espelho, alcançar uma figuração que logo acabará. Ela pede, muitas vezes, o continente alheio, por poder ser, também, hiperbólica. Sófocles, com suas peças, bem o sabia: o espectador sente as dores das narrativas, por meio dos atores, como se fossem as suas próprias dores e, assim, podem contê-las. Uma experiência emocional psicanalítica é, desse modo, expressão da linguagem poética, simplesmente porque pode nos retirar daquela familiaridade que nos aliena no conhecido e nos perturba, embaçando a exuberância e a miséria de cada verdade, e também porque a linguagem poética pode ser aquela expressão da alteridade/diferença. Por outro lado, a transmissão deve poder realizar um caminho não somente da criação de emoções no interlocutor, que precisaria desintoxicar emoções primitivas de caráter projetivo, mas encaminhar a palavra também para a sua origem, ou seja, para aquele "fundo" sem fundo que justamente parece estar alheio aos "porquês". A transmissão, assim, parte da origem, do Real, e, após ter transformado-a em narrativa, encontra na forma poética um modo de remissão e de retorno ao ponto ausente e àquilo que, na palavra, não cessa de não ser palavra. Há, portanto, na transmissão da psicanálise, uma dupla via: do Real para a palavra e da palavra, simultaneamente, para o Real. Aquele que cria essa passagem está, de algum modo, participando de uma linguagem que recebe e transmite, sem que precise, de algum modo, permanecer nela como eu mesmo; ele parece, no entanto, ter que, de algum modo, contê-la e, 
assim, transformá-la em uma linguagem capaz tanto de dar figuração quanto de conservar esse ponto ausente, icônico, de remissão. Trata-se, assim, da possibilidade de ser passagem, de ser, na linguagem lacaniana, um "passador"; passar a palavra furada pelo negativo, pelo nada, que “continua a (não) existir na filigrana das coisas.” (Baudrillard, 2002, p. 14).

Em nosso fundo sem fundo, no Real, como origem, há também a descoberta de uma dimensão ética que não pode ser esquecida por nós; dela podemos vislumbrar a direção que pode tomar um trabalho psicanalítico quando, no limiar da travessia sobre o abismo, na destituição do eu mesmo, podemos ajudar para que nossos analisandos possam não só suportar tal trajeto, mas presenciar que, diante do abismo, no aspecto mais miserável e ermo de nossa condição, algo como a radiância e o resplendor etéreos de cada palavra parece ser uma doação transfigurada do aparecimento da verdade, em nossa reconciliação com o inefável, como expressão de nossa expansão, e surge decorrente da tolerância à visitação do Real. Trata-se da reconciliação com o Real pela escuta e correspondência a essa visitação, que, ao destituir-nos, também nos doa aquilo que seremos, como uma expressão rica e agraciada pelo testemunho manifesto da miséria da quaternidade negativa. Silesius (citado por Derrida, 1995), marcado pela tradição apofática do catolicismo, escreveu algo que se aproxima dessa compreensão:

Nada se torna que seja de antemão: se tu não

Te tornas (o) nada,

Jamais tu terás nascido da eterna luz. (p. 19).

A eterna luz pode ser compreendida como a luz que nasce da escuridão da ausência de formas, da iluminação do pensamento que aparece quando a negação do sentido, do familiar e da palavra que não cessa de se escrever foi consentida. Essa negação é expressão do acontecimento da visitação do Real; trata-se daquilo que já descrevemos como o facho de intensa escuridão, que faz resplandecer uma nova descoberta, mas trata-se também de uma 
transformação em "O", em que "O" é o nada que revela o nascimento de uma luz, de uma transfiguração do ente, agora marcado por esse acontecimento. Esse nascimento parece ser o nascimento pela correspondência de um pensamento que surge já transfigurado, após a sustentação na ausência do Real. Essa reconciliação, assim, significa deixar que ocorra certo acontecimento que produz esteticamente um sentimento de verdade e de beleza naquele que sustenta esse "nascimento". Como nos diz Akhmátova (2009, p. 117):

\section{$[\ldots]$}

E à tua volta cantou o silêncio

e um sol muito puro clareou a escuridão

e o mundo por um instante transformou-se

e estranhamente mudou o sabor do vinho.

E até eu, que fora destinada

da palavra divina a ser a assassina,

calei-me, quase com devoção,

para poder prolongar esse instante abençoado.

O caminho da análise é o de corresponder a esse apelo, que, mesmo no desconhecido do além do caminho, faz com que a dupla envolva-se nesse curso e também, eventualmente, nos seus descaminhos - na sua errância -, que é a alienação por um dos mundos impossíveis. Há, pensamos, um posicionamento ético do analista que sustenta tal posição: ele permite não apenas as rupturas próprias da emergência da alteridade/diferença, proporcionando, com elas, saltos de expansão no analisando, mas também o amadurecimento da personalidade do paciente, que pode continuamente experimentar nas sessões o desabrigo da destituição do Real, que recorrentemente reivindica e conclama. O analista, assim, torna-se aquele que sustenta o analisando nessa situação, por poder, primeiramente, manter-se nela - "prolongar esse instante abençoado" (Akhmátova, 2009, p. 117) -, como também aquele que pode ajudá-lo na tarefa de saturação, quando se corre o risco da permanência na escuta do silêncio que não se torna escuta 
e palavra. As experiências emocionais da dupla, desse modo, podem ter esse pano de fundo: o da tolerância na serena paciência, que perdura mesmo no esquecimento do esquecimento do Real, na abertura que nada desvenda, mas que é, simultaneamente, a disposição para, eventualmente, aquilo que urge por ser, que "hâ", vir ao nosso encalço e encarnar-se como uma escrita, uma palavra ou um sentido que abriga também aquilo que nele não cessa de não se escrever.

Nesse posicionamento ético, encontramos o analista sustentando a sua destituição e também cuidando do aparecimento daquele pensar incerto e, estranhamente, alheio àquilo que é conhecido de ambos; nessa posição, há um espaço transiente, um "entre" mundos, no qual pode ser difícil se equilibrar. Nesse sentido, torna-se importante atentar para aquelas construções falsas que poderão surgir com a intenção de aliviar a dupla da iminência de terror pelo negativo, pelo terror daquilo que não é nomeável, para assim poderem produzir conjuntamente narrativas alienantes e dissimuladoras. Trata-se, assim, de não apenas poder analisar ou interpretar “O”, transformando-o por um modo de se pensar que resguarde sua dimensão de abertura para aquele além de si mesmo, seu ponto ausente, mas de ser "O", ou o Real, ou de se estar em "O”, no Real, e ser por ele convocado e demandado.

Poderá o analista entregar-se não ao desejo de desvendar algo que esteja oculto, mas a uma tarefa de corresponder a um apelo do pensamento, para que aquilo que advém possa encontrar vigor em uma linguagem que permite estar permeada, perpassada pelos espaços necessários que se deve dar para algo vir a ser? Acaso essa entrega não se tornará a abertura silenciosa para a escuta de um apelo que clama por surgir e que, nesse clamor, também satura e arrisca a nos desencaminharmos dessa escuta, desse apelo que não cessa de indicar um caminho? Não seríamos, assim, nós, analistas, guardiões desse caminho que corresponde justamente à escuta e à correspondência a esse pensamento que reivindica um pensar que o receba, sendo assim existente como caminho e experiência emocional? Mas isso não é, 
simultaneamente, enfrentarmos a nossa maior miséria, a nossa maior destituição? Permanecermos nessa correspondência significa, portanto, não esquecermos que se trata de um caminho entre mundos impossíveis, um caminho que, como qualquer outro, recusa-se a delinear-se como inequívoco; trata-se, assim, de um caminho incerto e ele, como o caminho de uma análise, não só torna-se por vezes um caminho errante, como inaudível em seu apelo interminável, por tratar-se de uma pluralidade de reivindicações que não se tornam, de forma alguma, apreendidas por nós e, também, passíveis de serem contadas por meio de uma única história narrada. Se o interminável de uma análise pode ser a tentativa sem fim de figuração do apelo do Real, por outro lado, o terminável parece ser o risco de tornar inaudível esse apelo sem fim. Cabe a nós, assim, permanecermos pacientes para o reencontro e a reconciliação com esse caminho, diante do reconhecimento da nossa errância, mas, mesmo na errância, devemos nos perguntar em que medida não estaremos na presença do esquecimento do Real, alienados na formosa exuberância de um sentido que quer fundar-se como uma plataforma firme. Recuperar o caminho de uma análise seria, assim, recuperar a lembrança desse esquecimento e poder paulatinamente esquecê-lo; e, nesse esquecimento, advêm, pelo negativo, o apelo do Real e a sua visitação.

Nessa visitação, pela sua destituição e, simultaneamente, pela escuta de seu apelo, somos encaminhados a ser obra de arte aberta e indeterminada em relação a seu futuro, à sua realização. Ser obra de arte é, no entanto, tornar-se, mesmo na errância de um caminho, aquilo que reivindicou uma realização e pode surgir e ser como nosso próprio ser. Uma obra de arte não é um produto final, mas uma composição estética que está e se mantém aberta para a sinalização e indicação do seu caminho, um caminho da alteridade/diferença; o caminho da tempestade, um caminho de expansão, de ruptura e simultaneamente de amadurecimento, parece o caminho que suporta dar passos à frente, mesmo quando a terra abre-se sob os nossos pés, para a formação interminável da obra de arte que não está sob nosso domínio ou vontade. 
Ela ocorre com a linguagem esgarçada e furada. Assim, convém pensarmos, hoje, para a psicanálise, nesse problema da linguagem, mas é justo que pensemos, também e anteriormente, se estamos preparados para tal empreendimento. Tornarmo-nos obras de arte pela correspondência ao apelo do Real que nos destitui e, assim, obtermos uma linguagem condizente a esse apelo podem ser, no entanto, uma tarefa que ainda se mostra, para a psicanálise, a ser realizada em um porvir indeterminado. Talvez a psicanálise ainda precise descobrir sua própria linguagem, condizente com aquilo que está sendo, pelo pensamento, solicitado a ela, pois ainda não será no dia de amanhã que poderemos revelar nossa terra, como morada, poeticamente, tecendo pensamentos luminosos que possam fenecer como obras dissolvidas no escuro da noite mais primordial, e assim tolerar a transitoriedade da sua exuberância e a ausência de sentido de seu fim, uma vez que, desse modo, seríamos apenas um meio, um "entre", uma passagem, que certamente nos levaria para uma nova revolução copernicana. Esse estado pode ser, ainda, o do mais aflitivo desapego: aquele da esperança da iluminação inesperada em meio à escuridão; ou como nos disse Akhmátova (2009):

\footnotetext{
Vivo como o cuco no relógio

não invejo os pássaros do bosque.

Esta missão me foi dada e eu canto.

Sabe, destino semelhante,

Só a um inimigo poderia desejá-lo. (p. 58).
}

Poderíamos, assim, desejá-lo aos mais queridos? Mas, ao mesmo tempo, como não desejá-lo, se é desse destino, dessa correspondência, que poderá advir o trabalho analítico que, como um farol, orientar-nos-á verdadeiramente pela escuridão, por meio da escuta desse apelo e dessa reivindicação do pensamento que ocorrem sustentados pelo nada, pelo Real? 


\section{CONSIDERAÇÕES FINAIS}

Cada obra confia a seu escritor a forma que busca.

J. L. Borges

Ao longo deste trabalho, deparamo-nos com a ideia de que, se há algo que não cessa de se escrever e de se tornar palavra, escrita e sentido autonomamente por meio de nós, esse algo é acompanhado por aquilo que também não cessa de não se escrever - por sua impossibilidade e que jamais se faz e se esgota em palavra, escrita e sentido. Essa constatação faz-nos perceber, agora, que a nossa produção do texto, como expressão daquilo que não cessa de se escrever e que poderia prosseguir infinitamente, como uma infinita interlocução entre pensamentos variados, de múltiplas fontes, que se faz diante de um centro desconhecido - um centro que não se escreve - e que se torna também uma expressão das palavras que foram reivindicadas para nosso pensar antes mesmo de elas se tornarem articuladas em uma narrativa, é tanto o fruto do acolhimento dessa demanda quanto daquilo que não cessa de não se escrever em nós; ambas as dimensões são articuladas como as vestes tecidas sobre o informe e infigurável Real, assim permanecem unidas, se puderem ser pensadas e experienciadas como ocorrências unidas e articuladas.

Além delas, há a dimensão, ainda presente no texto, daquilo que (ainda) não pode se escrever. O que não pode (ainda) se escrever aponta-nos para os pensamentos não nascidos, para aquilo que jamais reivindicou um pensar, para os sonhos jamais sonhados, para os gritos silenciosos nunca eclodidos ou que foram interrompidos e que jamais se tornaram gritos de alguém; para aquilo que, como um grito mudo que ecoa e atravessa o mundo, não pode ser contido em parte alguma e se mantém como uma expressão ainda impossível, embora não essencialmente impossível. O que não pode (ainda) se escrever é algo que "há" e que não se tornou uma existência, e esse registro do ainda não pensado parece se opor de modo radical 
àquilo que cessa o que não se escreve, ou seja, que produz uma escrita alienante, por meio de formulações fixas, de verdades absolutas desprovidas de abertura ao desconhecido, do ainda não pensado; o que cessa o que não se escreve opõe-se tanto ao não pensado quanto ao que não cessa de não se escrever. Por fim, pensamos que talvez seja necessário formularmos que o acontecimento do Real, que destitui aquelas escritas que tendem a cessar o não se escrever, parece poder, como um acontecimento, ser o prenúncio de uma palavra poética ou $o$ que se escreve do que não cessa de não se escrever: um registro ou apontamento pela palavra ao Real, por meio da reivindicação de uma palavra que se torna poética.

Iremos pensar, agora, sobre essas cinco dimensões do nosso texto, que procuraremos analisar, articulando especialmente a relação entre aquilo que é impossível de se escrever e aquilo que não pode (ainda) se escrever, termos inspirados pelas fórmulas das categorias modais de Lacan $(1972 / 1985 b)^{50}$.

\section{Que Não Cessa de se Escrever}

Aquilo que não cessa de se escrever ocorre na própria narrativa que o comporta e o sustenta, com sua multiplicidade de sentidos e de histórias escondidas, apagadas ou ainda não desenvolvidas. As narrativas, que nunca chegam a um fim, parecem ser a tentativa da organização do pensar em face da multiplicidade simétrica dos pensamentos oníricos inconscientes; uma organização que procura suprimir e selecionar para obter uma expressão compatível com o processo secundário e com as leis do pensar. Nessa supressão, que é uma inevitável alienação da multiplicidade, as histórias vão sendo narradas em sucessão, de modo

\footnotetext{
${ }^{50}$ Lacan (1972/1985b) desenvolveu, em seu seminário Mais, ainda, a ideia de que haveria a presença do real no simbólico e, para tanto, formulou as suas categorias modais, uma referência aos termos da teoria aristotélica das modalidades. Em sua formulação, ordenou essas modalidades como: o necessário, o possível, o contingente e o impossível. Como nos mostra Gianesi (2011), em seu livro Causalidade e desencadeamento na clínica psicanalítica: "o necessário é aquilo que não cessa de se escrever, o possível é aquilo que cessa de se escrever, o contingente o que cessa de não se escrever e o impossível, o real, conforme postulou Lacan, aquilo que não cessa de não se escrever." (p. 146, nota 12).
} 
que se tornam impossibilitadas de serem contadas simultaneamente, um limite de nossa linguagem assimétrica comum. Atos falhos, chistes e outras expressões heterogêneas oriundas do desejo inconsciente parecem se referir àquelas outras histórias que estão sendo narradas simultaneamente sem que o narrador perceba e apontam para aquilo que não cessa de se escrever como uma dimensão plural e palimpséstica.

O que não cessa de se escrever é a narrativa esgarçada pela multiplicidade palimpséstica e simétrica, que acha - na eclosão de sua heterogeneidade - suas formas de expressão divergentes e autônomas, que repetidamente encontram modos de aparecimento, aparecimentos repetitivos e aparentemente sem sentido. Podemos dizer, assim, que a narrativa do narrador é, em certa medida, distinta daquilo que não cessa de se escrever, pois o que não cessa de se escrever ocorre como uma escrita divergente do desejo inconsciente, plural, palimpséstico e simultâneo à palavra do narrador; refere-se, especialmente, à descrição freudiana dos pensamentos oníricos latentes, em contraposição ao pensamento e conteúdo manifesto da história narrada. Em outra medida, se podemos dizer assim, a narrativa do narrador é também a expressão sempre parcial de aspectos dessa escrita que não cessa de se escrever.

O que não cessa de se escrever é uma narrativa autônoma imposta ao narrador pela existência simultânea de inúmeras camadas de pensamentos oníricos inconscientes que buscam sua expressão e sua realização. Por serem heterogêneos, trata-se de pensamentos que se impõem como divergentes em relação à familiaridade do eu mesmo sobre seus aparentes contornos e limites.

Beckett (1961/2010) descreveu, em Dias felizes, uma angustiante história, na qual seus dois personagens - Winnie e Willie - vão sendo levados, puxados, tragados para baixo, para a terra, enquanto procuram se agarrar desesperadamente àquilo que ainda têm à mão fragmentos de memórias, histórias antigas, utensílios, pensamentos dispersos e modos de 
entretenimento. Eles parecem se agarrar àquilo que, para eles, é um universo familiar, mas continuam em queda, envolvidos pela terra. Podemos dizer que há uma analogia possível entre ser puxado para baixo, engolido pela terra, tal como ocorre com os personagens de Beckett (1961/2010), e ser envolvido pelo espaço sem fim; ambas as situações apontam-nos para o risco de sucumbirmos diante de algo que nos desfaz, que nos destitui, que nos leva para a dimensão da difícil caracterização do esmaecimento dos contornos do eu mesmo.

Aquilo que não cessa de se escrever parece ter, nesse mote - a angústia da destituição dos contornos do eu mesmo -, o seu movimento, tal como tivemos a oportunidade de descrever em nosso trabalho. O que não cessa de se escrever justamente se opõe ao aparecimento dessa mais radical diferença, sobrepondo-se a ela com a heterogeneidade dos pensamentos oníricos inconscientes, mas, de outro ponto de vista, podemos afirmar que os próprios pensamentos oníricos inconscientes, plurais e palimpsésticos são formas de ampliação, pela heterogeneidade - ou seja, pelo primado da diferença -, do eu mesmo. Em outras palavras, dizemos que o desejo inconsciente, plural e multifacetado impõe-se como uma proteção - da sexualidade - ao aparecimento da radical alteridade/diferença inominável do Real ou, mais precisamente, ao acontecimento do Real que nos destitui na quaternidade negativa. O que não cessa de se escrever é necessário para recobrir o Real por meio da narrativa, que se torna uma narrativa contingente, dissimuladora.

Ser tragado pela terra e, ao mesmo tempo, permanecer tentando se segurar em "coisas" que parecem nos oferecer contornos positivos sobre nossa própria personalidade, tal como uma paternidade, uma nacionalidade, objetos pessoais ou amizades, parecem ser atitudes tipicamente humanas, em face do horror que pode sobrevir diante da angústia de sermos visitados pelo Real. A necessidade (ou anseio) é necessária, pois é a forma encobridora do Real. A necessidade de quaternidade positiva é necessária, uma vez que por ela se encobrirá, assim, a quaternidade negativa do Real. No entanto, mas, antes mesmo de apontarmos para 
essa dimensão do Real, em que podemos vislumbrar mais precisamente a dimensão do impossível e da possibilidade daquilo que não pode (ainda) ser escrito, precisamos compreender que a narrativa comporta, ao mesmo tempo, aquilo que não cessa de se escrever, que é a dimensão plural e heterogênea da escrita que se faz presente para o narrador, e aquela dimensão cotidiana da fala manifesta, do que se pretende dizer: o contingente.

O que se pretende dizer, o conteúdo manifesto da fala, é também o meio pelo qual a narrativa acontece e o meio pelo qual aquilo que não cessa de se escrever pode ter sua expressão como heterogeneidade, como estranho (Unheimliche) e como negativo. O que não cessa de se escrever parece ter sua expressão, porém, como já apontamos, pelo fato de que se faz uma heterogeneidade que se impõe no caminho da visitação do Real e essa heterogeneidade é garantidora do prazer para certa instância psíquica. Há, nesse sentido, uma vestimenta do Real, por meio daquilo que não cessa de se escrever. Podemos utilizar uma citação já usada de Gianesi (2011) para dizer, quase em acordo com ela, que há um imaginário que faz as vestes e se empenha por orná-las, enquanto o Real, o impossível, o que não cessa de não se escrever, subsiste e resiste a esse encobrimento, mesmo sem porquê, sem “causa", uma "causa" Real...

\section{O que Não Cessa de Não se Escrever}

Nas sessões de psicanálise, o Real, que se revela como um acontecimento desancorador, parece ser um visitante inesperado e sem figuração que se passa, por vezes, desapercebidamente, como um pensamento que não se torna pensável, que não se faz existir de modo figurado e que acontece em nós criando uma presença disruptiva, sentida como a alteridade/diferença daquilo que era experimentado e compreendido como um sentido outrora 
familiar e comum: com o Real, rompe-se aquilo em que nunca vemos nada como uma primeira vez - o cotidiano (Blanchot, 2007).

As visitações do Real, visitações do negativo, ou seja, do nada, do desterro, da solidão e da orfandade, destituem-nos de toda apreensão da realidade que queira estabelecer-se como puramente positiva. Assim, cada escrita pode ser compreendida como estando necessariamente acompanhada por sua possibilidade de ser visitada por essas caracterizações ontológicas, por uma desancoragem, que a faz, com esse acontecimento, destituída de seu sentido pretérito. Levada para além de si mesma, levada para além do que não cessa de ser dito, levada para a sua própria negação, para seu apagamento ou para aquilo que não cessa de não ser dito, a escrita torna-se, fatalmente, uma escrita incompleta ao vislumbrar essa dimensão de seu inevitável inacabamento, e essa incompletude que é impossível de completar é a sua própria verdade.

Pensamos, em certo sentido, que estamos descrevendo uma psicanálise apofática, ${ }^{51}$ no sentido de que afirmamos que o acontecimento do Real destitui cada sentido presente na narrativa, negando o registro positivo, e também definitivo, da palavra para cada expressão do pensar. Ela destitui aquela experiência emocional impaciente, que pretende encontrar uma determinação final, uma "causa" primeira, e o sentido ou conteúdo positivo da narrativa. Estivemos procurando demonstrar que, por meio do ponto ausente, do centro vazio ou do quarto ao lado - todas as formulações que procuram falar desse aspecto invisível e ausente da experiência emocional -, há uma recusa do pensamento em relação às formulações positivas das proposições que definem o Real e também àquelas que seriam negativas, que, muito embora não o definam, acabam por deixá-lo simplesmente insaturado, não desenvolvido e não

\footnotetext{
${ }^{51}$ O apofático é a nomeação do movimento de alcance ao transcendente, ao divino, pela negação. Em cada nomeação do divino, há simultaneamente sua negação, o que corresponde, em última análise, à experiência do divino não como objeto, não como outro, mas como abismo ou como nada. Surge, assim, na tradição cristã da teologia negativa, o Deus vazio, que recusa, portanto, de Deus, qualquer predicado, por entender que essa realidade transcendente excede as possibilidades de linguagem. Derrida (1995) discute pormenorizadamente essa questão em seu livro Salvo o nome, mostrando a influência dessa tradição no pensamento contemporâneo.
} 
formulado. A experiência com o Real, seja pela negação do seu sentido, seja pelo excedente do ponto ausente não desenvolvido de cada proposição ou narrativa dos fatos clínicos psicanalíticos, revela-nos que ele escapa somente quando é formulado ou quando um ente ou uma experiência emocional é formulado. Assim, quando o Real não é formulado, ele não tem a possibilidade de escapar e, assim, de aparecer como esse aspecto inominável ausente - que deve se manter, no entanto, de algum modo, presente na narrativa; ou seja, sem a formulação de uma proposição, ele não é vislumbrado.

Nessa formulação, há, simultaneamente, um acontecimento que destitui seu sentido pretérito e nisso reside sua caracterização apofática: o Real - como o impossível - não está em nenhuma parte em que há uma nomeação, embora persista como ausência não entificada, uma persistência que necessita de alguma forma de figuração. Podemos dizer que o próprio movimento da narrativa é o de jamais poder alcançar isso que está justamente fora de nosso alcance, esse impossível. Embora a narrativa possa sempre presenciá-lo e testemunhar sua presença ausente, ela jamais o atinge e jamais o determina, sendo, ao contrário, determinada, ao ser desfeita sucessivamente por ele, que tenta progressivamente atingi-la. Blanchot (2007) pensava de modo muito semelhante a propósito da conversação:

O que está presente nessa presença de fala, tão logo ela se afirma, é precisamente aquilo que não se deixa nunca ver nem alcançar: algo está lá que está fora de alcance (tanto daquele que diz quanto daquele que o escuta); isto está entre nós, mantém-se entre, e a conversa é a abordagem a partir deste meio-termo, distância irredutível que é necessário preservar caso se queira manter a relação com o desconhecido que é o dom único da fala. (p. 197).

Com essa passagem, o autor revela-nos que aquilo que não cessa de não se escrever, como o desconhecido jamais figurado e jamais revelado de uma interlocução, parece ser justamente aquilo que oferece a possibilidade de situarmo-nos "entre" o impossível, a uma distância intermediária em que se conserva e se preserva a visão disso que não se escreve, 
mas que é, paradoxalmente, o próprio dom da fala (ou da narrativa). Aquilo que está presente na narrativa é o desconhecido que não se alcança e que põe em movimento a interlocução e a história. Para o analista, há uma atividade de leitura sem registro, a qual significa ler o que não é escrito e poder presenciar, na não escritura, a leitura do que não existe, como o impossível presente na escrita contingente, na narrativa.

Na negação apofática, no entanto, há simultaneamente o aparecimento, além do desconhecido que não se escreve, daquilo que não pode (ainda) se escrever: o impensável que emerge desse impossível. Com a negação da preposição e a percepção de que nada, nenhum ente, é o próprio Real, percebemos que há na experiência da escrita a manutenção da presença do desconhecido, daquilo que "há", mesmo após toda negação do ente. Nessa "existência" que não “existe” (Levinas, 1997), sobrevêm a estranheza com o ente e, também, um estado de admiração gratuita, pelo aparecimento da alteridade naquilo que parecia ser conhecido até então. Essa estranheza, expressão da alteridade/diferença, pode ser o prenúncio da escuta da reivindicação de uma nova palavra, que surge como uma transfiguração da realidade outrora cotidiana, por conta de sua expansão, da sua possibilidade de ampliar o horizonte de apreensão da realidade psíquica. Ou seja, após toda negação apofática e após a visitação do Real, por meio de sua força de destituição, parece sobrevir na escrita a iluminação inesperada de uma nova palavra, agora uma palavra quebrada, furada e rompida, que abriga justamente seu aspecto negativo, que é a sua abertura ao indeterminado e ao ainda não pensado. Ela surge como uma palavra poética que irrompe, revelando a alteridade de sua obra aberta, uma interminável obra que é, acima de tudo, a possibilidade de nosso vir a ser aquilo que se é, um outro do eu mesmo, a alteridade radical da mesmidade, expressão de sua universalidade: sermos tornados outro que não nosso eu mesmo, nossa alteridade negativa. Tornamo-nos a experiência de sermos realizados por nossa "divindade", nosso Real, que nos torna aquele que vislumbra vestígios inaparentes do impossível e se deixa destituir por esse ponto ausente da 
narrativa, que, assim, não se esgota e que, por essa abertura ao indeterminado, desfaz-nos daquilo que tínhamos como um saber de nós mesmos passado, dos nomes, das palavras conhecidas, abrindo-nos para a experiência presente do que (ainda) não pode se escrever como um registro que rompe o profundo silêncio do impossível; em outras palavras: daquilo que não podemos ainda nos tornar.

\section{0 que Cessa o que Não se Escreve}

Descrevemos, neste trabalho, dois registros do impossível: o Real como $\left(1^{\circ}\right)$ aquele registro de ausência de formas e de sentido do que não cessa de não se escrever e $\left(2^{\circ}\right)$ aquele registro da realidade dos objetos reais: objetos duros, impossibilitados de serem lançados na direção de um novo sentido ou na reelaboração de seu sentido pretérito, pela destituição daquilo que já estava dado como possibilidade. Trata-se, nesse segundo registro do impossível, de um fechamento e tamponamento da abertura ao que não cessa de não se escrever ou de uma tentativa de tornar a mente impossibilitada de pensar e de sentir. A função desobjetalizante, tal como nos aponta Green (1993/2010), nesse caso é dirigida especialmente à ausência, à não coisa (no-thing), e, com essa ação, desfaz-se o movimento de atribuição de sentido - o que não cessa de se escrever, autônomo e heterogêneo -, uma vez que sua função alienante sobre o Real tornou-se desnecessária. Trata-se, ao que parece, de uma conduta tipicamente esquizoide, com atuações e ataques ao estabelecimento da castração. O que cessa o que não se escreve é um registro impossível, por tratar-se da ausência de reconhecimento do Real, o que equivale, na experiência, a uma impossibilidade de relacionar-se com o outro, no sentido da experiência com a alteridade por meio da diferença ontológica.

Com a cessação do que não cessa de não se escrever, há a criação autocrática de uma realidade desprovida de mudança e de transformação. Nessa cessação, interrompe-se o fluxo 
do pensar e da experiência emocional, como uma apreensão de nossa abertura ao desconhecido. Trata-se de uma cessação, em última instância, também impossível, visto que a preponderância de objetos puramente reais - repletos de um sentido fixo e imutável - é a manifestação da destruição da capacidade de pensar e de sentir a partir de uma experiência de castração, ou seja, da experiência da verdade que não é toda e da presença daquilo que ocorre além de nossa visão e que se encontra para além de nós, no "quarto ao lado", fonte de imaginações incompletas e de pressuposições intermináveis. O que cessa o que não se escreve trata-se de uma atividade que encontra na memória e no desejo a produção de concepções que procuram se estabelecer como verdades absolutas e que, na verdade, são defesas contra a iminência daquilo que não cessa de não se escrever e que, de algum modo, foi experimentado precocemente e intolerado radicalmente.

\section{O Que Não Pode (ainda) se Escrever}

Nietzsche (1885/1994b), em Assim falou Zaratustra, em uma poética passagem, como inúmeras desse precioso livro, oferece-nos a seguinte descrição: "Zaratustra tornou a silenciar e pôs-se a escuta. Ouviu, então, um longo, longo grito, que os precipícios lançavam um para o outro e passavam adiante, porque nenhum deles queria guardá-lo; tão sinistro ecoava." (p. 245). Após lermos essa passagem, podemos nos espantar: quantos gritos parecem ecoar silenciosamente no sem-fim da noite do mundo! E, não sendo acolhidos, não se tornando palavras, escritas ou sentidos, vagueiam sem serem nascidos e sem penetrar nas aberturas do nosso pensar, que permanecem fechadas para eles! O pensar do futuro, do futuro de uma análise, é aquele que põe em devir, pela escuta da ausência, esses gritos inaudíveis do semfim. Gritos que, ao se colocarem em devir, podem ser testemunhados pela experiência emocional humana e se tornar, de um modo transformado, parte de nossa teia palimpséstica, 
alterada por novos fios e por novos nós; estamos pensando em uma radical transformação humana: na transformação do impossível Real em algo que seja primeiramente possível e posteriormente necessário. Trakl (1992), que escreveu os versos a seguir, parece que pressentia sermos assombrosamente atravessados pela noite interminável do mundo:

No escuro espelho de minh'alma

Há imagens de mares nunca sentidos. (p. 21). ${ }^{52}$

Nesse escuro espelho, que talvez reflita a escuridão inóspita do Real, de um Real que parece existir na alma, "dentro" de nós, há também tudo aquilo que não pode ainda se tornar palavra, pensamento ou imagem; são "mares nunca sentidos". Esses mares nunca sentidos são os gritos inaudíveis que jamais se tornaram imagens ou sensações e, como algo que "há", jamais se tornaram também parte de um sonho; são o que não pode ainda se escrever, mas que tende a se tornar eventualmente, e de modo transformado e figurado, parte daquilo que não cessa de se escrever. O que não pode (ainda) se escrever é o possível, aquilo que irá ainda poder tornar-se parte do necessário para recobrir, pela ilusão dissimuladora, o Real.

Ogden (2010) cita alguns versos de Robert Frost para ilustrar justamente esse papel da psicanálise, que, em suas palavras, é uma atividade em que

paciente e analista engajam-se em uma experiência, nos termos da situação psicanalítica, desenhada com o objetivo de gerar condições para que o analisando (com participação do analista) possa tornar-se mais capaz de sonhar seus sonhos não sonhados e sonhos interrompidos. (p. 28).

\footnotetext{
${ }^{52}$ Os dois versos são retirados do poema Três sonhos (Drei träume). No original alemão, são eles: “In meiner Seele dunklem Spiegel/ Sind Bilder niegeseh'ner Meere." A tradução de João Barrento, que enfatiza a questão do sentir, foi usada com o propósito de dar maior visibilidade para a questão apresentada, ou seja, que, diante do espelho escuro da alma, há uma diversidade de experiências ou de imagens não apreendidas por nós.
} 
Os versos de Frost citados por Ogden (2010) são os seguintes, que parecem expressar de modo claro para onde deve se dirigir a atenção do analista, como leitor de registros não escritos:

Fiquei imóvel sem o barulho de meus passos

Quando de longe um grito interrompido

Veio, por sobre as casas, de outra rua. (p. 37). ${ }^{53}$

Há, nesses versos, a possibilidade de vislumbrarmos a dimensão de um momento de silêncio e de escuta, por meio desse silêncio, de um grito que está ausente, nesse caso, um grito interrompido, um grito que parece ter sido abafado, emudecido, silenciado, de tal modo que o ar, carregado, ainda pressentiria o seu peso, que permaneceria no ar. No entanto, ele não é escutado, pois simplesmente não existe como grito. Parece ser um grito que, ao se tornar interrompido, sai da esfera do possível, daquilo que poderia estar existindo como possibilidade, para uma mente capaz de gritar. Como analogia gráfica, podemos nos lembrar do quadro $O$ grito, de Edvard Munch (1893); nessa pintura, observamos uma figura humana tapando seus próprios ouvidos. Ela tapa seus ouvidos para não escutar um grito silencioso que ecoa mudo pelo quadro, revelando a experiência da perturbação de quem não quer ouvir um grito que suscita uma dor insuportável. O fundo da tela, com céu e rio instáveis e meneantes, é igual à figura que escuta e se contrasta radicalmente com outras duas figuras humanas ao fundo, aparentemente retilíneas. Estamos, assim, pensando sobre aquilo que não pode (ainda) se escrever como o grito interrompido - ou não mais escutado - que não pode ser sonhado, ou seja, tornado parte do conjunto palimpséstico do psiquismo. As duas figuras humanas que passeiam sobre a ponte aparentemente não escutam esse grito mudo.

\footnotetext{
${ }^{53}$ Os versos foram traduzidos por Daniel Bueno e, no original, dizem: "I have stood still and stopped the sound of feet/ When far away an interrupted cry/ Came over houses from another street."
} 
O analista, nesse sentido, é um leitor daquilo que não foi escrito e - ele mesmo - um escritor. Ler o que não foi escrito é, assim, apresentar os personagens para o a(u)tor (analisando), aqueles personagens que o procuram para a cena para torná-lo encarnado por eles. Ler o que não foi escrito suscita um trabalho de construção, a partir de elementos nunca anteriormente usados ou elementos que, por alguma razão, deixaram de existir como possibilidades. As narrativas clínicas que foram descritas neste trabalho, assim, devem ser compreendidas como desenvolvimentos parciais de pensamentos que, por vezes, apontam justamente para diferentes aspectos do Real que não puderam (ainda) ser pensados e que o leitor poderá ler como um novo escritor, lendo o que não foi escrito e escrevendo - mesmo que silenciosamente e sem uma única linha - aquilo que não pode (ainda) ser escrito pelo autor.

Enquanto o impossível - aquilo que não cessa de não se escrever - mantém uma relação com a narrativa, que é a de restabelecer sua abertura por meio da alteridade/diferença, aquilo que não pode (ainda) se escrever parece ser aquele aspecto não desenvolvido que surge desse impossível, proveniente de um silenciar e de uma escuta do inaudível. Podemos dizer que aquilo que não pode (ainda) se escrever não é uma impossibilidade, no sentido de que não é algo que esteja na esfera de um velamento como condição do desvelado, mas algo que ainda não se desenvolveu e não se transformou em um pensar em virtude das condições mentais do pensador. Há uma relação entre aquilo que não pode nascer e aquele que gesta um pensamento, a qual passa pela possibilidade de tolerância ou de paciência em relação ao impossível. Estamos, assim, observando que o Real parece ter esse duplo aspecto: ser tanto o não desenvolvido, o pensamento não pensado, quanto a pura ausência e negatividade do quarto ao lado impronunciável ou o "vazio e sem formas" que contém todas as qualidades ainda não desenvolvidas. 
Havíamos, outrora, indicado que a cena primária, correlata à triangulação edípica, é justamente a expressão dessa abertura ao impossível e, simultaneamente, a mola propulsora de um movimento interminável da imaginação que não cessa de se escrever em nossa narrativa manifesta. Podemos, agora, acrescentar que é na abertura ao impossível que sobrevém a destituição do mesmo e, somente com essa destituição - que nos mantém na instabilidade de um lugar sem lugar -, uma nova palavra, daquilo que não pode ser escrito, pode ser reivindicada para se tornar existente e passar a ser parte daquilo que não cessa de se escrever em nós, pela transformação que fazemos de um grito silencioso solto no ar e inaudível para formas articuladas inconscientes, em que o grito articula-se com a predominância do princípio do prazer/desprazer, ou seja, não só veste-se de sentido, como passa a recobrir o Real.

\section{Que se Escreve, Um Pouco Mais}

Iremos, agora, discutir um dos aspectos mais intrigantes de nossa escrita, procurando deixar com que ele possa, eventualmente, ser desenvolvido futuramente ou simplesmente apagado, sem deixar vestígios. Trata-se daquilo que se escreve do que não cessa de não se escrever; um registro que parece ser o de uma escrita em que predomina uma fala sem sujeito ou de um sujeito desfeito, de um dizer gratuito de uma palavra instável que acompanha o nascimento de uma reivindicação da linguagem, que rompe o silêncio mudo decorrente da destituição dos nomes e dos sentidos das coisas cotidianas. Trata-se de uma modalidade derradeira, do furado que deixa passar uma palavra mesmo após os nomes terem sido desfeitos. Esse furado, um passador que deixa passar, torna-se aquele que alcançou o consentimento do Real para deixar ser o leitor daquilo que ele escreve, como quem se lê 
distinto de quem se escreve e, no entanto, unido na estranha permissão de consentir essa passagem que rompe o silêncio e a mudez das coisas. ${ }^{54}$

São inúmeras as descrições desse registro na literatura, mas é menos frequente encontrarmos na psicanálise. Barrento (1986), por exemplo, ao comentar o poema de Michel Krüger, O lago, fala-nos: "Falo de uma estética do olhar, e dos nós do real em que ainda se escondem as verdades possíveis, falo de restos, de fragmentos, de vestígios, de um apagar de nomes para que os objetos falem. De margens, da água e da sua força, de pássaros e das suas linguagens." (p. 57). O autor descreve um "apagar de nomes" para que os objetos falem. O que se escreve do que não cessa de não se escrever parece ser um registro em que se apagam os nomes, em que os sentidos sem fim das coisas, esses sentidos que são incessantes, que são atribuições tecidas sobre o nada, repentinamente se esgarçam como um velho tecido roto, que se desfaz, carcomido em restos e vestígios de algo que outrora foi; assim, nesse empobrecimento, no esfarrapado, no vestígio do que outrora foi uma tessitura de nós compondo uma estética da rica personalidade sustentada pelas primorosas tecedeiras e rendeiras, que compuseram por fios de imagens e de sonhos esse interminável lugar e morada de alguém, surgem os vestígios do que não é pensável, mas principalmente do não pensado, que surge pelo empobrecimento da palavra; e uma palavra mostra-se. Ela mostra, no esgarçado e furado tecido encobridor do Real, a sua incerteza e instabilidade, que não se refugiam em uma posição determinada. Por se manter pobre, na penúria de sentido, revela-se pela palavra o que é a experiência emocional amigada com a serena paciência que rompe o silêncio das coisas para falar por elas: uma palavra que mostra. O analista, nesse sentido, é

\footnotetext{
${ }^{54}$ Podemos dizer, seguindo nossa linha especulativa pessoal, que o necessário aparece no contingente, por meio de formas dissimuladoras e figurações repetitivas, para recobrir o impossível em seu duplo registro. O impossível é recoberto com formas necessárias para a preservação da contingência, da narrativa humana, de modo que o impossível não se estabeleça nem como possível - novo e pressentido como catastrófico - nem como um registro impossível para a permanência de uma mente regida pela contingência e necessidade. O derradeiro, oriundo da visitação do impossível, tal como escrevemos nesta parte, é nossa última morada: a resistência da linguagem que se diz a partir do impossível, por um passador furado que se escreve mesmo quando não se encontra reconhecido em sua escrita; um homem sem ninguém dentro de si, analista derradeiro, uma clareira que escurece o sentido para iluminar a passagem do impossível pelo possível, como derradeira e fundamental possibilidade.
} 
um leitor de vestígios da origem (Safra, 2006) e do modo como os tecidos e seus nós teceramse sobre ela; mas, também, no empobrecimento pessoal, furado e aberto, mostra.

Nessa palavra que mostra, há a expressão de uma existência por meio da linguagem e não por meio da mesmidade do eu mesmo, que, simultaneamente, é um apontamento para o buraco da existência revelada, para um ente que não é mais unitário e sim revelação de sua negação - ao mesmo tempo -, uma revelação que o põe em articulação com a transitoriedade, com seu fenecimento e com sua universalidade, como "um homem sem ninguém dentro de si mesmo.” (Borges, citado por Ogden, 2010, p. 149).

Por fim, o que se escreve é a tentativa insistente de registro, mesmo onde não há mais possibilidade de se configurar uma narrativa pessoal, talvez porque aí não exista mesmo mais nada que seja pessoal. Assim, vagamos na direção do impossível que nos acossa e vem ao nosso encontro, munidos da palavra que ainda rompe o silêncio, mostrando o mundo na perpétua instabilidade da alteridade/diferença. Gostaríamos, assim, de não acabar, de dizer um pouco mais, e lembrar-nos dos versos de Krüger (1986) e com ele poder dizer:

As últimas palavras saltam como seixos

sobre a água, impressões claras

no pano vibrante sobre o lago.

Não tenho já nome,

afundando também o teu. (p. 15). 


\section{REFERÊNCIAS}

Ab'Sáber, T. A. M. (2005). O sonhar restaurado: formas do sonhar em Bion, Winnicott e Freud. São Paulo: Ed.34.

Alves, D. B. (1997). Agir, alucinar, sonhar. In M. O. A. França, Bion em São Paulo: ressonâncias (pp. 241-251). São Paulo: Sociedade Brasileira de Psicanálise de São Paulo/Imprensa Oficial do Estado.

Assoum, P-L. (1997). O sujeito e o outro em Levinas e Lacan. Cadernos de Subjetividade, 5(1), 27-38.

Akhmátova, A. (2009). Antologia poética (L. M. Coelho, Trad.). Porto Alegre: L\&PM.

Bachelard, G. (1989). A poética do espaço (A. Danesi, Trad.). São Paulo: Martins Fontes. (Trabalho original publicado em 1957).

Badiou, A. (2002). Para uma nova teoria do sujeito (E. Silva, Trad.). Rio de Janeiro: RelumeDumará.

Barbosa, S. D. M. (2000). O outro da razão: a tradição romântica em Georges Bataille. Dissertação de Mestrado, Faculdade de Letras, Universidade do Porto, Porto.

Barrento, J. (1986). Tempo de olhos. In M. Krüger, O Lago (pp. 56-63). Lisboa: Apaginastantas.

Bataille, G. (2003). História do olho (E. R. Moraes, Trad.). São Paulo: Cosac Naify.

Baudrillard, J. (2002). A troca impossível. (C. Lacerda, Trad.). Rio de Janeiro: Nova Fronteira.

Beckett, S. (1976). Esperando Godot (F. Rangel, Trad.). São Paulo: Abril Cultural.

Beckett, S. (2010). Dias felizes (F. S. Andrade, Trad.). São Paulo: Cosacnaify. (Trabalho original publicado em 1961).

Bion, W. R. (1975). Conferências brasileiras I: São Paulo 1973 (P. D. Corrêa, Trad.). Rio de Janeiro: Imago. (Trabalho original publicado em 1974).

Bion, W. R. (1985). Evidência (P. Sandler, Trad.). Revista Bras. Psicanálise, 19(1), 129-141. (Trabalho original publicado em 1976).

Bion, W. R. (1989). Uma memória do futuro I: o sonho (P. Sandler, Trad.). São Paulo: Martins Fontes. (Trabalho original publicado em 1975).

Bion, W. R. (1991a). A atenção e interpretação: o acesso científico à intuição em psicanálise e grupos. Rio de Janeiro: Imago. (Trabalho original publicado em 1970).

Bion, W. R. (1991b). O aprender com a experiência (P. D. Correa, Trad.). Rio de Janeiro: Imago. (Trabalho original publicado em 1962). 
Bion, W. R. (1992). Conversando com Bion: quatro discussões com Bion: Bion em Nova Iorque e em São Paulo (P. Sandler, Trad.). Rio de Janeiro: Imago. (Trabalho original publicado em 1960).

Bion, W. R. (1994a). Sobre alucinação. In W. R. Bion, Estudos psicanalíticos revisados (W. Dantas, Trad.). (pp. 79-100). Rio de Janeiro: Imago. (Trabalho original publicado em 1958).

Bion, W. R. (1994b). Sobre a arrogância. In W. R. Bion, Estudos psicanalíticos revisados (W. Dantas, Trad.). (pp. 101-108). Rio de Janeiro: Imago. (Trabalho original publicado em 1957).

Bion, W. R. (1994c). Uma teoria sobre o pensar. In W. R. Bion, Estudos psicanalíticos revisados (W. Dantas, Trad.). (pp. 127-138). Rio de Janeiro: Imago. (Trabalho original publicado em 1962).

Bion, W. R. (1994d). Comentário. In W. R. Bion, Estudos psicanalíticos revisados (W. Dantas, Trad.). (pp. 139-185). Rio de Janeiro: Imago. (Trabalho original publicado em 1967).

Bion, W. R. (1994e). O gêmeo imaginário. In W. R. Bion, Estudos psicanalíticos revisados (W. Dantas, Trad.). Rio de Janeiro: Imago. (Trabalho original publicado em 1950).

Bion, W. R. (1994f). Ataques à ligação. In W. R. Bion, Estudos psicanalíticos revisados (W. Dantas, Trad.). Rio de Janeiro: Imago. (Trabalho original publicado em 1959).

Bion, W. R. (1994g). Notas sobre a teoria da esquizofrenia. In W. R. Bion, Estudos psicanalíticos revisados (W. Dantas, Trad.). Rio de Janeiro: Imago. (Trabalho original publicado em 1953).

Bion, W. R. (1997). The grid. In W. R. Bion, Taming wild thoughts (pp. 6-24). London: Karnac. (Trabalho original publicado em 1963).

Bion, W. R. (2000a). Notas sobre memória e desejo. In W. R. Bion, Cogitações (P. Sandler, Trad.). (pp. 392-397). Rio de Janeiro: Imago. (Trabalho original publicado em 1967).

Bion, W. R. (2000b). Técnica analítica. In W. R. Bion, Cogitações (P. Sandler, Trad.). (pp.174). Rio de Janeiro: Imago. (Trabalho original publicado em 1960).

Bion, W. R. (2004a). Transformações: do aprendizado ao crescimento (P. C. Sandler, Trad.). Rio de Janeiro: Imago. (Trabalho original publicado em 1965).

Bion, W. R. (2004b). Elementos de psicanálise (P. Sandler, Trad.). Rio de Janeiro: Imago. (Trabalho original publicado em 1963).

Bion, W. R. (2011). Taming wild thoughts. London, England: Karnac Books. (Trabalho original publicado em 1997).

Birksted-Breen, D. (2005). Tempo e après-coup. In R. D. Medina Ponce, Livro anual de psicanálise (Vol. 19, pp. 219-230). São Paulo: Escuta.

Blake, W. (1984). Escritos de Willian Blake (A. Mascariano, Trad.). Porto Alegre: L\&PM.

Blanchot, M. (2007). A conversa infinita - A experiência limite (J. Moura Jr., Trad.). São Paulo: Escuta. 
Briton, R. (2003). O outro quarto e o espaço poético. In R. Briton, Crença e Imaginação (E. M. R. Barros, Trad.). (pp. 175-185). Rio de Janeiro: Imago.

Caper, R. (2002). Tendo mente própria: uma visão kleineana do self e do objeto. Rio de Janeiro: Imago.

Castelo Filho, C. (2009). Os (des)caminhos de Édipo: a resposta é o infortúnio da pergunta. Jornal de Psicanálise, 42(77), 243-254.

Derrida, J. (1995). Salvo o nome (N. A. Donatti, Trad.). Campinas, SP: Papirus.

Dostoiévski, F. M. (1970). Os irmãos Karamazov. Rio de Janeiro: Abril Cultural. (Trabalho original publicado em 1879).

Eliot, T. S. (1981). Poesia (I. Junqueira, Trad.). Rio de Janeiro: Nova Fronteira.

Ferro, A. (2003). O pensamento clínico de Antonino Ferro: conferências e seminários (M. Petricciani, Trad.). São Paulo: Casa do Psicólogo.

Figueiredo, L. C. (1994). Fala e acontecimento em análise. In L. C. Figueiredo, Escutar, recordar, dizer: encontros heideggerianos com a clínica psicanalítica (pp. 149-169). São Paulo: Educ/Escuta.

Figueiredo, L. C. (1995). Heidegger, língua e fala. Psicanálise e Universidade, 3, 67-75.

Figueiredo, L. C. (1997). O interesse de Levinas para a psicanálise: desinteresse do rosto. Cadernos de Subjetividade, 5(1), 39-51.

Figueiredo, L. C., Tamburrino, G., \& Ribeiro, M. (2011). Bion em nove lições: lendo Transformações. São Paulo: Escuta.

Freud, S. (2006a). Uma nota sobre o inconsciente na psicanálise. In S. Freud, Edição standard brasileira das obras psicológicas completas de Sigmund Freud (J. Salomão, Trad., Vol. XII, pp. 273-285). Rio de Janeiro: Imago. (Trabalho original publicado em 1912).

Freud, S. (2006b). A interpretação dos sonhos. In S. Freud, Edição standard brasileira das obras psicológicas completas de Sigmund Freud (J. Salomão, Trad., Vol. IV-V, pp. 39-649). Rio de Janeiro: Imago. (Trabalho original publicado em 1900).

Freud, S. (2006c). O mal-estar na civilização. In S. Freud, Edição standard brasileira das obras psicológicas completas de Sigmund Freud (J. Salomão, Trad., Vol. XXI, pp. 67-148). Rio de Janeiro: Imago. (Trabalho original publicado em 1930).

Freud, S. (2006d). Novas conferências introdutórias sobre psicanálise. In S. Freud, Edição standard brasileira das obras psicológicas completas de Sigmund Freud (J. Salomão, Trad., Vol. XXII, pp. 13-177). Rio de Janeiro: Imago. (Trabalho original publicado em 1933).

Freud, S. (2006e). Além do princípio do prazer. In S. Freud, Edição standard brasileira das obras psicológicas completas de Sigmund Freud (J. Salomão, Trad., Vol. XVIII, pp. 13-75). Rio de Janeiro: Imago. (Trabalho original publicado em 1920). 
Freud, S. (2006f). História do movimento psicanalítico. In S. Freud, Edição standard brasileira das obras psicológicas completas de Sigmund Freud (J. Salomão, Trad., Vol. XIV, pp. 15-73). Rio de Janeiro: Imago. (Trabalho original publicado em 1914).

Freud, S. (2006g). Projeto para uma psicologia científica. In S. Freud, Edição standard brasileira das obras psicológicas completas de Sigmund Freud (J. Salomão, Trad., Vol. I, pp. 335-454). Rio de Janeiro: Imago. (Trabalho original publicado em 1895).

Freud, S. (2006h). Esboço de psicanálise. In S. Freud, Edição standard brasileira das obras psicológicas completas de Sigmund Freud (J. Salomão, Trad., Vol. XXIII, pp. 153-221). Rio de Janeiro: Imago. (Trabalho original publicado em 1940).

Freud, S. (2006i). Recomendação aos médicos que exercem a psicanálise. In S. Freud, Edição standard brasileira das obras psicológicas completas de Sigmund Freud (J. Salomão, Trad., Vol. XII, pp. 123-133). Rio de Janeiro: Imago. (Trabalho original publicado em 1912).

Freud, S. (2006j). Construções em análise. In S. Freud, Edição standard brasileira das obras psicológicas completas de Sigmund Freud (J. Salomão, Trad., Vol. XXIII, pp. 275-287). Rio de Janeiro: Imago. (Trabalho original publicado em 1937).

Freud, S. (2006k). O inconsciente. In S. Freud, Edição standard brasileira das obras psicológicas completas de Sigmund Freud (J. Salomão, Trad., Vol. XIV, pp. 165-222). Rio de Janeiro: Imago. (Trabalho original publicado em 1915).

Freud, S. (20061). O estranho. In S. Freud, Edição standard brasileira das obras psicológicas completas de Sigmund Freud (J. Salomão, Trad., Vol. XVII, pp. 235-269). Rio de Janeiro: Imago. (Trabalho original publicado em 1919).

Freud, S. (2006m). Inibições, sintoma e ansiedade. In S. Freud, Edição standard brasileira das obras psicológicas completas de Sigmund Freud (J. Salomão, Trad., Vol. XX, pp. 81171). Rio de Janeiro: Imago. (Trabalho original publicado em 1926).

Freud, S. (2006n). Psicanálise. In S. Freud, Edição standard brasileira das obras psicológicas completas de Sigmund Freud (J. Salomão, Trad., Vol. XX, pp. 251-259). Rio de Janeiro: Imago. (Trabalho original publicado em 1926).

Freud, S. (2006o). Notas sobre um caso de neurose obsessiva (o homem dos ratos). In S. Freud, Edição standard brasileira das obras psicológicas completas de Sigmund Freud (J. Salomão, Trad., Vol. X, pp. 137-273). Rio de Janeiro: Imago. (Trabalho original publicado em 1909).

Freud, S. (2006p). Totem e tabu. In S. Freud, Edição standard brasileira das obras psicológicas completas de Sigmund Freud (J. Salomão, Trad., Vol. XIII, pp. 21-162). Rio de Janeiro: Imago. (Trabalho original publicado em 1913).

Freud, S. (2006q). História de uma neurose infantil. In S. Freud, Edição standard brasileira das obras psicológicas completas de Sigmund Freud (J. Salomão, Trad., Vol. XVII, pp. 19128). Rio de Janeiro: Imago. (Trabalho original publicado em 1918).

Freud, S. (2006r). O ego e o id. In S. Freud, Edição standard brasileira das obras psicológicas completas de Sigmund Freud (J. Salomão, Trad., Vol. XIX, pp. 15-80). Rio de Janeiro: Imago. (Trabalho original publicado em 1923). 
Freud, S. (2006s). Formulações sobre os dois princípios do funcionamento mental. In S. Freud, Edição standard brasileira das obras psicológicas completas de Sigmund Freud (J. Salomão, Trad., Vol. XII, pp. 233-244). Rio de Janeiro: Imago. (Trabalho original publicado em 1911).

Freud, S. (2006t). Estudos sobre a histeria. In S. Freud, Edição standard brasileira das obras psicológicas completas de Sigmund Freud (J. Salomão, Trad., Vol. II, pp. 13-320). Rio de Janeiro: Imago. (Trabalho original publicado em 1893).

Freud, S. (2006u). A perda da realidade na neurose e na psicose. In S. Freud, Edição standard brasileira das obras psicológicas completas de Sigmund Freud (J. Salomão, Trad., Vol. XIX, pp. 203-212). Rio de Janeiro: Imago. (Trabalho original publicado em 1924).

Freud, S. (2006v). Delírios e sonhos na Gradiva de Jensen. In S. Freud, Edição standard brasileira das obras psicológicas completas de Sigmund Freud (J. Salomão, Trad., Vol. IX, pp. 19-89). Rio de Janeiro: Imago. (Trabalho original publicado em 1907).

Freud, S. (2006x). Sobre a psicopatologia da vida cotidiana. In S. Freud, Edição standard brasileira das obras psicológicas completas de Sigmund Freud (J. Salomão, Trad., Vol. VI, pp. 19-272). Rio de Janeiro: Imago. (Trabalho original publicado em 1901).

Garcia-Rosa, L. A. (2007). Freud e o inconsciente. Rio de Janeiro: Jorge Zahar.

Gianesi, A. P. L. (2011). Causalidade e desencadeamento na clínica psicanalítica. São Paulo: Annablume.

Giovannetti, M. F. (1997). Uma questão hamletiana. In M. O. A. França, Bion em São Paulo: ressonâncias (pp. 263-274). São Paulo: Sociedade Brasileira de Psicanálise de São Paulo/Imprensa Oficial do Estado.

Green, A. (2010). O trabalho do negativo (F. Murad, Trad.). São Paulo: Artmed. (Trabalho original publicado em 1993).

Grimberg, L., Sor, D., \& Bianchedi, E. (1973). Introdução às idéias de Bion (T. O. Brito, Trad.). São Paulo: Imago.

Grotstein, J. S. (2003). Quem é o sonhador que sonha o sonho?: um estudo de presenças psíquicas. Rio de Janeiro: Imago.

Grotstein, J. S. (2010). Um facho de intensa escuridão: o legado de Winfred Bion à psicanálise. Porto Alegre: Artmed.

Habermas, J. (1998). O discurso filosófico da modernidade. Lisboa, Portugal: Don Quixote.

Heidegger, M. (1984a). Sobre a essência da verdade (E. Stein, Trad., Os Pensadores). São Paulo: Abril Cultural. (Trabalho original publicado em 1930).

Heidegger, M. (1984b). Sobre o humanismo (E. Stein, Trad., Os Pensadores). São Paulo: Abril Cultural. (Trabalho original publicado em 1949).

Heidegger, M. (1988). A essência do fundamento. Lisboa, Portugal: Edições 70. (Trabalho original publicado em 1949). 
Heidegger, M. (1997). El ser y el tiempo (J. Gaos, Trad.). México: Fondo de Cultura Econômica. (Trabalho original publicado em 1927).

Heidegger, M. (1998). La época de la imagen del mundo. In M. Heidegger, Caminos de bosque (H. Cortés \& A. Leyte, Trad.). (pp. 63-90). Madrid, Espanha: Alianza Editorial. (Trabalho original publicado em 1938).

Heidegger, M. (1999). Le príncipe de raison (A. Préau, Trad.). Saint-Amand, France: Galimard. (Trabalho original publicado em 1962).

Heidegger, M. (2004). A essência da linguagem. In M. Heidegger, A caminho da linguagem (M. S. Cavalcanti, Trad.). (pp. 121-171). Petrópolis, RJ: Vozes. (Trabalho original publicado em 1959).

Heidegger, M. (2006). Ensaios e conferências (E. C. Leão, Trad.). Petrópolis, RJ: Vozes. (Trabalho original publicado em 1954).

Hesse, H. (1972). Peter Camenzind (M. M. Spiritus, Trad.). São Paulo: Brasiliense. (Trabalho original publicado em 1903).

Hölderlin, F. (1991). Poemas (P. Quintela, Trad.). Lisboa, Portugal: Relógio D’Água. (Trabalho original publicado em 1800).

Horkheimer, M. (2002). Eclipse da razão. São Paulo: Centauro. (Trabalho original publicado em 1955).

Houaiss, A. (2009). Dicionário Houaiss da língua portuguesa. Rio de Janeiro: Objetiva.

Kafka, F. (1993). Contos, fábulas e aforismos (E. Silveira, Trad.). Rio de Janeiro: Civilização Brasileira.

Kancyper, L. (2008). O papel de fatores pré-edípicos e edípicos na vida psíquica. In R. D. Medina Ponce, Livro anual de psicanálise (Vol. 22, pp. 237-251). São Paulo: Escuta.

Kant, I. (1994). Prefácio da segunda edição. In I. Kant, Crítica da razão pura (pp. 15-35). Lisboa, Portugal: Fundação Calouste Gulbenkian. (Trabalho original publicado em 1787).

Khan, M. M. R. (1991). Quando a primavera chegar (C. S. Bacchi, Trad.). São Paulo: Escuta.

Klein, M. (1975). O sentimento de solidão: nosso mundo adulto e outros ensaios (P. D. Correa, Trad.). Rio de Janeiro: Imago. (Trabalho original publicado em 1963).

Klein, M. (2006). Notas sobre alguns mecanismos esquizóides. In M. Klein, Obras completas de Melanie Klein (pp. 17-43). Rio de Janeiro: Imago. (Trabalho original publicado em 1946).

Krüger, M. (1986). O lago (J. Barrento, Trad.). Lisboa: Apaginastantas.

Lacan, J. (1985a). O seminário: livro XI: os quatro conceitos fundamentais da psicanálise. Rio de Janeiro: Jorge Zahar. (Trabalho original publicado em 1964).

Lacan, J. (1985b). O seminário: livro XX: mais, ainda. Rio de Janeiro: Jorge Zahar. (Trabalho original publicado em 1972). 
Lacan, J. (1992). O seminário, livro VIII - A transferência. Rio de Janeiro: Jorge Zahar. (Trabalho original publicado em 1991).

Laplanche, J., \& Pontalis, J. B. (2004). Vocabulário da psicanálise. São Paulo: Martins Fontes.

Lawrence, D. H. (1991). Alguma poesia (A. O. Gomes, Trad., Seleção Bilíngue). São Paulo: T. A. Queiroz.

Leclaire, S. (1992). O país do outro: o inconsciente (C. Marques, Trad.). Rio de Janeiro: Jorge Zahar.

Levinas, E. (1988). Totalidade e infinito. Lisboa, Portugal: Edições 70. (Trabalho original publicado em 1980).

Levinas, E. (1993). Humanismo do outro homem. Petrópolis, RJ: Vozes.

Levinas, E. (1997). Entrevista a Phillipe Nemo \& François Poirié. Cadernos de Subjetividade, $5(1), 7-26$.

Lopez-Corvo, R. E. (2003). The dictionary of the work of W. R. Bion. London, England: Karnac.

Matte-Blanco, I. (1998). The unconscious as infinite sets: an essay in bi-logic. London, England: Karnac. (Trabalho original publicado em 1975).

McDougall, J. (1991). Teatros do corpo: o psicossoma em psicanálise. São Paulo: Martins Fontes.

Meltzer, D. (1998). O significado clínico da obra de Bion. São Paulo: Escuta.

Miller, J. H. (1995). A ética da leitura: ensaios 1979-1989. Rio de Janeiro: Imago.

Moraes, E. R. (2003). Um olho sem rosto. In G. Bataille, História do olho (pp. 7-20). São Paulo: Cosac Naify.

Nabokov, V. (1996). Perfeição e outros contos (J. Dauster, Trad.). São Paulo: Companhia das Letras.

Nietzsche, F. (1978a). A gaia ciência (R. R. Torres Filho, Trad., Os Pensadores). São Paulo: Abril Cultural. (Trabalho original publicado em 1882).

Nietzsche, F. (1978b). Sobre verdade e mentira no sentido extra-moral (R. R. Torres Filho, Trad., Os Pensadores). São Paulo: Abril Cultural. (Trabalho original publicado em 1873).

Nietzsche, F. (1978c). O anticristo (R. R. Torres Filho, Trad., Os Pensadores). São Paulo: Abril Cultural. (Trabalho original publicado em 1888).

Nietzsche, F. (1994a). A origem da tragédia (A. Ribeiro, Trad.). Lisboa, Portugal: Guimarães Editores. (Trabalho original publicado em 1892).

Nietzsche, F. (1994b). Assim falou Zaratustra (M. da Silva, Trad.). Rio de Janeiro: Bertrand Brasil. (Trabalho original publicado em 1885). 
Nunes, B. (1992). Passagem para o poético: filosofia e poesia em Heidegger. São Paulo: Ática.

O’Shaughnessy, E. (1994). O que é um fato clínico? In R. D. Medina Ponce, Livro anual de psicanálise (Vol. 10, pp. 23-32). São Paulo: Escuta.

Ogden, T. (1996a). Os sujeitos da psicanálise. São Paulo: Casa do Psicólogo.

Ogden, T. (1996b). Reconsidering three aspects of psychoanalitic technique. Internacional Journal of Psycho-Analysis, 77, 883-899.

Ogden, T. (2010). Esta arte da psicanálise: sonhando sonhos não sonhados e gritos interrompidos (D. Bueno, Trad.). Porto Alegre: Artmed.

Parente, A. M. (2011) Aura das Palavras. Rev. Ide, 34(52), 247-259.

Pascal, B. (1957). Pensamentos (S. Milliet, Trad.). São Paulo: Difusão Europeia do Livro. (Trabalho original publicado em 1670).

Pessanha, J. G. (2000). Ignorância do sempre. São Paulo: Ateliê Editorial.

Philips, F. J. (1987). Entrevista. Rev. Ide, 14(1), 10-17.

Pirandello, L. (1981). Seis personagens à procura de um autor (M. da Silva, Trad.). São Paulo: Abril Cultural. (Trabalho original publicado em 1921).

Poe, E. A. (1978). A carta roubada. In E. A. Poe, Histórias extraordinárias. São Paulo: Abril Cultural. (Trabalho original publicado em 1848).

Priel, B. (2005). Interpretações psicanalíticas: palavra-música e tradução. In R. D. Medina Ponce, Livro anual de psicanálise (Vol. 19, pp. 245-255). São Paulo: Escuta.

Rascovsky, A. \& Rascovsky, M. (1968). On the genesis of acting out and psychopathic behaviour in Sophocles's Oedipus. International Journal of Psycho-Analysis, (49), 390-395.

Rayner, E. (1990). Experiências infinitas: uma abordagem da contribuição de Matte-Blanco à teoria psicanalítica. Rev. Bras. Psicanal., 24(1), 59-74.

Ricoeur, P. (2010). Escritos e conferências 1: em torno da psicanálise (E. Bini, Trad.). São Paulo: Loyola.

Rosenfeld, H. (1988). Impasse e interpretação: fatores terapêuticos e antiterapêuticos no tratamento psicanalítico de pacientes neuróticos, psicóticos e fronteiriços (A. M. Rosas, Trad.). Rio de Janeiro: Imago.

Safatle, V. (2009). Uma clínica do sensível: a respeito da relação entre destituição subjetiva $e$ primado do objeto. Recuperado em 25 de maio, 2011, de http://pt.scribd.com/doc/ 19133286/ Vladimir-Safatle-Destituicao-subjetiva-e-primado-do-objeto.

Safra, G. (2004). A pó-ética na clínica contemporânea. Aparecida, SP: Idéias e Letras.

Safra, G. (2005). A face estética do self: teoria e clínica. Aparecida, SP: Idéias e Letras. 
Safra, G. (2006). Hermenêutica na clínica contemporânea. São Paulo: Sobornost.

Safra, G. (2007). O real na situação clínica (Curso ministrado no Programa de PósGraduação em Psicologia do Departamento de Psicologia Clínica da Universidade de São Paulo).

Safra, G. (2010). Investigação psicanalítica de experiências de self: a religiosidade, a espiritualidade, o sagrado e o místico. (Curso ministrado no Programa de Pós-Graduação em Psicologia Clínica da Universidade de São Paulo).

Safranski, R. (2000). Heidegger: um mestre da Alemanha entre o bem e o mal (L. Luft, Trad.). São Paulo: Geração Editorial.

Sandler, P. C. (2005a). The language of Bion: a dictionary of concepts. London, England: Karnac Books.

Sandler, P. C. (2005b). Patologias narcísicas e alteridade. Rev. Bras. Psicanálise, 39(3), 35 46.

Sandler, P. C. (2008). Freie Einfälle: a irrupção verbal do desconhecido. Rev. Bras. Psicanálise, 42(2), 43-57.

Silva, J. R. O. (2001). Considerações sobre o conto "O Terror" de Vladimir Nabokov por uma perspectiva heideggeriana. Rev. Psicologia USP, 12(1), 33-48.

Simanke, R. T. (1994). A formação da teoria freudiana das psicoses. Rio de Janeiro: 34.

Stevens, W. (1950). A primitive like an orbe. Recuperado em 12 de dezembro, 2010, de http://www.likeanorb.com/aprimitivelikeanorb.html.

Symington, J., \& Symington, N. (1996). The clinical thinking of Wilfred Bion. London, England: Routledge.

Szymborska, W. (2011). Poemas (R. Przybycien, Trad.). São Paulo: Companhia das Letras.

Tagore, R. (1912). Gitanjali verse \#60. Recuperado em 10 de novembro, 2010, de http://www.wisdomportal.com/PoetryAnthology/Tagore-Anthology.html.

Tagore, R. (1950). O jardineiro (G. Almeida, Trad.). São Paulo: José Olympio. (Trabalho original publicado em 1913).

Tálamo, P. B. (1997). Os dois lados da cesura. In M. O. A. França (Org.), Bion em São Paulo: ressonâncias (Coleção Acervo Psicanalítico, pp. 377-396). São Paulo: Sociedade Brasileira de Psicanálise de São Paulo.

Trakl, G. (1992). Outono transfigurado (J. Barrento, Trad.). Lisboa: Assírio\&Alvim.

Trinca, W. (1998). A arte interior do psicanalista. São Paulo: EPU/EDUSP.

Tuan, Y. (2005). Paisagens do medo (L. Oliveira, Trad.). São Paulo: Unesp.

Ungaretti, G. (2003). A alegria (G. H. Cavalcanti, Trad.). Rio de Janeiro: Record. (Trabalho original publicado em 1914-1919). 
Vaz, L. H. (1993). Escritos de filosofia II: ética e cultura. São Paulo: Loyola.

Vernant, J-P. (2000). O universo, os deuses, os homens: mitos gregos contados por JeanPierre Vernant (R. F. D’Aguiar, Trad.). São Paulo: Companhia das Letras.

Whitman, W. (1983). Leaves of grass (G. Campos, Trad.). São Paulo: Brasiliense. (Trabalho original publicado em 1855).

Winnicott, D. W. (1975). O brincar e a realidade. Rio de Janeiro: Imago. (Trabalho original publicado em 1971).

Winnicott, D. W. (1982a). A capacidade para estar só. In D. W. Winnicott, O ambiente e os processos de maturação (I. Ortiz, Trad.). (pp. 31-37). Porto Alegre: Artes Médicas. (Trabalho original publicado em 1958).

Winnicott, D. W. (1982b). Comunicação e falta de comunicação levando ao estudo de certos opostos. In D. W. Winnicott, O ambiente e os processos de maturação (I. Ortiz, Trad.). (pp. 163-174). Porto Alegre: Artes Médicas. (Trabalho original publicado em 1963).

Winnicott, D. W. (1982c). Sobre a contribuição da observação direta da criança para a psicanálise. In D. W. Winnicott, O ambiente e os processos de maturação (I. Ortiz, Trad.). Porto Alegre: Artes Médicas. (Trabalho original publicado em 1957).

Winnicott, D. W. (1984). Consultas terapêuticas em psiquiatria infantil (J. M. X. Cunha, Trad.). Rio de Janeiro: Imago. (Trabalho original publicado em 1971).

Winnicott, D. W. (1990). A natureza humana (D. L. Bogomoletz, Trad.). Rio de Janeiro: Imago. (Trabalho original publicado em 1988). 